AN INTRODUCTION TO THE LAW OF AFGHANISTAN

Stanford

LawSchool 


\title{
An Introduction to the
}

Law of Afghanistan

\author{
Third Edition
}

Afghanistan Legal Education Project (ALEP)

at Stanford Law School

http://alep.stanford.edu

afghanistanlegaleducation@gmail.com

Stanford Law School

Crown Quadrangle

559 Nathan Abbott Way

Stanford, CA 94305-8610

www.law.stanford.edu

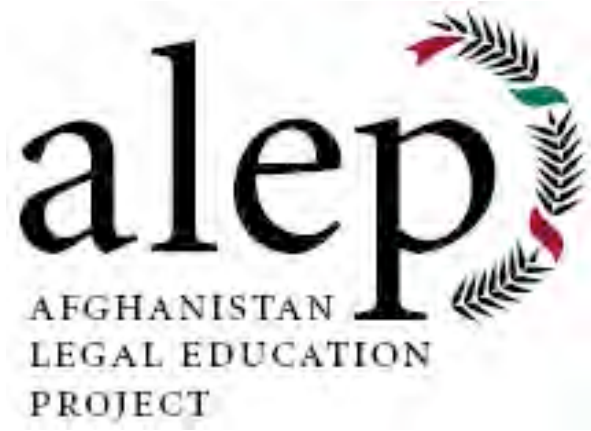




$$
\text { pe }
$$




\section{ALEP - STANFORD LAW SCHOOL}

\section{Authors}

Eli Sugarman (Co-Founder, Student Co-Director, 2007-09) Alexander Benard (Co-Founder, Student Co-Director, 2007-09)

Anne Stephens Lloyd (Student Co-Director, 2008-09)

Ben Joseloff (Post-Doctoral Fellow at AUAF, 2008)

Max Rettig (Student Co-Director, 2009-10)

Stephanie Ahmad (Rule of Law Fellow, 2011-12)

Jason Berg

Editors

Morgan Galland (Student Director, 2010-11)

Rose Leda Ehler (Student Co-Director, 2011-12)

Daniel Lewis (Student Co-Director, 2011-12)

Ingrid Price (Student Co-Director, 2012-13)

Catherine Baylin

Elizabeth Espinosa

Jane Farrington

Gabriel Ledeen

Nicholas Reed

Faculty Director

Erik Jensen

Rule of Law Program Executive Director

Megan Karsh

Program Advisor

Rolando Garcia Miron

\section{AMERICAN UNIVERSITY OF AFGHANISTAN}

\section{Contributing Faculty Editors}

Ghizaal Haress

Hamid Khan

Haroon Mutasem

Chair of the Department of Law

Taylor Strickling, 2012-13

Hadley Rose, 2013-14

Mehdi Hakimi, 2014- 


$$
\text { pe }
$$




\section{TABLE OF CONTENTS}

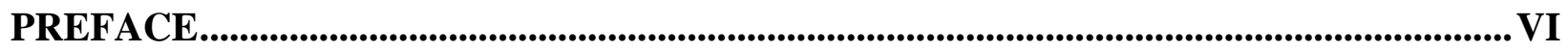

CHAPTER 1: LEGAL HISTORY OF AFGHANISTAN AND THE RULE OF LAW......... 1

I. INTRODUCTION AND OPENING INQUIRIES ........................................................ 1

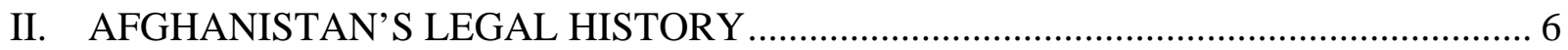

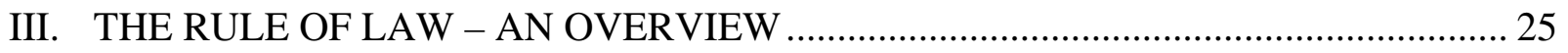

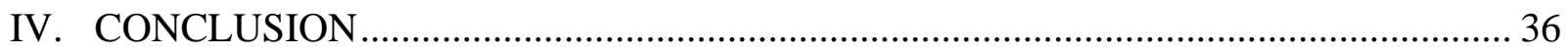

CHAPTER 2: ACTORS AND INSTITUTIONS IN THE CURRENT CONSTITUTIONAL

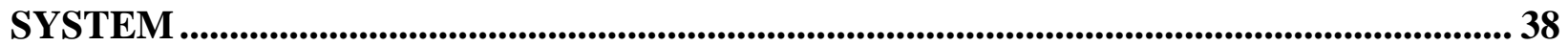

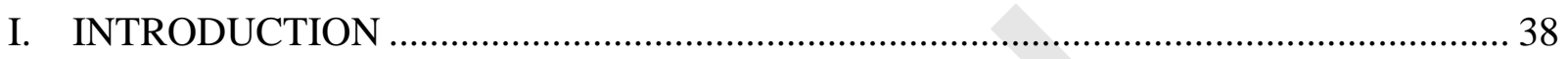

A. Integration of State and Local Judicial Systems ...................................................... 38

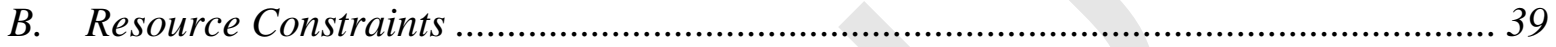

C. Corruption ........................................................................................................ 40

II. THE INSTITUTIONS OF THE LEGAL STRUCTURE OF AFGHANISTAN .............. 41

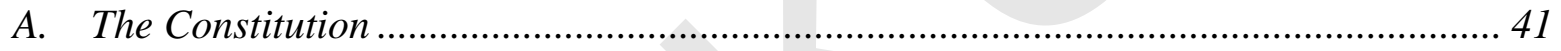

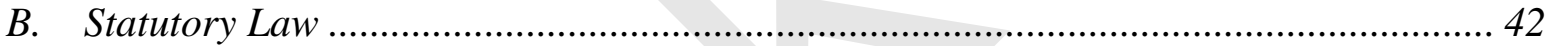

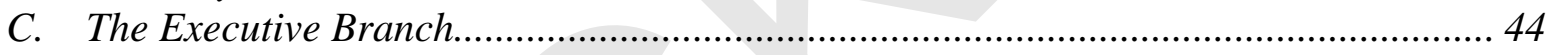

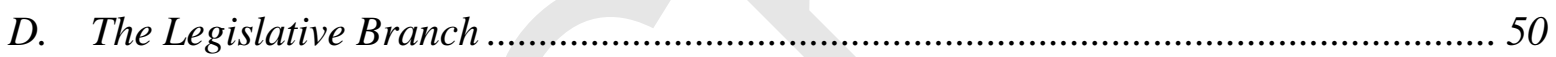

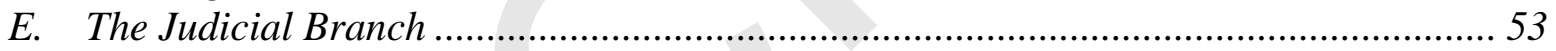

III. THE LEGAL PROFESSION ................................................................................ 57

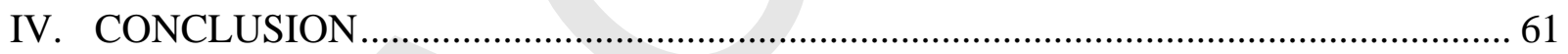

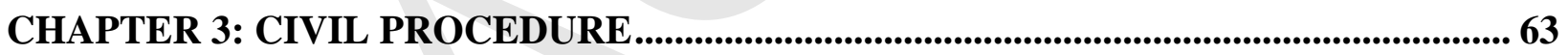

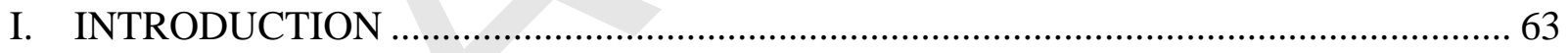

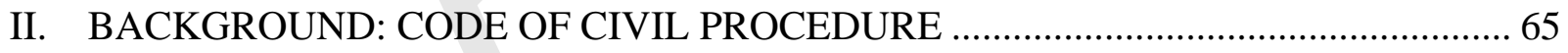

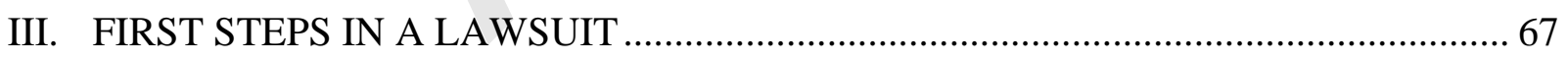

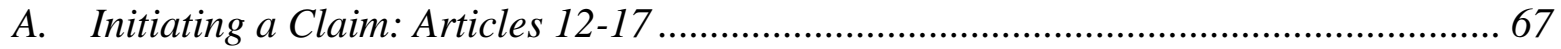

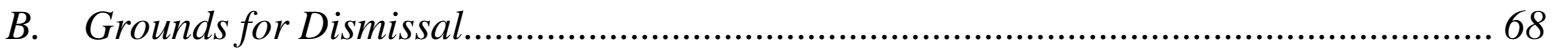

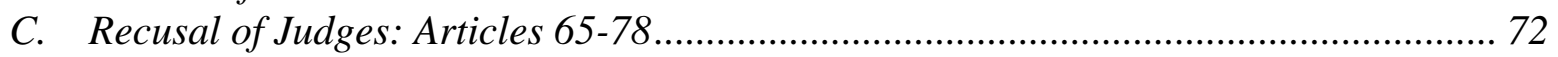

IV. NOTICE, SUMMONS, AND APPEARANCE....................................................... 74

A. Plaintiff Must Appear and Pursue Claim in Court...................................................... 74

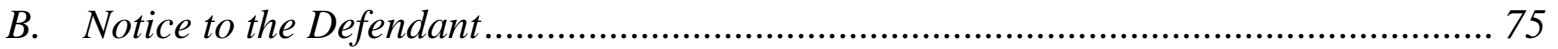

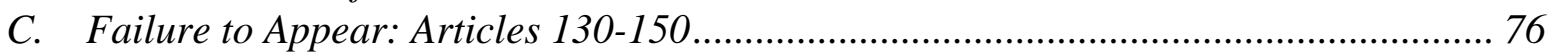

V. CONFLICTS OF LAWS: 1977 CIVIL CODE ARTICLES 23-35_................................. 77

VI. TRIAL PROCEEDINGS: ARTICLES 204-245 …………………………………...... 79

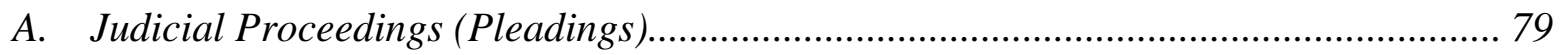

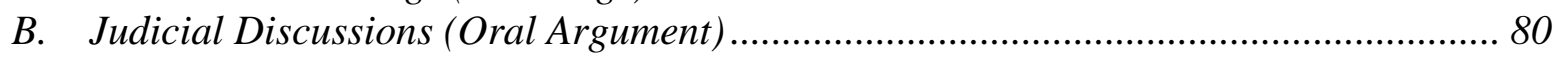




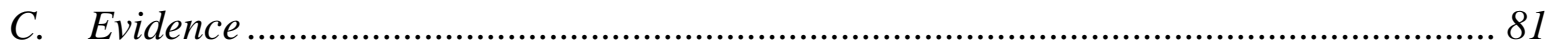

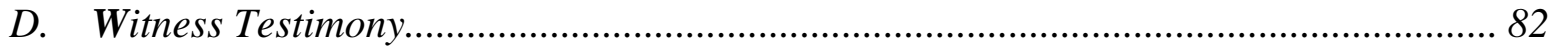

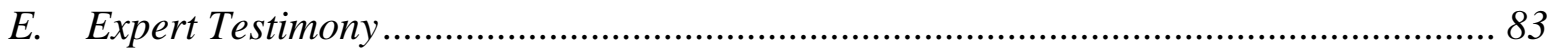

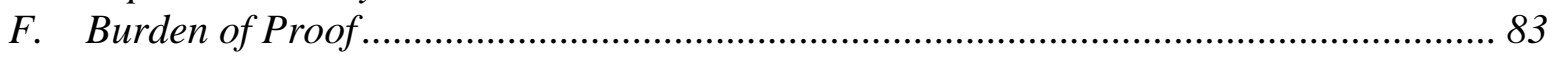

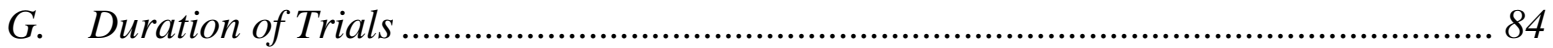

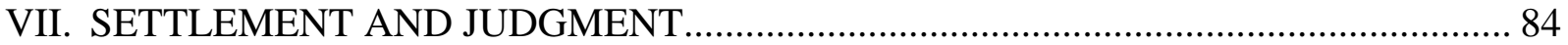

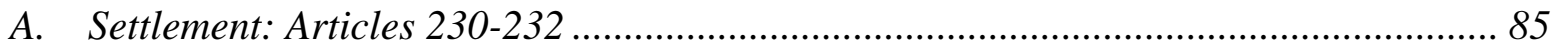

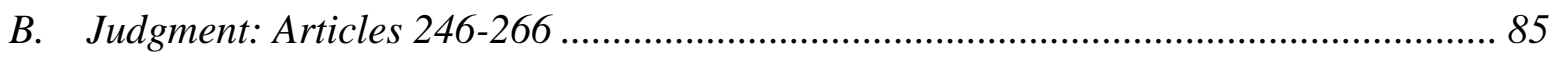

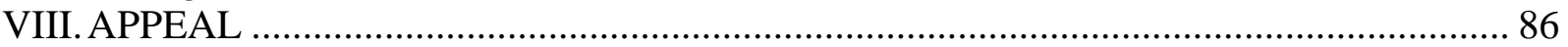

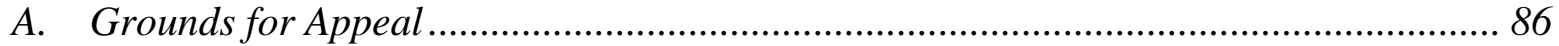

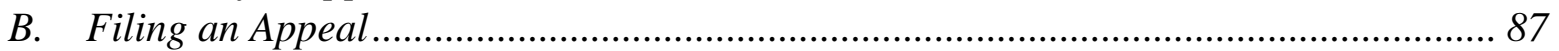

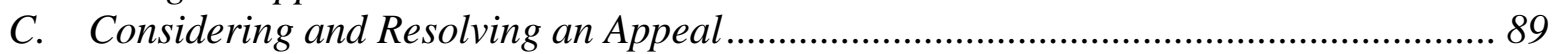

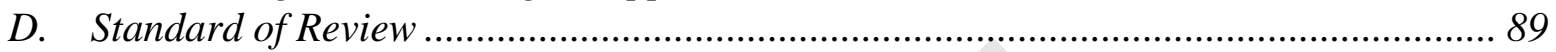

E. Appeal to the Supreme Court .................................................................................. 90

IX. DECORUM AND JUDICIAL ADMINISTRATION: ARTICLES 56-64....................... 90

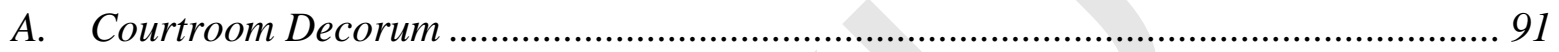

B. Judicial Administration and Judicial Qualifications ................................................. 91

X. CIVIL PROCEDURE IN PRACTICE .................................................................... 92

A. Property Claims: Administrative and Judicial Procedures ...................................... 92

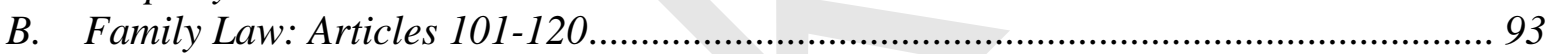

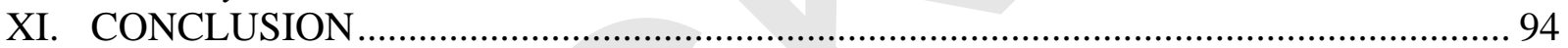

CHAPTER 4: PROPERTY LAW …............................................................................................. 97

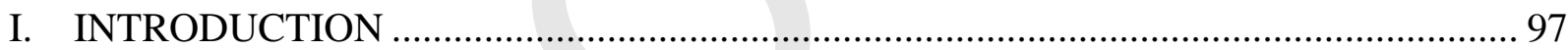

II. PROPERTY OWNERSHIP AND ECONOMIC DEVELOPMENT ………..................... 99

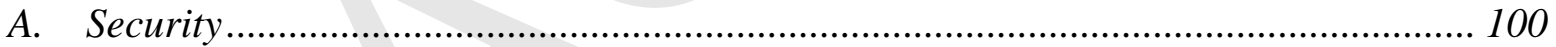

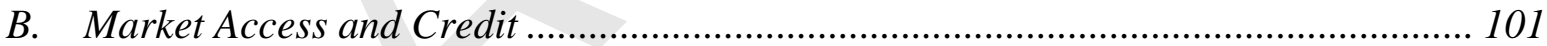

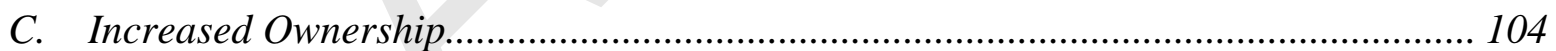

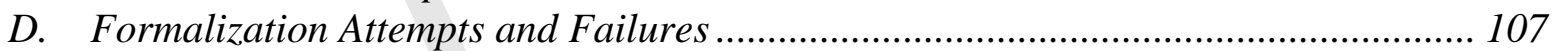

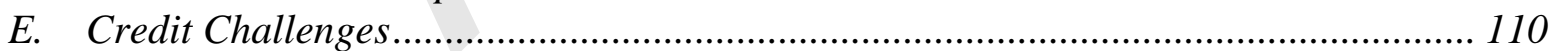

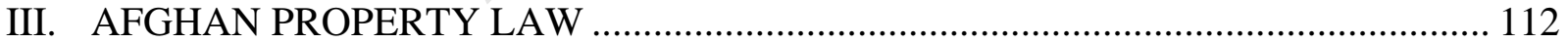

A. The Scope of Property Rights under the Constitution of Afghanistan......................... 112

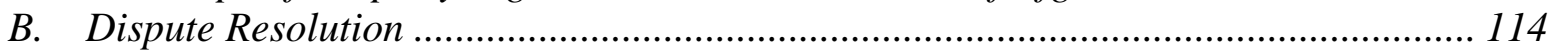

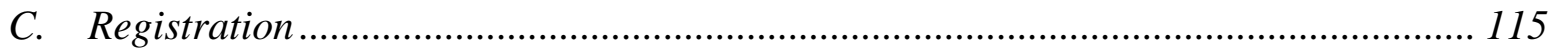

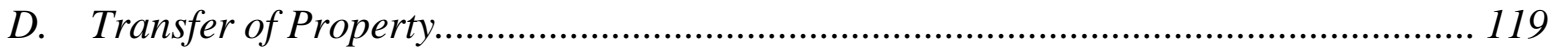

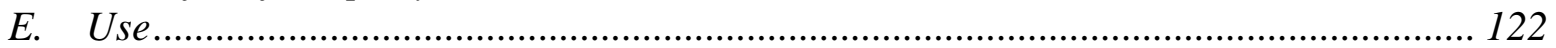

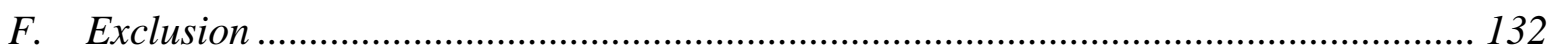

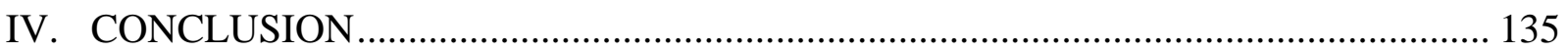

CHAPTER 5: COMMERCIAL LAW ................................................................................... 137

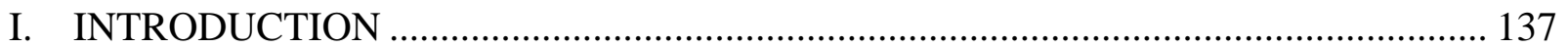

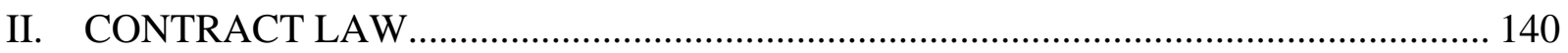


A. Central Concepts of Contract Law...................................................................... 141

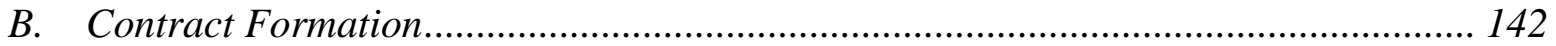

C. Incomplete Contracts and Default Rules …………............................................. 143

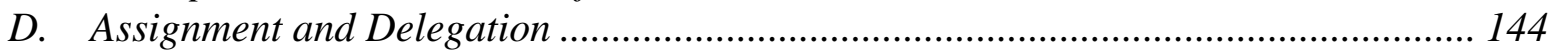

E. Remedies for Breach of Contract ........................................................................... 144

F. Realities of Contract Law in Afghanistan Today ................................................... 145

G. Sources of Contract Law in Afghanistan .............................................................. 147

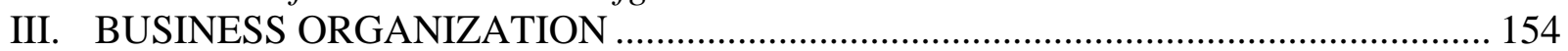

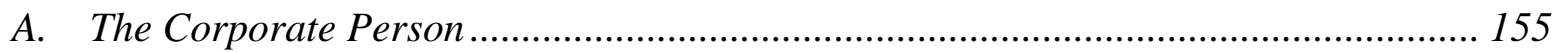

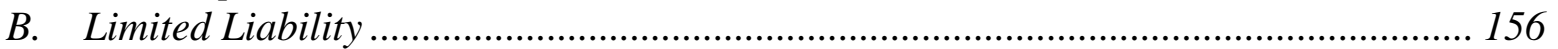

C. The Law on Private Investment in Afghanistan .................................................... 157

D. Issues Related to the Operation of Business Entities in Afghanistan ....................... 158

E. Role of the Afghan Investment Support Agency .................................................... 159

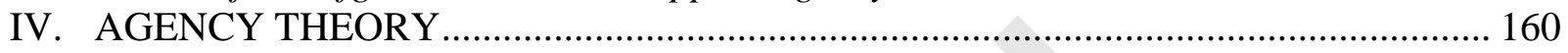

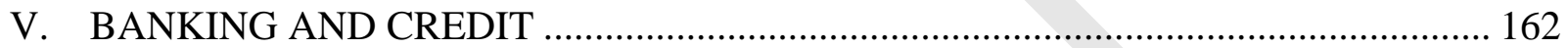

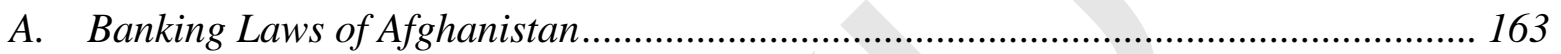

B. Other Laws Governing Loans, Interest, and Bankruptcy....................................... 165

VI. COMMERCIAL LAW ENFORCEMENT AND THE COMMERCIAL COURTS OF

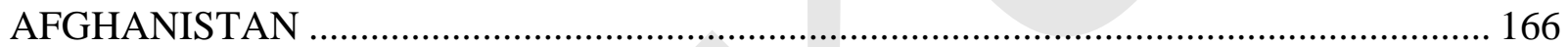

A. Issues Related to Transformation of the Commercial Courts ...................................... 167 VII. TAXATION AND CUSTOMS REGULATION...................................................... 168

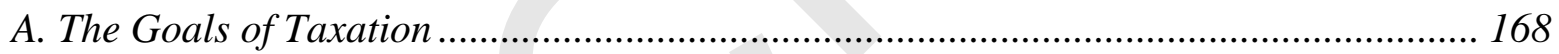

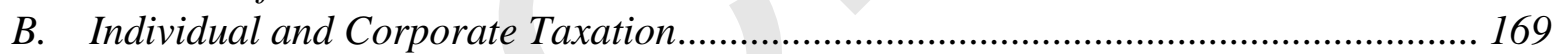

C. Domestic Tax Administration and Collection ……................................................ 170

D. Customs Laws and Regulations …………………............................................ 170

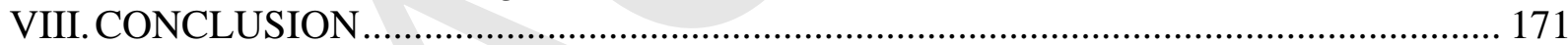

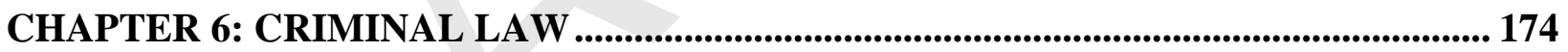

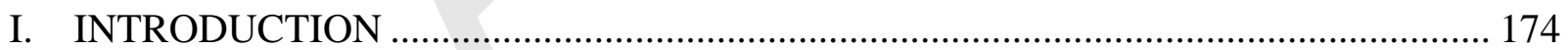

II. HISTORY OF CRIMINAL LAW IN AFGHANISTAN ............................................. 175

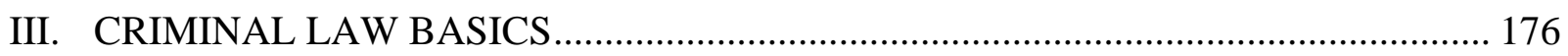

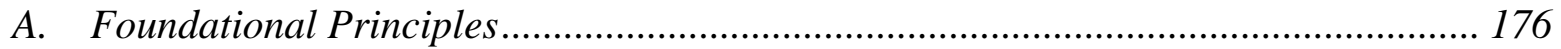

B. Principles of Liability ................................................................................. 178

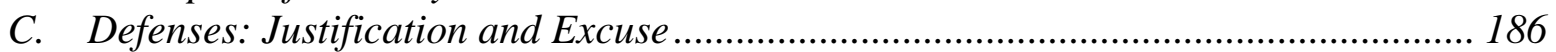

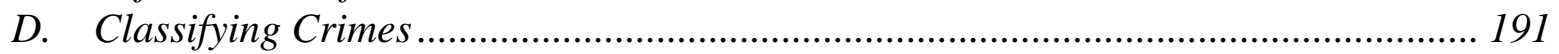

IV. PUNISHMENT AND RESTORATIVE JUSTICE ....................................................... 193

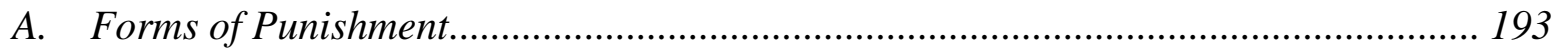

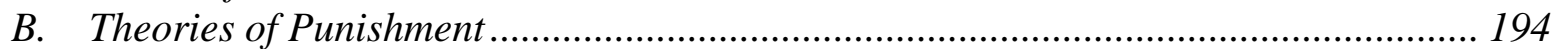

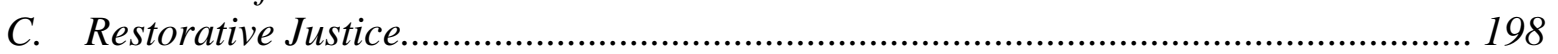

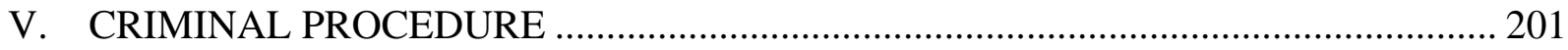

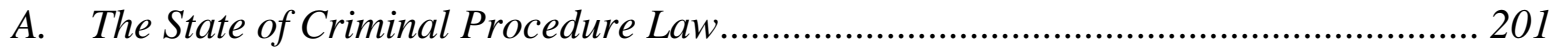




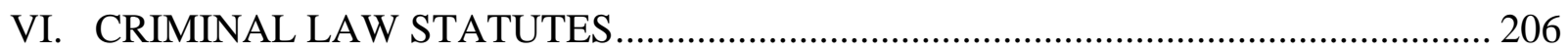

VII. CHALLENGES FACING THE CRIMINAL JUSTICE SYSTEM .............................. 209

A. Integration of State and Local Judicial Systems ..................................................... 209

B. Resource Constraints ..................................................................................... 210

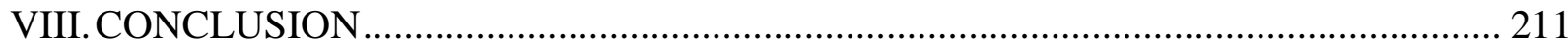

CHAPTER 7: LEGAL RIGHTS IN AFGHANISTAN ....................................................... 214

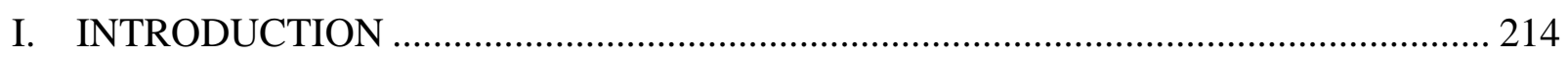

II. THE TRADITION OF RIGHTS IN AFGHANISTAN .............................................. 215

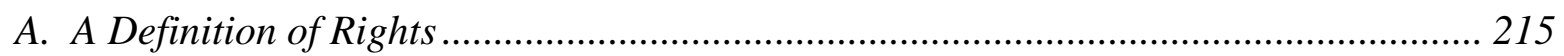

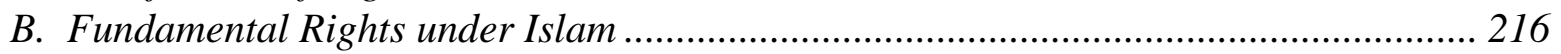

C. History of Constitutional Rights in Afghanistan ........................................................ 218

III. ANALYZING LEGAL RIGHTS IN AFGHANISTAN ............................................. 219

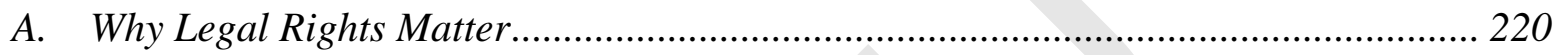

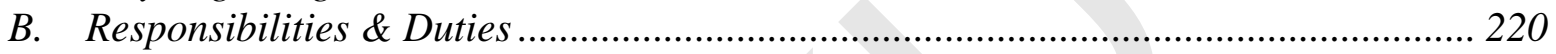

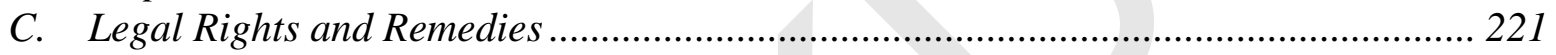

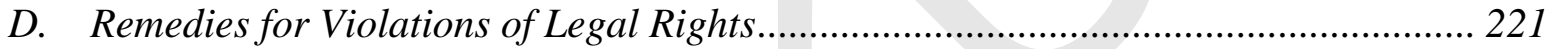

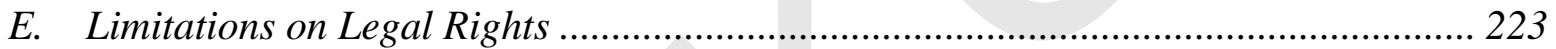

F. Categories of Legal Rights: A Hierarchy of Rights?.................................................. 223

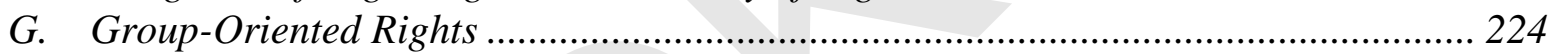

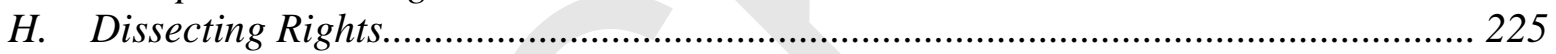

IV. RIGHTS UNDER THE 2004 CONSTITUTION …………....................................... 226

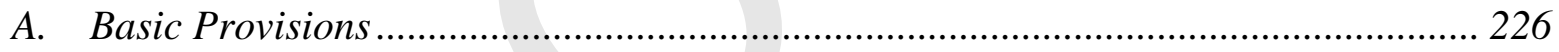

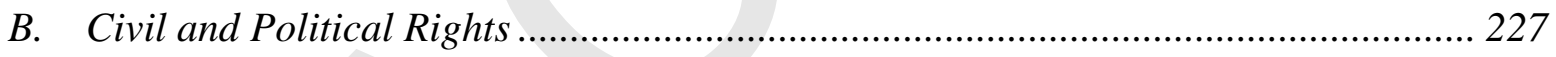

C. Economic, Social, and Cultural Rights ……………............................................. 240

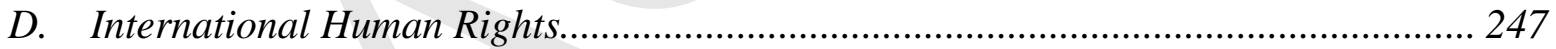

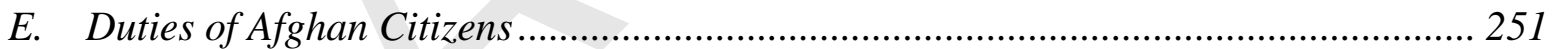

V. RIGHTS ENFORCEMENT IN AFGHANISTAN …………..................................... 252

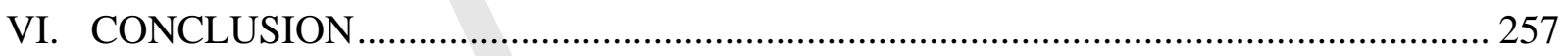

CHAPTER ANNEX: GROUPS EXERCISES \& HOMEWORK ASSIGNMENTS........... 258

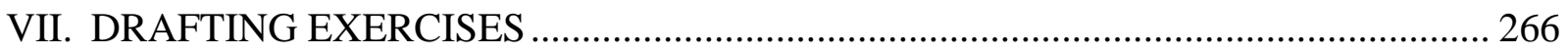

GLOSSARY OF SELECTED TERMS .................................................................................... 269 


\section{PREFACE}

To state the obvious, Afghanistan is currently undergoing a critical transition period. The Afghan people now face the immense task of rebuilding a society and a country. This challenge, while daunting, is also an opportunity for the youth of Afghanistan to effect momentous and positive change as the future leaders of their country. To seize this opportunity, however, Afghanistan's human resources must be revitalized and replenished urgently. The decades-long conflict in Afghanistan has devastated the country's infrastructure and severely stunted the institutions that are central to educating and cultivating leaders. Consequently, the country faces a dire shortage of qualified lawyers. This shortage is felt ever more keenly during this time of transition, as the participation of skilled legal practitioners is crucial to rebuilding the Afghan republic.

In response to this need, Stanford Law School's Afghanistan Legal Education Project (ALEP) began in the fall of 2007 as a student-initiated program dedicated to helping Afghan universities train the next generation of Afghan lawyers. ALEP's mandate and goals are to research, write, and publish high-quality, original legal textbooks, and to build out an equally high-quality law curriculum at the American University of Afghanistan. ALEP's broader vision is to help train the next generation of leaders who will drive Afghanistan's reconstruction and recovery.

On August 20, 2008, the American University of Afghanistan (AUAF) in Kabul inaugurated the first-ever class of its new legal curriculum: Introduction to the Law of Afghanistan (Legal Studies 200). Designed by the ALEP team, this foundational course offers students a comprehensive overview of the current laws of Afghanistan and the legal system established by the 2004 Constitution. Taught by a well-qualified Afghan law professor, Mohammed Haroon Mutasem, the course relies upon two primary texts: the introductory textbook and a supplement containing various Afghan legal documents.

Professor Mutasem and the more than fifty students who enrolled in the course in 200809 provided constructive feedback that led to the creation of the second edition, including a new chapter on civil procedure.

The ALEP team would like to extend acknowledge those individuals and institutions who have made this project possible. ALEP's faculty advisors are Erik Jensen (Co-Director of Stanford Law School's Rule of Law Program) and Stanford Law School Dean Larry Kramer. ALEP has obtained generous support from public and private sources, including a three-year grant from INL at the U.S. Department of State. The ALEP team would also like to acknowledge the support of Deborah Zumwalt, General Counsel of Stanford University and member of American University of Afghanistan's (AUAF) Board of Trustees. ALEP is also delighted to continue its partnership with AUAF and is particularly grateful for the support of AUAF's President, Dr. Michael Smith and Dr. Bahar Jalali, Department Chair of Political Science, Humanities and Law. 
To the students who study this book and other ALEP textbooks, we hope that you enjoy studying, debating, and engaging with these materials, your fellow students, and your faculty. We also hope that you will be able to apply the knowledge obtained and the skills developed in learning to think like a lawyer in whatever career that you pursue - be it in government, in the private sector, or in civil society.

\section{Erik Jensen}

Stanford Law School

Palo Alto, California

June 2011 


\section{CHAPTER 1: LEGAL HISTORY OF AFGHANISTAN AND THE RULE OF LAW}

\section{INTRODUCTION AND OPENING INQUIRIES}

Imagine that you are a legislator in the Wolesi Jirga, the lower house of Afghanistan's National Assembly. One of your peers in the legislature proposes a law, which would require all judges to hold a degree from one of Afghanistan's law schools and not from any other educational institution in Afghanistan or abroad. She asks you to support her law by voting yes in the Wolesi Jirga because she says that it is important for all judges to have the same kind of education. You want to do your own research about whether it would be constitutional to mandate one kind of formal education. Where should you look to determine whether you should vote for the law? Certainly you would look to the 2004 Constitution to determine whether there is anything in the law of Afghanistan that would make this law unconstitutional. You would also look to the Law of the Courts. What other sources of information could you look to?

Legal history is another good source of information that you could consult. By studying legal history, along with the current constitution and laws, you could develop an informed opinion not only about what is legal but also about what has worked in the past and what has proved challenging. You might also discover instances in Afghanistan's past where the education of judges was standardized by law.

Section II of this chapter discusses Afghanistan's rich and varied legal history. Although Afghanistan's legal history stretches back across millennia, this chapter focuses on the period beginning with the government of Amir Abd al-Rahman Kahn, from 1880 to the present. The consolidation of the state and the centralization of the legal system during the reign of Abd alRahman were an important foundation for the legal system that is in place today. This chapter focuses on five distinct legal periods: (1) the centralization of the state from 1880-1923; (2) the constitutional period from 1923-1979; (3) the Soviet occupation from 1979 to 1988; (4) the civil war period, including Taliban rule, from 1979-2001; and, and (5) from 2001 to the present. The different legal institutions of each period are discussed in depth in Section II of this chapter.

Section III of this chapter looks more broadly at the definition, benefits, and challenges of the "rule of law." It attempts to answer the questions of what is meant by the rule of law and why is it beneficial. It also explores challenges to the rule of law and discuses the recent history of Indonesia, the most populous Islamic nation in the world, as a case study of the establishment of the rule of law.

Before beginning this study of the legal history of Afghanistan, however, it is important to examine two foundational concepts. First, what is "justice" in Afghanistan? Second, how do the formal system of justice and the informal system of dispute resolution interact in Afghanistan? The remainder of Section I addresses these questions. 


\section{Justice in Afghanistan}

Conceptions of justice are at the heart of any legal system. People will only follow a law if they believe it is just. Certainly citizens of a state sometimes follow the law out of fear, but in a constitutional system with different branches of government, the law is supposed to represent the people's vision of what justice is.

Definitions of justice often depends on culture, religion, and governmental structures. What is justice for one nation, province, or even town may not be justice in another location. Therefore, it is important to be sensitive to the cultural context in which you are thinking about justice. Justice can often depend on the religion and values of the community concerned. As discussed below, religion has played a significant role throughout Afghanistan's history in defining justice.

Since the beginning of the state of Afghanistan and especially since the consolidation of the state under Amir Abd al-Rahman Khan, religious beliefs have played a major role in the definition of justice in Afghanistan. Abd al-Rahman created a legal system with regularized courts and procedures with the underlying understanding that the function of government was to implement God's law on earth. The ultimate aim of the legal system was to achieve a state where the laws of God were followed and obeyed. In other words, the law of the nation was the law of the Shari'a. Although other sources of law have developed throughout history in Afghanistan, the religiously inspired conception of justice has always played an important role. Article 3 of the 2004 Constitution requires that no law may contravene the principles of the Shari'a, demonstrating that the idea of religious principles as justice is still foremost in Afghanistan today.

Culturally, justice in Afghanistan often has a communal component. This means the justice is often not merely personal, meaning that the outcome does not just affect one person. Instead, justice is often seen as benefiting a whole group of people in a community.

There is also a broader sense of justice in Afghanistan as part of the democratic system. Justice in a democracy is supposed to represent the will of the people, the voters, who are charged with selecting their government. Therefore, in a democracy, if the citizens of a state do not believe the law is just, then it cannot be legitimate. By exercising their right to free speech, advocating for causes, and voting in elections, citizens in a democratic society can express their beliefs about what justice is.

Is justice simply the end result achieved or is justice a fair method or process used to achieve that result, regardless of what the result is? For example, has justice been achieved when a man who murders another person and is sent to jail for life after an unfair trial? Or is justice achieved when a man who murdered another person is freed because there is not enough evidence to prove his guilt or because the evidence was gathered improperly? These two conceptions of justice are referred to as procedural justice (fair methods) and substantive justice (fair result). They can, and often do, exist simultaneously in nations that govern through the rule of law. 
In Afghanistan, as everywhere, there is no definitive answer to the question of what justice is. There is only the ability to look to the past - to what the laws were and how they reflected the values of the people.

\section{Discussion Question}

How would you define justice? What are the elements of justice? Which result in the murder case above do you think is more just?

\section{Legal Pluralism in Afghanistan}

Legal pluralism refers to situations in which there is more than one source of law, each of which exerts control over the behavior of individuals in that society. Afghanistan is a nation with legal pluralism because in addition to the formal written law - the civil and criminal codes - other non-written, informal, or tribal law has significant effects.

Section II of this chapter will introduce you to the formal legal institutions that have governed Afghanistan since 1880. It is important to keep in mind, however, the essential role that informal, community-based legal institutions have played throughout this time period as well. This textbook does not look in-depth into the informal legal processes, but because they are the most widely-used system of settling disputes, both historically and today, it is important to discuss them briefly.

Informal legal institutions, also called alternative dispute resolution, are the processes outside of the formal court system through which individuals settle legal disputes. Imagine that there is a dispute over land you claim is yours, which someone else is using and living on. Where can you turn for help in settling this dispute? You can go to the Primary Court for your district and lodge a legal complaint with the judges there. What if you don't want to wait for the legal process, which can be slow, and instead want to work out the dispute right away? You could go to a respected group of elders in your town and ask them to help mediate the dispute and recommend a resolution. This second type of dispute resolution is called alternative dispute resolution because it is a process outside of the state's institutions. Conversely, formal dispute resolution is when disputes are settled in the state-controlled system. Afghanistan has a rich history of legal pluralism where informal systems existed before the formal state institutions and now complement them.

Any discussion of Afghanistan's legal system would be incomplete without addressing the central role played by these informal institutions, such as shuras and jirgas. These institutions are based upon local custom, tradition, and religious practices and have existed in Afghanistan for centuries. Such terms, however, can be misleading. Shuras are local councils, either religious or secular, that are typically convened on an as-needed basis to resolve disputes or decide issues of community governance or resource management. The two principal types are: shuras of the Ulema (Islamic scholars) or shuras of elders. Jirgas are similar to shuras and more prevalent among Pashtun tribes. A jirga refers to a gathering of elders or leaders who sit in a large circle to resolve a dispute or make collective decisions about an issue of community-wide 
importance. These informal institutions do not enforce the civil or criminal laws of Afghanistan, but rather Islamic Shari'a law, customary tribal law, or the collective wisdom of elders.

Too often, "informal" is interpreted as "unsophisticated." While it may be true that local adjudicatory systems rely on oral tradition rather than written rules, the local processes are, in fact, highly sophisticated. This sophistication is visible in both the decision-making processes of local systems, as well as the structures of those systems. In a typical jirga, for example, decisions are made in accordance with well-developed understandings of morality and justice (such as Pashtunwali). In some cases, there is even an established system for appealing jirga decisions to a higher group of elders. Thus, Afghanistan's local adjudicatory systems share many of the "formalities" of codified legal systems, and can rightly be viewed as institutions applying customary law. And while legal scholars may disagree as to the outcomes reached by the local adjudicatory systems - one major criticism is the manner in which women are treated by customary law-the dismissal of the local systems as primitive and crude is both inaccurate and unhelpful; it is this type of law that still governs the daily lives of most Afghans today, especially in areas outside the major cities.

These practices still flourish today, and are important sources for the settling of disputes. In areas where the Primary Court has very many cases and not enough judges, alternative processes can help speed along the resolution of disputes. Further, in some towns the Primary Court is not yet operating, so alternative processes are the only way that individuals can settle disputes at all. Many citizens of Afghanistan, especially in rural areas, turn to shuras or jirgas to resolve disputes because they are considered more fair, efficient, accessible, and respectful of local values than the state system. Corruption, lack of accessibility, and slow response are three common complaints about the formal justice system. Finally, these alternative processes, which are community based, can help solve disputes in a cooperative manner and allow the parties to live peacefully together in the future. These are some of the many benefits of the informal system in Afghanistan.

This textbook, however, does not focus on these informal legal institutions. You may be asking yourself if the informal system works so well, why does this textbook focus on the formal, state-based legal system? The goal of this textbook is to inform you, citizens and future leaders of Afghanistan, of the current formal legal institutions in Afghanistan and how they work. This will be important when you start a business or practice as a lawyer because you will operate within the formal legal system every day. It is important to know how to use the formal legal system because it is the basis on which the state of Afghanistan is founded. There are unique benefits to this formal system, which will be discussed in Section III of this chapter. Further, there are some drawbacks to the informal system. Informal institutions lack the procedural safeguards, uniformity, and oversight present in formal courts, and they sometimes suffer from a lack of transparency. Additionally, codification of law allows it to be formally evaluated and amended if the people believe that it is not serving the interests of society.

Still, as an ethical lawyer or businessman, it is important to be mindful of these alternative systems for two reasons. First, as will be discussed in Section II of Chapter II, a lawyer must always keep in mind every method of settling a dispute for his or her client. Sometimes, it may be that the best way to settle a dispute is through one of these informal 
methods because it is less costly or will be better accepted by the other party to the dispute. Second, it is important to know about these other dispute resolution systems simply because of their prevalence. This text encourages you to think about these alternative dispute resolution systems as you know them and to weigh their effectiveness and desirability against that of the formal institutions you study.

\section{An Example of the Formal and Informal Systems}

Imagine a situation in which three people move from the provinces to Kabul. One is from Lashkar Gah, one from Torghundi, and one from Mazar-i-Sharif. While in Kabul, two of these people attack the third and steal money from his pocket. The robbers are identified and detained. Assuming that local adjudicatory systems in Lashkar Gah, Torghundi, and Mazar-i-Sharif punish assault differently, and there is not yet an accepted standard of punishment in Kabul, how should the criminals be punished?

In a system of local adjudicatory bodies applying customary law, this is a difficult question to answer. The authority of a local system rarely extends beyond its territory, so it is difficult to determine which law applies. In a system of universally applicable codified law, however, it is easy; there is no question as to which law applies.

Further, under a system of codification people can rely on the published criminal code. This can be important in cases when a person is unsure if a particular act is considered criminal. With a published penal code, such a person can find an answer without having to convene a jirga or consult an expert. In other words, the law becomes both easily accessible and standardized, which are important advantages for those making business, family, or personal decisions that may involve criminal law questions.

Finally, codification of laws-including criminal law-can be an important aid in attracting foreign investment and simplifying international relations. Potential investors and foreign governments can rely on published laws when making decisions, avoiding the expense of consulting experts in the local systems.

\section{Discussion Question}

1. Why are informal institutions so prevalent in Afghanistan? Does their existence strengthen or weaken Afghanistan's legal system?

2. If your rights were violated, would you seek a remedy from informal institutions? What are the advantages of using local custom instead of codified law as the basis for resolving disputes? What are the drawbacks?

3. What is the best way to ensure uniformity of results within informal institutions? Should government authorities supervise informal institutions? 


\section{AFGHANISTAN'S LEGAL HISTORY}

With the two principles of justice and legal pluralism in mind, this section discusses the legal history of Afghanistan since 1880. Learning legal history is important because the law of today is not just written on a blank slate. The 2004 Constitution draws inspiration from several constitutions that came before it, and many of the laws that are in force today date from previous governments. The history of past legal institutions and their successes and failures inform the government of today when it is deciding which laws to pass and how it wants to govern. Fortunately for students of the law of Afghanistan, Afghanistan has a rich and varied legal tradition; it has been governed by six different constitutions and by governments as different as a constitutional monarchy and a communist politburo.

\section{Reading Focus}

As you read Afghanistan's legal history, think about what effect this legal history may have on the government of Afghanistan today. Is there a period or event that you think is particularly influential in present day Afghanistan?

\section{The Consolidation of the State under Amir Abd al-Rahman Khan 1880-1921}

Our study of legal history begins with Abd al-Rahman Khan's rise to the throne in 1880 . Although Abd al-Rahman's government was influenced by those who came before him, we begin our study in the 1880s because it is the era of the emergence of many of the elements of the current judicial system. Many of the reforms undertaken in that period continue to shape the judiciary today. Abd al-Rahman believed that during his reign he laid "the foundation stone of a constitutional government ... [even] though the machinery of a representative government had not taken any practical shape yet."

Soon after Abd al-Rahman became king, he began a program to consolidate his control over the state. He centralized and systematized the court and legal system. Three of his innovations are fundamentally important to the legal history of Afghanistan and continue to influence the legal system today: the creation of a court system, the provision of a judge's manual, and the installation of the boxes of justice.

A comprehensive court system was set up in each district to enforce the two types of law of the government: Shari'a law and royal edict. The court system was divided into two branches: the religious courts and the state courts. The religious courts handled issues of family law, criminal law, and personal law. The state courts were in charge of cases that related to commerce, taxation and government employees. This separation between two branches of the courts continued until the 1964 Constitution. Overall, however, the structure of the court system is very similar to its structure today. There were three types of courts in Afghanistan during this period: religious courts, criminal courts, and commercial courts. The commercial court was an important innovation. The court was composed of both Muslim and Hindu judges, a mixture that 
was unique to that court. The extensive amount of trade between India and Afghanistan at the time meant that merchants of both creeds appeared before the court. Among the courts sponsored by the state, there was a hierarchy of review within them.

The district courts (qazis) adjudicated disputes at their inception. Their decisions were made in accordance with the Shari'a on criminal cases. The judges of these courts were advised and assisted by a mufti who acted as legal and religious advisor. These were assisted by a large number of bureaucrats who managed the cases and made sure that all was recorded correctly.

The district courts reported to the hakim, the higher court of criminal appeal, thorough a monthly report that was reviewed for its conformance with the Shari'a. The hakim then reported to the khan-i 'ulum, the main court in Kabul which oversaw the courts outside of the capital. This highest court of appeal was a unique innovation of the Abd al-Rahman government that has remained in place, in the form of the Supreme Court, until today. In fact, the entire structure of the courts during this time mirrors the structure of specialized district court, appellate court, and Supreme Court that exists today.

Abd al-Rahman was the final authority over any case brought before any court. Individuals could personally appeal to him after the conclusion of their case if they disagreed with the result. Abd al-Rahman held a weekly audience during which petitioners could inform him of their case and argue for his resolution of it. The king even set up special days for female petitioners and all historical accounts of the period indicate that they were popular. As part of his codification and regularization of the courts, Abd al-Rahman institutionalized the Hanafi school of Islamic jurisprudence as the law of Afghanistan. This codification of the Shari'a was fundamentally important to Abd al-Rahman's government because, as he wrote, the state "exists to bear witness to God amid the darkness of this world, and the function of the government is to act as the executive of the law." In fact, a year before Abd al-Rahman's death, a legal commentator published a book on the law of Afghanistan and said that:

The law of Afghanistan in the present day [1900] may be easily placed under three headings: (1) those of Islam; (2) those of the Amir, which are based on Islamic laws, the opinions of the people, and the Amir's own personal views and ideas; and (3) customary laws of the various tribes. In all criminal and political cases, practically the chief part of the law has been made by the Amir, and so in cases as to the Government revenue. But the rest, Islamic law is the general rule. Thus very little is left to custom.

Another fundamental change in the legal system was the creation of a judge's manual and the standardization of legal procedure. The Fundamentals for Judges (asas al-quzat) was a 140page instruction manual containing 136 rules for court procedure and the deciding of cases. It was the first manual of its kind in Afghanistan. The manual had three parts. First, the judge was instructed on ethics and rules of conduct with relation to the parties to the case. Second, the judge was given direction on how legal documents were to be prepared. Finally, the office of the judicial inspector (muhtasib) was created and regulated. The first part of this judicial manual is the most important for the study of the law of Afghanistan. The system of procedure was the first attempt by the government of Afghanistan to extend a regularized judicial system over the whole 
of the country and to codify the Shari'a as the law of the state. The rules in the Fundamentals for Judges were comprehensive, addressing which law applied in which circumstance and even how far apart the parties were required to sit in the court (two meters).

The final important innovation that was put in place after 1880 was the use of the Boxes of Justice (sanduq-i 'adalat), one of which was placed in each district. It was literally a large, locked mailbox in which petitioners could place sealed letters. It allowed individuals to directly petition the king for aid in resolving disputes by writing him a letter. The boxes were taken to Kabul twice a year and opened for the king to read the petitions. He would then send a reply through the mails to the petitioner. This practice reinforced the king's role as the ultimate decision maker in the judicial system.

However, beyond involving the king in legal disputes, this practice was important for two other reasons. First, the Boxes of Justice brought the formal legal system, the dispute resolution apparatus of the state, into the life of each citizen of Afghanistan. This allowed individuals, often for the first time, to settle a dispute through the state-based system. It also allowed those who could not reach a district court or Kabul to petition the king directly and have access to the formal legal system. Second, these boxes allowed individuals who would not usually initiate legal disputes, such as women or the elderly, to use the boxes and defend their legal rights.

\section{The Constitutional Period}

\section{What is a Constitution?}

A constitution codifies basic rules and principles of government into a written document. A constitution determines the procedures for governing and the powers of the different branches of government. Overall, the constitution is the foundation of the political and legal system on which all governing actions of the country rely.

The next major watershed moment in the legal history of Afghanistan occurred during the reign of Aman Allah Khan, who rose to power in 1919 after the assassination of his father, Habib Allah Khan, the designate of Abd al-Rahman. Similar to his predecessor, Abd al-Rahman, Aman Allah embarked on an ambitious process of centralization and legalization that included writing Afghanistan's first constitution, which was approved by the Loya Jirga in Jalalabad in 1923. The 1923 Constitution was influenced by many sources, including the Turkish constitution under Kemal Ataturk and the French constitution. A prominent Turkish legal scholar, Badri Bey, was a chief advisor to the constitutional project in Afghanistan.

The first draft of the constitution included a broad vision of the formalization and centralization of government. The 1923 constitution significantly limited the power traditionally held by religious and tribal elders by concentrating authority in the king. This constitution did not provide for a legislative body and instead vested all of the lawmaking power in the hands of the king. It also prohibited all courts outside of the formal state courts, greatly reducing the power of the religious courts. Article 55 of the 1923 constitution stated that no court other than 
the regularly constituted tribunals sponsored by the state could hear a case. At present, there is currently no constitutional provision or law prohibiting the use of the informal justice system.

To institute the requirement of using the formal justice system, the king created four types of courts: the Court of Reconciliation (mahkama-e-islaheya), the Court of First Instance (mahkama-e-ibtedaya), and Provincial Court (mahkama-e-murefia), and the Court of Cassation (mahkama-e-tamiz). Any dispute was first referred to the Court of Reconciliation to see if a settlement could be worked out between the two parties. If no settlement was possible, the matter was then sent to the Courts of First Instance. A judgment of the Court of First Instance could be appealed to the Provincial Court, and its decision could again be appealed to the Court of Cassation.

The two other most important developments in the constitution concerned individual rights and the sovereignty of the state. The constitution granted the same basic rights to all citizens without regard to religion or gender. This was an unprecedented recognition of equality. Article 1 strongly affirmed Afghanistan's independence. Aman Allah strongly believed that Afghanistan could not be sovereign and write a constitution unless it was absolutely independent from external forces, namely the British, who had exercised control over Afghanistan until the conclusion of the War for Independence in 1919. Important provisions of the Constitution of 1923 are excerpted below.

\section{Constitution of 1923 - Selected Provisions}

\section{Article 1}

Afghanistan is completely free and independent in the administration of its domestic and foreign affairs. All parts and areas of the country are under the authority of His Majesty the King and are to be treated as a single unit without discrimination between different parts of the country.

\section{Article 2}

The religion of Afghanistan is the sacred religion of Islam. Followers of other religions such as Jews and Hindus residing in Afghanistan are entitled to the full protection of the state provided they do not disturb the public peace.

\section{Article 8}

All persons residing in the Kingdom of Afghanistan, without respect to religious or sectarian differences, are considered to be subjects of Afghanistan. Afghan citizenship may be obtained or lost in accordance with the provisions of the appropriate law.

\section{Article 11}

The press and the publication of domestic newspapers are free in accordance with the appropriate press law. The right to publish newspapers is reserved to the Government and to citizens of Afghanistan. Foreign publication may be regulated or restricted by the Government. 


\section{Article 16}

All subjects of Afghanistan have equal rights and duties to the country in accordance with Shari' $a$ and the laws of the state.

\section{Article 25}

The responsibility for the administration of the Government is vested in the Council of Ministers and independent departments. The chairman of the Council of Ministers is His Majesty the King.

\section{Article 28}

His Majesty the King will select and appoint the prime minister and other ministers.

\section{Article 29}

The Council of Ministers will formulate the foreign and domestic policies of the Government. Decisions of the Council of Ministers, treaties, agreements and other matters that may require ratification by His Majesty the King will become effective only after such ratification.

\section{Article 39}

There is hereby established a State Council in the capital of the Kingdom and local councils in the provinces and district centers, these councils to act as advisory bodies.

The concentration of power in the central government proved too much for the local and religious leadership at the time. It limited their power to govern and resolve disputes, leading local leaders to rebel against the king. In 1925 the constitution was amended during the Loya Jirga to compromise with these leaders. This was the first instance when the Loya Jirga was called upon to approve the constitution of Afghanistan, a practice that has continued with each subsequent constitution. Specifically, the 1925 amendments focused on reintegrating religion officially into the constitution. The greatest change was to Article 2, which, after the 1925 amendments read:

The religion of Afghanistan is the sacred religion of Islam and its official religious rite is the sublime Hanafite rite. Followers of other religions such as Jews and Hindus residing in Afghanistan are entitled to the full protection of the state provided they do not disturb the public peace. Hindus and Jews must pay the special tax and wear distinctive clothing.

The 1923 Constitution is overall seen as a vision of centralization and formalization, which then became the undoing of the regime that wrote and enacted it. The cavalier nature with which the constitution addressed the concerns of local and religious leaders ultimately resulted in the regime's demise. Subsequent governments have been more careful to be in touch with local sentiments before proposing major legal reforms.

Despite its limitations, the Constitution of 1923 has constrained later regimes because it established the tradition of constitutional rule. No monarchy after Aman Allah dared rule without a constitution legitimizing its government. 
Aman Allah was succeeded by the brief reign of Habib Allah Kalakani, who instigated a coup against Aman Allah. Soon thereafter, Muhammad Nadir Shah was proclaimed king by a Loya Jirga in September 1930. One of his government's first orders of business was to create a new constitution in 1931. He was determined to avoid the fate of Aman Allah and returned power to the hands of the local leaders. Notably, Nadir Shah still felt constrained to create a constitution because of the precedent set of having a government with limited powers. Therefore, Nadir Shah enacted the Fundamental Laws of the Exalted Government of Afghanistan in 1931.

The 1931 Constitution was based on the French, Iranian, and Turkish constitutions of the period. It was also influenced and shaped by the Hanafi religious leaders that were consulted during its drafting, a nod to Nadir Shah's determination that his constitution would not be out of touch with the sentiment of the people. This constitution declared the religious law of the Hanafi school of Sunni Islam as the official law of Afghanistan and required adherence to Islam and Shari' $a$ in legislative action. In fact, the legislation passed by the parliament as part of the constitutional system was, by law, inferior to the unwritten Shari' $a$ law. Further, in Article 5, the king was required to carry out his duties in accordance with the law of the Shari'a and the dictates of the Hanafi jurisprudence. The courts were also required by Article 88 to decide cases in accordance with the Holy Hanafite creed. Interestingly, the basic organization of the courts was to be controlled by a secular code (Art. 94).

The 1931 Constitution did take a bold step in creating Afghanistan's first legislative body with two houses: the Upper House (majlis-e-ai'yan) and the National Assembly (majlis-e-shura$e$-milli). Members of the Lower House were elected for three years by the people of their district while members of the Upper House were appointed by the king. The legislature had no formally binding lawmaking powers, but it could recommend laws to the king.

\section{Constitution - Selected Provisions}

\section{Article 1}

Islam is the sacred religion of Afghanistan and the religious rites performed by the state shall be according to the provisions of the Hanafi doctrine. The King of Afghanistan should be from Hanafi sect. Other religious followers can live in Afghanistan and their rights will be protected as a citizen unless they disrupt the peace.

\section{Article 3}

Kabul is the capital of Afghanistan and all citizens of Afghanistan have equal rights and there will be no extra privileges for Kabul citizens than those in any other provinces in Afghanistan.

\section{Article 5}

To appreciate the patriotism, devotion and performances of his Majesty and patriot Muhammad Nadir Shah has given Afghanistan on independence and survival and overthrowing the foundation of brutality in Afghanistan, the nation of Afghanistan considers him a meritorious and deserving King and also because his Excellency is committed to act according to the Islamic Shariea and Hanafi sect as well as main principles of the Afghanistan government and will consider the independence of Afghanistan as one of his top priorities and will be honest to the Afghanistan nation, Afghanistan is committed in transferring the Kingdom of Afghanistan to the 
family of this patriot King in accordance to the selection of his Excellency and the nation of Afghanistan.

\section{Article 10}

All Afghanistan citizens are obligated to obey all state principles and laws on religious and political affairs. Liberty is the natural right of the human being. This right has no limitations except the liberty of others and public interests as defined by the law.

\section{Article 27}

The National Consultative Assembly in Afghanistan manifests the will of the people and represents the whole of the nation.

\section{Article 88}

The court of Shariat decides cases according to the Holy Hanafite creed.

\section{Article 94}

Categories and functions of courts are defined in rules pertaining to basic organizations.

Soon after the constitution was enacted, Nadir was assassinated and the Loya Jirga announted Zahir Shah king. Although he was technically only a figurehead from 1933 to 1973, he still exercised considerable power and was assisted by a succession of prime ministers during this time. From 1929 to 1946, the King's uncle, Hashim Khan, acted as prime minister. From 1946 to 1953, another uncle, Shah Mahmud, held the position.

Under Shah Mahmud's rule, the 1949 election of the parliament voted in a majority of reform-minded delegates. This was the first period of true representative governance in Afghanistan. Laws had to be passed by an elected parliament instead of being put into effect directly by the king. One of the most important reforms passed by the National Assembly during the period was a law permitting freedom of the press.

In 1953, Shah Mahmud was ousted by Daoud, who became prime minister. Daoud focused on changes in domestic law through the existing constitutional structure. Perhaps the most significant domestic reform during this period was the opening of public education to women. Daoud also embarked on a major project of codification of the law. The process of codifying Afghanistan's laws was Daoud's lasting legacy. He began the process of developing Afghanistan's civil law system that has continued to the present.

Daoud resigned in 1963 and was replaced by Dr. Muhammad Yousuf. He, along with the king, immediately announced the formation of a seven-member constitutional advisory commission to write a new constitution. Dr. Louis Fauger, a French constitutional expert who wrote the Moroccan Constitution, assisted the commission. In February 1964, the first draft of the constitution was presented to the king who then called a twenty-nine member constitutional committee to evaluate the document. 
In May 1964, the constitutional review committee completed its work and presented the constitution to the 455-member Loya Jirga for its approval. This was not the first time the Loya Jirga had been called upon to approve a constitution, but it was the first time that it did so in the structure of a constitutional rubric. The constitution specifically gave the Loya Jirga this role, and other provisions of the constitution gave the Loya Jirga a specific role in the constitutional monarchy, including the ability to approve the monarch. This was, therefore, the first time the Loya Jirga was "constitutionalized."

The Loya Jirga passed most of the articles of the draft constitution without significant debate. However, the status of the courts attracted significant attention. Three points of view emerged. Traditional religious leaders argued for the administration of justice in accordance with Shari'a law. Other individuals supported a constitutionally independent judiciary. The final group argued for a more expansive conception of individual rights in the constitution to be protected by an independent judiciary. At the end of the discussion, those favoring an independent judiciary won.

At the time it was passed in 1964, the constitution of Afghanistan was unique in the Islamic world because it accepted a separation between religion and the state's governing institutions. Article 1 of the constitution was an innovation because it established a government based on the sovereignty of the people, rather than religion. Islam remained the official religion of the country per Article 2, yet the different role played by religion in the constitution was striking. Other innovative provisions included the formal equality of men and women and all tribes before the law, freedom of thought and expression, the protection of private property, and the right to form political parties.

Probably the most important provision of the constitution, in terms of its difference from the 1931 Constitution, was the mandated supremacy of the statutory law over Shari'a law. In contrast to the 1931 Constitution, the 1964 Constitution made statutory law legally more binding than the Shari'a law once it was passed by the parliament and accepted by the king. Further, courts were required by Article 102 to apply first the provisions of the constitution and the laws of Afghanistan when deciding a case. After the 1964 Constitution was passed, Shari'a law was only used to decide a case in the absence of statutory law on the subject. This structure is mirrored in the way courts decide cases in Afghanistan today.

Further, the Supreme Court, for the first time, was empowered to decide whether the laws passed by the parliament were in accordance with the provisions of the constitution. Courts overall were obligated to decide cases before via provisions of statutory law, whereas in the 1931 Constitution they were required to do so using the Hanafi school of jurisprudence. The constitution also created a unified and regularized judiciary under the control of the state, whereby the state appointed the judges who would fill the positions and adjudicate cases under the aegis of that state. This was the also first time, per Article 97, that the judiciary was named officially as a separate co-equal branch with the executive (the king) and the legislature, laying the foundation for the current separation of powers under the 2004 Constitution. This was a break with the past, as there had existed two parallel functioning judiciaries since the 1880s with religious and state courts exercising different roles. The 1964 Constitution united these two parts of the judiciary and placed them both under state control. 
The 1964 Constitution also changed the composition of the legislature to include the Wolesi Jirga (Lower House) and the Meshrano Jirga (Upper House). The members of the Wolesi Jirga were elected by universal adult franchise for four years. One third of the members of the Meshrano Jirga were appointed by the king, another third elected by the Provincial Council, and the remaining third appointed by the Chairman of the Provincial Jirga. Both houses were required to pass a bill before it became law.

\section{Constitution of 1964 - Selected Provisions}

\section{Preamble}

In the Name of God the Almighty and the Just

To reorganize the national life of Afghanistan according to the requirements of the time and on the basis of the realities of national history and culture;

To achieve justice and equality;

To organize the functions of the State and its branches to ensure liberty and welfare of the individual and the maintenance of the general order;

To achieve a balanced development of all phases of life in Afghanistan; and

To form, ultimately, a prosperous and progressive society based on social co-operation and preservation of the human dignity.

\section{Article 1}

Afghanistan is a Constitutional monarchy; an independent, unitary, and indivisible state. Sovereignty in Afghanistan belongs to the Nation. The Afghan Nation is composed of all those individuals who possess the citizenship of the state of Afghanistan in accordance with the provisions of the law. The word Afghan shall apply to each such individual.

\section{Article 2}

Islam is the sacred religion of Afghanistan. Religious rites performed by the state shall be according to the provisions of the Hanafi doctrine. Non-Muslim citizens shall be free to perform their rituals within the limits determined by laws for public decency and public peace.

\section{Article 7}

The King is the protector of the basic principles of the sacred religion of Islam, the guardian of Afghanistan's independence and territorial integrity, the custodian of the Constitution and the centre of its national unity.

\section{Article 15}

The King is not accountable and shall be respected by all.

\section{Article 25}

The people of Afghanistan, without any discrimination or preference, have equal rights and obligations before the law.

\section{Article 26}

No deed is considered a crime except by virtue of a law in force before its commission. 
Every Afghan is entitled to travel within the territory of his State and settle anywhere except in areas prohibited by the law.

\section{Article 29}

Property is inviolable. No one's property can be confiscated except in accordance with the provision of the law and the decision of a competent court.

\section{Article 31}

Freedom of thought and expression is inviolable.

\section{Article 34}

Education is the right of every Afghan and shall be provided free of charge be the state and the citizens of Afghanistan.

\section{Article 41}

The Shura in Afghanistan manifests the will of the people and represents the whole of the nation.

\section{Article 85}

The Government of Afghanistan consists of the Prime Minister and the Ministers.

\section{Article 89}

The government shall be formed by the person designated as Prime Minister by the King.

\section{Article 97}

The judiciary is an independent organ of the state and discharges its duties side by side with the legislative and executive organs.

\section{Article 98}

The Judiciary consists of a Supreme Court and other courts, the number of which shall be determined by law. It is within the jurisdiction of the Judiciary to adjudicate all litigations brought before it according to the rule of law, in which real or legal persons, including the State, are involved as either plaintiff or defendant.

\section{Article 102}

The courts in the cases under their consideration shall apply the provisions of this Constitution and the laws of the state. Whenever no provision exists in the Constitution or the laws for a case under consideration, the court shall, by following the basic principles of the Hanafi jurisprudence of the Shari'a of Islam and within the provisions set forth in this Constitution, render a decision that in their opinion secures justice in the best possible way.

The ambitious constitution and the parliamentary elections that followed were criticized as irrelevant to the lives of many citizens of Afghanistan, who were uneducated about the new concepts in the constitution. The parliament was given the ability to legislate to effectuate the new principles in the constitution, but they were without the support of the people. As a result, Dr. Yousuf was driven from office by protests that culminated in the shooting of three protesting students outside his home. 
Subsequently, Dr. Mohammad Hashim Maiwandal was appointed prime minister, a position he occupied until the overthrow of the monarchy. The period of 1965 to 1973 was the most productive in the legal history of Afghanistan in terms of codification and centralization. This period witnessed the culmination of the codification process started by Daoud and the writing of the criminal code, civil code, and criminal procedure code. Much of the modern law of Afghanistan, which is still relevant and in force today, was passed by the parliament during this time. Comprehensive criminal codes were passed with definitions of crimes and punishments and the judicial system was, for the most part, regularized. The legal system during this period most closely reflects the current modern legal structure of Afghanistan, and many of the laws passed then remain on the books today.

In 1973, Daoud, supported by elements of the Marxist groups in Afghanistan, overthrew King Zahir Shah, abolished the monarchy, and named himself the prime minister. Daoud formed a Central Committee to advise him, yet he ruled via decree with absolute power over the government until he established a new constitution in 1977. Daoud's major initiative during this period was to install a system of land redistribution, with compensation to be paid by the government, to expand the reach of private property. In January 1977, the Loya Jirga was called to adopt the new constitution, and on February 24, 1977, Daoud proclaimed the new constitution.

This constitution differed from earlier incarnations. Its two major innovations were the explicit mention of the rights of women and the recognition of the right of every citizen to vote. The role of religion in the constitution was also diminished, as there was no mention of the Hanafi school of Islamic jurisprudence as the official religion. Overall, the constitution reflected the socialist ideology of the time. Indeed, Articles 17 and 18 encouraged government regulation of the economy and Article 13 nationalized all natural resources of the state.

\section{Constitution - Selected Provisions Fundamental Principles}

\section{Article 1}

The defense of independence, national sovereignty, and territorial integrity.

\section{Article 2}

The exercise of power by the People, the majority of whom consists of farmers, workers, the enlightened people, and the youth.

\section{Article 13}

Resources such as mines, forests and energy, large industries, communications, important air and surface transport establishments, ports, banks, insurance important food procurement establishments, and archaeological and historical objects are part of the national property and their administration shall belong to the state, in accordance with the provisions of the law.

\section{Article 14}

Limits on agricultural property shall be determined and fixed by the land reform law. 


\section{Article 15}

Private property and enterprises, based on the principles of non exploitation shall be regulated by law.

\section{Article 22}

The religion of Afghanistan is the sacred religion of Islam. Those citizens who are not followers of Islam shall be free to perform their religious rites within the limits determined by the laws relating to public decency and public peace.

\section{Article 27}

All the People of Afghanistan, both women and men, without discrimination and privilege, have equal rights and obligations before the law.

\section{Article 29}

Every Afghan who attains the age of eighteen has the right to vote in accordance with the provision of the law.

\section{Article 48}

The Meli Jirga of Afghanistan is where the will of the People is manifested and it represents the whole of the Nation.

\section{Article 49}

Members of the Meli Jirga, 50 percent of whom shall be composed of farmers and workers, are nominated by the party and shall be elected by the people in accordance with the provisions of the law for a period of 4 years through free universal, secret and direct elections. For this purpose, Afghanistan shall be divided into electoral constituencies. The number and the size of the constituencies shall be determined by law.

\section{The Communist Period and the Civil War}

The 1977 Constitution never entered into force because, on April 27, 1978, a coup was launched against the Daoud government. Soon after the coup, the Revolutionary Council of the People's Democratic Republic of Afghanistan was formed as the new government, headed by Nur Muhammad Taraki, which was soon replaced by a Soviet-style politburo. This government ruled by decree rather than through the legislature, with decrees emanating from the central planning committee without representation of the people.

The Third Decree on April 30, 1978 abolished the Daoud constitution. Subsequent decrees gave equal rights to women (Decree Number 7) and ordered land reform (Decree Number 8). This land reform required the redistribution of about half of rural land to landless peasants. The decree on women's rights took a revolutionary stand, setting the marriageable age for a woman at 16 and setting an upper limit, 300 Afghanis, on the money payable to a wife in the case of the dissolution of a marriage ( $m a h r)$. Another decree required that each person over a certain age learn to read within one year, a policy that was highly resented in the countryside. 
This period involved a rewriting of the existing law of Afghanistan through the communist politburo, although most of the criminal code written during the Daoud presidency was still used to prosecute crime. The newly formed secret police of the communist regime strictly enforced this new law. Any person who broke the law or resisted enforcement of the law was subject to summary imprisonment.

In December 1979, the Soviet Union invaded Afghanistan. The USSR, which had coordinated the invasion with leading Afghan Marxist Babrak Karmal, assassinated President Hafezullah Amin and installed Karmal as the president of the country.

In 1980, the Revolutionary Council issued a provisional constitution, the Fundamental Principles of the Democratic Republic of Afghanistan. Article 36 named the Revolutionary Council as the sole governing institution in the country. This constitution reintroduced official recognition of religion into the constitution. Article 5 outlined the role of Islam in the new government:

Respect, observance, and preservation of Islam as a sacred religion will be ensured in the Democratic republic of Afghanistan and freedom of religious rites guaranteed for Muslims. Followers of other faiths will also enjoy full freedom of religious practice as long as they would not threaten the tranquility and security in society. No citizen is entitled to exploit religion for anti-national and anti-people propaganda or other actions running counter to the interests of the Democratic republic of Afghanistan. The government will help the clergy and religious scholars in carrying out their patriotic activities, duties and obligations.

Religion, overall, was given more deference than in the preceding years. Indeed, during the earlier communist period, the enmity to religion was so fierce that individuals who attempted to practice their religion by going to the mosque or praying were subject to abuse. However, the 1980 Constitution represents the only time in the constitutional history of Afghanistan that Islam was not recognized as the official religion of the country in a constitutional document.

Almost all governing institutions were remade during this period, including the remodeling of compulsory education in the soviet method with required classes in Russian, as part of the general sovietization of the country. Religious instruction was supplemented with instruction on communist ideology. High school students of the time recall constant pressure from their teachers and peers to join the communist party and inform on those who were not communist. In general, law was modeled on soviet institutions and lawmaking. Local governance was emphasized with a hybrid of the local soviet and the jirga introduced. These local jirgas were supposedly responsible for local economic, political, and social administration; in fact, however, these local organs were required to receive the approval of the central authorities, in effect giving the local jirgas very little control. 


\section{Fundamental Principles of the Democratic Republic of Afghanistan of 1980 - Selected Provisions}

\section{Article 1}

The Democratic Republic of Afghanistan is an independent, democratic state belonging to all Moslem working people of Afghanistan ranging from workers, peasants, nomads and the intelligentsia to other toilers and the entire democratic and patriotic forces from all nationalities, tribes and clans of the country.

\section{Article 4}

The People's Democratic Party of Afghanistan, the part of the working class and all the toilers of the country, will be the mobilizing force of society and state, reflecting the will and interest of workers, peasants, the intelligentsia, all the toilers and national democratic forces and a steadfast advocate of the real interest of the entire peoples living in our singular homeland, Afghanistan.

\section{Article 11}

The Democratic Republic of Afghanistan will expand and strengthen its friendship and traditional all-out cooperation with the Soviet Union and its cooperation and friendly relations with other countries of the socialist alliance on the basis of international solidarity.

\section{Article 17}

Ownership exists in the Democratic Republic of Afghanistan in the form of public property which is shared by all, private cooperatives and personal ownership.

\section{Article 36}

Until conditions are ripe for free and secure election of delegates to the Loya Jirga, the Revolutionary Council will act as the highest organ of state power in the Democratic Republic Of Afghanistan.

Karmal was soon replaced by Dr. Najibullah to help calm the growing insurgency against the communist government. In January 1987, Najibullah formed the Extraordinary Commission for National Reconciliation to draft a new constitution.

In November 1987, the Loya Jirga adopted a new constitution. It established a multiparty state with a legislature for which elections were held in early 1988. Further, Article 2 of the constitution named Islam as the official religion of the state and, like the 1931 Constitution, stated that no law shall be made that is contrary to its dictates. There was also a formal legislature in the 1987 Constitution, but all lawmaking authority was concentrated in the politburo. The judiciary was to make its decisions in accordance with the law; however, this constitution did not specify whether that law was the codified law of the state or of the Shari'a. 


\section{Constitution of 1987 - Selected Provisions}

\section{Article 2}

The sacred religion of Islam is the religion of Afghanistan. In the Republic of Afghanistan no law shall run counter to the principles of the sacred religion of Islam and other values enshrined in this constitution.

\section{Article 77}

The National Assembly is the highest legislative organ of the republic of Afghanistan.

\section{Article 108}

Judgment in the Republic of Afghanistan shall be delivered only by a court in accordance with the law.

Facing a rising tide of mujahedeen attacks against the government, the Soviet Union completed its withdrawal from Afghanistan, pursuant to the Geneva Accords, on February 15, 1989. Najibullah, the Soviet backed president, remained in power and in control of the country until 1992, although his followers were now a minority in the legislature.

In 1992, an interim government was formed to lead the Islamic State of Afghanistan. This state was, however, a state in name only, as the interim government could barely exercise control over the city of Kabul. When Burhan al-Din Rabbani seized executive power, he introduced a new constitution in 1992, the Constitution of the Islamic State of Afghanistan. Departing from all previous constitutions, the 1992 Constitution stated that the state was based on the Koranic verse and sovereignty of the state belonged to God. This contrasted with the 1964 Constitution, which stated that the sovereignty of the state rested in the people. The 1992 Constitution also envisaged no role for codified law in the governing of society and the adjudication of disputes. Instead, the law was given solely by an extremist interpretation of the Shari'a. The government of the country was through three executive bodies: the President, the Leadership Council, and the Jihadi Council. This constitution was never put into force because of the degree of disarray and anarchy existing within the government of Afghanistan in 1992. The official government in Kabul had no control over the rest of the country and battles were being fought between different tribal groups to win control over the government.

\section{Draft Constitution of 1992 - Selected Provisions}

\section{Article 1}

Afghanistan is an unbreakable unit of the independent Islamic State.

\section{Article 2}

The system of the Islamic State of Afghanistan will be based on the provisions of the Holy Quran.

\section{Article 3}

In the Islamic State of Afghanistan, laws governing political, social, cultural, and economic aspects will be made in conformity with the tenets and principles of Islam. 


\section{Article 7}

The Sharia courts will decide cases according to the Hanafite creed.

\section{Article 36}

Until conditions are ripe for free and secure election of delegates to the Loya Jirga, the Revolutionary Council will act as the highest organ of state power in the Democratic Republic Of Afghanistan.

As the civil war continued, another movement began to win battlefield victories and capture many towns outside of Kabul. In 1994, the Taliban were created by a group of religious students who were tired of the endless suffering caused by the in-fighting between mujahedeen groups, the general insecurity in the country, and the kidnapping of women. Led by Mullah Mohammed Omar, the Taliban attracted the support of many refugees and religious students and were financed, reportedly, by the United States, Pakistan, and Saudi Arabia. By September 1996, Kabul had fallen and the Taliban controlled the majority of Afghanistan. Subsequently, the Taliban set up their government in Kabul and Kandahar. Mullah Omar presided over the Supreme Shura. The Taliban professed that their government aimed to free Afghanistan of corruption and to create a pure society in accordance with Islamic principles.

At the beginning of Taliban rule, the government relentlessly rooted out corruption and established law and order. In this they were successful, as the cycle of fighting between mujahedeen was stopped in many parts of the country and trucking routes into and throughout Afghanistan were reopened. However, these goals came at the expense of the creation of a fully staffed modern governing structure. The former institutions of the state, the ministries, schools, and other public services, withered.

To govern through the Shuras established in Kandahar and Kabul, the Taliban established an Islamic state with rule by edict based on a radical interpretation of Shari'a law. These edicts controlled most aspects of life, from the clothes that a woman was to wear, to the length of a man's beard, to appropriate family activities. These edicts and decrees were posted all around Kabul and Kandahar so that people could be aware of the requirements. The religious edicts were enforced, sometimes through violence, by the Department for the Promotion of Virtue and the Prevention of Vice.

During this period, women had virtually no rights. Girls were unable to attend public school, and foreign aid to the country became minimal amid a flurry of Taliban edicts aimed at driving out foreign NGO workers. For example, on July 10, 2000, the Taliban government issued an edict requiring that all foreign aid organizations fire their female Afghan employees. Law was enforced sporadically and unequally. There was little written law and few formal legal processes, such as regularized trials.

\section{Edict of General President of the Religious Police - Kabul, DeCEMber 1996}

1. To prevent sedition and the uncovering of women. No drivers are allowed to pick up women who are wearing the Iranian burqa. In case of a violation the driver will be imprisoned. If women 
in such dress are observed in the street, their house will be found and their husband punished. If the women wear stimulating and attractive clothing and are without a male relative with them, drivers should not pick them up.

2. To prevent music. To be broadcasted by the public information resources. In shops, hotels, vehicles and rickshaws, cassettes and music are prohibited. This matter should be monitored within five days. If any music cassette found in a shop, the shopkeeper should be imprisoned and the shop locked. If five people guarantee the shop should be opened the criminal released later. If a cassette is found in the vehicle, the vehicle and the driver will be imprisoned. If five people guarantee the vehicle will be released and the criminal released later.

3. To prevent beard shaving and its cutting. After one and a half months if anyone is observed to have shaved or cut his beard, he shall be arrested and imprisoned until his beard grows.

4. To prevent keeping pigeons and playing with birds. Within ten days this habit and hobby should stop. After ten days this should be monitored and the pigeons and any other playing birds should be killed.

5. To prevent kite-flying. The kite shops in the city shall be abolished.

6. To prevent idolatry. In vehicles, shops, hotels, museums and any other place pictures and portraits should be abolished. The religious police shall tear up all pictures in the above places.

7. To prevent gambling. In collaboration with the security police, the main gambling centers should be found and the gamblers imprisoned for one month.

8. To eradicate addiction. Addicts should be imprisoned and investigation made to find the supplier and the shop. The shop should be locked and the owner and user should be imprisoned and punished.

9. To prevent British and American hairstyles. People with long hair shall be arrested and taken to the Religious Police department to shave their hair. The criminal has to pay the barber.

10. To prevent interest on loans, charge on changing small denomination notes and charge on money orders. All money exchangers should be informed that the above three types of exchanging the money should be prohibited. In case of violation criminals will be imprisoned for a long time.

11. To prevent washing clothes by girls and women along the water streams in the city. Violating ladies shall be picked up with respectful Islamic manner, taken to their houses and their husbands severely punished.

12. To prevent music and dances in wedding parties. In the case of violation the head of the family will be arrested and punished. 
13. To prevent the playing of music drum. The prohibition of this should be announced. If anybody does this then the religious elders can decide the punishment.

14. To prevent sewing ladies clothing and taking female body measurements by a tailor. If women or fashion magazines are seen in the shop the tailor should be imprisoned.

15. To prevent sorcery. All the related books should be burnt and the magician should be imprisoned until his repentance.

16. To require prayer in a mosque. Prayer should be done on their due times in all districts. Transportation should be strictly prohibited and all people are obliged to go to the mosque. If young people are seen in the shops they will be immediately imprisoned.

\section{The Creation of the Current State}

The situation in Afghanistan remained unsettled between 1998 and 2001. In some areas the Taliban held control and ruled through edicts such as the one above, while other parts of the country remained outside Taliban control and the civil war continued. Military commanders conducted dispute resolution and governance in those areas.

Prompted by the September 11, 2001 terrorist attacks on the United States, the United States and other nations invaded Afghanistan in October 2001. By November 2001, United States troops allied with fighters of the Northern Alliance had captured control of the country. To begin the reconstitution of the legal system, leaders of Afghanistan and the international community met in Bonn, Germany in November 2001. On December 5, 2001, the Bonn Agreement for the Transitional Administration of Afghanistan was concluded. It laid out the process through which Afghanistan would form a new government and write a constitution. As part of the agreement, Hamid Karzai was named interim president of Afghanistan and a 30member Interim Administration was selected. On December 22, 2001, the Interim Administration and President Karzai took the oath of office. The Bonn Agreement also called for the convening of the Loya Jirga and the writing of a new constitution. The full text of the Bonn Agreement is included in your statutory supplement.

\section{BONN AGREEMENT - INTRODUCTORY LANGUAGE}

The participants in the UN Talks on Afghanistan,

In the presence of the Special Representative of the Secretary-General for Afghanistan,

Determined to end the tragic conflict in Afghanistan and promote national reconciliation, lasting peace, stability and respect for human rights in the country,

Reaffirming the independence, national sovereignty and territorial integrity of Afghanistan,

Acknowledging the right of the people of Afghanistan to freely determine their own political future in accordance with the principles of Islam, democracy, pluralism and social justice, 
Expressing their appreciation to the Afghan mujahidin who, over the years, have defended the independence, territorial integrity and national unity of the country and have played a major role in the struggle against terrorism and oppression, and whose sacrifice has now made them both heroes of jihad and champions of peace, stability and reconstruction of their beloved homeland, Afghanistan,

Aware that the unstable situation in Afghanistan requires the implementation of emergency interim arrangements and expressing their deep appreciation to His Excellency Professor Burhanuddin Rabbani for his readiness to transfer power to an interim authority which is to be established pursuant to this agreement,

Recognizing the need to ensure broad representation in these interim arrangements of all segments of the Afghan population, including groups that have not been adequately represented at the UN Talks on Afghanistan,

Noting that these interim arrangements are intended as a first step toward the establishment of a broad-based, gender-sensitive, multi-ethnic and fully representative government, and are not intended to remain in place beyond the specified period of time,

Recognizing that some time may be required for a new Afghan security force to be fully constituted and functional and that therefore other security provisions detailed in Annex I to this agreement must meanwhile be put in place,

Considering that the United Nations, as the internationally recognized impartial institution, has a particularly important role to play, detailed in Annex II to this agreement, in the period prior to the establishment of permanent institutions in Afghanistan.

On July 11, 2002, former King Zahir Shah convened the Loya Jirga that reconfirmed Hamid Karzai as president by a vote of 1,295 to 280. The Loya Jirga also agreed that a new constitution would be written by January 2004. That constitution-which created three equal branches of government (the executive, legislative, and judicial) and professed equal rights for all individuals-was adopted by the Loya Jirga in January 2004. The 2004 Constitution is the current constitution of Afghanistan and will be discussed in detail in Chapter II.

Elections were held for the legislative and executive branches in 2004 and 2005, and President Karzai was officially elected the president of the Islamic Republic of Afghanistan with 55 percent of the vote. Over one million citizens of Afghanistan voted in the election.

Law in this period is the law adopted by the legislative branch, although a confusing array of former law still exists, especially from the period between 1965 and 1973. The judicial branch, notably the Supreme Court, interprets the law. The law is enforced by a professional police force. The current institutions and actors in the law of Afghanistan are discussed in Section II of Chapter 2. 


\section{Discussion Questions}

Now that you know more about the legal history of Afghanistan, are you surprised to see how many different forms of government Afghanistan has had? Or how many constitutions it has been governed by? How different the constitutions are? What two constitutions struck you as the most different? How have previous versions influenced the current constitution?

\section{THE RULE OF LAW - AN OVERVIEW}

Turning from the specifics of Afghanistan's legal history, this section introduces concepts surrounding the rule of law, starting with a definition of the phrase itself. The history of Afghanistan's constitutions was itself a discussion of the rule of law, as it concerned the different legal regimes within the country since the 1880s. This section, however, looks at the rule of law from a more theoretical perspective. It also follows a different format than the rest of the chapter in that it uses original academic works to help illuminate the concepts with short introductions to put them in context. These works represent a variety of opinions.

\section{Reading Focus}

As you read these excerpts on the rule of law, ask yourself which of these viewpoints you think is most correct in its view of the rule of law and why.

\section{What is Law?}

Law, broadly defined, is a series of rules, often enforced by institutions, which govern the behavior of individuals in society. Law reaches businesses, individuals, families, and organizations in society and structures how they are able to function. However, law need not be the formal rules passed by the legislature. Law can also be unwritten but nevertheless enforced by the expectations of a community. Such informal rules are still law because individuals in the community are expected to behave a certain way, and when they fail to meet that standard, they are held to account by the community, either through punishment or other methods such as loss of trust. In essence, law defines the parameters of acceptable behavior.

Laws are not the same as social norms. Social norms are the expectations of a certain social group that are enforced by that group. Norms can be just as binding and can exact the same amount of punishment when they are broken, yet they are not law. Law is different than norms because it is accepted across a coherent grouping, such as a state or a town, whereas norms are applicable through social convention to a less identifiable grouping. An example of a social norm would be that parents expect their children to live with them until they are 18 years old and to help out around the house. If the children do not do that, they are punished by their parents. However, this is not a law and instead is a norm enforced in a social group. 
In excerpts below, Brian Tamanaha, the U.S. Department of State, and the Afghanistan Human Development Report offer possible definitions of "the rule of law." Mr. Tamanaha defines the rule of law narrowly, while the State Department takes a broader view, requiring more indicators of the rule of law. The Report offers the broadest definition, including all institutions that promote justice.

\section{Brian Tamanaha - A Concise Guide to the Rule of Law \\ St. John's University School of Law: Legal Research Paper Series, September 2007, <http://ssrn.com/abstract=1012051>}

\section{A. Rule of Law Narrowly Defined}

The rule of law, at its core, requires that government officials and citizens are bound by and act consistent with the law. This basic requirement entails a set of minimal characteristics: law must be set forth in advance (be prospective), be made public, be general, be clear, be stable and certain, and be applied to everyone according to its terms. In the absence of these characteristics, the rule of law cannot be satisfied.

\section{B. Two Functions of the Rule of Law}

One function of the rule of law is to impose legal restraints on government officials, in two different ways: A) by requiring compliance with existing law; and B) by imposing legal limits on lawmaking power. The first type of legal restraint is that government officials must abide by valid positive laws in force at the time of any given action. The second type of legal restraint imposes restrictions on the law itself, erecting limitations on the law making power of the government. Under this second type of restraint, certain prohibited actions cannot be legally allowed, even by a legitimate lawmaking authority.

A second function of the rule of law is to maintain order and coordinate behavior and transactions among citizens. People must generally behave in a fashion that does not breach legal rules. Transgressions of legal rules or social disruptionswhether treated as criminal or civil (societies draw different lines)—will provoke a response from legal institutions charged with enforcing legal requirements and resolving disputes consistent with applicable legal norms.

\section{Discussion Question}

What is the most important component of the rule of law for Tamanaha? Is it the existence of a set of written laws? That people obey those laws? That people trust the government to obey those laws? 


\section{United States State Department - Rule of Law Broadly Defined \\ < http://usinfo.state.gov/dhr/democracy/rule_of_law.html>}

The rule of law is a fundamental component of democratic society and is defined broadly as the principle that all members of society - both citizens and rulers - are bound by a set of clearly defined and universally accepted laws. In a democracy, the rule of law is manifested in an independent judiciary, a free press and a system of checks and balances on leaders through free elections and separation of powers among the branches of government.

\section{Afghanistan Human Development Report \\ Bridging Modernity and Tradition: Rule of Law and the Search for Justice}

Center for Policy and Human Development, (2007).

For Afghans, the rule of law refers to all those state and non-state institutions that promote justice and human development through the application of public rules that are deemed fair, applied independently, enforced equally and consistent with human rights principles. The definition of the rule of law in Afghanistan consists of four major dimensions: 1) independence of rule of law institutions, 2) public and fair laws, 3) equal enforcement, and 4) consistency with human rights principles.

The main formal justice and law enforcement institutions in Afghanistan include the judiciary, Attorney General's Office, the Ministry of Justice, the Police, and the National Assembly. Informal and non-state institutions of dispute resolution are also prominent and include jirgas/shuras, Community Development Councils, other civil society groups, and individuals that provide mediation and arbitration services.

Education and watchdog organizations, such as the Afghanistan Independent Human Rights Commission and those within the media and civil society, also play a vital role in promoting the rule of law. Most of these institutions are active in providing alternative dispute resolution services in Afghanistan.

\section{AdDitional Conceptions of the RULe of LAW}

\section{United Nations}

A principle of governance in which all persons, institutions, and entities, public and private, including the State itself, are accountable to laws that are publicly promulgated, equally enforced and independently adjudicated, and which are consistent with international human rights norms.

\section{The World Bank}

Without the protection of human and property rights, and a comprehensive framework of laws, no equitable development is possible. A government must ensure that it has an effective system of property, contract, labor, bankruptcy, commercial codes, personal rights laws, and other 
elements of a comprehensive legal system that is effectively, impartially, and cleanly administered by a well-functioning, impartial and honest judicial and legal system.

\section{The European Union}

The primacy of law is a fundamental principle of any democratic system seeking to foster and promote rights, whether civil or political, or economic, social and cultural. This entails means of recourse enabling individuals to defend their rights. . . The principle of placing limits on the power of the State is best served by a representative government drawing its authority from the sovereignty of the people. The principle must shape the structure of the state and the prerogatives of the various powers.

\section{United States Agency for International Development}

The rule of law ensures that individuals are subject to, and treated equally according to the law, and that no one is subject to arbitrary treatment by the state. A rule of law that contributes to the building of sustainable democracy is one that protects basic human rights. . . It is one in which market based economic activity is enabled, and freely operates. It is on in which the processes and institutions of justice are available to all individuals. A democratic rule of law is also one in which the processes and institutions of justice work efficiently and effectively to establish justice and resolve disputes.

\section{Discussion Questions}

1. Are all of these conceptions of what is the rule of law saying the same thing? How are they different or the same?

2. Is there one of these points of view from all of the definitions of the rule of law you have read that you agree with most?

These next two excerpts, from Brian Tamanaha and Erik Jensen, try to answer the question of what are the benefits of the rule of law. Before reading the article, can you list what some benefits of the rule of law could be?

\section{Brian Tamanaha - A Concise Guide to the Rule of Law}

St. John's University School of Law: Legal Research Paper Series, September 2007, <http://ssrn.com/abstract=1012051>

\section{A. Primary Benefits of the Rule of Law, and Problems in Connection with Each Benefit}

Enhances certainty, predictability, and security in two arenas: between citizens and the government (vertical), and among citizens (horizontal).

With respect to the government, citizens benefit by being apprised in advance of the government's likely response to their actions. This is an important aspect of liberty, whereby citizens know the full range of conduct they can engage in 
without fear of being subjected to government interference or sanction. Anything not prohibited by the law can be done by the citizen without fear.

With respect to fellow citizens, people are able to interact with one another knowing in advance the rules that will be applied to their conduct should a problem or dispute occur. Such predictability furthers their ability to make choices and to engage in conduct with others.

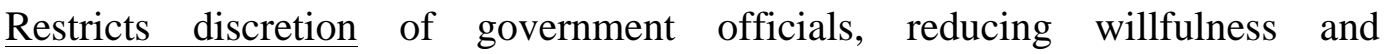
arbitrariness.

A common worry of citizens is that government officials may be unduly influenced in their government actions by inappropriate considerations-by prejudice, by whim, by arbitrariness, by passion, by ill will or a foul disposition, or by any of the many factors that warp human decision making and actions. The rule of law constrains these factors by insisting that government officials act pursuant to and consistent with applicable legal rules.

A peaceful social order is maintained through legal rules.

A peaceful social order is marked by the absence of routine violence, and by the presence of a substantial degree of physical security and reliable expectations about surrounding conduct. These are the minimal conditions necessary for a livable social existence.

Economic development is facilitated by certainty, predictability, and security, for two basic reasons.

As indicated at the outset, the rule of law enhances certainty, predictability, and security. In addition to enhancing liberty, it is widely thought that market-based economic systems benefit from these qualities in two different respects, the first related to contracts and the second to property.

First, economic actors can better predict in advance the anticipated costs and benefits of prospective transactions, which enables them to make more efficient decisions. One can enter into a contract with some assurances of the consequences that will follow if the other party fails to live up to the terms of the contract. Second, the protection of property (and persons) conferred by legal rules offers an assurance that the fruits of one's labor will be protected from expropriation by others.

Fundamental justice is the requirement that the rules must be applied equally to everyone according to their terms.

The equality of application of law, an aspect of the rule of law, is a component of fundamental justice. It is widely considered unfair and unjust when the identity or 
status of a person affects how legal officials apply or interpret the law. No one should be unduly favored or ill-treated by legal officials.

\section{Discussion Question}

Which of the benefits identified by Tamanaha do you think is the most important? Least important? Why do you think so?

Erik Jensen - Justice and the Rule of Law

Ed. Charles Call, Building States to Build Peace

(New York: Lynne Reinner, 2008)

Five of the most commonly articulated goals in donor-assisted rule of law programs are to improve citizen security and stability, dispute resolution, economic growth and development, protection of human rights, and protection from bureaucratic caprice and corruption.

\section{A. Security and Stability}

State-building requires a state. If institutions are to strengthen security credibly, they must act with some restraint. Especially at the early state-building phase, one of the most consequential tasks is distinguishing between good and bad actors within security forces. Moreover, if institutional incentives to encourage good behavior are not implemented, the result will be varying degrees of poor or inimical performance.

\section{B. Protecting Human Rights}

In the practice of development, the desirability of representative government and importance of maximum rights and participation is assumed. All of the challenges that attend formal legal institution building discussed in this paper suggest that a generalized rights-based approach is ill-advised. A more nuanced approach with a higher likelihood of success would ask and answer three questions: Which human rights/crimes are the highest priority and violation most serious? Are there ways to modify the functions of pre-existing institutions to address the rights violation/crime? If not, can formal institutions effectively target the rights violations identified?

\section{Settling Common Disputes}

Beyond the security-on-the-one-hand-justice-on-the-other debate is a wide, and largely ignored, swath of disputes that citizens may care the most about after basic security: that is, small debt, small property, small inheritance and family matters. Apart from assessing which functions matter the most and which configuration across institutions might deliver those functions, a realistic assessment of change potential within institutions is necessary. Which changes can be made relatively 
easily and which will face more resistance? Which changes are most essential to build the legitimacy of the state? And will the benefits of progress on the dependent variable justify the costs?

\section{Promoting Economic Growth and Development}

A convincing argument could be made that, after citizen security and stability, the most important rule of law priority should be the facilitation of economic growth. Political development tends to follow economic development, the consequent expansion of the middle classes and their rising political demands. In other words, get economic growth going, rapid economic growth if you can; the middle classes will then expand and demand a reduction in the scope of the patrimonial state among other positive political benefits.

\section{E. Combating Corruption}

Many rule of law projects assume that institutional support for formal rule of law institutions will translate into less corruption. A closely associated assumption is that an independent judiciary must fulfill the functional need for credible third party enforcement. Private enforcement, contracting out enforcement and citizen enforcement are alternative methods to public enforcement. Citizen enforcement through easy public access to information on public programs can serve to create demand for transparency, monitor service quality and challenge abuse by public officials.

\section{Discussion Question}

Jensen argues that the ability to settle common disputes is one of the benefits of the rule of law. Do you believe that a codified system of formal dispute resolution through the courts would be beneficial to Afghanistan? Why or why not?

This next excerpt from Douglas Ramage reports on a particular example of the benefits of the rule of law, using the case study of Indonesia. With a population of more than 234 million spread across over 17,000 islands, Indonesia is the most populous Muslim country in the world.

On September 30, 1965, the democratically-elected communist government of President Sukarno was overthrown by a military coup involving the palace guard and some military forces of Indonesia. General Suharto was installed as president, where he ruled over an authoritarian government until 1998. Once in power, General Suharto consolidated control over his personal political party and the military. Many opposition supporters and former communists were imprisoned or executed. Suharto engaged in the serious repression of the East Timorese population within the country.

Beginning in 1996, Indonesian citizens began to publicly demand change, culminating in mass demonstrations and riots in 1998. Further, the nations of the world began to scrutinize Indonesia's human rights record more closely as Suharto used force to suppress the 
demonstrations. In response, Suharto stood for reelection by the Indonesian parliament, which endorsed him.

However, Indonesian students were unsatisfied with this result and occupied the parliament until Suharto was forced to turn over power to his vice president. Democratic elections were held in 1999 and again in 2004.

Since the end of governance by Suharto, Indonesia has undergone a transformation from an economically struggling country with little infrastructure to a successfully developing state. The article by Ramage below focuses on changes that have occurred since 1998.

\section{Douglas E. Ramage - A Reformed Indonesia Australian Financial Review, October 12, 2007}

Formally separated from the armed forces just four years ago, the police have begun to demilitarize training and end the systemic brutalizing of cadets in the police academy (which was part of the Soeharto-era curriculum intended to make the police "tough"). The changes are dramatic in the National Police Academy, or Akpol, in Semarang, Central Java. Akpol's commanders did not merely replace the old militarized curriculum with dry text books on international human rights standards. Instead, cadets are taught by young human rights trainers from Jogjakarta's Islamic University of Indonesia.

In just a few years, the Indonesian National Police efforts to implement new approaches to "community oriented policing" are starting to reduce crime and improve the image of the police. In two precincts in Jogjakarta alone crime rates plunged 25 percent after the police began listening to the communities they serve, and responding to their complaints.

While young Akpol cadets were studying human rights and community policing in Semarang last July, in Jakarta the notorious Customs Office at the country's largest port, Tanjung Priok, was being cleaned up. The Finance Minister with backing by the President is overhauling the Customs Office; over 1300 Customs Office civil servants in the inefficient and highly corrupt port were transferred. Just 800 new ones took their place. Subsequent civil service reforms included a doubling of salaries and the introduction of merit-based performance measurements.

In the first month of reforms, the much smaller customs force at the Tanjung Priok port increased inspection and X-raying of containers from 500 a month to over 2500. In one fell swoop this civil service reform tackled endemic corruption, stimulated exports, and burnished the reform credentials of the government.

The thread running between human rights education at Akpol and a hard hitting clean-up of the infamously corrupt customs service is that they both represent genuine reform. These efforts by Indonesia's democratic government to improve 
services - in policing and customs - show Indonesians that the post-Soeharto era can indeed deliver the goods: free elections and concrete improvements in services to citizens. And these civil service reform efforts build on other reform initiatives in the judiciary, the attorney-general's office, and the tax department.

The new and positive consensus view of Indonesia is far more accurate than the panicked assessments of a few years ago. The Indonesian economy in 2007 is strengthening and opinion polls show Indonesians themselves think the country is in fairly good shape. Indonesia is enjoying its sixth straight year of economic expansion with growth in 2007 slated to reach 6.3 per cent. The macro-economy is sensibly managed by a highly competent economic team. With growth predicted to reach 6.8 per cent in 2008 , even 7 percent GDP growth rate is no longer unimaginable.

Indonesia's place today is the result of choices made by its people - voters and leaders alike. Since the fall of Suharto, the country has prioritized democratization, macroeconomic stability and growth rather than improved governance, better services, and micro-economic reform. And given the heavy national emphasis on consolidating a democratic electoral system, ie: getting elections right, it bears a closer look at just what all the millions of voters and hundreds of elections tell us about the new Indonesia.

Elections are now a permanent fixture of Indonesia, at both the national and local level, exemplified most by hundreds of city, district and provincial polls held in the last two years, embedding both choice and stirrings of genuine accountability, at the city and district level for the first time. The commitment of Indonesians to participation in elections can be seen in very high voter turnout, running between 60 percent and 70 percent - giving Indonesia one of the highest voter participation rates in the world (for countries that do not have mandatory voting).

Even more significant for Indonesia's democratic consolidation is how its own citizens view their personal and community security - an area of immense concern in the first few chaotic years after Suharto's fall. From 1998 to 2002, fears for personal safety and community security always topped the lists of citizen worries in virtually all national polls. In 2007 Indonesians report feeling generally safe and rarely cite security as a top worry.

\section{Discussion Questions}

1. Can you see any parallels between the situation in Afghanistan and that of Indonesia? Do you think that any of the successes that Indonesia has experienced since 1998 hold lessons for Afghanistan?

2. Reading this excerpt about Indonesia, do you really think that these changes were the result of the imposition of the rule of law or was there another cause? 
The final two excerpts in this section from Jensen and Fukuyama speak of the challenges and problems that confront any nation or people attempting to institute the rule of law. Each author focuses on the factors that can cause a new system of law to fail. Are they right? Can you think of any different factors?

Erik Jensen - Justice and the Rule of Law

Ed. Charles Call, Building States to Build Peace

(New York: Lynne Reinner, 2008)

\section{A. Surmounting Institution-Building Challenges}

While rule of law institutions have distinct challenges, they also broadly share common challenges to institution building: failure to take account of what institutions already exist, lack of prioritization of institution-building efforts, nontransferability of international models of capacity, and unintentional collateral damage caused to domestic institutions through the international presence.

\section{B. Institution Mapping and Dispute Mapping}

Central to the challenge of identifying which institution-building efforts to prioritize are concerns about public demand and need on the one hand, and legitimacy of institutions on the other. Institution mapping should capture preexisting practices, and avoid, to the extent possible, the introduction of inappropriate technology and forms that do not connect to prior local practice.

\section{Beyond Capacity Building: The Political Dynamics of Institutional Change}

Development strategies tend to start with a construction of perceived "political will" for change. Too often, the discussion of political will ranges from naive to disingenuous. Four key indices of change-potential in institution-building, including rule of law institutions, are the following: leadership, elite commitment (or at least lack of strong resistance), incentives of users and internal actors (including enforceable performance standards), and institutional competence.

\section{Mobilizing Constituencies}

Can more generalized public participation mobilize constituencies? The answer is yes, but only in targeted ways. Generally, domestic demand for public institutions and institutional reform is diffuse or weak because of classic collective action problems. One key way to mobilize constituencies is to couple rule of law activities with provision of essential services.

\section{E. Transplantation of Laws and Legal Institutions}

The long-run global historical experience with the transfusion of laws and evolution of legal systems is subtle and complicated. Since at least the times of 
the Romans, laws have been transplanted across borders. Transplantation of legal institutions often occurs at watershed moments of political change: installation or defeat/withdrawal of colonial powers, economic crisis, and importation by elite reformers who wish to modernize their country, or upon the demand or suggestion of international institutions.

The transplantation of laws and legal institutions is not always wrong, but formalistic transplantation should come with a caveat emptor. If law and legal institutions are adapted to local needs, they will be used and resources will be allocated to enforcing and developing them; and intermediary authorities can be more effective if they are working with a law that is broadly compatible with the pre-existing legal order.

\section{Francis Fukuyama - State Building}

(New York: Cornell University Press, 2004)

The majority of cases of successful state-building and institutional reform have occurred when a society has generated strong domestic demand for institutions and then created them out of whole cloth, imported them from the outside, or adapted foreign models to local conditions. If sufficient domestic demand exists, then supply usually follows, though the quality of that supply has varied.

Insufficient domestic demand for institutions or institutional reform is the single most important obstacle to institutional development in poor countries. Such demand when it emerges is usually the product of crisis or extraordinary circumstances that create no more than a brief window for reform. In the absence of strong domestic demand, demand for institutions must come from one of two sources. The fist consists of the various conditions attached to structural adjustment, program, and project lending by external aid agencies, donors, or lenders. The second is the direct exercise of political power by outside authorities.

There are thus grave limitations to the ability of external powers to create demand for institutions and therefore limitations on the ability to transfer existing knowledge about institutional construction and reform to developing countries. But the problem is in fact worse: The international community is not simply limited in the amount of capacity it can build; it is actually complicit in the destruction of institutional capacity in developing countries.

The contradiction in donor policy is that outside donors want both to increase the local government's capacity to provide a particular service like irrigation, public health, or primary education, and to actually provide those services to the end users. The latter objective almost always wins out because of the incentives facing the donors themselves. While many donors believe they can work toward both goals simultaneously, in practice the direct provision of services almost always undermines the local government's capacity to provide them once the aid program terminates. 


\section{Discussion Question}

Fukuyama makes two main points in this excerpt: (1) that it is difficult to transmit knowledge about institutions from the international community to a developing nation if there is no demand for institutions and (2) that the if international community, instead of building institutions domestically, chooses just to provide services directly to citizens, it can hurt the chance of institutions ever developing. Do you see either of these problems occurring in Afghanistan? In other words, do you think there is a demand for institutional and governance change in Afghanistan and do you think there are enough domestic institutions to support it?

\section{CONCLUSION}

This chapter has explored the legal history and legal traditions of Afghanistan. We'll next move to learning more about the current system and specific areas of law, but it is important to keep in mind how the threads of Afghanistan's past legal arrangements continue to influence the future. Further, now that the concept of rule of law is clearer, consider each area of law in the following chapters and analyze if the rule of law make solving legal problems more efficient, predictable, or fair. 


\section{Sources Consulted}

Ansari, M. A. Date unknown. The Constitutions of Afghanistan 1923-1996. Trans. Kabul: Shah M. Bookstore.

Center for Policy and Human Development. 2007. "Afghanistan Human Development Report." Constitution of Afghanistan of 1964.

Fukuyama, Francis. 2004. State Building. New York: Cornell University Press.

Grazda, Edward. 2000. Afghanistan Diary 1992-2000. New York: Powerhouse Books.

Grover, Verinder. 2000. Afghanistan Government and Politics. New Delhi: Deep \& Deep Publications.

"Islam and Constitutionalism in Afghanistan." Unpublished manuscript.

Jensen, Erik. 2008. "Justice in the Rule of Law." In Building States to Build Peace, edited by

Charles Call. New York: Lynne Reinner.

Kamali, Mohammad Hashim. 1985. Law in Afghanistan. Leiden: E.J. Brill.

Laber, Jeri and Barnett Rubin. 1985. Tears, Blood and Cries: Human Rights in Afghanistan

Since the Invasion. New York: U.S. Helsinki Watch Committee.

Marsden, Peter. 1985. The Taliban. Oxford University Press: Bangalore.

Mehroze Chishti, Nighat. 1998. Constitutional Development in Afghanistan. Karachi: Royal

Book Company.

Order No. 4913 of the President of the Islamic Transitional State of Afghanistan, Rules of

Procedure for the Constitutional Loya Jirga, November 2003

Ramage, Douglas E.2007. “A Reformed Indonesia.” Australian Financial Review.

Rasanayagam, Angelo. 2005. Afghanistan: A Modern History. London: I.B. Tauris.

Rashid, Ahmed. 2002. Taliban: Islam, Oil and the New Great Game in Central Asia. London: I.

B. Tauris \& Company.

Rotberg, Robert Ed. 2007. Building a New Afghanistan. Washington, DC: Brookings Institution Press.

Salim, Ahmad. 2006. Loya Jirga: The Afghan Grand Assembly. Lahore: Sang-E-Meel Publications.

Sufi, Juma Khan. 2005. Afghanistan: A Chronological Fact Sheet 1600-2004. Khost: Independent Cultural Society of Khost.

Tamanaha, Brian. 2007. "A Concise Guide to the Rule of Law." In St. John's University School of Law: Legal Research Paper Series. http://ssrn.com/abstract=1012051.

Tarzi, Amin. "Historical Relationship between State and Non-State Judicial Sectors in Afghanistan." Washington, DC: United States Institute of Peace.

"The Judicial State: Evolution and Centralization in the Courts of Afghanistan, 1883-1896." 2003. Unpublished Ph.D. dissertation. New York University.

Thier, Alexander. 2008. "A Third Branch? (Re) Establishing the Judicial System in Afghanistan." Building State and Security in Afghanistan. Vol. 2. Princeton: Liechtenstein Institute on Self-Determination. 


\section{CHAPTER 2: ACTORS AND INSTITUTIONS \\ IN THE CURRENT CONSTITUTIONAL SYSTEM}

\section{INTRODUCTION}

This chapter begins with a detailed discussion of the legal actors and institutions in Afghanistan. Articles of the current constitution are cited throughout this section as the foundational law for the actors and institutions discussed. Section III then introduces the typical role and necessary skills of a lawyer in Afghanistan's current legal system.

\section{Reading Focus}

Refer to your supplement and read the entire 2004 Constitution to familiarize yourself with the current law of Afghanistan.

Before discussing the current legal system in detail, this chapter looks briefly at some of the challenges facing Afghanistan's legal system. It is important to be aware of these challenges when evaluating the current system and thinking about its strengths and weaknesses.

\section{Challenges Facing the Justice System}

There are at least three serious challenges currently facing the legal system of Afghanistan: A) integration of state and local systems; B) resource constraints; and C) corruption.

\section{A. Integration of State and Local Judicial Systems}

Chapter 1 considered the differences between the state-sponsored formal legal system and informal local adjudicatory systems, and reviewed some advantages and disadvantages of each. You may have considered these questions simple thought exercises, but the underlying issues are very real. Many citizens of Afghanistan prefer the local systems to the state-sponsored systems for a variety of reasons. Some consider the state-sponsored justice system slow, bureaucratic, and corrupt, and some see it as an intrusion by a faraway government on their culture and way of life. Others note the local systems' focus on social harmony and reparation, and argue that these systems promote greater societal good than the "prison-focused" state system. In the eyes of many, the local systems work well when compared to the formal system.

For others, however, the local systems are not working. Despite protections offered by international law, the 2004 Constitution, Islamic law, and various provisions of the criminal statutes of Afghanistan for example, many local systems still deprive women of equal protection under the law. The systematic abuse women suffer as a result of customary law is perhaps the strongest reason to favor the formal system. 
Another argument in favor of the formal system is that as Afghanistan continues to develop, travel will become easier and people will become more mobile. With the resulting population shifts, differences between local systems will become more apparent. In such a situation, regional and/or national standardization of law and procedure will be increasingly important.

Perhaps the greatest challenge for the legal system as a whole will be addressing this dilemma in a way that satisfies the concerns of both the state and local systems. One possible solution discussed earlier would be to adopt principles of the alternative system--mediation and collaboration--into the state system. Another possible solution is to "formalize" the local systems by explicitly recognizing them through statute, reforming their treatment of women, and giving them authority to deal with certain issues.

Many other methods of integrating the two systems have been proposed, but for all the proposals, little progress has been made towards integration. The continuing existence of two separate justice systems poses an ongoing problem, and one unlikely to be resolved without a serious commitment from all stakeholders, that is, individuals who want to have access to dispute settlement mechanisms. Overall, the divisions between the different systems create serious problems for the judicial system in Afghanistan.

\section{B. Resource Constraints}

A second major issue facing the justice system is the lack of adequate resources. While many parts of the government are operating under similar resource constraints, the problem is particularly acute when it directly affects issues of liberty and justice. For example, only a small fraction of the estimated 8,000 to 10,000 suspects arrested every year receive the assistance of counsel guaranteed them by the current Constitution. Further, while there are over 2,000 prosecutors in Afghanistan, as of May 2007 there were only 250 lawyers registered with the Attorney Registrars Office and licensed to practice in court.

The lack of resources extends beyond the shortage of attorneys. The judiciary is in dire need of access to legal research materials, laws, and published opinions. Without access to up-todate written materials, judges are forced to rely on old laws (if available) or simply on their own good judgment. Real legal reform will be nearly impossible if those entrusted with implementing the new system are not aware of the laws.

Currently, international aid organizations play a major role in judicial reform. International agencies have trained many judges and donors have helped build courthouses throughout the country. And while the continued support of the international community is essential, the legal and academic communities of Afghanistan also must take the leading role in reform. Raising public awareness and understanding of the Constitution and laws will help reforms take hold and put pressure on the judiciary to take their new legal obligations seriously. 


\section{Corruption}

Corruption in the legal system in Afghanistan exists at all levels and in all areas. While the entire legal system is perhaps not so corrupt as to be unfair, no one can deny that the police, judiciary, prosecution, and prison systems have all harbored corruption.

The vast majority of the corruption seen in Afghanistan is in the form of bribes. There have been cases where an individual has been put in prison for doing a crime and his family was able to free him by paying one of the prison guards a bribe. Further, bribes also have had a significant effect on policing, reporting of crimes, and criminal prosecution. The criminal justice system is likely the most affected by corruption, mostly because it has the largest number of people in its bureaucracy making supervision is difficult. However, the civil justice system has also known corruption. Additional types of corruption include the unequal application of laws to injure certain people and certain groups, as well as the overcharging of fees by lawyers.

There are some people who argue corruption is not bad, that paying a bribe is just part of the cost of participating in the legal system. However, not only are bribes illegal, but they also have a continuous negative effect on the legal system. The practical effect of a bribe is to raise the cost of access to the legal system. This means it becomes more expensive to bring a claim in civil court or more importantly, to even defend against a criminal accusation. Some individuals can pay higher prices and therefore their participation in the legal system is unaffected. Yet for individuals who cannot pay that extra price, the legal system and the protection of their rights becomes too expensive and they cannot afford it. Additionally, when bribes are only imposed in some cases, it makes the application of the law inconsistent and discriminatory.

\section{Challenges to the Legal System in a Historical Context}

The current challenges are not unique to this era. In a report by an international team visiting during the mid-1960s, right after the enactment of the 1964 Constitution, the team outlined the challenges in the judiciary of Afghanistan:

The central problem: manpower. The main obstacle in the way of reaching the goals spelled out in the constitution is the lack of enough skilled personnel to do the work that needs to be done. The nation is fortunate in having a small group of dedicated and highly competent men in the Ministry of Justice, but otherwise is extremely short of the type of skills needed.

Another important problem: physical facilities. Afghanistan's efforts to improve its judicial system are seriously impeded by a lack of adequate physical facilities. Particularly, Afghanistan is in dire need of: a better communication system for the police, scientific laboratories, publishing facilities for legislation and legal decisions, and additional books (Schaffer and Karlen 1965). 


\section{Discussion Questions}

1. Can you think of specific examples of local and state-sponsored justice systems working together? What was the result? Do you think cooperation is possible in other areas? If you were in charge of integrating the systems, how would you get local leaders to "buy-in" to a hybrid system?

\section{THE INSTITUTIONS OF THE LEGAL STRUCTURE OF AFGHANISTAN}

\section{Reading Focus}

Turn to your supplement and read the Bonn Agreement. As you read the following section, think about how it began the process of the reconstruction of the government and legal system in Afghanistan.

\section{A. The Constitution}

In November 2003, a constitutional Loya Jirga was convened. In its own words, the Loya Jirga was convened "as the supreme manifestation of the will of the Afghan people . . to adopt a constitution that fosters the establishment of lasting peace in Afghanistan." 502 delegates from all areas of Afghanistan came to a consensus on January 4, 2004, and the current Constitution came into force.

The Constitution enumerates a wide array of fundamental rights including the right of equality of all citizens. The Constitution may be amended by a two-thirds majority vote of the Loya Jirga. (Art. 150). However, the Constitution stipulates the provisions for individual rights may only be amended "only to improve them." (Art. 149). Individual rights will be discussed more in detail in Chapter Six.

The Constitution is meant to be a permanent guiding structure for the government of Afghanistan. Certain provisions of the Constitution may be suspended - but not amendedduring a "state of emergency" declared by the President and endorsed by the National Assembly, but this is intended to be a rare occurrence. (Art. 143-148).

\section{Constitution of Afghanistan}

\section{Preamble}

We the people of Afghanistan:

Believing firmly in Almighty God, relying on His divine will and adhering to the Holy religion of Islam; 
Realizing the previous injustices, miseries and innumerable disasters which have befallen our country;

Appreciating the sacrifices, historical struggles, jihad and just resistance of all the peoples of Afghanistan, admiring the supreme position of the martyr's of the country's freedom;

Comprehending that a united, indivisible Afghanistan belongs to all its tribes and peoples;

Observing the United Nations Charter as well as the Universal Declaration of Human Rights;

And in order to:

Strengthen national unity, safeguard independence, national sovereignty and territorial integrity of the country;

Establish an order based on the peoples' will and democracy;

Form a civil society void of oppression, atrocity, discrimination as well as violence, based on rule of law, social justice, protecting integrity and human rights, and attaining peoples' freedoms and fundamental rights;

Strengthen political, social, economic as well as defense institutions;

Attain a prosperous life and sound living environment for all inhabitants of this land;

And, eventually, regain Afghanistan's appropriate place in the international family;

Have, herein, approved this constitution in accordance with the historical, cultural and social realities as well as requirements of time through our elected representatives in the Loya Jirga, dated January 3, 2004, held in the city of Kabul

\section{B. Statutory Law}

Statutes must be passed by both houses of the National Assembly and signed by the President, after which it becomes controlling law. Statutory law, however, is subordinate to the Constitution and can be changed by a subsequent National Assembly and President. The structure of the National Assembly is discussed below in the section on the legislature.

\section{Constitution of Afghanistan}

\section{Article 94}

Law shall be what both houses of the National Assembly approve and the President endorses, unless this Constitution states otherwise. 
In case the President rejects what the National Assembly has approved, the President shall send it back, within 15 days from the date it was presented, to the Wolesi Jirga mentioning the reasons for rejection, and, with expiration of the period or if the Wolesi Jirga re-approves it with two-thirds of all the votes, the draft shall be considered endorsed and enforceable.

Any law passed by the National Assembly after its election in October 2005 is the statutory law of Afghanistan until it is repealed by another vote of the National Assembly or until the time for which it was enacted expires. Afghanistan does retain other statutory law, the continued validity of which was settled by the Bonn agreement until it is superseded by the legislature by the passage of another law.

For example, during the period of 1965 to 1973, as discussed in Chapter 1, extensive criminal and civil codes were enacted by the legislative branch. Because these laws were never formally repealed, they may still be viable law under the Bonn Agreement now that Afghanistan has returned to a constitutional structure. This book will return to this phenomenon, especially in Chapter 4 on the Criminal Law of Afghanistan, but it is important that you be aware of it at the outset. The Bonn Agreement, which you learned about in Chapter 1, said that all prior law remains valid unless it is inconsistent with the Agreement or international legal obligations. Edicts from the Taliban era were certainly not consistent with the agreement or international law, but it is still unclear whether laws from the communist and civil war periods remain in effect. Whether laws such as 1976 Penal Code are enforceable also remains an open question since the National Assembly under the current Constitution has never formally adopted the measure. As the National Assembly begins to pass more laws updating past law, the status of the laws of former governments may become clearer.

\section{What is a Civil Law System?}

Afghanistan is a civil law country. Civil law is a legal system inspired by Romans, the primary feature of which is that laws are written into a collection, codified, and not determined by judges. The guiding principle of a civil law system is to provide citizens with an accessible and written collection of the laws which apply to them and which judges must follow. It is the most prevalent and oldest surviving legal system in the world.

Keeping this in mind, suppose you are a judge and have a case concerning a person's horse that was scared and trampled a spectator at a parade. The spectator is in court asking for money from the horse owner for the injuries she suffered from the trampling.

In order to determine whether and if so how much money the woman will receive, you would have to look to the civil code to see what it says. If the civil code says that someone injured by an uncontrolled animal shall receive the amount of their physical injury, how does this apply to the case? You will have to use this provision of the civil code to determine if the animal was in fact uncontrolled or if it was a mistake that was not caused by the owner. This situation is an example of the use of the civil law, general written provisions, to apply to a specific case. It requires judges and lawyers to think analytically about how these general statements of the law apply. 


\section{Discussion Question}

Imagine you are a prosecutor whose job it is to charge people who break the law with a crime. The police bring a suspect to you who they say they witnessed stealing cloth. You have enough evidence to charge the man with theft, but you are unsure how to do it. In your office, you have a copy of the 1976 criminal code and you know that the legislature hasn't written a new criminal code. Can you charge the man with theft, or must you let him go? Keep in mind both Article 27 of the Constitution: "No deed shall be considered a crime unless ruled by a law promulgated prior to commitment of the offense" and the Bonn Agreement.

\section{The Executive Branch}

The executive branch of a government generally concerns the authority to enforce the law and to ensure the laws are carried out as intended. The executive branch of the government of Afghanistan is made up of the President, the ministries, and the non-judicial institutions of the criminal justice system.

\section{The President}

The President of Afghanistan, as dictated by the Constitution, is the head of state, chair of the Ministries (or Cabinet) and commander in chief of armed forces. Aided by a first and second vice president, the president is Afghanistan's representative to the international community, and is responsible for appointing the ministers, the Attorney General, the Justices of the Supreme Court, the Head of the Central Bank, and various other posts with the approval of the Wolesi Jirga. The President may also suggest policies and reforms through the act of presidential decree, which become law upon approval by the National Assembly.

The President takes his oath upon the Constitution and therefore, obligated to obey the Constitution. Perhaps even more interestingly, the President has the responsibility to supervise the implementation of the Constitution, suggesting he or she is in charge of making sure the Constitution is properly implemented.

\section{Constitution of Afghanistan}

\section{Article 64}

The President shall have the following authorities and duties:

Supervise the implementation of the Constitution;

Determine the fundamental lines of the policy of the country with the approval of the National Assembly;

Being the Commander in Chief of the armed forces of Afghanistan; 
Declare war and peace with the endorsement of the National Assembly;

Take necessary decisions to defend territorial integrity and preserve independence;

Dispatch armed forces units outside of Afghanistan with the endorsement of the National Assembly;

Convene the Loya Jirga except in the situation prescribed in Article 69 of this Constitution;

Proclaim as well as terminate the state of emergency with the endorsement of the National Assembly;

Inaugurate the sessions of National Assembly and Loya Jirga;

Accept the resignations of vice-presidents of the Republic;

Appoint the Ministers, the Attorney General, the Head of the Central Bank, the National Security Director as well as the Head of the Red Crescent with the endorsement of the Wolesi Jirga, and their dismissal and acceptance of resignation;

Appoint the Justice of the Supreme Court as well as justices of the Supreme Court with the endorsement of the Wolesi Jirga;

Appointing, retiring and accepting the resignation and dismissal of judges, officers of the armed forces, police, national security as well as high-ranking officials according to the provisions of law;

Appoint heads of political representatives of Afghanistan to foreign states as well as international organizations;

Accept credentials of foreign political representatives in Afghanistan;

Endorse laws as well as judicial decrees;

Issue credential letter for conclusion of international treaties in accordance with the provisions of the law;

Reduce and pardon penalties in accordance with the provisions of the law;

Bestow medals, insignias as well as honorary titles in accordance with the provisions of the law;

Establish commissions to improve the administration of the country in accordance with the provisions of the law;

Perform other authorities and duties enshrined in this Constitution. 


\section{The Ministries}

According to the Constitution, the President many nominate ministers to lead the ministries under the President's chairmanship from among the members of the National Assembly and with confirmation by Wolesi Jirga. Together, the President and the various Ministries form what the Constitution calls "The Government." Under the Constitution, the Government is charged "executing" the provisions of the Constitution. The Ministry of Justice, Ministry of Finance, the Ministry of Water, and the Ministry of Education are among Afghanistan's twenty five ministries. The ministries are charged with carrying out laws passed by the National Assembly, and drafting regulations.

Ministries are important because they structure much of the day-to-day lives of the people of Afghanistan by setting policy in a certain area. An important ministry for you to be aware of in your legal studies is the Ministry of Justice (MOJ). The MOJ is primarily responsible for upholding the rule of law. It is also responsible for much of the government's judicial affairs and has a broad mandate that includes drafting, publishing, and distributing legislative documents, promoting legal awareness, protecting state properties through the court system, and managing the prisons, detention centers, and juvenile rehabilitation centers throughout the country.

The MOJ is divided into ten departments as follows: 1) Administration (Umomi-idari); 2) Government Cases (Qazawya-dawlat); 3) Inspections (Taftish); 4) Juvenile Justice (Markawziislah-watebe-ya-i-atfal); 5) Law Drafting and Review (Taqnin); 6) Office of the Minister (Daftar Muqam); 7) Political Parties and Social Organizations(Insijam); 8) Publications (Nasharat); 9) Prisons (Umomi-mahawbis); and 10) Rights (Hoqooq). Excluding corrections staff, as of May 2007, the MOJ had roughly 1,300 employees, with approximately 375 in Kabul.

One of the most important functions performed by the MOJ is through the Taqnin division. Specifically, the Taqnin division drafts laws to be considered and passed by the National Assembly. Before a law may be considered by the National Assembly, the Taqnin division reviews the proposed law to make sure it is in accordance with the principles of both the Constitution and the principles of Islamic law. This function is fundamental to lawmaking because it ensures the laws considered by the National Assembly have been thoroughly researched and determined to be consistent with Afghanistan's system of government.

\section{Constitution of Afghanistan}

\section{Article 76}

To implement the fundamental lines of the policy of the country and regulate its duties, the Government shall devise as well as approve regulations, which shall not be contrary to the body or spirit of any law.

\section{Discussion Question}

One of the guiding principles of a democracy is accountability. Accountability means that voters can vote representatives out of office in the next election if they do not like their performance in 
office. Presumably, voters could vote the president out of office if they do not like what the ministers do. Is this realistic? Does Government wield too much power under Article 76 to have be accountable in this way?

\section{The Institutions of the Criminal Justice System}

\section{i. The Police}

The Afghanistan National Police (ANP) is often the most visible segment of the executive branch. Citizens of Afghanistan are more likely to come across the ANP than any other executive branch officials in their daily activities. The ANP is part of the Ministry of Interior and charged by the President with enforcing the criminal laws of Afghanistan.

The 62,000-person ANP force consists of the Uniformed Police, Criminal Investigation Police, Border Police, Civil Order Police, Counterterrorism Police and Counternarcotics Police. The largest number of those are uniformed police (approximately 40,000 members) followed by Border Police (17,000 members) and Civil Order Police (5,000 members). Currently, there is roughly one police officer in Afghanistan for every 576 people. The ANP is rigorously training new recruits, however, and of the 80,000 positions authorized within the police force, as of March 2009, 96 percent of those were filled.

Geographically, the ANP is organized into eight regional commands and then into smaller provincial commands. The Constitution provides that the discovery of crimes is the duty of the police, while investigation and prosecution are left to the Attorney General's Office (Saranwal). Thus, the main duty of the ANP is to detect crime. To fulfill this duty, the police rely heavily on citizens of Afghanistan to report crime. The ANP also operates a forensic lab in Kabul, which is responsible for fingerprints, drug-testing, and crime scene analysis.

Entry-level training for the ANP is conducted at the Central Training Center in Kabul or at one of seven Regional Training Centers located in Kandahar, Herat, Gardez, Mazar-i-Sharif, Konduz, Jalalabad, and Bamyan. Recruits attend an eight-week training program covering the following areas: general police duties; weapons proficiency, first aid, human rights training, community policing, basic border police training, and the law and culture of Afghanistan. Many undergo specialized training courses in bomb disposal, fingerprinting, traffic management, unarmed combat, crime scene investigation, advanced firearms instruction, or civil order/riot control skills.

ANP officers and noncommissioned officers are trained at the National Police Academy in Kabul. The academy's three-year training program for officers graduated its first class of 251 sarans (second lieutenants) in August 2005. To date, the academy's nine-month noncommissioned officer program has trained more than 2,500 police sergeants, including more than 50 women. Training at the National Police Academy consists of police operations, tactics, traffic policing, management, and criminology. 


\section{ii. The Prosecution}

\section{Constitution of Afghanistan}

\section{Article 134}

(1) Discovery of crimes is the duty of the police and investigation and prosecution are conducted by the Attorney's Office in accordance with the provisions of the law.

(2) The Attorney's Office is part the Executive branch, and is independent in its performances.

(3) The structure, authority, and activities of the Attorney's Office are regulated by law.

(4) Discovery and investigation of crimes related to the armed forces are regulated by a special law.

The Saranwal or Attorney General's Office (AGO) houses the country's criminal prosecutors. The AGO is an independent executive agency led by an Attorney General who is appointed by the President and confirmed by the Wolesi Jirga. According the Article 134 of the Constitution, the AGO is responsible for the investigation and filing of cases against the accused in court.

There are three units of the AGO: Civil, National Security, and Military. These units are further broken down into six departments, each headed by a Deputy Attorney General, though the Division of National Security is headed by the Director of National Security. The Civil Unit is responsible for investigating and prosecuting Penal Code cases in the criminal courts, while the National Security Unit is responsible for investigating and prosecuting terrorism cases in the National Security Courts. Finally, the Military Unit is responsible for investigating and prosecuting criminal cases against police and other law enforcement officers.

As of May 2007, there were 2,247 total prosecutors in the AGO: 1,750 assigned to the Civil Unit, 169 to the National Security Unit, and 328 to the Military Unit. The AGO is headquartered in Kabul and has provincial offices throughout the country.

\section{iii. The Defense}

\section{Constitution of Afghanistan}

\section{Article 31}

(1) Every person upon arrest can seek an advocate to defend his rights or to defend his case for which he is accused under the law.

(2) The accused upon arrest has the right to be informed of the attributed accusation and to be summoned to the court within the limits determined by law.

(3) In criminal cases, the state shall appoint an advocate for a destitute. 
(4) The confidentiality of oral, written or telephonic communications between an advocate and his accused client are immune from invasion.

(5) The duties and authorities of advocates shall be regulated by law

Despite the provision in the Constitution giving every person arrested the right to a lawyer, the role of a defense attorney is largely unknown in many parts of Afghanistan. The defense bar is very small and in some areas, non-existent. For example, Afghanistan's Attorney Registrar's Office currently lists approximately 250 lawyers who are licensed to practice in court (not all attorneys have registered, however, so actual numbers could be larger). Consequently, only a small fraction of the estimated 8,000-10,000 criminal defendants arrested each year receive assistance of counsel. Instead, defendants either proceed through the criminal justice system without representation, or with the help of a friend or relative who generally has little, if any, formal legal training.

Four primary non-state legal aid providers currently supply criminal defense to those who cannot afford a lawyer: the International Legal Foundation, the Legal Aid Organization of Afghanistan, Da Qanon Gashtunkay, and Medica Mondial. These organizations have established offices in many cities in Afghanistan, but do not have adequate resources to represent all criminal defendants.

Currently, the Legal Aid Department under the MOJ is the only state-sponsored criminal defense office. Moreover, the Legal Aid Department represents very few people and lacks the resources to increase its caseload.

\section{iv. The Correctional System}

The Central Prisons Department (CPD) is by far the largest of the ten departments within the MOJ. It was transferred to the MOJ from the Ministry of Interior in 2003, and has organized its own structure separate from that of other MOJ departments.

The CPD is responsible for all detention centers and prisons throughout the nation. In contrast, the ANP are only responsible for smaller "lock-ups" in police stations, where defendants are to be held for a maximum of three days (with the exception of the police-run Kabul Detention Center, which can hold defendants for up to 15 days). Besides administering the country's prisons and detention centers, the CPD is responsible for transporting inmates to various courts for trials and hearings. The CPD has a contingent of about 3,500 officers, noncommissioned officers, and soldiers. Currently, there are approximately 10,600 inmates in CPD facilities.

The goal of the CPD is to have a detention center in each of the 357 administrative districts in Afghanistan, and a prison in each of the 34 provinces (in addition to the central prison at Pul-i-Charkhi). This goal has not yet been met, however, as currently only about 120 districts have some type of detention center. 


\section{Discussion Questions}

1. It is the duty of the police to discover crime, but in reality the police cannot fulfill this duty without the help of the ordinary citizen. What are the duties of the citizens of Afghanistan in the criminal justice system? Are these legal duties or moral duties? Is it important for citizens to have a formal role in the criminal justice system? Why?

2. Under the Constitution, prosecutors are given the power to investigate crimes and file indictments in court. This means that prosecutors have great discretion in deciding what crimes are prosecuted, and which are not. What are the advantages and disadvantages of giving prosecutors such discretion? Should there be checks on this discretion? If so, how would such checks operate?

3. Currently, there are far more prosecutors in Afghanistan than defense attorneys. Is this dangerous? Should prosecutors treat unrepresented defendants any differently than they treat defendants represented by counsel? Should courts be under any obligation to protect defendant's rights if no defense counsel is available?

\section{The Legislative Branch}

A legislature is a type of deliberative assembly with the power to pass, amend, and repeal laws. Law created by a legislature is called legislation or statutory law.

\section{Constitution of Afghanistan}

\section{Article 90}

The National Assembly shall have the following duties:

Ratification, modification or abrogation of laws or legislative decrees;

Approval of social, cultural, economic as well as technological development programs;

Approval of the state budget as well as permission to obtain or grant loans;

Creation, modification and or abrogation of administrative units;

Ratification of international treaties and agreements, or abrogation of membership of Afghanistan in them;

The National Assembly is the legislative branch of Afghanistan's government and according to the Constitution, is "the manifestation of the will of [the] people and represents the whole nation." (Art. 81). Generally, the National Assembly is charged with passing, modifying, and abrogating laws, and with approving the government budget. Moreover, statutory law must 
be accepted by both houses and signed by the President before it can enter into force. Specifically, the National Assembly is divided into two houses, the Wolesi Jirga or the House of People and the Meshrano Jirga, the House of Elders.

The Wolesi Jirga, regarded as the lower house of the National Assembly, is the chamber that bears the greater burden of law making in the country and was styled after the British House of Commons. The Wolesi Jirga has the primary responsibility for making and ratifying laws and approving the actions of the President including, but not limited to, approving various appointments to Ministries and the Supreme Court.

Consisting of 249 members who are directly elected, members come from each district and serve for five years. The Constitution, however, guarantees that at least 64 delegates be female. Kuchi nomads elect are allowed ten representatives.

\section{Constitution of Afghanistan}

\section{Article 83}

Members of the Wolesi Jirga shall be elected by the people through free, general, secret, and direct balloting.

The work period of the Wolesi Jirga shall terminate, after the disclosure of the results of the elections, on the 1st of Saratan/Changash of the 5th year and the new National Assembly shall commence work.

The elections for members of the Wolesi Jirga shall be held 30 to 60 days prior to the expiration of the term of the Wolesi Jirga.

The number of the members of the Wolesi Jirga shall be proportionate to the population of each constituency, not exceeding the maximum of 250 individuals.

Electoral constituencies as well as other related issues shall be determined by the elections law.

The Meshrano Jirga, which is regarded as the upper house of the National Assembly, generally plays a more advisory role in government, but has particular say in approving various laws and in budgetary matters.

The Meshrano Jirga consists of 102 indirectly-elected members who possess "staggered" terms of office and who are elected by different bodies. Specifically, one-third of the members are selected by the President for a term of five years. The President, however, is required to select women for half of those appointments along with two appointments from each the disabled and the Kochi. Another third are elected from provincial councils for a term of four years. Another third are elected from district councils for a term of three years. 


\section{Constitution of Afghanistan}

\section{Article 84}

Members of the Meshrano Jirga shall be elected and appointed as follows:

From amongst the members of each provincial council, one individual shall be elected by the respective council for a 4-year term;

The remaining one third of the members shall be appointed by the President, for a 5-year term, from amongst experts and experienced personalities, including two members from amongst the impaired and handicapped, as well as two from nomads.

The President shall appoint 50 percent of these individuals from amongst women. The individual selected as a member of the Meshrano Jirga shall lose membership to the related Council, and, another individual shall be appointed in accordance with the provisions of the law.

\section{The Loya Jirga}

The Loya Jirga or "Grand Assembly" is, according to the Constitution, "the highest manifestation of the people of Afghanistan." (Art. 110). Unlike the other branches of government, the Loya Jirga is not a standing body, but only acts when convened by itself or by the President. Specifically, the Loya Jirga may be convened to amend to the Constitution, and to decide matters related to "independence, national sovereignty, territorial integrity and the supreme interests of the country." It is also charged with removing the President while in office and dealing with extending a state of emergency.

The Loya Jirga is composed of all members of the National Assembly and the chairpersons of the provincial and district councils. The President, Supreme Court Justices and Ministers may participate in Loya Jirga sessions, but without the right to vote. . The Loya Jirga has very specific powers. It may amend the Constitution, make decisions on the territorial integrity and independence of the country, and prosecute the president.

\section{Constitution of Afghanistan}

\section{Article 111}

The Loya Jirga shall convene in the following situations:

To decide on issues related to independence, national sovereignty, territorial integrity as well as supreme national interests;

Amend provisions of this Constitution;

Impeach the President in accordance with the provisions of Article 69 of the Constitution. 


\section{E. The Judicial Branch}

The primary function of the judiciary is to adjudicate legal disputes.

\section{Reading Focus}

Turn to your supplement and read the Law on Organization and Jurisdiction of Courts of the Islamic Republic of Afghanistan to start this section.

\section{The Supreme Court}

According to the Constitution, the judiciary is an independent organ of the state. Specifically, the Supreme Court is the highest judicial organ in Afghanistan and charged with deciding the legal matters that come before it. Beneath the Supreme Court, are the Courts of Appeals and the Primary Courts. Specifically, upon the request of the Government or by the lower courts, the Supreme Court is charged with reviewing all statutory laws, legislative decree and international treaties and agreements for their compliance with the Constitution. (Art. 121). The explicit inclusion of judicial review was an innovation in the 2004 Constitution since it had been included in any prior constitution in Afghanistan. Despite the explicit Constitutional provision, debate remains as to the extent of the Court's power to interpret the Constitution as opposed to its ability to interpret statutory laws, which will be discussed in the Spanta case below.

The Court is composed of the Chief Justice and eight other justices. Each of the Justices is appointed by the President for a term of ten years and must gain the consent of the Wolesi Jirga.

The Supreme Court, like the other courts in Afghanistan is divided into four dewans (derived from Arabic meaning vizier or principal advisor): (1) general criminal, (2) public security, (3) civil and public rights, and (4) commercial. Each dewan is headed by a Justice who is in charge of all the cases within that subject area. (Law of the Courts, Art 18). Moreover, the Supreme Court can also propose laws related to judicial affairs in the National Assembly and disciplining judges.

\section{Constitution of Afghanistan}

\section{Article 121}

The Supreme Court upon request of the Government or the Courts can review compliance with the Constitution of laws, legislative decrees, international treaties, and international conventions, and interpret them, in accordance with the law.

Each Supreme Court decision made by the must be published in public opinion that everyone is allowed to read. This practice, however, has not always been followed. Consider the case of Sayed Pervez Kambakshwhere, an Afghan journalist. Kambakshwhere published an article criticizing a certain interpretation of the Qu'ran and was subsequently sentenced to 20 
years in prison for blasphemy. The Supreme Court did not publish its decision upholding his sentence. In fact, the reporter's brother only learned the sentence had been upheld a month after the decision.

\section{Discussion Questions}

1. What do you think are the most important qualities in a Supreme Court Justice?

2. Do you think that judges should be able to look to religion when making their decisions? In what circumstances under the Constitution can they look to religion?

\section{Primary Courts and Courts of Appeal}

\section{Constitution of Afghanistan}

\section{Article 116}

(1) The judicial branch is an independent organ of the state of the Islamic Republic of Afghanistan.

(2) The judicial branch consists of the Supreme Court, Courts of Appeal, and Primary Courts.

(3) The Supreme Court is the highest judicial organ, and heads the judiciary organ of the Islamic Republic of Afghanistan.

Before a case may reach the Supreme Court, it must be brought before the Primary Court in the district where the case originated. There are both Primary Courts with general jurisdiction, called the Central Primary Courts and Primary Courts with specialized jurisdiction, specifically: Central Provincial Primary Court, Juveniles Court, Commercial Primary Court, District Primary Court, and Family Primary Court.

While the Central Primary Court is a court of general jurisdiction, meaning that any legal case may be brought there, it is also broken down into five dewans: General Criminal, Civil, Public Rights, Public Security, and Criminal Traffic. The other specialized Primary courts mentioned above only hear cases within their specialized jurisdiction. Overall, Primary Courts see 42 percent of their cases as criminal cases, 37 percent as civil cases, 14 percent as national security cases, and 7 percent as commercial cases.

After a panel of three judges on the Primary Court (assuming three judges are available) decides the case, the losing party may appeal the decision to the Court of Appeals of the province. Some decisions of the Primary Courts, however, are final and cannot be appealed. According to Article 53 of the Law of the Courts, the following cases are considered final: (1) when both parties agree with the decision, (2) when the time for appeal has expired, (3) when the disputed property is worth 100,000 Afghanis or less, and (4) when a cash fine of 50,000 Afghanis or less is issued. 
Like the Primary Court, the Courts of Appeal are divided along subject matter (and therefore, their jurisdiction) so that an individual must appeal to the court that fits the subject of their case. There are six dewans in the Court of Appeal: General Criminal, Public Security, Civil and Family, Public Rights, Commercial, Juveniles. The Court of Appeal may affirm (agree with the Primary), reverse, and/or remand the case to the Primary Court to further consider the case in light of the Court of Appeal's legal reasoning and/or facts of the case. If the losing party in the case wishes to further appeal the decision of the Court of Appeals, they may appeal to the Supreme Court. The Supreme Court, however, will not review the facts of case, only the legal reasoning.

Article 128 of the Constitution provides that all trials are to be open to the public and transparent, with all final decisions available to the public. Article 31 of the Constitution provides that each person is entitled to a defense attorney. In addition, the Law of the Courts, Article 58 sets down several requirements for being a judge. They include: the person must be a citizen of Afghanistan for at least ten years, he should not have been convicted of any crime, he must hold a degree in law or Islamic law or religious studies center, and he or she must be 25 years of age or older.

\section{Discussion Question}

Imagine you are a businessman with a gravel pit. Your customer refuses to pay for a load of gravel you delivered to his house. Could you bring this case to court? Would you want to?

\section{Interpretation of the Constitution - The Spanta Case}

On May 10, 2007, the Wolesi Jirga, attempted a vote of censure against then Foreign Minister Rangin Dadfar Spanta. The initial effort failed by one vote, but two days later, the Wolesi Jirga succeeded in "stripping" him of his minister status. President Karzai refused to recognize the legitimacy of the Wolesi Jirga's vote arguing the lower house lacked the authority to censure a sitting Minister and that the power to remove a sitting Minister was the sole prerogative of the President.

President Karzai formally requested that the Supreme Court review the decision. On June 3, 2007, the Supreme Court, declared that second vote violated the Constitution because the Wolesi Jirga had no authority to censure sitting Ministers.

The Wolesi Jirga responded by asserting the Supreme Court lacked the authority to interpret the Constitution with respect to the actions stated above and pledged not to follow the Court's ruling. Spanta would continue serving as foreign minister for several more years.

Article 121 of the Constitution of Afghanistan explicitly gives the Supreme Court the authority to interpret the laws, treaties, and legislative decrees for their conformity with the Constitution. 
However, the Constitution is silent about the authority of the court to interpret the constitutionality of actions that are not in the form of "laws," "decrees," or "treaties."

The President argued that the ability to interpret the Constitution was itself necessary to effectuate the overarching function of a judiciary. Members of the Wolesi Jirga who challenged the President's contention regarding the Supreme Court argue that the specific omission of any mention of the ability to interpret the Constitution in Article 121 proves their argument that if it was intended for the Supreme Court to interpret beyond the specific provisions of Article 121, it would have been included in the Constitution.

A closely related issue asks whether the Supreme Court exceeded its authority under Article 121 under the Constitution. In this case, remember that the vote in question was a vote of censure. Does that mean that the vote falls under the bounds of Article 121? There was no "law" being considered, only a legislative act. Thus, did the Supreme Court exceed its jurisdiction?

Interestingly, the National Assembly responded to the Court's decision by passing, over the veto of President Karzai, a statue creating the Independent Commission for the "Supervision of the Implementation of the Constitution" which is mentioned in Article 157 of the Constitution. In September 2008, the National Assembly passed legislation giving the power to "interpret" the Constitution to the Commission. The Supreme Court was asked to review the constitutionality of the act and declared it in violation of Article 121 of the Constitution. In 2010, the Wolesi Jirga succeeded in passing legislation that established the Independent Commission. It remains unclear as to whether these commissioners will have the power to "interpret" the laws.

It also worth considering that under Article 64, the Constitution charges the President with the authority to "supervise the implementation of the Constitution" --a provision identical to the goal set forth in Article 157. Of perhaps equal importance is the fact that under Article 157, the members of the Commission shall be appointed by the President and confirmed by Wolesi Jirga.

\section{Discussion Questions}

At the time of the Spanta dispute, who do you think was correct about whether the Supreme Court can interpret the Constitution? Do you think that the new law itself is constitutional? What is the role of statutory law in this controversy? What do you think about the National Assembly's attempt to place the power to interpret the Constitution within the Commission, considering the Commission's authority appears to derived from the Executive Branch?

\section{The Regional Administration}

Afghanistan is a centralized, constitutional state under the governance of the President and the National Assembly. Almost all budgeting, administrative appointment, and lawmaking decisions are made in Kabul. However, the Constitution does provide for some de-centralization of the administration of Afghanistan to the provinces, including the responsibility for economic, social, and cultural affairs. These provinces are governed by a Provincial Council that is elected 
in open provincial election by secret ballot every four years. District Councils govern the local affairs in each district or village. They are elected by open and secret ballot every three years. Elections for the District Council have not occurred yet and are scheduled to occur in 2010 at the same time as the National Assembly elections. Similarly, cities are under municipal governance with an elected mayor as the chief executive of the city.

The Afghan National Development Strategy states that there is a problem with "excessive centralization" and "although discussion of decentralization of certain functions and assignments is at an early stage. . . over time it may be desirable to consider a degree of de-centralization and/or de-concentration of some policymaking and budget responsibilities." This suggests that in the future, the provinces may gain more governance responsibility.

\section{Discussion Question}

Is decentralization of power from the central government to the provinces a good idea? Think back to the history you studied in the beginning of Chapter One when forming your opinion.

\section{THE LEGAL PROFESSION}

This section speaks to the crucial role of lawyers in a society governed by the rule of law. The preface to this volume addressed this topic as well, but this section will look in depth at the important role served by lawyers in a system with the rule of law. This section will also introduce the skills that a lawyer must have to perform two roles: advocate and advisor. By the end of this section, you will have a better understanding of (1) oral advocacy, (2) written advocacy, and (3) ethical commitments a lawyer makes in his or her profession. Through interactive activities, you will apply the skills of a lawyer to common situations in order to practice thinking like a lawyer.

\section{Reading Focus}

As you read about the job of a lawyer, ask yourself whether you would find the job interesting and rewarding.

\section{Lawyers and the Rule of Law}

The lawyer plays a special role in a society governed by the rule of law. According to one rule of law commentator:

A well developed legal profession and legal tradition committed to upholding the law is necessary for several reasons: to develop the body of legal rules in a coherent and accessible fashion that helps achieve predictability and certainty in the law; to provide the legal services required to insure compliance with the law (in vertical and horizontal terms); to help fill the ranks of government legal 
positions (including regulators, prosecutors, and judges) with the orientation that the law must rule; and to rise to the defense of the rule of law when it is under pressure. Without a body of lawyers committed to the law and to the rule of law, there can be no rule of law, for the knowledge, activities, and orientations of lawyers as a group are the social carriers of the law - they are the group whose collective activities directly constitute the law. Building a robust legal profession and legal tradition requires a legal education system that transfers legal knowledge and inculcates legal values in those it trains, and it must attract and reproduce people who are committed to the law and to developing legal knowledge (Tamanaha 2007).

Currently, there are few registered lawyers practicing any type of law in Afghanistan, although an equal number of unregistered lawyers may exist. Lawyers who take private clients, such as criminal defendants or people with a complaint, are especially underrepresented in Afghanistan.

On the other hand, there are a significantly larger number of lawyers in the government working as prosecutors, judges, and members of the Ministry of Foreign Affairs. These government officials are important because they are the human agents who direct the state to conform with the rule of law. However, private sector lawyers are just as crucial in Afghanistan. Because of its newly functioning legislature and court system, Afghanistan has a need for many more trained and registered lawyers. In this new system, lawyers play many roles, from advisor to advocate.

In the current legal system, lawyers perform a vital role in the formal realm. Lawyers can be advisors or advocates both in and out of court. For example, many businesses find that hiring lawyers is an essential step in making agreements with suppliers or buyers. Business executives need lawyers to advise them on the contracts they are making. This is a lawyer's role as an advisor.

Lawyers also act as advocates. For example, if a business is faced with a supplier that is not fulfilling its contractual obligations, the business may seek to enforce that agreement. This is a lawyer's role as an advocate in a situation where someone needs legal help. Lawyers do this both in and outside of court.

Outside of court, lawyers can act as representatives of the company and attempt to mediate the dispute with the person who broke the contract. If a dispute must go to court, lawyers act as advocates for their client's interest before the judge. Lawyers perform these two functions in many areas of law, including criminal law, family law, business law, and civil law.

A lawyer, beyond his or her work with clients, is a representative of the legal system. Because the Constitution of Afghanistan and representative form of government are new, and some citizens may not be very knowledgeable about the new system, lawyers personify the rule of law to other citizens. In this capacity, lawyers perform the vital role of informing their communities about the legal system and the government. People often seek out lawyers as trusted members of the community who can give advice about ways to solve many different 
problems. A lawyer must be ready to assist people who do not know the complexities of the law. Beyond their formal role as representatives of clients, lawyers also educate people about the legal system that governs Afghanistan.

Another important person who performs a similar role with similar skills is a paralegal, or a community legal practitioner. A paralegal is someone who is not a full-fledged lawyer because he or she has not obtained the necessary degree but who is, nonetheless, familiar with the justice system. He or she can advise individuals on the law and can help them draft legal documents. A paralegal is especially important in areas of Afghanistan where there may be no lawyers, because paralegals can perform the same function of educating individuals about the justice system. Even if you do not decide to become a lawyer, it will still be important for you to act like a paralegal and use the skills and knowledge you learn in this class to inform those around you about the legal system and how to use it. The new Constitution and court system offer many opportunities for individuals to settle their disputes in an orderly, transparent fashion. The more people who know how to use the legal system, or know someone they can go to and ask for advice, the stronger the legal system of Afghanistan will be. Lawyers play this role, but paralegals can also play a crucial role in Afghanistan.

\section{Oral Advocacy}

One of the most recognizable and important skills in a lawyer's toolbox is oral advocacy. Oral advocacy refers to a lawyer's ability to speak on behalf of his or her client in a way that informs and persuades the listener. Oral advocacy may be required in formal proceedings before a court, or in informal representation of clients in other situations such as negotiations. A successful oral advocate will demonstrate his skill through preparation, flexibility in argument, and balanced consideration of the legal issues at hand.

To persuade, a lawyer must present a sophisticated understanding of both the facts of the case he represents and the law that applies. For example, in a case where the client sues his neighbor for killing his cow with a car, the lawyer would need to be ready to discuss the detailed facts of the death of the cow as well as the law about reckless driving. Such understanding will require meeting with the client to develop insight into the origins of the problem.

Learning the facts in detail will also help the lawyer identify the legal issues involved in the case. Proper preparation will also require a lawyer to anticipate arguments that the other side might make. In the example above, the neighbor might argue that the client let his cow wander into the road and, thus, it is really the client who is to blame. A thoroughly prepared lawyer will know how to refute this argument-using a combination of facts and law-in order to advocate for a favorable outcome.

Oral advocacy should not be mistaken for mere argument, as oral advocacy frequently requires the lawyer to recognize not only his own client's goals, but also those of the opposing party as well. A lawyer may find success in negotiating with the other side to reach a solution that is acceptable to all and keeps them out of court. This is very important in Afghanistan where a client may prefer a non-court process, such as appealing to a provincial council for mediation. 
In many cases, focusing too narrowly on a single solution may ultimately discourage a resolution of the dispute and ultimately work against the client's interests.

Overall, a lawyer's main tool is his or her ability to convey her argument clearly and concisely. This ability will win her the respect of colleagues and judges before whom she presents.

\section{Written Advocacy}

The second important tool that a lawyer uses to advocate for his client is the ability to write clearly and persuasively. Similar to oral advocacy, the ability to convey in writing exactly what the client is seeking can help to resolve a case quickly and out of court. This is somewhat less important in Afghanistan as most non-court meetings will be face to face, but it is an important skill when court submissions are required. As discussed before, Afghanistan is a civil law system that relies mostly on written submissions for cases. A lawyer will have to speak in court, but his writing skills are important because the outcome of the case is usually determined by the written submissions.

Even before a legal dispute occurs, a lawyer who consults for a client, such as in the writing of a contract, must be clear and correct. Being thorough and prepared at the beginning of a legal relationship can help to ensure that no problems occur in the future. Once a problem has occurred, however, writing becomes just as important as oral advocacy. A lawyer who can write clearly, can represent her client more efficiently, as professional writing can help to resolve disputes on the front end.

\section{Lawyer's Ethics}

The final, and most important, tool on which a lawyer must rely is ethics. Ethics are the moral constraints that bind lawyers.

For example, lawyers generally should not represent clients with conflicting interests. This means that a lawyer should not represent both the injured party and the person who caused the injury. The reason for this is a lawyer, in agreeing to represent a client, becomes the client's advocate. If a lawyer were to represent a second client with a conflicting interest, even if it were in a different case, he would likely find it more difficult to argue for the first client without reservation. A conflicting interest may also arise if the lawyer has a financial interest in the case. For example, a lawyer should not represent the owner of a lapis lazuli mine in a business deal if he also owns a lapis lazuli mine and would personally benefit if that owner went out of business.

The ethics surrounding conflicts of interest are merely one consideration of many that structure a lawyer's practice. As referred to before, a lawyer is more than an advocate in a particular case. Even more importantly, she is an emissary of the judicial system as a whole who must abide by the highest standards of professionalism. Lawyers are tasked with maintaining the reputation of the judicial system through their actions. When citizens see lawyers, they automatically think of the professionalism and trustworthiness of the judicial system as a whole. Therefore, lawyers must maintain the highest standards of ethics. 
The content of these standards of ethics are somewhat dependent on the community in which a lawyer operates. However, some general principles always apply.

First, a lawyer must advocate for his client without conflict of interest. A conflict of interest can result from the situation described above with two different clients, or it could occur if the lawyer has a personal interest in the outcome of the situation. A lawyer should only accept cases that do not lead to such a conflict.

Second, a lawyer's paramount objective should always be the interests of his client. This means that a lawyer should always think about what is best for the client rather than only seeing one possible solution to a situation. This, as mentioned above, can mean that a lawyer should go through an alternative solution to a problem rather than taking the case to court.

Third, although he or she is an advocate for her client, a lawyer must not advocate for them in an illegal way. This means that a lawyer should never lie nor cover up for her client's wrongdoing.

Finally, a lawyer must be open to aiding any client who seeks her help without reservation because of age, status, or gender.

\section{Discussion Question}

A client comes to you and asks for your help. It seems he promised to buy a used car from someone, signed an agreement that he would be back with the money the next day, and then broke his promise and bought a different car instead. Now the car owner wants the money that was promised. As the client tells you the details of the situation, you realize that he was supposed to buy your uncle's car. Should you agree to represent him?

\section{CONCLUSION}

This chapter provided a general introduction to the current laws of Afghanistan. The rest of this text covers five legal topics that are the most important under the new constitutional system: civil procedure, property law, commercial law, criminal law, and individual rights. As you now turn to the more specific areas of the law of Afghanistan, keep in mind Afghanistan's legal history, current structure, and the role of lawyers. 


\section{Sources Consulted}

1923 Constitution of Afghanistan. http://www.afghanistantranslation.com.

1964 Constitution of Afghanistan. Kabul: Franklin Book Programs.

1977 Constitution of the Republican State of Afghanistan.

2004 Constitution of Afghanistan. http://www.afghanistantranslation.com.

Afghanistan Justice Sector Support Program. 2007. "Afghanistan's Criminal Justice System.

Center for Policy and Human Development. 2007. "Afghanistan Human Development Report."

Fukuyama, Francis. 2004. State Building. New York: Cornell University Press.

Grazda, Edward. 2000. Afghanistan Diary 1992-2000. New York: Powerhouse Books.

Grover, Verinder Ed. 2000. Afghanistan Government and Politics. New Delhi: Deep \& Deep Publications.

Jensen, Erik . "Justice in the Rule of Law." 2008. In Building States to Build Peace, edited by Charles Call. New York: Lynne Reinner.

Kamali, Mohammad Hashim. 1985. Law in Afghanistan. Leiden: E.J. Brill.

Laber, Jeri \& Barnett Rubin. 1985. Tears, Blood and Cries: Human Rights in Afghanistan Since the Invasion. New York: U.S. Helsinki Watch Committee.

Main Principles of the Government of Afghanistan. 1931. http://www. afghanistantranslation.com.

Marsden, Peter. 1998. The Taliban. Oxford University Press: Bangalore.

Order No. 4913 of the President of the Islamic Transitional State of Afghanistan, Rules of Procedure for the Constitutional Loya Jirga, November 2003

Ramage, Douglas E. 2007. "A Reformed Indonesia." Australian Financial Review.

Rasanayagam, Angelo. 2005. Afghanistan: A Modern History. London: I.B. Tauris.

Rashid, Ahmed. 2002. Taliban: Islam, Oil and the New Great Game in Central Asia. London: I. B. Tauris \& Company.

Rotberg, Robert Ed. 2007. Building a New Afghanistan. Washington, DC: Brookings Institution Press.

Salim, Ahmad. 2006. Loya Jirga: The Afghan Grand Assembly. Lahore: Sang-E-Meel Publications.

Sufi, Juma Khan. 2005. Afghanistan: A Chronological Fact Sheet 1600-2004. Khost: Independent Cultural Society of Khost.

Tamanaha, Brian. 2007. "A Concise Guide to the Rule of Law." St. John's University School of Law: Legal Research Paper Series. http://ssrn.com/abstract=1012051. 


\section{CHAPTER 3: CIVIL PROCEDURE}

\section{INTRODUCTION}

\section{Reading Focus}

What is the role of civil procedure in a civil law system? Is it important to have a written set of rules and procedures to regulate litigation? Should these rules be flexible or rigid? How can civil procedure contribute to or detract from the pursuit of justice through the courts? As you learn the rules of civil procedure, think about how civil procedure can and should contribute to a just legal system.

As you continue to learn about the Code of Civil Procedure, think about which articles are clear and which ones are ambiguous. What might explain the differences in the level of clarity between different articles? Is clarity always preferable? If you were redrafting the Code of Civil Procedure, what would you change?

\section{Goals of the Chapter}

The goal of this Chapter is to help students learn to think critically about civil procedure. This Chapter also serves as a primer to the most important rules set forth in the Afghan Code of Civil Procedure. Although this Chapter addresses the core values and principles underlying Afghan civil procedure, it is by no means comprehensive and should not be used as a substitute for a close reading of the Code of Civil Procedure; this Chapter is not a practitioner's guide. Rather, students and practitioners should also consult the Code and other relevant material to determine what procedures are required.

You should also be aware that civil procedure, as envisioned by the Code of Civil Procedure, may differ in significant respects from the procedures used in practice. Section $X$ of this Chapter reviews some of the differences between the Code and actual practice.

\section{What is civil procedure?}

When two parties, whether individuals or companies, have a disagreement, they may ask the courts to settle their dispute. But if the courts are disorganized, the legal process may prove to be frustratingly slow and ineffective. Civil procedure-the rules that regulate the process of litigation-plays an important role in ensuring that the courts operate smoothly and that all parties before the court can receive a fair hearing.

But procedure can also be confusing and too formal. To what degree do procedural rules help courts run smoothly in Afghanistan, and to what degree to they unnecessarily impede the ability of individuals, companies, and even governments to settle disputes? 


\section{Key Concepts and Definitions}

\section{What is litigation?}

This chapter focuses on the rules of litigation. But what is litigation? A controversy that is brought before a court of law, also known as a "lawsuit" or a "case," is commonly referred to as "litigation." The parties to litigation can be individuals, companies, or even the government. For example, if the government takes a private citizen's land without paying just compensation as required under Afghan law, a private citizen can initiate a lawsuit to ask a judge to settle the matter. Just as custom and tradition govern shuras and jirgas, litigation is regulated by a set of rules, known as civil procedure, which this chapter addresses in depth.

\section{What is a civil law system?}

Afghanistan is a civil law country. But what does this mean? Civil law is the predominate type of legal system in the world. In a civil law system, the legislative branch writes long legal codes. In Afghanistan, the legislature has approved many codes, including the Civil Code, the Criminal Code, and the Civil Procedure Code. Judges then use these codes to decide cases.

As the "Key Concepts" box (above) explains, in addition to customary law and Islamic law, which is based on Islamic principles of jurisprudence, there are two principal types of legal systems in the world: common law and civil law. Though similar in many respects, each system approaches litigation and civil procedure slightly differently.

Common law systems, like those in the United States and Great Britain, are founded in part on what is called "judge made law." Although judges cannot ignore laws duly enacted by the legislature, judges base their decisions on precedent-in other words, judges rely on past judge-made decisions to decide the cases before them. By contrast, civil law systems, like those in France, Germany, and Afghanistan, emphasize the "uniform implementation of centrally devised rules" (Kagan 2006:57). Civil law systems derive law from codes of law, which establish the central principles that guide legal decision-making. In the context of civil procedure, however, there is substantial similarity between common law and civil law systems.

Another difference between common law and civil law systems is the role of the judge. American courts, for example, operate through what is known as the "adversarial system." Under an adversarial system the truth is intended to emerge through a contest between the opposing parties. The judge decides the case but does not take an active role in producing evidence. In other words, the parties themselves (primarily through their lawyers) are responsible for asserting legal claims, searching for controlling legal precedent, and gathering and submitting evidence. Judges in civil law systems tend to be more active than their counterparts in common law systems. Unlike the common law "adversarial system," some civil law countries rely on the "inquisitorial system," in which the judge has substantial authority to investigate a case. In Afghanistan, the judge has the "authority ... to demand explanations from the plaintiff, the defendant and other persons involved" (Article 52). Afghanistan has adopted a blend between the inquisitorial and adversarial systems. 


\section{The courts compared to other dispute resolution mechanisms}

In any system, litigation can be an expensive and time-consuming way to settle disputes. The expense of litigation is just one of many reasons parties might prefer to settle their disputes without resorting to the courts. The simplest and least expensive way to settle a dispute is for the two parties to work out a solution between themselves. But this cooperative approach is not always possible. Parties might also turn to informal mechanisms, such as shuras and jirgas.

The problems of litigation notwithstanding, when other forms of dispute resolution are undesirable or fail to work, litigation may be unavoidable. The rules that govern litigation may not be complicated, but they are important if the legal system is to function efficiently and fairly.

\section{Discussion Questions}

1. What concerns might motivate an individual to turn to a shura or jirga rather than to the courts? If you had a property dispute, where would you turn first?

2. Would your decision change if your dispute had to do with family law rather than property? What if your dispute were with a foreigner?

\section{BACKGROUND: CODE OF CIVIL PROCEDURE}

\section{Reading Focus}

The Government of Afghanistan may amend the Code of Civil Procedure in the coming years. Which provisions of the Code are the most important? Which ones should be amended or deleted altogether? Is it sensible to have a Code of Civil Procedure at all?

Courts of law in Afghanistan, as in other civil law systems, operate according to a set of rules and regulations that are set forth in a code. In Afghanistan, the 1990 Code of Civil Procedure provides an extensive set of formal rules that must be followed throughout the course of litigation. (Like most countries, Afghanistan has adopted separate rules and procedures to govern the criminal and civil judicial systems.) This Code, though drafted long before the current Constitution, remains in effect today. It governs all phases of the legal process, from how to bring a case to court and how to file court documents, to whether the court has the authority to consider a particular case, to the procedure for filing an appeal.

\section{Goals of Civil Procedure}

Article 2 of the Code states the "principal objectives" of civil procedure in Afghanistan. Note the Code's first stated goal is to protect the equality of the rights of all citizens of Afghanistan. Although this Chapter addresses civil procedure, it is also about substantive rights. In other words, although you will learn about the rules that govern the various phases of 
litigation-such as when, how, and where to file a lawsuit-the rules you learn can have a significant impact on the outcome of a case and the rights of both citizens and foreign nationals.

Read Article 2 and think about the connection between civil procedure and substantive rights.

\section{Civil Procedure Code}

\section{Article 2}

The principal objectives of this Code are as follows:

1. Observing the equality of the rights of citizens and implementation of the provisions of the laws of the Republic of Afghanistan in civil cases.

2. Management of the due process in judicial proceedings.

3. Determining the limits of rights and duties of the parties to the claim, witnesses and experts.

4. Management of the manner of giving testimony and evaluation of the legal documents, absolute evidence, circumstantial evidence and grounds for judgment.

5. Management of affairs related to appeal, final appeal and review of the decisions and final rulings of the courts.

6. Expediting the proceedings in civil actions.

\section{Discussion Questions}

1. How can civil procedure affect substantive rights?

2. Can judges influence the outcome of a case by misapplying the Code? If so, how?

In many ways, civil procedure is a substantive doctrine. First, the Code applies to all parties; as such, the Code enshrines two core values: equality and fairness. Procedure also impacts substantive rights by determining how well the courts function. When lawyers and judges fail to follow proper procedures, litigation may progress slowly, resulting in a backlog of cases. When that happens, courts cannot resolve cases in a timely fashion and the rights of the parties before the court cannot be vindicated. In addition, as you will learn, if the parties before the court do not follow proper procedures, judges can decide to dismiss the case-a result that directly impacts the rights of the parties before the court.

\section{Key Concepts and Definitions}

\section{What is "due process"?}

Due process is a course of legal proceedings according to rules and principles that have been established for the enforcement and protection of private rights. Due process contemplates an exercise of the powers of government as the law permits and sanctions, under recognized safeguards for the protection of individual rights. In the context of litigation, this means ensuring that the parties before the case are allowed to exercise their rights under the law. 


\section{FIRST STEPS IN A LAWSUIT}

\section{Key Concepts and Definitions}

Plaintiff: The party who is asking the court for relief. The plaintiff can be an individual, a group of individuals, a company, or a government.

Defendant: The party against whom the claim is filed. Like the plaintiff, the defendant can be an individual, a group of individuals, a company, or a government.

\section{A. Initiating a Claim: Articles 12-17}

When two parties have a dispute, they might first try to settle the disagreement between themselves, without involving the courts. But if they fail to reach a settlement themselves, and if they decide not to use traditional institutions like shuras or jirgas, they may decide to go to the courts. What are the first steps required to initiate a lawsuit? How do the parties inform the court that they would like it to settle their dispute?

The first step is for the plaintiff to file an official request letter. The request letter can be submitted either directly to the Primary Court or through the legal bureau. Per Article 13.1, the plaintiff's legal request must contain basic information about the parties to the case, including the plaintiff's name, the name of the plaintiff's father, and the plaintiff's place of residence, occupation, and national identification number.

The request letter must also contain background information about the claim, including a "summary of the purpose of the claim" (Article 13.2). If the claim pertains to moveable property, the request letter must contain a declaration of "the nature, type and price of the subject of the claim" (Article 13.3). If the claim regards a piece of land, as is often the case in Afghan courts, the request letter must contain information about the location and size of the land (Article13.3).

\section{Reading Focus}

Read Article 13 and consider why the Code requires plaintiffs to include the elements that it does. 


\begin{tabular}{|l}
\hline Civil Procedure Code \\
Article $\mathbf{1 3}$ \\
A legal request letter contains the following matters: \\
1. Names, father's name, place, permanent and current residences, occupation, national \\
identification number of the plaintiff and the defendant. \\
2. Determination of the extent of the subject matter of the claim and a summary of the \\
purpose of the claim. \\
3. Declaration of the nature, type, and price of the subject matter of the claim, in case it is \\
moveable. If the subject matter of the claim is a piece of land, a mention of its location, \\
type, and area is also necessary. \\
4. Signature or fingerprint of the requesting party. If the requesting party is a proxy, \\
executor or curator, a mention of the number and date of power of attorney document, \\
executorship and custodianship with their full identification is necessary. \\
5. Date of the establishment of the right and the date of the presentation of the request.
\end{tabular}

After the request letter has been filed, the court then informs the defendant he has been sued. Once the defendant has received notice of the claim against him, he must decide whether to contest the case or to admit wrongdoing. If the defendant denies the truthfulness of the claim and refuses to grant the plaintiff the requested relief, the case proceeds to the next phase.

\section{B. Grounds for Dismissal}

In the next phase of litigation, the defendant can make "preliminary objections," which are challenges to the court's competence to hear the case or to the propriety of the claim. If the defendant succeeds in making a preliminary objection, the case is either dismissed or transferred to another court.

\section{Reading Focus}

Read Article 21, which establishes the eight bases for a preliminary objection. The following pages address each type of objection, in turn.

\section{Civil Procedure Code}

\section{Article 21}

Preliminary objections are as follows:

(1) Lack of jurisdiction by the court to hear the case.

(2) Lack of legal capacity on the part of the plaintiff and the defendant.

(3) Inapplicability of the claim contained in the pleading to the defendant. 
(4) Issuance of a prior legal ruling related to the issue at dispute between the requesting party and the party against whom the request is made.

(5) Absence of documented proof of the possession of the immovable subject matter of the claim.

(6) Relation of the case with a claim that is under proceedings in another court.

(7) The case contained in the request being heard in another court.

(8) The case being subject to the limitation period.

\section{i. Jurisdiction: Article 21.2}

\section{What is jurisdiction?}

To decide a case, the court must have the power, right, or authority to interpret and apply the law. In other words, the court must have jurisdiction (Article 21.1). Whether the court has jurisdiction is a threshold question, meaning that if the court does not have jurisdiction, the court will dismiss the claim and the plaintiff must file it in another court. A court without jurisdiction is powerless to decide the case.

One of the most fundamental questions of law is whether a given court has jurisdiction to preside over a given case. The term jurisdiction is really synonymous with the word "power." Any court possesses jurisdiction over matters only to the extent granted to it by the Constitution, or some statutory law. The question of whether a given court has the power to determine a jurisdictional question is itself a jurisdictional question. Such a legal question is referred to as "jurisdiction to determine jurisdiction."

Courts may also have jurisdiction that is exclusive, or concurrent (shared). Where a court has exclusive jurisdiction over a territory or a subject matter, it is the only court that is authorized to address that matter. Where a court has concurrent or shared jurisdiction, more than one court can adjudicate the matter. Where a concurrent jurisdiction exists in a civil case (two or more courts have jurisdiction), a party may attempt to engage in "forum shopping," which simply means bringing the case in the court that it thinks is most likely to rule in its favor.

\section{How to determine whether a particular court has jurisdiction}

As you remember, there are three basic types of courts in Afghanistan: the Primary Court (also known as the trial court, district court or the lower court), the Court of Appeals, and the Supreme Court.

All claims begin at the Primary Court level, and it is at the Primary Court that the defendant can make preliminary objections and ask the court to dismiss for lack of jurisdiction. By default, "civil claims at the trial stage shall be decided by the city, municipal, district or subdistrict courts" (Art. 79). However, because there are many city, municipal, district and subdistrict courts in Afghanistan, Article 79 alone does not tell us when a court has jurisdiction. The question, then, is which city, district or sub-district court should hear a particular case. 


\section{General civil claims}

Article 81 provides civil claims should be "resolved in the defendant's place of residence." If the defendant is a married woman, then the "hearing of the case shall be within the jurisdiction of the court located in the place of residence of her husband" (Art. 82). Jurisdiction in the case of a defendant who is an unmarried woman is in the place of her father's residence or close relatives (Art. 83).

\section{Special cases: Articles 84-92}

Other articles provide special jurisdictional rules for individuals who are mentally incompetent (Article 84), missing persons (Article 85), members of the armed forces and the government (Article 86), nomads (Article 87), and others. In addition, there are special procedures for certain types of substantive cases, such as contracts made by traders (Article 90) and bequests (Article 92).

\section{Jurisdiction over foreign citizens: Article 96}

The Code also provides special rules for foreign citizens. Foreign citizens who maintain a place of residence in Afghanistan are subject to the jurisdiction of Afghanistan's courts, just as an Afghan citizen would be. Article 96 governs jurisdiction for foreign citizens who do not have a place of residence in Afghanistan.

\section{Civil Procedure Code}

\section{Article 96}

In a claim related to a foreign citizen that does not have a place of residence in Afghanistan, the courts of the Republic of Afghanistan shall have jurisdiction to hear such a claim in the following situations:

1. In case the foreigner has a residence of choice in the Republic of Afghanistan.

2. In case the subject of a contract, or the place of its implementation is the Republic of Afghanistan.

3. In case the claim related to a demand for division/assignment of bequeathed property has commenced in the Republic of Afghanistan.

4. In case the whole or part of the bequeathed properties is in the Republic of Afghanistan.

\section{How to challenge jurisdiction}

Under Article 88, if either party disputes the court's jurisdiction, that party must file an objection with the court before the first hearing begins. If the party does not object to the court's jurisdiction before the first hearing, he waives his right to make an objection and the case proceeds as if jurisdiction has been accepted. 


\section{Discussion Questions}

1. Is Article 88 the last word on the matter of jurisdiction? If jurisdiction is so important, can, and should, a party be able to challenge jurisdiction later in the process if they fail to do so at the outset?

2. Why does the Code require the parties to make an objection to the court's jurisdiction before the first hearing? Can you think of any adverse consequences that would result if the parties were allowed to object to the court's jurisdiction after the first hearing?

3. Could you have confidence bringing a case to the courts if you knew that the case might be dismissed after months or even years of litigation because of a challenge to the court's jurisdiction?

\section{ii. Lack of legal capacity: Article $\mathbf{2 1 . 2}$}

\section{How to determine whether the parties lack legal capacity}

The second preliminary objection is lack of legal capacity, but Article 21 of the Code does not define the term. When a law is ambiguous, lawyers commonly look to the surrounding articles for guidance. Unfortunately, the articles immediately surrounding Article 21 provide little help. In fact, the only other article to reference legal capacity in the entire Code is Article 502, which states: "A minor, insane, idiot, interdicted and absentee cannot directly be a legal adversary." Presumably, then, Article 502 defines what it might mean to lack legal capacity.

Still, substantial ambiguity remains. How would you determine whether an individual is "insane" or an "idiot"? Are there clear standards that courts can or should use?

\section{iii. Inapplicability of the claim to the defendant: Article 21.3}

While Article 21.3 provides that "inapplicability of the claim to the defendant" is a basis for a preliminary objection, the Code does not detail any specific procedures the court should use to determine whether the claim is applicable to the defendant. Consider this: preliminary objections are distinct from the merits of the case. But when the court determines whether the claim is applicable to the defendant, does it not have to consider the merits of the case?

Imagine that you are a judge asked to decide whether the claim is applicable to the defendant. What criteria would you use? Is it enough for the plaintiff to show the defendant is the person named in the request letter?

\section{iv. Absence of documented proof of the possession of the immovable subject matter of the claim: Article 21.5}

If the plaintiff does not actually own or possess the piece of property that is the subject of the lawsuit, it makes little sense for a court to spend time and energy deciding the case. Thus, in the interests of judicial economy (defined as using judicial resources efficiently), Article 21.5 
allows the defendant to make a preliminary objection based on an "absence of documented proof of the possession of the immovable subject matter of the claim."

Imagine you are an attorney representing a defendant in a case concerning moveable property, such as a horse. The plaintiff alleges your client stole the horse and he is its rightful owner. Your client claims the horse is and always has been his property. What type of evidence would you offer in support of your preliminary objection?

\section{v. Claim preclusion: Article 21.4, Article 21.6, and Article 21.7}

One of the fundamental values of litigation is finality. Once a case has been decided and the appeals process is complete, the decision is final and the parties must abide by the judge's order. If a party goes to court with a claim that already has been decided, the defendant may make a preliminary objection under Article 21.4 .

Under Article 21, a case is to be dismissed if a court previously issued a legal ruling related to the issue at dispute between the parties (Article 21.4), if the case relates to another case that is currently under consideration by another court (Article 21.6), or if the case itself is under consideration by another court (Article 21.7). These objections can be grouped together in a type of objection called "claim preclusion." Because the claim has already been heard, the Code precludes the claim from receiving another hearing.

\section{Discussion Questions}

1. Consider why the Code requires wronged parties to file a claim within a certain period of time after the wrongful act. Can you think of scenarios in which statutes of limitations would actually be unjust?

2. If a party receives an unfavorable decision in a lawsuit and believes that the appeals process was unfair, can he ask another court to hear the case again? If not, is that fair?

\section{vi. The case being subject to the limitation period: Article 21.8}

A defendant can also make a preliminary objection based on the statute of limitations. Generally, plaintiffs must file a lawsuit within a certain period of time following the alleged wrongful act. Once this period of time (known as the statute of limitations) expires, the plaintiff has lost his opportunity to seek judicial redress.

\section{Recusal of Judges: Articles 65-78}

\section{Reading Focus}

Note that under Article 65 a judge "shall" recuse himself or herself under certain circumstances.

As you read the Code of Civil Procedure or other codes, pay attention to the use of "shall" versus 
"may." When someone "shall" do something, they are required to do so. When someone "may" do something, they are allowed to do so.

One of the keys to a fair trial is for the case to be heard by a disinterested judge. A judge who is related to one of the parties, or who has a financial or personal interest in the outcome of the case, might not be impartial. With this concern in mind, under certain circumstances, Article 65 of the Code requires a judge to recuse himself or herself.

Using the definition of "related" provided in Article 65.1, two or more judges who are related to each other cannot serve as judges on the same case (Article 66). Thus, if a brother and a sister are both on the panel of judges set to hear a particular case, one of the two would be required to step down from the case.

\section{Civil Procedure Code}

\section{Article 65}

The president and the members of the court shall each remove himself/herself from the composition of the trial and hearing of a civil action in the following situations:

1. If he/she is an interested part in the case before the court or if the claim is related to the principals and proxies, husband, wife or their relatives. For this purpose, "relatives" means brother and sister and their respective children (nephew/niece), uncle and aunt (on both the mother's side and the father's side), father-in-law and mother-in-law.

2. If he/she has written or signed a document related to the case before the court, or if he/she, acting as a prosecutor, has already made a judgment as to the subject matter of the claim or, as an expert or witness, has already expressed an opinion.

3. If there is a conflict between the president and the members of the court or one of the parties to the case.

4. If there is an existing enmity between the president and the members of the court or one of the parties to the case.

In addition, the judge can recuse himself or herself for reasons other than those outlined in Article 65 (Art. 67). Furthermore, the parties to the claim can request the exclusion of a judge (Art. 70) by submitting a "written and documented form to the court within three days prior to the commencement of proceedings of the case" (Art. 71). When one of the parties requests the exclusion of a judge pursuant to Articles 70 and 71, the judicial panel of the court conducts a hearing of the reasons for and against recusal (Article 72). If a majority of the judges on the panel vote for recusal, then the challenged judge must step down (Art. 72). If a majority of the judges vote against recusal, then the judge is permitted to remain on the case. If the judges are evenly divided, then "rejection of the judge is preferred" (Art. 72). Judges removed from the panel are to be replaced by another judicial panel (Art. 93).

Although both the plaintiff and the defendant are entitled to request the removal of a judge, he or she should carefully consider whether to make such a request. Under Article 77, "if the grounds for rejection of the judge are not proven, the court deciding that there is no proof to 
allow rejection shall impose a monetary fine of up to 3,000 Afghani upon the party requesting the rejection in bad faith (plaintiff or defendant)."

\section{Discussion Questions}

1. Without referring to the Code, can you think of reasons that a judge should recuse himself or herself from a particular case? Should a judge recuse herself if her son is a party to the case? What about her nephew? Or a family friend?

2. Read Articles 74 and 75, which also address recusal. Why do you think these articles establish separate procedures for when a party requests the removal of an entire panel of judges as opposed to the removal of a single judge?

3. Aside from the threat of a fine, what are some other, practical consequences that might result if a party requests the removal of a judge but it is determined that the judge should remain on the panel? Think about when you would request the removal of a judge who you believe has a conflict of interest. Might you decide not to request the removal of a judge even though you know the judge is biased?

\section{NOTICE, SUMMONS, AND APPEARANCE}

In order for the judge to question the parties and arrive at a fair and just decision, the parties ideally should be present. After hearing arguments from each party, the court is better equipped to issue a well-informed decision. In addition, a party who is not present during the court proceedings does not have the opportunity to challenge the other party's claims and may be at a serious disadvantage. For these reasons, the Code establishes rules requiring parties to appear in court.

\section{A. Plaintiff must appear and pursue claim in court}

When a plaintiff files a claim in court, it is his or her responsibility to pursue that claim; the court is a forum for claims to be heard, not a proving party. Within thirty days of filing a claim, the plaintiff must "follow his/her application in the court" or else the claim will be dismissed (Art. 153). In addition, Article 32 provides: "If the plaintiff does not attend the hearing of his/her claim for the second time and does not inform the court of his/her legal excuse, the court shall again issue a ruling of dismissal of the case." The rule is straightforward: if the plaintiff fails to appear two times in a row, his or her claim is dismissed.

The decision of a court to dismiss a case because of the plaintiff's failure to appear is subject to appeal (Art. 33) and, if reversed, the plaintiff is entitled to new proceedings (Art. 34) if he brings his claim within thirty days (Art. 35). 


\section{B. Notice to the defendant}

Imagine the following situation. One day, a message arrives at your home.

Dear Sir/Madam:

We write to inform you that the district court has determined that the property you hold in Kandahar rightfully belongs to Mr. Abdul Sahar. The court reached this decision after Abdul filed a lawsuit against you. Because thirty days have passed from the date of the court's decision, you are not entitled to an appeal and you must vacate your land immediately.

Sincerely,

The District Court of Kandahar

Abdul is your neighbor and, several months ago, he told you that he believes that the land you have been living on actually belongs to him. However, before receiving the message from the District Court, you were unaware that Abdul had initiated a lawsuit. Even though you have documents and witnesses to prove that the land actually belongs to you, it is too late. The court already reached a final, binding decision and you no longer have the right to an appeal because thirty days have passed from the date of the court's decision. Do you believe that this is a fair result?

To avoid exactly this scenario, Article 128 of the Code requires notice: "[t]he court shall directly inform the party to a claim or summon him/her through relevant authorities." While Article 128 is clear, several questions about the notice requirement remain. Think about what exactly the Code requires of the court. Does the court satisfy its duty to inform the party by attempting to contact him or her? Is it enough to write a letter or make a phone call? Should the court be required to send an agent of the court to the party's home? Is there a point at which the court satisfies its duty, even though it has failed to inform the party of the claim? Or is actual notice required?

The Code answers some, but not all, of these questions. Article 132 permits the court to "request in any manner possible, including telephone and telegraph, the presence of the parties to the claim, witnesses and experts." Article 134 obliges the Office of Summons and Appearance "to give the summons form to the relevant person or his legal representative, and to obtain his signature and agreement to appear." In place of a signature, an illiterate person may use his or her fingerprint (Art. 135).

The Code also defines how a court shall "summon" parties to a case. Under Article 131, a summons must contain: "(1) Name and address of the court; (2) Identity and accurate address of parties to the claim; (3) Date and time of presence; (4) Introduction of the issue; (5) Reminders to the person summoned regarding preparation and presentation of documents related to the issue; and (5) Warning about consequences of non-appearance."

If the person summoned does not appear even after receiving the official summons, "the request for his presence . . . is made for the last time through radio or a popular and widely- 
circulated newspaper" (Art. 146). The language employed by the Code suggests that the court must take this additional step to inform the parties of the lawsuit.

\section{Discussion Question}

What are the most reliable ways of informing a person in Kabul about a court claim? Does this differ in the provinces? What steps should the court have to take to fulfill its obligation to inform the party of the pending claim?

\section{Failure to Appear: Articles 130-150}

Although the Code includes a variety of procedures to ensure that all parties are informed of the proceedings, a case can proceed under certain circumstances even if the defendant is not present. If the party summoned by the court fails to appear and fails to provide a reasonable excuse, Article 147 provides that "the court shall issue judgments in abstentia regarding him/her."

\section{Key Concepts and Definitions}

"In abstentia" is a Latin phrase meaning "in one's absence." For a court to issue a decision "in abstentia" means it will issue a decision without the presence of one of the parties.

The court may also be required to appoint a representative to advocate on behalf of the absent defendant. Article 158 permits a close relative of the defendant to "assign a representative ... [to] proceed with the hearing of the claim." If the court is unable to contact the defendant's relatives, "the civil prosecutor is assigned as the representative of the absentee (party) and the claim is heard" (Art. 159).

\section{Discussion Questions}

1. Note that Articles 158 and 159 conflict with Article 147. While Article 147 allows the court to proceed with a claim without the presence of the defendant, Articles 158 and 159 contain robust protections for the interests of absent defendants. Turn to your statutory supplement to consult the relevant articles. How would you resolve this apparent conflict?

2. Think about the significance of holding a trial without the presence of the defendant. How might the defendant's absence impact his chances for success? Imagine that you are a lawyer representing a client who does not want to appear before the court. What advice would you give your client? 


\section{CONFLICTS OF LAWS: 1977 CIVIL CODE ARTICLES 23-35}

So far, this Chapter has examined how and where to file a lawsuit and the court's obligation to inform the parties of the pending claim. Once these preliminary requirements have been satisfied, the court turns to the merits of the case. To reach a decision, the court must apply the law to the facts of the case.

But how does the court determine what laws to apply? This question arises when two or more conflicting laws govern the same claim. For example, if an Afghan citizen and a French national enter into a contract, should the laws of Afghanistan or of France apply? A doctrine called "conflicts of laws" helps us answer this question and other questions like it. While the Code of Civil Procedure does not address conflicts of laws, the 1977 Civil Code contains provisions that govern conflicts of laws in a variety of contexts.

\section{Laws applicable to foreign nationals}

When foreign nationals do business in Afghanistan, are they bound by the laws of Afghanistan? If a foreign company has a dispute with an Afghan company or an Afghan citizen, do the laws of Afghanistan or the laws of the foreign government apply? According to Article 18 of the Civil Code, the law of Afghanistan applies to foreign companies and associations when those entities undertake "major activities" in Afghanistan.

\section{Contract claims}

As Afghanistan's economy grows and as the country continues to integrate into the global marketplace, Afghans will enter into contracts with foreign nationals on a more frequent basis. The 1977 Civil Code contains several provisions that determine which state's law applies when contract disputes arise.

For example, Article 28 of the Civil Code reads: "With respect to conditions relating to the form of contracts, provisions of the law of the state in which the contract is completed [executed] shall be applicable." Thus, if a contract is negotiated and signed in Afghanistan, the laws of Afghanistan govern the form of the contract. The obligations of each party often are more controversial than the form of the contract. Article 27 of the Civil Code states: "With respect to obligations arising from contracts, the law of the state in which parties to the contract reside shall be applicable."

\section{Discussion Questions}

1. Increasingly, Afghans will enter into contracts with foreign nationals. If a dispute arises as to the obligations that one party owes to the other under the terms of the contract, which country's laws should apply? Think about why you, as an Afghan citizen, would want the laws of Afghanistan to apply.

2. Conversely, why would a German citizen want the laws of Germany to apply? Are there circumstances under which Afghans would prefer to apply the laws of Germany? 


\section{Property claims}

Property claims, the most common type of disputes in the Afghan courts, may arise between Afghans and foreign nationals or between Afghans living in different regions of the country. While Afghan law applies to property disputes between Afghans and foreign nationals if the property is located in Afghanistan, it is less clear what law applies when there is no uniform national property law. If local Afghan property laws conflict, Article 26 of the Civil Code provides "the law of the locality in which the property is located shall be applicable, and with respect to movable property the laws of the locality in which the right of possession or dispossession is effected shall be applicable."

\section{Other claims}

While the Civil Code explicitly addresses which laws should apply in a variety of circumstances, conflicts of laws might arise in other circumstances as well. Where Articles 23-31 of the Civil Code do not address a particular conflicts of laws, "rules of private international law shall be applicable" (Article 32). Read the following excerpt to learn more about private international law.

\section{Key Concepts and Definitions}

Private international law is the body of conventions, model laws, national laws, legal guides, and other documents and instruments that regulate private relationships across national borders. Private international law has a dualistic character, balancing international consensus with domestic recognition and implementation, as well as balancing sovereign actions with those of the private sector.

Private international law, also known as conflict of laws, governs the choice of law to apply when there are conflicts in the domestic law of different countries related to private transactions. This means that there is a dispute or transaction that involves one of the following:

- what jurisdiction applies

- choice of law to apply

- recognition or enforcement of a foreign judgment.

National laws are the primary sources of private international law. However, private international law is also embodied in treaties and conventions (for example, the Hague Conventions on Private International Law), model laws, legal guides, and other instruments that regulate transactions. However, there is no well-defined body of private international law. Private international law deals with a variety of topics, such as contracts, marriage and divorce, jurisdiction, recognition of judgments, child adoption and abduction, and many other areas. Some view private international law as the business law of the world. 


\section{TRIAL PROCEEDINGS: ARTICLES 204-245}

\section{Reading Focus}

Before beginning this section, think about the procedures, if any, that should govern the trial phase of litigation. What role should judges play as the parties present their arguments? Should the Code of Civil Procedure require judges to conduct trials in a certain manner, or should such questions be left to the discretion of judges?

The preceding sections address the pre-trial phase of litigation: how to file a lawsuit, the bases for preliminary objections, and conflicts of laws. This section turns to the procedures that govern the trial phase of litigation, which is when the court hears the arguments advanced by each of the parties, weighs the evidence, and announces a decision. (Section VIII below addresses the procedures that apply to appeals, which follow the trial phase.)

The trial phase of litigation can be divided into two stages: the judicial proceedings (also known as pleadings) and the judicial discussions (also known as oral argument). During both phases, the court must follow rules that govern the submission of evidence and expert testimony to the court.

\section{A. Judicial Proceedings (Pleadings)}

Pleadings, which are formal documents filed with the court, state the parties' basic positions. Article 213.1, one of the most important provisions governing the trial phase of litigation, grants both the plaintiff and the defendant an opportunity to submit written arguments or pleadings to the court and submit evidence for the court to review. Pleadings and supporting documents must be submitted to the court before the judicial discussions begin so that the judges have an opportunity to review them.

The first pleading is the plaintiff's complaint (also known as the legal request letter), which sets out the plaintiff's version of the facts and specifies the damages requested. (The complaint is addressed in greater detail in Section III.A.) The complaint is the first and probably the most important pleading filed in any case; if there is no complaint, there is no case to be decided.

In response to the complaint, the defendant files an answer, which explains why the plaintiff should not prevail. The defendant's answer may offer additional facts to show the case should be decided in his or her favor, or plead an excuse. If the defendant pleads an excuse, he admits he has done what the plaintiff alleges, but he should not be held responsible because of other circumstances. For example, a defendant may claim he did the wrongful act under duress; in other words, someone forced him to do the wrongful act. Duress is just one example of an excuse. 
In some cases, the plaintiff may file a response to rebut claims made by the defendant in the answer. In addition, the defendant may file a counterclaim against the plaintiff, which asserts the plaintiff somehow wronged the defendant and should pay damages. The plaintiff should be allowed to respond to any counterclaims made by the defendant.

\section{Civil Procedure Code}

\section{Article 213}

If the parties to the claim appear in the judicial proceedings on the specified date, the proceedings shall be officially announced and the following steps shall be taken:

1. Following the claim of the plaintiff, the written defense by the defendant is recorded in a special form (a pleading form) and then the claim of the plaintiff and the defense of the defendant are read in the presence of the parties in the judicial session and the contents of the claim and defense are conveyed to the parties.

2. After the reading of the claim of the plaintiff and defense of the defendant, first the plaintiff is given time to explain the claim and the relevant documents, secondly, the defendant is given time to explain its response to the plaintiff's claim with presentation of documents.

3. The president of the session and members of the judicial panel shall question the parties about [any] lack of clarity and conflict.

4. The secretary of the session is obligated, following an order by the president of the court, to record the proceedings and explanations of the manner of removal of vagueness and conflict in the claim of the plaintiff and the defense of the defendant, and at the end of the trial, to get the record signed by the parties to the claim and by the judicial panel.

\section{B. Judicial Discussions (Oral Argument)}

After the pleadings have been filed and reviewed by the court, judicial discussions begin. All judges assigned to the case must be present during judicial discussions, or else the proceedings must be delayed (Article 214). At the commencement of the judicial discussions, the complaint and the defendant's answer are read aloud. Then, judges question the plaintiff and the defendant about their claims to resolve any ambiguities or inconsistencies (Art. 213.3). Judges also may question witnesses and other parties summoned to appear before the court.

\section{Civil Procedure Code}

\section{Article 237}

The judicial discussions contain statements involved in the case that take place in the following order:

1. Statements of the plaintiff or his/her legal representative.

2. Statements of the defendant or his/her legal representative. 
3. Statements of a third person who presents a separate request during the proceedings of the case.

4. The opinion of the prosecutor involved.

5. Other issues that assist the speedy trial.

Each of the parties involved in the case are permitted time to make statements in support of their positions in an order prescribed by Article 237.

\section{Evidence}

\section{What is evidence?}

Evidence is used to demonstrate or prove the truth of an assertion. Evidence can come in a variety of forms, depending on the type of claim at stake. For example, in a property case, the parties may want to show the court a deed to the land, if one exists. In a case concerning a will, the will itself is an important piece of evidence.

Article 281 states there are three sources of proof: (1) documents, (2) testimony of witnesses, and (3) evidences. Documents are either "official documents" or "customary documents" (Art. 282). These two types of documents "are of the same validity" (Art. 289) as long as they are deemed valid by the court. Testimony can come either from witnesses, who have first-hand knowledge of the facts of the case, or from experts, who testify based on their expertise. Finally, there are evidences, which are not defined in the Code; however, one might surmise "evidences" are tangible items that can be used to prove or disprove facts.

\section{When should evidence be presented to the court?}

Generally, parties must present evidence (which the Code refers to as "proof documents") before the judicial discussion begins. Once the judicial discussion begins, the court cannot accept proof documents that were not submitted to the court as part of the written pleadings unless: "(1) [t]he court is satisfied that delivery of the mentioned papers was not possible at that time; [or] (2) existence of another reasonable excuse based on non-presentation of the mentioned papers at that time" (Art. 216). Thus, as you can see, timely submission is of great importance.

\section{Authenticity of evidence}

Unless the court can be assured the evidence presented to it is authentic, it cannot be assured the verdict it delivers is fair and just. Evidence that is forged or falsified misleads the court and undermines justice. Thus, the Civil Procedure Code contains provisions that are intended to ensure the authenticity of evidence submitted to the court.

For example, the Code creates admissibility requirements. Article 287 states, "[e]dicts, official documents, absolute decisions and rulings of the court [are valid] if they are clear of forgery and falsification, and if they have been safely recorded in the government office of a judicial tribunal" (Art. 287). Customary documents are valid if they have been signed, or if the 
individual's seal or fingerprint has been placed on the document, and if the signature, seal, or fingerprint can be confirmed (Art. 289).

\section{Civil Procedure Code}

\section{Article 314}

Compliance with the following points is necessary in proceedings related to suspicious and forged documents.

1. Close attention to the hand-writing.

2. Close attention to the signature.

3. Close attention to the seal.

4. Close attention to the fingerprint.

5. Clearing and erasure and re-writing without correction.

6. Protrusion without seal and signature.

7. Photos of those included in the security document.

8. Difference in the original and the record of the security document.

The Code also contains strict regulations on the submission of evidence from outside the country or prepared in a different language. Under Article 307, "documents that have been prepared outside the country can be valid only when the said document has been prepared and signed by one of the political missions of the Republic of Afghanistan and the Foreign Ministry has also officially assured of its accuracy." If a party wishes to submit a document that has been prepared in a foreign language, he or she must "present the original document simultaneously with its certified translation to the court" (Art. 308). If the opposing party or the court questions the accuracy of the translation, "a new translation of the document is made by the court at the expense of the person presenting [the document]" (Art. 308).

\section{Who decides claims of inauthenticity?}

If one of the parties wishes to challenge the authenticity of the opponent's evidence, he or she must do so at the Primary Court, which is charged with deciding claims based on "dubiousness and forgery of . . . official documents" (Art. 298). But the court does not necessarily have to rely on one of the parties to challenge the authenticity of the evidence presented. Rather, the court also may act sua sponte, or on its own accord (in Latin); according to Article 303, "If on the face of it a submitted document of one of the parties to the claim appears doubtful in the eyes of the court, the court can officially demand a copy of it from the place that has prepared it." The decision of the Primary Court deeming a particular piece of evidence authentic or inauthentic is subject to appeal (Art. 301).

\section{Witness Testimony}

Just as there are special rules that govern the authenticity of documents, there are rules designed to ensure witnesses provide true and accurate testimony to the court. Courts will allow 
the parties to call "less than twenty five persons" (Art. 333), who are required to take an oath before testifying (Art. 50.1 Interim Criminal Code for Courts), and the court must allow the plaintiff three opportunities to call witnesses (Art. 330.2). Witnesses must give their testimony "in the presence of the parties" to ensure that information is available on an equal basis (Art. 322) and their identity must be revealed to all parties (Art. 323).

\section{Discussion Questions}

1. Think about the reasons underlying Articles 322 and 323. Why is it important for witnesses to testify in open court?

2. Why does the Code require that witness identities be revealed? Are there instances in which these provisions should not apply?

In addition, principles of Islamic law govern witness testimony. According to the Code, "[t]he amount of testimony and its conditions are subject to the rules of the Islamic law" (Art. 321.4). In addition, "[t]esting the character of obligated witnesses and the manner and conditions of the test are subject to the rules of Islamic law" (Art. 337.1).

\section{E. Expert Testimony}

Like evidence, expert testimony is used to establish the truth of a party's claim. Each party may call expert witnesses to testify before the court. Experts are professional persons who have sufficient expertise and experience in specific fields (Art. 4.12). The parties to the claim may object to the qualifications of an expert and, if "the grounds for rejection appear to be justifiable, the experts cannot express an opinion in the matter again" (Art. 183). Expert testimony must be presented in written form to the court and the opinion is read aloud during the judicial discussions. It is important to note the court is not bound by an expert's opinion. Rather, as it does with other witnesses, the court may question an expert's opinion and find it either persuasive or unpersuasive (Art. 190).

\section{F. Burden of Proof}

Trials are not like mathematics or science. In other words, judges often have to decide cases based on subjective criteria, such as whether a witness appears to be telling the truth. In some cases, both the defendant and the plaintiff might have plausible arguments. Who wins the case if both sides have a good case? The answer depends on who bears the "burden of proof."

Under Article 280, "If the defendant denies (the claim), the burden of proving the claim shall be upon the plaintiff." This means the plaintiff has the obligation of proving the allegations concerned in the case. But the Civil Procedure Code does not say exactly how high a burden the plaintiff has to meet. A few scenarios are clear. For example, if the judges deem the defendant's case to be stronger than the plaintiff's, then the defendant prevails. In addition, if the plaintiff and the defendant present equally plausible claims, the defendant would win the case. 
But the Code provides no guidance as to whether to apply (1) a preponderance of the evidence standard (meaning that one side has more evidence in its favor than the other, even by the smallest degree), (2) a clear and convincing evidence standard (establishing the truth of a disputed fact by a high probability), (3) a reasonable doubt standard (requiring proof of such a convincing character that a reasonable person would not hesitate to act upon it in the most important of his own affairs), or (4) some other standard. An argument can be made that the failure of the Code to provide guidance on this matter is a harmful omission. If the standard of proof is not specified, it opens the door for inconsistent, and perhaps arbitrary, judicial decisions. This impacts due process. For example, if similar cases come to two different courts, the judge in one might find that the plaintiff must win by only a preponderance of the evidence, while the judge in the other might find that the plaintiff must win by a clear and convincing standard potentially leading to different outcomes for the two plaintiffs simply because of which court they were in.

\section{Discussion Questions}

1. With a partner, write down the three different burdens of proof listed in the paragraph above. Now decide which one is the highest (that is, the most difficult to meet), which one is the lowest (that is, the easiest to meet), and which one is in the middle. Now think of other possible standards of review. Should the same standard apply to all cases? If so, why? If not, why not?

2. How can the proper standard be determined if it is not provided for in the Code?

\section{G. Duration of Trials}

By default, trials cannot last longer than four months, but judges have the discretion to extend the duration of proceedings as necessary (Arts. 200 and 201). Once the trial is completed, whether after one day or one year, "the right of the parties to give statements ends" (Article 242) and the judges deliberate in private (Art. 243). Once the judges have reached a decision, they announce the judgment to the parties (Art. 245).

\section{SETTLEMENT AND JUDGMENT}

The ultimate goal of a lawsuit is to achieve a result that is fair and according to the law. In fact, one might argue that all of the procedures contained in the Code were drafted to ensure the court reaches an equitable result. Litigation ends in one of two ways: settlement or judgment. 


\section{A. Settlement: Articles 230-232}

Once two parties have turned to the courts to settle a dispute, it may seem unlikely that they will reach an amicable agreement, which is known as a settlement. But settlement may remain a possibility, at least in some cases, even after litigation begins. In fact, Article 230 requires the court to "recommend the assignment of conciliators in cases where the court senses willingness on the part of the parties for settlement." In Article 231, the Code details how settlement is to take place, depending on when the parties reach an agreement.

\section{Civil Procedure Code}

\section{Article 231}

1. If the parties to the claim settle their differences prior to the commencement of the claim and the proceedings, their settlement is put in writing and their dispute is brought to an end.

2. If the settlement takes effect during the proceedings and the trial, the settlement is recorded in the decision and a judgment is issued allowing the settlement and an end to the dispute between their parties.

\section{B. Judgment: Articles 246-266}

Parties turn to the courts to obtain a reasoned judgment based on the applicable law. Thus, "[i]f the parties do not agree to settle (their dispute), the court shall proceed with the matter and shall issue a decision accordingly" (Art. 232). After reviewing the pleadings, relevant proof documents, and oral statements made by the parties during the judicial discussions, judges deliberate privately and issue a decision.

All members of the judicial panel must participate in the decision, which must be announced publicly (Art. 42), but only a majority need to agree to issue a decision (Article 250). Thus, at least two judges on a three judge panel must agree to issue a decision. A judge who disagrees with the conclusion of the majority must file a dissenting opinion that explains his or her reasons for not joining the majority (Art. 251).

The decision, which is in written form, must contain certain basic elements, including "the introduction, description, reasoning, conclusion and the text of the judgment" (Art. 254). The Code contains specific requirements for each of the judgment's five components. The introduction must include basic information about the plaintiff and defendant, details about the court, and the date of the decision (Art. 255). The descriptive part of the decision summarizes the facts of the case, the claims made by each party, the testimony of witnesses, and the trial proceedings (Art. 256). The reasoning addresses the merits of the case and the arguments that the court found persuasive (Art. 257). In the conclusion, the court announces the restitution or damages that it requires the parties to pay and can assess court costs (Art. 258.3 and 258.4). (Court costs may be expensive; they may include attorneys' fees, fees for filing documents, and other fees.) "The text of the judgment must be clear" (Art. 260) and is "announced to the parties 
of the claim without delay" (Art. 261). Pursuant to Article 266.1, the decision of the trial court becomes final when the time allowed for an appeal has elapsed.

Although the judgment marks the end of the trial phase, it does not necessarily mark the end of the case. When the judges announce their decision, they also must explain the time period for complaints and appeals (Art. 244). The complaint and appeals processes allow the losing party to seek further review of his or her claim.

\section{Discussion Questions}

1. Imagine you are a judge sitting in the District Court. The plaintiff's claim and the defendant's answer have been filed and each party has submitted proof documents to the court. A date has been set for judicial discussions, but before that day arrives you receive a letter from the parties indicating that they have reached an agreement. What procedures must you follow under Article 231?

2. Pursuant to Article 252, the deliberations are not to be disclosed to the public. Can you think of reasons that the drafters of the Code would have wanted to prevent the public from learning what the judges say during their deliberations? Would it be preferable to allow the public to be present during deliberations? Make a list of pros and cons, divide the class in half, and have a debate.

\section{APPEAL}

Almost inevitably, one party will be dissatisfied with the ruling of the lower court. According to Article 53 of the Law of the Courts, the decision of the Primary Court is final when both parties agree with the decision, "when the time for appealing has expired, when the disputed property is worth up to 100,000 Afghanis, or when a cash fine of 50,000 Afghanis is issued."

But the Primary Court's ruling is not always final. In other cases, the dissatisfied party can ask the Court of Appeals (or Superior Court) to review the lower court's decision. Appeals courts are split according to subject matter so that an individual must appeal to the court that fits the subject of their case. There are five dewans in the Court of Appeals: General Criminal, Public Security, Civil and Family, Public Rights, Commercial, and Juveniles. The Court of Appeal may affirm the Primary Court's decision, reverse the trial court's decision, or remand the case to the Primary Court based on that court's legal reasoning of the decision and the facts of the case.

\section{A. Grounds for Appeal}

A party can appeal the lower court's decision based on several grounds, as set forth in Articles 399 and 400 of the Code. Review these provisions before proceeding.

\section{Civil Procedure Code}




\begin{tabular}{|c|c|}
\hline \multicolumn{2}{|c|}{ Article 399} \\
\hline \multicolumn{2}{|c|}{ The grounds for invalidity of a decision are as follows: } \\
\hline 1. & Lack of the essential pillars of justice in the decision. \\
\hline 2. & Absence of capacity on the part of one of the parties to the claim to litigate. \\
\hline 3. & $\begin{array}{l}\text { Issuance of a judicial decision without the possibility of proof or against objective reality } \\
\text { regarding the subject matter of the claim. }\end{array}$ \\
\hline 4. & Issuance of a decision by a judicial panel without jurisdiction. \\
\hline 5. & Issuance of a decision by a court without jurisdiction. \\
\hline \multicolumn{2}{|c|}{ Article 400} \\
\hline \multicolumn{2}{|r|}{ The situations where a decision is overruled are as follows: } \\
\hline 1. & The decision was not based on evidence. \\
\hline 2. & Absence of explanation for situations which are necessary to clarify the case. \\
\hline 3. & Non-conformity of the reasons contained in the decision with the situations of the case. \\
\hline 4. & Inappropriate use of the rules of the law. \\
\hline 5. & Issuance of a decision of dismissal due to absence of the plaintiff. \\
\hline 6. & Other decisions that can legally form the grounds for overruling the decision. \\
\hline
\end{tabular}

As you will have noticed, some of the grounds set forth in Articles 399 and 400 are quite specific while others are quite vague. For example, in most cases, a trained jurist should be able to determine whether the trial court lacked jurisdiction. Similarly, when a decision is based on no proof at all, or where the lower court misapplied the law, the appellate court will reverse.

Now consider what it means for a decision to "lack of the essential pillars of justice" (Art. 399.1). What does the phrase "essential pillars of justice" mean to you? Similarly, what does it mean for there to be an "absence of explanation for situations which are necessary to clarify the case" (Art. 400.2)? Will judges interpret these phrases consistently? If not, what impact will such diverse viewpoints have on the ability of parties before the court to predict the outcome of a case?

\section{B. Filing an Appeal}

Even where the trial court committed clear error, appellate courts do not spontaneously reconsider trial court rulings. Rather, to initiate an appeal, a party must file a request letter with the higher court within a specified time.

\section{Interlocutory Appeals}

Recall that the defendant may challenge the court's ability to hear a case through what is known as a preliminary objection. Once the trial court has ruled on the defendant's objections, the party dissatisfied with the ruling has twenty days to present its objections to the superior court (Art. 23). If neither party appeals within the twenty days following the trial court's decision, the decision becomes final. After the appeal is filed, the opposing party (in other words, the party that was successful at the trial level) has fifteen days to respond to the appeal (Art. 24), or else the appeal is granted. 
Note that an appeal of a ruling on a preliminary objection takes place before the trial court issues a judgment on the merits of the case. This is called an "interlocutory appeal." If the Code did not allow interlocutory appeals for preliminary objections, the parties could spend a great deal of time, energy, and money litigating a case, only for the appellate court to determine that the trial court did not have jurisdiction. In other words, allowing interlocutory appeals for preliminary objections improves judicial economy.

\section{Appealing a decision on the merits}

To appeal a judgment, the appealing party (known as the appellant) must file an official request letter with the Court of Appeals. The request letter must contain the "actual issue and the judgment of the lower court" (Art. 369) and must be signed by the appellant or the appellant's representative. The appealing party then must file two copies of a "detailed objection" within twenty days after the initial notice of appeal, or "complaint," has been filed (Art. 377). If the detailed objection is not filed within the twenty day period, the appeal is "not justiciable," which means the judgment of the lower court stands and is not subject to further review by the Court of Appeals (Art. 371).

Article 378 of the Code requires the detailed objection to contain certain key pieces of information, including a summary of the trial court's decision, reasons the appellant believes the trial court reached an erroneous decision, and supporting documents. This background information enables the appellate court to review the lower court's proceedings. The court studies the background information and prepares a report, which is read at the commencement of the appeals proceedings (Art. 392.1). After the report is read, the appellate court will "hear the explanations of the parties involved in the case" (Art. 394).

\section{Civil Procedure Code}

\section{Article 378}

Written complaint or detailed objection shall contain the following matters:

1. The name of the court to which the complaint or objection has been made.

2. The identity of the complainant.

3. Summary of the decision that is the subject of the complaint or objection.

4. The name of the court issuing the decision that is the subject of the complaint.

5. Reasons for inaccuracy of the decision.

6. Demand of the complainant or the person/party objecting.

7. Papers and documents containing the list of contents for the attachment of complaint or objection. 


\section{Considering and Resolving an Appeal}

While the appellant's written objection may help the appellate court form its decision, the appellate court may reverse the trial court for reasons not contained in the appellant's written objection (Art. 393.2). The Code permits the appellate court to review all of the lower court's decisions, including whether the lower court correctly applied the law and whether the evidence submitted supports the trial court's decision (Art. 393.1).

The appellate court can decide a case in one of four different ways. If the appellate court finds that the trial court did not err, then the trial court's judgment is affirmed and the parties must respect its decision (Art. 398.4). If, however, the appellate court finds that the trial court erred, it can send the case back to the trial court for a retrial (this is known as a "remand") (Art. 398.1), send the case back to the trial court for more fact-gathering (also known as a "remand") (Art. 398.2), or correct the decision of the trial court (this is known as a "reversal") (Art. 398.3).

\section{Civil Procedure Code}

\section{Article 398}

The higher court after the preliminary proceedings of the case shall have the following jurisdiction at the final stage:

1. Sending the case to the authorized court for retrial in case of invalidating the decision of the lower court.

2. Deciding to issue a new decision of the lower court or in case of a need for return of the case to the setting court for the purpose of gathering reasons and further research for a new proceeding.

3. Decisions of lower courts clear of situations of being invalidated and overruled, but involving mistakes and errors of numbers and figures shall not be invalidated or overruled by the higher court. They are returned to the lower court only for the purpose of correction and removal of defect.

4. Approval of the decision of the lower court, in case its conformity with the law is established as a result of review.

\section{Standard of Review}

Trial courts decide two principal types of questions: questions of law and questions of fact. When the trial court misapplies the law-for example, by requiring a defendant to pay a fine of 500,000 Afghanis even though the law allows a maximum fine of 10,000 Afghanis-it commits an error of law. When the trial court makes an implausible determination of fact-for example, by finding that a defendant is the rightful owner of a piece of property even though all of the evidence shows otherwise-it commits an error of fact.

Nowhere does the Civil Procedure Code address the standard of review that appellate courts are to use for either questions of law or for questions of fact. The degree of scrutiny an 
appellate court uses to review a lower court's decision is called the standard of review. Typically, appellate courts apply a more exacting standard of review for questions of law than for questions of fact. Thus, while an appellate court might review questions of law as if the trial court had never decided the question (this type of review is called de novo, meaning "anew" in Latin), it might review questions of fact for clear error. Under these standards, the appellate court would apply its judgment to decide the question of law, regardless of the trial court's decision. But the appellate court would reverse the trial court on a question of fact only if the trial court's finding is entirely groundless. The rationale for this different standard is that trial courts are in the best position to determine facts, since they see witnesses and pieces of evidence directly.

\section{Discussion Questions}

1. Without guidance from the Civil Procedure Code, by what standard should appellate courts review lower court decisions?

2. Do you expect judges to adopt a standard approach to appellate review? What are some of the drawbacks of not applying a uniform standard of review?

\section{E. Appeal to the Supreme Court}

If the losing party in the case after the Court of Appeal's decision wishes to appeal, he or she may do so to the Supreme Court, although the Supreme Court will only review the decision for compliance with the law. In addition, according to Article 404 of the Code, the appeals court's decision to overrule the lower court's decision "is not subject to complaint and is final." A decision by the Supreme Court is final and cannot be appealed.

\section{DECORUM AND JUDICIAL ADMINISTRATION: ARTICLES 56-64}

\section{Reading Focus}

Why does the Code contain rules that govern the behavior of lawyers in the courtroom? What authority should judges have to enforce these rules and punish individuals who do not obey them?

Throughout the world, courts of law are places where tradition, formality, and decorum are valued. In many places, courts require that attorneys wear certain attire in the courtroom and prohibit them from wearing jackets or hats. Courtroom rules may forbid the use of cell phones and cameras, require attorneys to sit and stand at particular times, such as when addressing the judge, and prohibit eating and drinking in the courtroom. 
Similarly, the Civil Procedure Code establishes rules that are intended to ensure order in the courtroom. Because at least some judges expect attorneys to abide by these rules, it is important that you learn them. In addition, judges have the power to punish individuals who disobey the rules and the Supreme Court has the power to create new rules for effective court administration.

\section{A. Courtroom Decorum}

\section{The rules of decorum}

Under the Code of Civil Procedure, the judge wields substantial control over the behavior of people in his or her courtroom. While the public is permitted to attend hearings (Art. 41), all attendees must refrain from disturbing the order of the hearing, or else face sanctions. When the judges enter the courtroom, "all those in attendance shall stand up and when the judges take their seats, they shall sit down" (Art. 47). Unless otherwise instructed by the judge, all partiesincluding the plaintiff, the defendant, attorneys, witnesses, experts, and interpreters-are required to stand up when speaking before the court (Art. 56).

\section{Sanctions for violating the rules of decorum}

A person disturbing "the order of the hearing" is entitled to a single warning (Art. 57); thereafter, he is subject to sanctions. The judge has the power to expel individuals who do not follow courtroom decorum and who cause a disturbance (Art. 57). Besides the power to expel unruly individuals, the judge may impose a fine not to exceed 3,000 Afghanis or a jail sentence of up to one week on a plaintiff, defendant, or attorney who disturbs the "orderly conduct of the hearing" (Art. 58). A person who "commits the crime of obscenity or a misdemeanor during the hearing, he/she shall be punished by the court according to the provisions of law" (Art. 61).

Under Article 62, "The court shall determine the mandatory punishments provided for under [the Code] . . . and the judgment of the court to this effect shall not be subject to appeal." However, before the end of the proceeding, the judge may decide to cancel the punishment (Art. $63)$.

\section{B. Judicial Administration and Judicial Qualifications}

The Supreme Court is responsible for the administration of the courts. Under Article 504, "The Supreme Court is obligated to enact for the purpose of effective implementation of the rules of this code special rules and regulations that have been approved by the high council of the Supreme Court regarding conditions for accuracy of the claim." The Supreme Court also can propose laws on judicial affairs in the National Assembly and discipline judges.

Under Article 58 of the Law of the Court, judges must be a citizen of Afghanistan for at least ten years, should not have been convicted of any crime, must hold a degree in law or Islamic law from a religious studies center, and be 25 years of age or older. 


\section{CIVIL PROCEDURE IN PRACTICE}

\section{Discussion Questions}

1. What are the most important qualities that judges should possess?

2. In addition to the qualifications established by Article 58 of the Law of the Court, can you think of additional qualifications that you would require of judges?

\section{Reading Focus}

As you examine "civil procedure in practice," think about ways in which the way civil procedure is actually practiced departs from the provisions of the Code. Consider ways in which the practice of civil procedure improves upon the provisions of the Code and ways in which applying the provisions of the Code would be beneficial.

In the preceding sections, we learned about civil procedure by studying the various articles that govern the litigation process from start to finish. However, for lawyers, judges, and policymakers, an equally important endeavor is to study how civil procedure works in practice. This Section provides a brief overview of how civil procedure works-or does not work-in two of the most common types of cases: property and family law.

\section{A. Property Claims: Administrative and Judicial Procedures}

Afghanistan's civil courts have a great deal of experience dealing with property disputes. Afghanistan's civil courts are more accessible than the Special Land Dispute Court because they are more numerous and they exist even in the country's rural areas.

If one chooses to handle a property dispute in civil court, one must follow a formal process. The first step is to submit an official one-page request form to the Law Department of the Ministry of Justice (called Hoquq). The form requires the plaintiff to describe the claim as well as some other basic information. The Hoquq then will contact the local police department, which in turn contacts the defendant in the action. During this phase of the process, the Hoquq may also gather additional information about the case.

The Hoquq and the police department will often attempt to settle the dispute through mediation or by encouraging the parties to settle the dispute through informal mechanisms (discussed below). If the dispute cannot be settled through mediation or if the parties choose not to use informal mechanisms, the case is referred to a court. In the case of property disputes, this will likely be the city, municipal, district, or sub-district court (or if the case involves returning refugees, it could be referred to the Special Land Disputes Court). 
Afghans voice many of the same complaints about the civil courts, however, as they do about the Special Land Dispute Court. The courts can be "slow, expensive, and corrupt." According to a recent report, judges appointed by the Kabul government are often holdovers from the Taliban era whose knowledge of the law (governmental or Islamic) is deficient and who are widely reputed to demand bribes. Given the nature of the appeals process, cases can drag on indefinitely even after they reach the Supreme Court level in Kabul because decisions of that court often throw the case back to the beginning or make a judgment that is locally unenforceable. Refusal to accept civil verdicts is common.

This report reflects the views of many who have observed the Afghan civil court system in action. But there is no need to become discouraged because of these problems. All countries in the world have at one time or another faced obstacles such as corruption or a lack of adequately trained professionals in the judicial system. It is for this reason-to improve the system over time-that ambitious young people in Afghanistan like you must take up the charge of becoming informed about the legal process and perhaps even become legal professionals.

\section{B. Family Law: Articles 101-120}

Disputes within families are among the most common cases brought before the civil courts. Articles 101-120 address the civil court procedures for family law cases, and Article 101 defines family law as follows:

\section{Civil Procedure Code}

\section{Article 101}

The following matter shall fall within the family cases:

1. Marriage and rights arising from it.

2. Rights arising from marital relationships.

3. Financial disputes arising from marital relationship.

4. Claim related to lineage.

5. Issues related to protection and maintenance of child.

6. Dissolution of marriage for whatever reason.

7. Issues related to an absentee and missing husband.

8. Other issues that are considered as part of family cases according to the provisions of law.

Just as there is an alternative procedure for property claims, the Code of Civil Procedure calls for the creation of specialized family courts in every district. However, as of 2005, the only functioning specialized family court was at the Supreme Court in Kabul. In the rest of the country, the civil courts, as well as shuras and jirgas, handle family law matters in addition to their other case obligations.

Where specialized courts exist, how do they work? And how do most citizens of Afghanistan handle family law matters in practice? 


\section{Civil Procedure in Specialized Family Courts}

The specific family court at the Supreme Court in Kabul operates in the following manner (according to the interviewed judges from the Supreme Court):

Registration of all complaints to the court in the registration book (daftar endrā $\breve{g}$ )

General evaluation meeting of the judges in order to classify the registered complaints.

Court procedure to resolve the dispute.

Court judgment.

Appeal to the provincial high court within one month after the issuance of the district court verdict.

Appeal to the Supreme Court within two months after the provincial high court has issued its judgment.

In practice, however, the courts are not the first mechanism to deal with a legal case. This is done by the local assemblies, the jirga or shura. The expressions jirga and shura denote the same mechanism: jirga is Pashto, shura Dari. People favor addressing the local jirga as the first step for the investigation and settlement of legal disputes. Even when a case is referred to the court, the court refers the case back to the jirga in order to find an informal solution first. The preference to address a local jirga is especially clear in family law matters and where one party is a woman. Addressing an official institution can cause serious harm to the prestige of both parties. Going to court is considered a shameful act for women.

Example 1: A man was absent for seven years. His wife wanted to get a divorce. Her parents-in-law were not behaving properly towards her. Therefore, she complained to the Department of Women's Affairs and asked for help. But the parents tried to prevent her from doing so: they told her that their son was still alive and warned the legal officials not to intervene in this case. This is common in most parts of Afghanistan, especially if a husband is absent and if he doesn't have any brothers. The parents will do everything to prevent their daughter-in-law from suing for divorce.

Furthermore, it was reported that abuses perpetrated by family members against other family members - including rape, mistreatment, house imprisonment, and even murder - do not even reach a jirga. Rather they get buried within the house boundaries. Very rarely do such sensitive matters reach the jirga and/or the courts. Confusion about these institutions and their authority is prevalent among the population (Max-Planck Institute).

\section{CONCLUSION}

This chapter has explored the underpinnings of civil procedure in Afghanistan's courts. While studying procedural requirements can be tedious, you now understand that the line between substance and procedure is often a fine one. As you learn more about the current system and specific areas of law, remember that there may be significant deviations between civil procedure as it is written and civil procedure as it is practiced. You should also consider the basic 
goals of civil procedure: efficiency, predictability, and fairness. How well does the current Civil Procedure Code incorporate these goals? As Afghanistan considers reforms, what changes can or should be made to improve the Code? By understanding how the courts are intended to operate and how they operate in practice, you - as Afghanistan's future leaders-can make a significant contribution to your country's judicial system.

\section{Hypothetical Questions}

1. Ishaq hails from Kabul and Abdul is from Mazar-i Sharif. The two men have a dispute about who owns a piece of land in Kabul. Abdul claims to hold a deed to the land, but Ishaq has several witnesses who will testify that he has lived on the property in Kabul for many years. Abdul files a legal claim to evict Ishaq from the land. Where should the case be heard? Can you think of reasons that a court in Kanduz or Herat, for example, should not be allowed to hear the case?

2. Khaterah owns and operates a successful business selling soaps. Hohberht, an international diplomat who has lived in Afghanistan for two years while working at the German Embassy, thinks that the soaps would make a wonderful gift to take to his family and friends in Germany. Hohberht tells Khaterah that he would like to buy $\$ 500$ of her finest soaps. Khaterah tells Hohberht that the soaps will be ready in one week and he agrees to pay her then. One week later, when Khaterah goes to give Hohberht his order, she discovers that he has gone back to Germany. With no place else to sell such a large amount of soap, Khaterah decides to sue Hohberht to recover damages. What court has jurisdiction?

3. Imagine that you are a judge in Kabul. An energy company called Frenergy is owned by French nationals and is headquartered in Paris. Frenergy generates annual revenues of \$100 million, 99\% of which comes from its activities in Europe. However, Frenergy also has a contract to supply electricity generated by solar panels in Kabul. The revenue from this contract (roughly $\$ 1$ million) accounts for the remaining 1\% of its annual revenues. A case involving Frenergy comes before you. You must decide whether Frenergy has "major activities" in Afghanistan. What factors would you consider? What additional information would you like to have to help you decide?

4. Imagine that you are a lawyer and your client's case is before the court. You are convinced that your client is right, but you are worried that the court will decide against your client because you and one of the judges are not on good terms with each other. You ask for the judge to recuse himself, but he refuses. One day in court, the judge accuses you of causing a disturbance even though you have done nothing out of the ordinary. The judge threatens to fine you three thousand Afghanis. How would you handle the situation? What is your obligation to your client, and how can you further his interests while protecting yourself? 


\section{Sources Consulted}

American Society of International Law (ASIL). 2009. ASIL Electronic Guide to Electronic Resources to International Law. http://www.asil.org/pill.cfm.

Kagan, Robert. 2006 In Barbara Babcock, Toni Massaro \& Norman Spaulding, Civil Procedure: Cases and Problems. Aspen.

Max-Planck Institute. Family Law in Afghanistan. http://www.mpipriv.de/ww/en/pub/research/research_work/foreign_law_comparative_law/islami c_legal_system/family_law_in_afghanistan.cfm.

Max-Planck Institute. 2005. Family Structures and Family Law in Afghanistan: a Report on the Fact-Finding Mission to Afghanistan January. http://www.mpipriv.de/shared/data/pdf/mpi-report_on_family_structures_and_family _law_in_afghanistan.pdf (last accessed July 3, 2009).

University of California - Berkeley Law Library. Researching International Law. http://www.law.berkeley.edu/library/classes/iflr/pil.html. 


\section{CHAPTER 4: PROPERTY LAW}

\section{INTRODUCTION}

Consider a small piece of land in Kabul with a home built on top of it. The property law of Afghanistan tells us who the property belongs to, how it may be used, and to what extent an owner may prevent other people from using it. Property law also covers transfers, telling us how the property may be disposed of by one owner and acquired by a new owner. Property law is significant because people generally strive to own property, they prefer that property ownership be secure, and there is evidence that secure ownership is best achieved through a functional system of property law. Therefore, a complete explanation of the property law of Afghanistan calls first for a discussion as to why a functional system is essential for secure property ownership, followed by a discussion of the specific mechanics of Afghan property laws.

While there are many different types property, this chapter will discuss land and immovable structures built upon land. This chapter will first address how establishing a system of secure property ownership can further a country's goal of developing economically. There is evidence that a functional property law system is a prerequisite and catalyst to economic development. The discussion will then turn more specifically to the four major aspects of property law-acquisition, disposition, use, and exclusion. The property law of Afghanistan is laid out extensively in the Civil Code of Afghanistan. Like most systems of property law, the laws as they are written provide the framework for a detailed and highly formalized system of transfers (acquisition and disposition), use, and exclusion. How the property law system functions in reality, however, paints a contrasting picture and illuminates the tension between formal and informal systems of property ownership.

Afghanistan's property law system faces three key challenges that are specific to the current situation in Afghanistan. First, Afghanistan has a weak federal government with limited capacity that has not yet established its role in promoting the rule of law. Therefore, property laws may not be readily enforced, and when they are, they may not be enforced in a uniform way. Second, the political future of Afghanistan is unclear; thus laws could change quite dramatically in the near future. People are hesitant to make large investments in light of a high probability of future instability. Third, as a post conflict society, Afghanistan has a large displaced population and disputes often arise between those currently in possession of property and those who may have had claims to the property in the past but were forced to evacuate the region. There are many situations where two or more people have good claims to a single piece of property and the law is expected to help resolve the dispute efficiently and fairly. You should keep these challenges in mind as you read through the material in this chapter.

\section{Property Ownership and Economic Development}

In this chapter we first look at why a functional system of property law is thought to be economically important to economic development in Afghanistan. This section of the chapter is divided into five subsections: Security, Market Access and Credit, Increased Ownership, 
Formalization Attempts and Failures, and Credit Challenges. In the Security subsection we will look at the types of security benefits a property owner may enjoy when his or her ownership rights are secure and recognized by the relevant governing body. In the Market Access and Credit subsection we will look at how secure systems of property ownership may open up access to markets and credit, and the resulting implications. In the Increased Ownership subsection we will look at why increased private ownership may benefit society, as well as in what ways governments may work to increase legally recognized private ownership. In the Formalization Attempts and Failures subsection we will look at past attempts to formalize property law systems and the subsequent failures, thinking critically about why these attempts failed, and what would be necessary for an attempt to be successful. In the Credit Challenges Subsection we will discuss how even with secure property ownership, there are often traditional and cultural barriers to credit access.

The purpose of this section is not to make the argument that formalized property law systems are essential for economic development to take hold. Rather, this section looks at the world as it is, and extrapolates what this means for Afghanistan. All developed countries happen to have formal property law systems in which ownership claims are secure and recognized by the government. The purpose of this discussion is to look at why secure property ownership is important, the different ways it has been achieved or failed to be achieved, and what this means for Afghanistan. Once we complete our discussion on property ownership and economic development we will turn to a discussion on the mechanics of Afghan property law.

\section{Afghan Property Law}

As we turn our discussion to the mechanics of Afghan property law, we will look first at the foundational components of Afghanistan's property law system. These foundational subsections are: The Scope of Property Rights Under the Constitution of Afghanistan, Dispute Resolution, and Registration. In the first section, we will look at the scope of property law under the Constitution and the basic rights of private owners. In the Dispute Resolution subsection we will look at different ways that property disputes are resolved in Afghanistan. In the Registration subsection we look at the two prevalent property registration systems, and see how Afghanistan fits into this scheme.

We will then turn to a discussion of the four key components of property law-rules on acquisition, disposition, use, and exclusion. This discussion is divided into three subsections: Transfer of Property, Use, and Exclusion. The Transfer of Property subsection will look at property acquisition and disposition by focusing first on inheritance, followed by a discussion on property sales and purchases. The Use subsection will discuss what property owners may do with their property with a focus on nuisance, contracts, water rights, mineral rights, takings, adverse possession, and restitution. This is a lengthy section that explains to what extent a property owner may use his or her property in a way that affects others, what rights they have with regard to natural resources located on or within his or her property, and the extent to which property owners may claim government owned or abandoned property. The Exclusion subsection will discuss the level at which property owners may exclude others from their property with a focus on easements granting use rights to non-owners. Each section will fully explain new concepts with which the reader may be unfamiliar. 


\section{PROPERTY OWNERSHIP AND ECONOMIC DEVELOPMENT}

Property law is important because of the real benefits systems of secure property ownership have on people's lives. Secure property ownership can be attained through formal and informal property law systems as long as the system is functional, but there is some evidence that formal property law systems bestow greater benefits. At the most basic level, a functional property law system gives people security by allowing them to own the home in which they live. There is strong evidence that when ownership claims are secure, property owners may be more productive in the workforce and more willing and able to invest in their property and families. ${ }^{1}$ Property ownership is also beneficial because it is a basic form of investment that in turn grants access to other forms of investment. There is evidence that under formal property law systems, owners have greater market access than under informal systems, including access to credit. ${ }^{2}$ Lenders are able to be secure that if the borrower is unable to repay a loan, the debtor possesses stable interests in property that can be used to satisfy the debt. Increased market access and access to credit give property owners the opportunity to use their property to help them become even better off economically.

\section{Key Concepts and Definitions}

Lender: The entity, a person or an institution, that lends money to a borrower, with the expectation that it will be paid back

Borrower: The person or institution that receives money from the lender, with the obligation to pay it back in the future

Credit: The provision of money by a lender to a borrower, with the expectation of future payment by the borrower to the lender

Capital: Accumulated possessions and property that have some economic value, such as a piece of property

Collateral: Capital that is used to secure an extension of credit

Mortgage: An extension of credit against property that functions as a lien until it is fully paid for

Lien: The security interest created by a mortgage; i.e. a lender has a lien on your property until you finish paying off your mortgage

Title: A legal document that constitutes a right to property ownership

\footnotetext{
${ }^{1}$ Klaus Deininger \& Gershon Feder, Land Registration, Governance, and Development: Evidence and Implications for Policy, 24 The World Bank Research Observer 233, 250 (2009).

${ }^{2}$ Hernando De Soto, The Mystery of Capital: Why Capitalism Triumphs in the West and Fails Everywhere Else (2000).
} 


\section{A. Security}

In a secure system of property ownership a property owner will be able to easily and effectively prove that he or she owns a particular piece of property, and the government will act to enforce ownership.

In a system where property ownership is not secure, property law may be inadequate or applied unequally. Where property law is inadequate, a property owner may not be able to produce sufficient evidence to validate her claim of ownership. She will risk losing her right to own property if her claim of ownership is challenged. For instance, she may have purchased the property under an oral agreement and lack any documentation evidencing her claim of ownership. In contrast, under a secure property ownership system, if the owner is challenged she will be able to quickly point to a legal document that proves the property is hers, and she will face no real risk of losing the property. Even if property law is adequate it must still be applied equally. Consider a situation in which a property owner has strong evidence of her claim to a piece of property, but her ownership claim is challenged by an individual who is wealthy, powerful, and connected to the government. She may still worry about losing the property if the government system is corrupt. A secure system will recognize a valid claim of property ownership regardless of the identity of the challenger.

An additional benefit of a secure system of property ownership is thought to be that because the owner is required to spend only a minimal amount of time defending her property rights, she may have more time to work and earn a living for her family, and her family may be better off as a result. When people are secure in their ownership claims, they may also be more willing and able to make investments in their land and their families. ${ }^{3}$ There is some evidence that when property ownership is secure, owners not only take the logical step of making further investments in their property, but they also take the seemingly unrelated step of spending more money on their families, particularly for education. An alternative explanation for this phenomenon is simply that property ownership makes people wealthier, and when people are wealthier they tend to spend more on their families. In systems where property ownership is not secure, would-be owners are simply acting as non-owners, thus they have not reaped the economic benefits of property ownership. Likewise, would-be owners are less likely to improve property by making repairs and taking other steps to add value. When property ownership is not secure, informal owners are hesitant to invest in their property because of concerns that the property law system is either inadequate, applied unequally, or both.

A secure system of property ownership also makes property transactions more efficient. When a prospective buyer is interested in a particular piece of property he can be sure that the seller is the legally recognized owner. This saves the buyer time and money he would otherwise have to invest simply to verify the legitimacy of the transaction. This savings benefits the property owner as well, because he would likely have been asked to bear some of these costs. Aside from decreasing the transaction costs incurred from researching a property's ownership

\footnotetext{
${ }^{3}$ Klaus Deininger \& Gershon Feder, Land Registration, Governance, and Development: Evidence and Implications for Policy, 24 The World Bank Research Observer 233, 250 (2009).
} 
history, a transaction that is legitimate on its face virtually eliminates the risk that a future dispute will arise regarding the validity of the new owner's claim to the property.

While property owners and prospective property owners are better off under a secure property ownership system, there is evidence that society as a whole becomes better off as well. A key characteristic of societies that are well off economically is that ordinary members of society are able to start businesses and invest in their communities. New businesses do not only give an advantage to the business owners themselves, who become wealthier personally, but also to other members of society who may now take advantage of additional goods and services. What follows is a discussion of how secure systems of property ownership allow property owners to make these types of business investments through credit.

As you read, keep in mind that secure property ownership does not necessarily require formal recognition by the government, or even a formal property law system. Communities may successfully regulate and enforce property ownership at the local level. Nonetheless, all developed nations that have undergone industrialization have formal property law systems, and the bulk of private property is formally recognized by the government. Thus, as we proceed, we should keep in mind what has worked to help other countries prosper economically, how the situation in Afghanistan differs, and how to adapt the property law framework utilized by other countries to fit the situation in Afghanistan.

\section{B. Market Access and Credit}

Over the last few decades, many governments in developing countries have worked to formalize and strengthen their property law systems. This is in large part because of the theory that large scale economic development will take hold under a formal property law system. In The Mystery of Capital, Hernando De Soto ${ }^{4}$ proposes that formalizing property rights will strengthen weak financial systems by putting capital to work on the open market, leading to economic development. De Soto describes capital as the typical houses that people live in, and the fields where crops are grown, or animals graze. Many people in Afghanistan own this type of property. De Soto argues that a large portion of property in the developing world is dead, meaning that it is not being used to its full economic potential. De Soto argues that owners with formally recognized property have greater access to markets and wealth. For a country to develop, owners without legally recognized claims to property must gain formal recognition. For this to be feasible, the formal system must adopt informal mechanisms. Thus, the formal system's notion of recognized property ownership must expand, ensuring secure ownership rights for a greater proportion of the population.

\footnotetext{
${ }^{4}$ Hernando De Soto, The Mystery of Capital: Why Capitalism Triumphs in the West and Fails Everywhere Else (2000).
} 


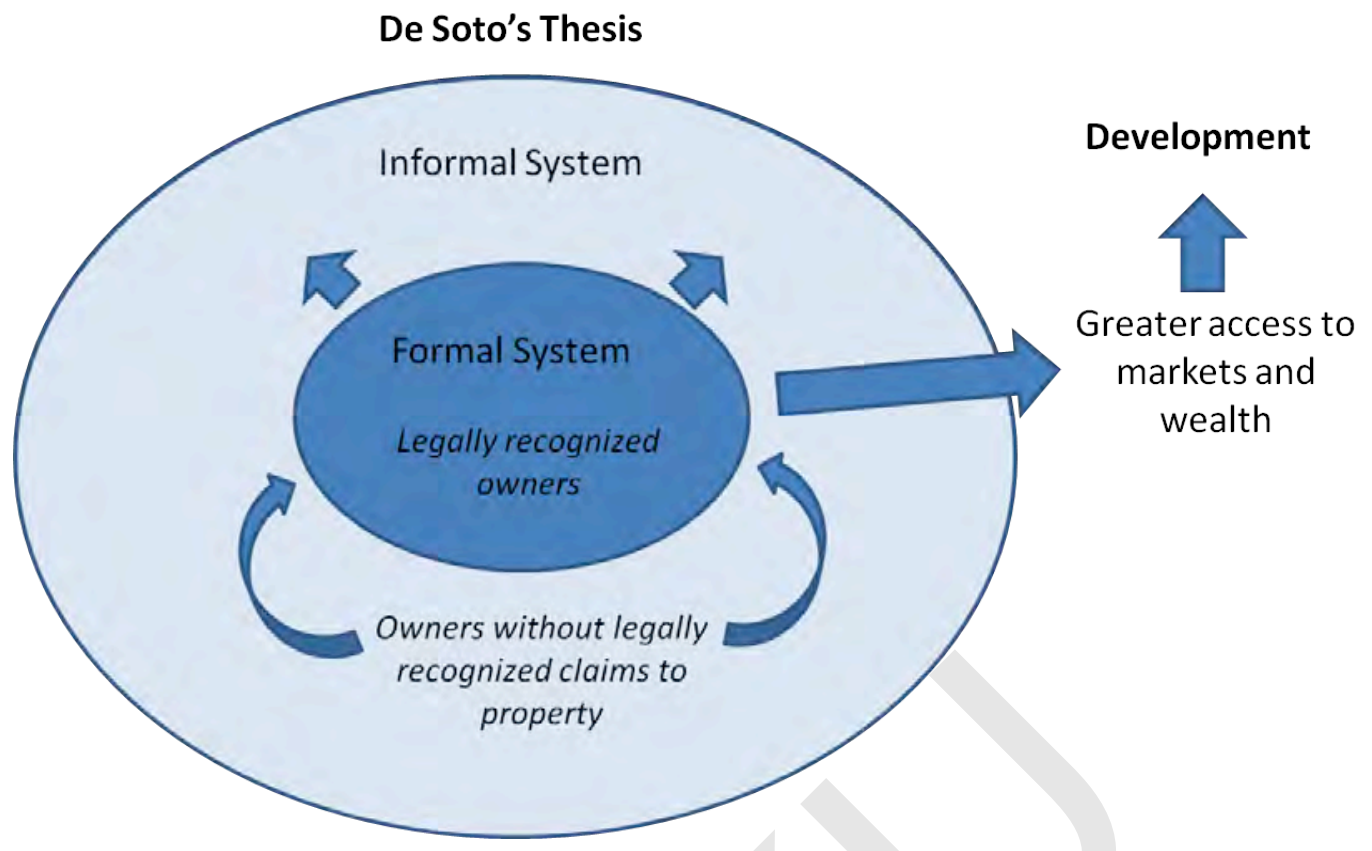

Property is being used productively, according to De Soto, when its owner has legitimate access to the market economy. To have legitimate market access, a claim to a piece of property must be formally recognized by the government. Access to the market grants the property owner two distinct advantages. First, he may access the judicial system to seek remedies pertaining to his property. For instance, if someone trespasses on his property and steals his crops, his claim against the trespasser will be recognized in a court of law. This might not be the case if his claim to the property was not formally recognized by the government. Second, he may more readily gain access to credit. Credit is money borrowed based on the value of the property and put to a new economic use. For instance, a farmer may secure credit for a wheat field that he planted by hand, and use that credit to invest in new farm equipment to increase the yield, and make planting more efficient, ultimately making an even larger profit. The process of securing credit through a formal lender can be complicated, and requires a functional property law system. De Soto points out that virtually all Western countries have such a system, which employs six key mechanisms whose results have benefitted these countries economically ${ }^{5}$ :

\section{Six Property Law Characteristics of Developed Countries}

First Mechanism: Keeping written property records

Result: Information about property is transmitted broadly and over time

Second Mechanism: Integrating property records into a single system

Result: Dramatically decreases costs because all property records are located in the same place

\footnotetext{
${ }^{5}$ Hernando De Soto, The Mystery of Capital: Why Capitalism Triumphs in the West and Fails Everywhere Else 49$62(2000)$.
} 
Third Mechanism: Subjecting property ownership systems to impersonal law; i.e using standardized civil law, rather than subjecting people to less predictable customary and informal outcomes

Result: Property ownership arrangements are standardized, thus owners are released from restrictive and politicized local arrangements

Fourth Mechanism: Property is evaluated to determine its economic value on the open market

Result: Property related transactions and remedies become more streamlined and transparent

Fifth Mechanism: By formalizing recordkeeping, the names of owners are attached to pieces of property

Result: Creates a network of individually identifiable and accountable business agents

Sixth Mechanism: Continuous tracking of property contracts

Result: Ensures that transactions are accurate and secure

In summary, developed countries all have property law systems that share several common characteristics. Property records are recorded; there is a single property registration system; property law is applied uniformly; property is transparently evaluated to determine its market value; records tie ownership to specific individuals and entities; property contracts are tracked continuously. This list is not exhaustive; there are many other factors that are important to economic development. These simply happen to be some of the prominent shared characteristics of property law systems in developed nations. Can you think of other factors that may make a property law system successful?

Consider the piece of land with the home built upon it that we discussed at the very beginning of this chapter. Let us now look at the process that the owner of this property must go through to gain access to credit under a formal system of property ownership. In this case the property owner hopes to obtain credit from a bank or another lender to start a new business. He would like to open a factory that manufactures athletic shoes, which he believes will be a highly profitable business in Afghanistan. He wants to build the factory on his property and has just enough space to do so. To decide whether the property owner is a good candidate for credit, the lender will first determine how much the property is worth. This value helps determine how much money the property owner can borrow from a bank against his property. The lender will be able to lend the property owner less money than what the house and land are worth and use the property as collateral against the loan. Using the property as collateral means that if the property owner does not pay back the money that was lent to him, the lender may be able to take the property from the owner to compensate for its loss. Before credit is extended to the property owner, he and the lender will agree to the terms of repayment and set a repayment schedule.

Should the property owner fail to pay the lender back in a timely manner, the government will enforce the law against him, typically through the court. That is, the lender will be able to take the property owner to court to recover the lost money that the property owner failed to pay back to the lender. If the property owner does not have the money to pay the lender back, the 
lender will be awarded ownership rights to the property. This system creates incentives for the lender to make loans, because the lender knows that if the property owner fails to repay the loan, it can take the property from him. The lender will then sell the property to earn back the money it should have received from the property owner and will not be any worse off for having extended credit. The following diagram illustrates the lending process for an extension of credit in the form of a mortgage, where a person's home is used as collateral.

De Soto argues that if lenders know they will be able to recover money that was lost from a defaulted loan they will be more eager to lend. This argument seems to favor a formal system of property ownership. In reality, the ability to recover on a defaulted loan does not necessarily require a formal system because the ability to recover lies somewhere on a continuum and depends on a variety of factors. Even an informal system of property ownership may provide solid assurances of debt recovery. Furthermore, the financial infrastructure required to estimate default debt is not completely tied to the formality of the property law system. For instance, even if the formal property law system were to be implemented perfectly overnight, it might take longer to develop the financial infrastructure that would allow this type of lending to take place. When lenders are willing to extend credit, people are able to obtain that money and start businesses. In a functional property law system they are also able to gain access to the legal system to protect their property and their businesses. De Soto says that this jumpstarts economic development and raises the standard of living for all. Consider De Soto's thesis as you read the following discussion on the recent mortgage crisis in the United States

\section{Mortgage Crisis in the United States ${ }^{6}$}

In the United States people typically purchase homes using mortgages. A mortgage is simply an extension of credit that must be paid back to a lender at a fixed rate, usually over a thirty year period. People use their newly purchased homes as collateral to obtain mortgages. This practice became problematic several years ago when people began borrowing increasingly risky mortgages that often charged very high interest rates after a set period of time. On top of this, the economy turned downward and the value of people's homes began to fall. Not only were payments on mortgages often very expensive, but people who wanted to sell their homes to pay off their mortgages could not because homes had decreased in value below the value of their mortgages. When people fell behind on payments lenders took them to court to gain ownership of the property. The loss of ownership in this scenario is called foreclosure. Many people lost their homes to foreclosure and the value of all homes decreased substantially. Does what happened in the United States disprove De Soto's thesis? Why or why not?

\section{Increased Ownership}

There is some evidence to support the idea that secure property ownership improves the quality of society at large both because more people are able to own property, and more people

\footnotetext{
${ }^{6}$ Vikas Bajaj \& Louise Story, Mortgage Crisis Spreads Past Subprime Loans, New York Times, Feb. 12, 2008 available at http://www.nytimes.com/2008/02/12/business/12credit.html.
} 
are recognized as property owners. ${ }^{7}$ First, secure owners tend to invest more in their property and overall in their lives. Second, because people are secure in their property, they no longer need to spend excess time defending that property, and are able to become more economically productive. Consider also the following discussion on the tragedy of the commons theory, and how increased property ownership, and recognition of ownership claims may benefit society. Think critically about whether there are other equally good resolutions that do not involve increased ownership.

\section{The Tragedy of the Commons}

The Tragedy of the Commons was a 1968 article published by Garrett Hardin ${ }^{8}$ arguing that when people have open access to resources they will act rationally to deplete them, even though such depletion of resources is not anyone's long-term interest. To better understand the mechanics of this theory, consider a situation in which there is public canal surrounded by a vast expanse of farmland divided into many different plots. Suppose also that the farmers each grow crops that are heavily dependent on irrigation. Each farmer should ration his or her water to ensure that the water does not run out for everyone. Because each bears all of the benefit and none of the consequence, however, each farmer will act in his or her own self-interest to deplete the water. This theory has been used to argue for increased regulation of open access resources, and even increased privatization of land. Imagine a similar scenario in which there is a plot of public land open for grazing animals. Without strong regulation, the land might quickly become overgrazed and useless for all. Perhaps it would have been more economically beneficial to simply divide up the land into private plots. Keep this theory in mind as you read the following section, and also keep in mind that this theory pertains to open access resources and not common property. Common property, such as a plot of land shared between several families, is not typically subject to over-exploitation because of strong community ties among property owners and group regulation.

The following examples demonstrate evidence of the positive impact, both economically and otherwise, of systems of secure property ownership in developing countries - formal systems in particular. ${ }^{9}$ As you read the examples, think critically about the positive impacts that are attributed to secure property ownership in two ways. First, think about whether a formal system of property ownership is required or whether these same benefits could result from an informal property law system. Second, think about whether the benefits necessarily flow from secure property ownership at all or whether they are caused by other factors.

\footnotetext{
${ }^{7}$ Klaus Deininger \& Gershon Feder, Land Registration, Governance, and Development: Evidence and Implications for Policy, 24 The World Bank Research Observer 233, 247-256 (2009).

${ }^{8}$ Garrett Hardin, The Tragedy of the Commons, 162 Science 1243 (1968).

${ }^{9}$ Klaus Deininger \& Gershon Feder, Land Registration, Governance, and Development: Evidence and Implications for Policy, 24 The World Bank Research Observer 233 (2009). Examples were drawn from the entire article.
} 


\section{Benefits of Secure Ownership?}

Better conditions: In Argentina, property under title was kept in much better condition than property that was not held under title, and those who owned this property had a better outlook on life.

Improving Governance: Computerizing property registrations systems greatly reduced the amount of bribes taken by government officials in India, saving people money, and increasing tax revenues.

Environmental impacts: In Uganda, establishing ownership rights increased soil conservation and investment in trees. When people own a piece of land they try to take care of it. On the other hand, when nobody owns land, no one has a personal stake in improving or even maintaining it.

Increased investment: In Argentina and Peru, people with titled property were more willing to invest in that property than people who did not have title to their property.

Benefits for women: In Nepal, women who owned property were able to achieve the same success as women with an additional four years of education.

\section{Discussion Questions}

1. Think about property owners that you know; are they generally better off economically than those who do not own property? Why or why not?

2. What role could the government play in creating a more secure property ownership system in Afghanistan? What strengths and shortcomings does the government have in this regard?

\section{Extending Ownership Rights}

There are two ways for a government to extend ownership rights over property-it may formally recognize ownership for someone who already has a property claim, or it may distribute land to someone without a preexisting ownership claim. The first way a government may extend ownership rights is by granting formal ownership recognition to a person who already believes he owns a piece of property. In Afghanistan there are property owners who have had a particular piece of property in their family for generations. They may have never been issued a formal document by the government, or the formal document may have been destroyed or lost. There are also owners who may have purchased a piece of property informally. By providing them with legal documents these landowners gain increased security in their claim of ownership over land that they already treat as their own.

The second way to extend ownership over a piece of property is to distribute land to people who either never owned land, or were displaced from the land that they owned previously. This involves giving people a recognized claim to land that was previously un-owned 
or redistributed from existing owners, and control of the property, in the hopes that the new owners will establish themselves on that land and use it productively.

The distinction between these two methods of extending ownership is important because they bring about different types of benefits. There may be fewer economic benefits associated with land distribution, than by simply formally recognizing existing ownership claims. There have been some instances in which governments have had a political interest in ensuring that the recipients of distributed land maintain ownership. ${ }^{10}$ In these situations, lenders may not trust the courts to seize land that was put up as collateral for a loan should the property owners default. Nonetheless, there is no evidence that the claims of lenders are less likely to be enforced simply because property ownership was obtained through a distribution scheme. Furthermore, when land is simply distributed, it may lack the infrastructure required to make it both economically valuable and productive. See the following discussion on Afghanistan's government run land distribution program.

\section{Afghan Land Distribution Program ${ }^{11}$}

In 2005, the Afghan government began a scheme to distribute land to landless returnees and internally displaced people. The program was extremely popular with Afghans and received approximately three hundred thousand applications. The government divided up plots of land to give away. The individual pieces of property were located in a remote area without direct access to roads, water, electricity or other services. Think about why the government would be interested in administering such a program. What broader societal goals might government officials have had in mind when they started this program? What else might the government want to provide to these new landowners besides the title deeds that would be helpful? When answering these questions, think about the new owners' ability to build on the land, to receive water and energy, and their likely proximity to their place of employment.

\section{Formalization Attempts and Failures}

While secure property ownership can be achieved through both formal and informal mechanisms, governments have overwhelmingly pursued formal property law systems in hopes that they will provide economic benefits. For formal property law systems to be functional, they need to be easy to use and the government needs to provide the services mandated by law. The government must provide a system of property registration and the ability to seek legal redress if there is a violation or dispute. Furthermore, the formal system must be more efficient than the prior informal property law system for people to actually choose to use it. When instituting formal property law systems, however, governments tend to focus overwhelmingly on property registration. Governments have both attempted and failed to implement formal property law systems by simply formalizing the law and instituting massive land titling programs in the hope

\footnotetext{
${ }^{10}$ Klaus Deininger \& Gershon Feder, Land Registration, Governance, and Development: Evidence and Implications for Policy, 24 The World Bank Research Observer 233, 255 (2009).

${ }^{11}$ For more information on this program read Afghanistan at the Crossroads: Afghan Returnees Assess the Lay of the Land, United Nations Human Rights Council, Nov. 19, 2008, http://www.unhcr.org/49240b682.html.
} 
that once all land is registered, economic development will simply take hold. ${ }^{12}$ These land titling programs failed in a two major ways. First, they failed to register much of the land. Second, the countries that instituted the titling programs did not experience economic development as a result. Consider this as you read about a recent attempt to register property in Indonesia.

\section{A Recent Registration Attempt in Indonesia ${ }^{13}$}

In the last decade, a large tsunami ravaged parts of Indonesia. Indonesia lacked a formal property registration system mapping out the exact specifications of people's property. When the tsunami struck it not only wash away people's homes, but also any evidence of property boundaries. Implemented in 2005, the Reconstruction of Aceh Land Administration System (RALAS) project seeks to restore property rights using participatory processes. Community members decide jointly on the specifications of particular pieces of property and the Land Administration Agency maps the property and awards title to the owner. This project aims to grant titles to 600,000 landowners. As of 2006, roughly 11,000 titles were ready to be distributed. The project was slated to run until 2008. It is highly unlikely that this project came close to meeting its target.

Large-scale property registration failures have led many to question whether formalizing property law systems really leads to economic development. There are four primary reasons that critics believe formalization does not lead to economic development. ${ }^{14}$ The first is that it is difficult to formalize property law and the positive effects from formalization attempts are limited. Perhaps the best method of formalizing property law has yet to be attempted. Rather than focus overwhelmingly on registration, governments might focus on implementing a holistically functional system. On the other hand, implementing a functional property law system all at once would require an enormous amount of economic resources and skilled people to implement the new legal system. Or perhaps the stronger critique is that property law cannot be formalized in a vacuum. If there are other problems adversely affecting a country's economic situation, the country may simply not be able to develop economically until conditions improve altogether.

The second critique is that people have diverse interpretations of property rights based on their specific backgrounds. A person might actually consider herself to be the owner of a piece of property even though she has no formal documentation. Is this enough? What if she acts exactly as an owner would? What if she is able to secure credit without a title? Furthermore, in the

\footnotetext{
${ }^{12}$ Klaus Deininger \& Gershon Feder, Land Registration, Governance, and Development: Evidence and Implications for Policy, 24 The World Bank Research Observer 233 (2009).

${ }^{13}$ Reconstruction Of Aceh Land Administration System (Ralas), The World Bank: Project Operations, http://web.worldbank.org/WBSITE/EXTERNAL/PROJECTS/0, contentMDK:20877372 menuPK:64282137 page PK:41367 piPK:279616 theSitePK:40941,00.html (last visited May 16, 2011).

${ }^{14}$ Scott Shackelford, The Promise and Peril of Property Rights Formalization 23-39 (Jan. 9, 2009) (unpublished paper on file with Erik Jensen of Stanford Law School).
} 
developing world many people rent or lease property rather than owning it. Would formalizing property rights benefit countries that have a large proportion of renters?

When property owners are secure in their ownership claims, the property is worth more to them because they are not worried that they will lose their claims unfairly. Similarly, increased formality in the property law system may lead to increased formality in rental agreements between landlord and tenant. These agreements may become stricter and less amenable to renegotiation. For instance, an agreement in an informal system may be oral, requiring that the tenant pay rent on a month-to-month basis, and allow the tenant the option to move out whenever they would like. Even if the tenant fails to pay rent, there may be very little a landlord can do to seek redress. In a more formal system the agreement may require that the tenant sign a year-long rental agreement; if the tenant chose to move out early, the landlord may utilize the formal legal system to seek redress for the broken contract. Likewise, a tenant who is being overcharged by their landlord may have little redress under an informal system, whereas under a formal system they will be able to seek legal redress against their landlord. In general, however, the formal system tends to empower landlords who typically have greater wealth and access to the legal system than renters.

The third critique is that past approaches have been focused on implementing a formalized property system from the top down. The highest levels of government simply decided to implement land registration programs and hired people to register property. Very little work was done to see what informal property law mechanisms were already available, and how those might be incorporated into the formal system. The better approach may be to develop political coalitions at all levels of society to ensure that people are working together to bring about comprehensive reform, and that the reform actually makes sense by taking into account systems that are already in place. Can you think of any systems that are available at the local level that help people resolve property disputes? How might these be incorporated into the formal system? What are the benefits and disadvantages of these systems?

The final critique is that a formalized property law system may not be as good as local systems. Customary laws may be more inclusive and protective of group ownership and minorities, while formalized property law systems focus almost exclusively on individual owners. Consider a situation in which an entire village is suffering from the behavior of a neighboring village. We will consider an example later in this chapter in which one village cut off the water supply to a downstream village. In that situation, the dispute between the two villages was resolved through informal mechanisms. Leaders from the two villages were able to meet and come to an agreement. Likewise, individuals who lack financial resources may fare better in an informal system than a formal one. Later in this chapter we will consider a case in which a woman was left out of the inheritance when her father passed away. In that situation the formal court system was unable to resolve the dispute efficiently and she gained a satisfactory result through the informal system. In your experience, which type of system functions better to protect the rights of property owners? Why?

The counter argument to these critiques is that formalized property law systems are not inherently flawed, but efforts to create formalized property law systems are flawed. Formalized property law systems replace existing informal mechanisms. Governments have failed to 
recognize and incorporate informal property ownership mechanisms that would add efficiency to the formal system. For instance, a property owner's formal ownership paperwork may have been lost or destroyed, yet that does not necessarily mean that he should lose his land if there is a competing claim for the land. Were a court to require a property owner to travel for five days, with five witnesses with a fifty percent chance that his ownership claim will be validated, a property owner would choose this only if it were more efficient than using the informal system. If the informal system requires that the same property owner spend only one day in a shura with the same witnesses with a fifty percent change that his ownership claims will receive local recognition he may choose this option. A government in the midst of reforming its property law system might find ways to incorporate this informal mechanism into the formal system to increase efficiency and make the formal system more attractive. If the formal system has too many steps, or is simply too expensive, people may choose to not to use it, and informal mechanisms will continue to dominate.

One thing that is certain is that it is difficult to achieve a functional formal system of property law. Scholars have no clear explanations for why these systems emerge where and when they do. Many governments and organization have undertaken expensive efforts in good faith to formalize their country's property law systems, only to see those programs end in failure.

\section{E. Credit Challenges}

One of the advantages of a formalized property law system is that by establishing secure ownership, lenders are more comfortable extending credit. Nonetheless, even a functioning property ownership system does not guarantee access to credit. Here are several factors that may inhibit economic growth in this way. The factors listed below may have such an effect:

\section{Factors Inhibiting Credit Use ${ }^{15}$}

Tradition: People may not be accustomed to borrowing money through a lending institution, such as a bank. They may prefer borrowing from individuals who they know already because they feel the terms of the agreement are fairer and that they will face less drastic consequences if they fail to honor the agreement. Some may even prefer not to borrow money at all. Given the recent mortgage crisis in the United States that was discussed previously, there is certainly some benefit to people living within their means. Do you know anyone who is opposed to using credit? If so, what are their reasons for feeling this way?

Risk: Property owners may not want to use their home as collateral for credit because if they fail to pay back the loan, they may lose their home. Think about a homeowner you know. Why might they be opposed to using their home as collateral to receive credit? What about if someone owned two pieces of property and only wanted to use one as collateral - might this be different?

Ineffective Government: Lenders may not want to extend credit if they do not believe the government is capable of foreclosing on property and enforcing judgments. If you ran a lending institution that was trying to make money by extending loans to people, what would you want

\footnotetext{
${ }^{15}$ This information was obtained from conversations with Afghans and various written resources on Afghanistan.
} 
the government to guarantee before deciding whether or not to extend credit in a particular case? What other government mechanisms could you look to for assurance if the court system was not effective?

Apathy: Even when people are wealthy enough to obtain credit and invest in a new business or endeavor, not all of them are motivated to do so. Imagine that you are a high level elected representative. What would you do to persuade your constituents to use credit to invest locally? What incentives could you give them? What challenges would you face?

\section{Religious Concerns about Credit $^{16}$}

One concern about securing credit is that it conflicts with customary and religious rules against usury. These restrictions prohibit a lender from charging interest on a sum of money they lend to a borrower. Because so many people are interested in securing credit, especially to secure a mortgage to buy a home, there is at least one form of credit that has been developed to comply with Islamic practice. Credit extended to purchase a home is called a mortgage. A bank in the United Kingdom is offering mortgages that comply with Islamic requirements. To obtain a Islamic mortgage, the buyer puts down a small deposit for the home they want to buy. The bank then purchases the rest of the home. The buyer leases the home from the bank, and with every monthly payment, gains more ownership over the home. Once the buyer finishes paying the bank back, the home belongs to the buyer.

\section{Discussion Questions}

1. If property owners can prove quickly and with certainty that they own particular pieces of property, how does this benefit them and their families?

2. If a property owner is able to access credit from a lending institution to build a new factory, what factors might she worry about if she used her home as collateral?

3. What are some of the challenges to implementing a secure property ownership system? Who might be opposed to such a system?

4. Do you believe that an ideal property ownership system should be run more centrally by the national government, or left to local communities for administration? What are the benefits and consequences to each type of system?

\footnotetext{
${ }^{16}$ For more on Sharia mortgages offered in the United Kingdom read What are the Sharia Mortgage Criteria, Mortgage Help Desk UK, http://www.mortgageman.co.uk/faqs/hsbc-sharia-criteria/.
} 


\section{AFGHAN PROPERTY LAW}

We will now turn our discussion from the importance of property law to the structure of functioning systems of property law. Property law typically covers four key areas: acquisition, disposition, use, and exclusion. Because acquisition and disposition both involve transfers of property ownership, we will combine these two areas for the purpose of our analysis. Before we discuss these four areas, we will discuss property registration, which is critical to each. Registration addresses the types of records required for property ownership and how to update those records upon transfer. Laws on property transfer (acquisition and disposition) explain how property is purchased or passed down to a new owner. Property use details the permitted uses of a particular piece of property. Exclusion deals with the extent to which a property owner may exclude others from their property. The following is a short introduction to property rights as laid out by the Constitution of Afghanistan, followed by a discussion of each of the areas of property law.

\section{A. The Scope of Property Rights under the Constitution of Afghanistan}

Before an individual purchases or receives property and uses it in the way her or she sees fit, that individual must be entitled to a legal right to own property. Not all countries entitle their citizens to such a right. The scope of property law in Afghanistan is laid out under Article 40 of the Constitution. This Article contains five major provisions on property law that delineate the scope of the right to acquire, use, and exclude from property:

\section{Constitution of Afghanistan}

\section{Article 40}

\section{Property is immune from invasion}

Commentary: A property owner has control over his own property. If a person's property is invaded, he must have access to legal recourse to stop the invasion, or to receive a remedy for an invasion that has already occurred.

\section{No person shall be forbidden from acquiring and making use of a property except within the limits of law}

Commentary: People are allowed to purchase and use property so long as they follow the law. If a piece of land is for sale, a person should be able to go through the legal process to purchase it. Once she owns the land, she should be able to use it for any purpose she would like, so long as that purpose is lawful.

3. Nobody's property shall be confiscated without the provisions of law and the order of an authorized court. 
Commentary: Confiscating a piece of property from a property owner must be done in accordance with the law. This means that a piece of property may only be taken from someone if one of the laws of Afghanistan allows this result. Furthermore, there must also be an order by an authorized court permitting confiscation of the property.

\section{Acquisition of a person's property, in return for a prior and just compensation within the bounds of law, is permitted only for securing public interests in accordance with the provisions of law.}

Commentary: Acquiring a person's property must only be done in the public interest and in accordance with the law. Therefore, a person seeking to purchase a piece of land may not use it for purposes that go against the public interest or violate the law. Likewise, the government may only expropriate land in the public interest.

\section{Inspection and disclosure of a private property is carried out only in accordance with the provisions of law.}

Commentary: People are secure from giving away information about their property unless the law requires disclosure. For instance, a property owner needs only to allow property inspections that are set forth under the law, as the government does not have the power to inspect people's property whenever it deems appropriate.

The Constitution states that the Afghan government should also be proactive in providing property related assistance to certain segments of the population. Article 14 says that assistance programs should be provided to improve the lives of people in rural areas, and public lands should be distributed among "deserving citizens."

\section{Constitution of Afghanistan}

\section{Article 14}

1. The state shall design and implement within its financial resources effective programs for development of agriculture and animal husbandry, improving the economic, social and living conditions of farmers, herders, settlement and living conditions of nomads.

Commentary: The Constitution states that the government should aspire to finance programs that improve the lives of those living in rural areas who work closely with land and animals. This segment of the Constitution is not strict law because it describes programs that may only be carried out if sufficient funding is available. Therefore, the assistance described in this section may only be awarded when the government has sufficient resources.

2. The state adopts necessary measures for housing and distribution of public estates to deserving citizens within its financial resources and the law.

Commentary: When the state has the resources, it should also provide land and housing to people who merit such a grant from the government. This provision requires that the government have 
sufficient resources to carry out such distribution and that the government makes the distribution to deserving citizens. The Constitution, however, does not elaborate as to what might make someone a deserving citizen. If it were up to you, what characteristics or qualities would you look at to determine whether someone is a deserving citizen?

Article 14 demonstrates that the government is not only supposed to guarantee property ownership rights under Article 40, but also assist those who may not have property or are not able to use their property efficiently. Distributing property creates new property owners, and programs designed to assist rural property owners are intended to create a more productive population. Of course, the effects of these constitutional provisions are limited because they are contingent on the government having sufficient resources to carry them out. The effects of these provisions may also be limited by the government's ability and desire to carry forth these programs even if sufficient resources are available.

\section{Land Distribution Revisited}

We now return to the property distribution scheme described earlier in this chapter. ${ }^{17}$ There are approximately 30,000 Afghans who have now received land under this program. There are many, however, who cannot actually live on the land. People's jobs are typically located a long distance away from the land, and as previously mentioned, no water, electricity or other utilities are available. What are some steps the people living on the land should take to improve these conditions? Think about the community of other new landowners as well. If everyone has the same goal, what might they do to achieve that goal together? Is there an easy or straightforward resolution?

\section{B. Dispute Resolution}

Property law describes the scope of property acquisition, disposition, use, and exclusion. Present and future property owners may look to the law to help them avoid or resolve property disputes. By complying with the law, they are less likely to encounter legal problems. When a dispute arises and is brought to court, the role of the judge is to apply the law to help determine how the dispute should be resolved. In Afghanistan today, the vast majority of dispute resolution involves informal mechanisms and customary institutions in both rural and urban areas. As a result, the application of the law in practice may differ from the law as it is actually written.

Land administration is typically handled at the community level rather than by the national government for three reasons. First, many people doubt the government's capacity to handle land administration. There are various reasons for this, including a lack of governmental resources and low levels of trust between the people and the government. Second, the court system has a limited reach, especially in rural areas. For a court system to be effective it must be accessible and easy to use. Third, going through the official system can be much more costly than resolving a dispute at the local level.

\footnotetext{
${ }^{17}$ Afghanistan at the Crossroads, supra note 11.
} 
We now turn to a discussion on the mechanics of Afghan property law. In this discussion we examine several property law provisions of the civil code. We will also apply the civil code to real land disputes that have arisen in Afghanistan, and use comparative examples to think about how they should be resolved.

\section{Discussion Questions}

1. Should everyone in Afghanistan use the same dispute resolution mechanism?

2. Why might some people be better served by using a less formal or more formal mechanism?

3. Does the prevalence of informal resolution mechanisms help or hurt the national government? Is this an important consideration?

\section{Registration}

One of the key elements of a workable property law system is reliable system of registration. There are two prevalent types of property registration systems - titles systems and deeds systems. The following summarizes the key components of a system of titles, which is thought to be critical to economic development, followed by an explanation of deeds systems, which are prevalent in many developing countries. ${ }^{18}$ The following discussion highlights the differences and similarities between the two systems.

\section{Titles}

Most developed countries require a system of titles. A titles system is a registry of property ownership that serves as the primary evidence of ownership. In a title system, each piece of property is cataloged and its owner listed, minimizing the chance that competing claims will arise. A valid title is assumed to be evidence of ownership. There are three key principles to an effective titles system: the mirror principal, the curtain principal, and the assurance principle.

Under the mirror principle, a titles system should be like a mirror in that it reflects reality exactly. In other words, a title should state the accurate property owner. Under the curtain principle, a titles system should contain a definite answer about the title status of all property. Therefore, a titles system should be the only place a person needs to look for information on all property. Under the assurance principle, the government will pay for any damages incurred by errors in the registry. If there is a mistake and someone's property is not recorded correctly, the person will lose that property to the person who holds title to it, but the government will compensate them for that loss.

\section{Deeds}

\footnotetext{
${ }^{18}$ Klaus Deininger \& Gershon Feder, Land Registration, Governance, and Development: Evidence and Implications for Policy, 24 The World Bank Research Observer 233, 243-246 (2009).
} 
In Afghanistan, property has been recorded through a deeds system, largely in registries housed at the provincial level. A deeds registry is a public depository where documents providing evidence of land transactions are stored, numbered, dated, indexed, and archived. The key distinction between a titles system and a deeds system is that the government does not take responsibility for errors in a deeds system. As a result, deeds systems are less expensive for the government to maintain. Conversely, they may be more expensive for property owners because a valid ownership claim is not guaranteed under a deeds system, and potential buyers and creditors have to expend resources verifying that the seller or borrower has a valid ownership claim.

Recording of deeds in the registry gives public notice of a transaction. Thus registered deeds may take precedence over unregistered ones. Recording a deed, however, does not guarantee the validity of the underlying transaction. With the advent of digitized recordkeeping, however, titles systems and deed systems are becoming increasingly similar. While the difference is still that the government will only compensate for errors with titles systems, there are far fewer errors overall when records are maintained digitally. Thus deeds systems are becoming increasingly less costly and thus more easily utilized by the parties to a property transaction.

\section{A Successful Deeds Registry in South Africa ${ }^{19}$}

South Africa has one of the most successful deeds registries in the world. While most developed and developing countries opt for a titles system where the registry itself is evidence of ownership, South Africa has maintained its deeds system with great success. In a deeds system the documents are evidence of ownership, but the registry does not validate the underlying transaction represented by the documents. The South African deeds registry has been successful largely because the government has required detailed recordkeeping over a very long period of time. The records are so good that the South African deeds registry essentially guarantees title. When the practice of apartheid came to an end in the early 1990s, and people sought to reclaim lost land, the deeds registry was seen as an asset to this process. Apartheid stripped many South Africans of their land. Because detailed records were maintained for so long, the system was thought to benefit those attempting to reclaim lost property.

\section{Property Registration in Afghanistan ${ }^{20}$}

In Afghanistan, title deeds to property are stored together with other types of legal documents in regional archives called Makhzans. These Makhzans have been left in great disrepair in many instances, with the documents damaged or inaccessible to judges. Documents are stored in groups of one hundred in record books called Kundas, however, over the years many Kundas were destroyed and torn apart. Over the last several years, the Makhzans have

\footnotetext{
${ }^{19}$ H. M. Feinberg, South Africa and Land Ownership: What's in a Deed?, 22 History in Africa 439 (1995), available at http://www.jstor.org/stable/3171925.

${ }^{20}$ For more information about this restoration program read Restoring Legal Documentation in Afghan Registration Courts: A Report on the Makhzan Rehabilitation Program, USAID, Feb., 2007, available at www.afghanland.org/.../17-registration-courts-makzhans-in-afghanistan-usaid-ltera.
} 
been surveyed, cleaned and organized, and the records that are salvageable are currently being digitized and stored on electronic databases.

\section{Proving Property Ownership in Afghanistan}

Article 4 of the Law on Land Management describes the types of legal documents that establish property ownership in Afghanistan. Most often, valid ownership does not come into question unless there is a property dispute. There are several different types of documents that are deemed valid by Afghan courts to resolve property disputes. As you can see, even though Afghan law calls for registering the deed at the time of transfer, the law looks to less formal records to validate ownership claims:

\section{Law on Land Management}

\section{Article 4}

\section{The legal document issued by a court at the time of transfer}

Commentary: The document may be approved by a competent court, even if it was never registered if there is no other invalidating document. This document must also be registered in the tax book.

\section{A government decree and deed of purchase of a state property}

Commentary: Such a deed must not be superseded by any other documents and be registered in the tax book.

\section{Tax payment document}

Commentary: There may be no superseding deeds or decrees and the document must have been registered in the tax book.

\section{Water rights document}

Commentary: There may be no superseding document.

\section{Customary deed}

Commentary: Such a deed must be in the seller's possession and have been submitted to the relevant office before the year 1357 (Afghan calendar). In locations where there are no registration books, alternative methods of verification may be used.

\section{Title deed}

Commentary: This document must exist with respect to the land in question and be registered in the tax book. 


\section{Landownership document}

Commentary: This document must have been prepared by the relevant court and registered in the tax book.

As you can see, there are many different ways to prove property ownership. The law recognizes documents varying from a court-issued deed to a document showing a tax payment on a particular piece of property. The flexibility of the registration system is helpful because government infrastructure for property registration is weak, and there was no uniform way to register property in the past.

Afghanistan has also experienced several decades of conflict. Many people have been displaced and forced to leave their land over the years. Returnees are often eager to reclaim their land, yet in the period when they were away someone else may have occupied their land. Given Afghanistan's history of conflict and displacement, do you think the law goes far enough to help people validate their ownership claims? What else might the law take into account to verify ownership? Why would it be beneficial to take extra steps to verify ownership? Why not?

The following case study examines a dispute in which two people each believed that a piece of land was rightfully theirs. One owner fled Afghanistan and planned to return to reclaim the land, and the other owner stayed and thought the land belonged to him. When the prior owner returned, he demanded that the property be returned to him. As you read the following case, think about different considerations that should influence the result.

\section{Case Study: Land Appropriation in Kunduz}

A man named Yama inherited a piece of property from his father. His father had received the land from the government during the noqileen resettlement. Yama was a farmer who lived on and worked the land. Yama fled to Pakistan several decades ago because of the Soviet occupation. He had a government decree stating that the land was his.

After Yama left, a man named Haroon began to farm the land. Haroon thought the land was his. Haroon claimed that his father had given Yama's father a loan to purchase the land from the government, which Yama's father had agreed to repay. Haroon presented a hojatkhat (loan agreement) which is an informal document. Haroon argued that because Yama's father had not repaid the loan, the land belonged to him.

The Primary Court heard the dispute between the two men. Each of the men presented witnesses. Yama's witnesses said there was no loan agreement between the two men. Haroon's

\footnotetext{
${ }^{21}$ All case studies are based on actual case studies conducted by Colin Deschamps \& Alan Roe in Land Conflict in Afghanistan: Building Capacity to Address Vulnerability, Afghanistan Research and Evaluation Unit Issues Paper Series (2009), available at $\mathrm{http}$ ://www.areu.org.af/EditionDetails.aspx? EditionId=212\&ContentId=7\&ParentId=7. Many of the case facts and results have been modified.
} 
witnesses said that they heard that there was a loan agreement between the two men. If you were the judge in this case, how would you rule? What evidence would you consider?

Actual result: The judge in this case ruled in favor of Yama because he had better property documentation. That was not the end of the dispute though. Haroon appealed the case to Baghlan Appeals Court, where Yama feared Haroon would have an unfair advantage through a family connection. Thus Yama agreed to participate in a jirga. The result was that Yama would keep the property, but pay Haroon the 100,000 afghanis that his father had owed Haroon's father.

\section{Discussion Questions}

1. What kind of registration document did Yama have? What about Haroon? Which one seems strongest to you? Why? How do these documents compare to the ones listed in the Law on Land Management?

2. Notice that Yama chose to use an informal dispute resolution mechanism because he was worried about corruption in the formal system. What changes could be made to prevent this kind of corruption?

3. Do you think the final outcome of this case is fair? Why or why not?

\section{Transfer of Property}

Property is transferred between owners in two basic ways. First, property may be given to a new owner either through inheritance or as a gift. Second, the property may be transferred from one owner who is selling the property to a new owner who purchases the property.

\section{Inheritance}

Property is transferred through inheritance when the former owner passes away, and the ownership claim passes along to his or her heirs.

\section{Civil Code of Afghanistan}

\section{Article 1993}

Property left behind by the deceased shall be transferred to their heirs.

An heir is typically the spouse or the children of the former owner. Inheritance laws tell us who the new owners should be, and how much of an ownership claim over a particular piece of property they should get. This section will briefly cover several basic elements of inheritance law, which is found in the Civil Code of Afghanistan.

\section{Civil Code of Afghanistan}




\section{Article 2091}

Each person receiving an inheritance has the right of obtaining it individually, except when it is not divisible.

\section{Article 2092}

Any division of property that is not otherwise divisible must receive the consent of all heirs.

\section{Article 2093}

Should the heirs fail to reach an agreement on how to divide the property, they must go before the court and pay all of the expenses.

The law requires that all parties to an inheritance consent before dividing up a piece of property. There are often many heirs to a particular piece of property such as a home or a piece of land. Yet all must consent before selling the property and dividing the profits between themselves. Keep these rules in mind as you read the following case.

\section{Case Study: Inheritance Dispute in Herat ${ }^{22}$}

A woman named Sultana lived in Herat with her family, where her father owned a piece of land. Sultana's family fled Afghanistan and moved to Iran in 1985 after the Soviet invasion. While Sultana's brothers and mother frequently traveled between Iran and Afghanistan throughout the years, Sultana did not. When her father passed away in 1998 Sultana, her eleven siblings, and her mother inherited her father's property in Afghanistan.

Soon after her father's death, Sultana's siblings and her mother returned to Afghanistan and divided up the inheritance between only those who were present. Sultana returned to Afghanistan in 2005 and asked her family for her portion of the inheritance. She was told that because she was not present at the time the inheritance was divided up, she would not receive anything. Sultana took her case to the Herat City Court, but she was told that because not all of the heirs were present her case could not be resolved. Finally, a shura was held with all of the heirs, along with community elders and leaders. If you were the judge in this case, would you award Sultana her portion of the inheritance? What factors would you consider in making this decision?

Actual result: In this case, when Sultana's family had divided up the inheritance, community elders had mistakenly signed off on the agreement. The elders did not realize that Sultana stood to inherit even though she was not present at the time of the division. Her family thought that the division was appropriate without realizing that a mistake had been made. The shura decided in Sultana's favor and awarded her an inheritance. One eighth of her father's property was paid to her mother, and the remaining amount was split between herself and her siblings, with each brother receiving twice as much as each sister in accordance with Islamic Law.

\footnotetext{
${ }^{22}$ Deschamps \& Roe, supra note 21.
} 


\section{Discussion Questions}

1. In this case, Sultana's family and the village elders who signed off on the inheritance were unaware that Sultana was owed a share. What are some ways that simple confusion about the law may be avoided?

2. Why did Sultana and her family decided to use an informal dispute resolution mechanism rather than a formal one? Can you think of more reasons why she may have chosen this option?

3. Can you envision a case where Sultana would not be awarded an inheritance? What could lead to such a result?

\section{Sales and Purchases}

Property is also transferred when the owner of a piece of property decides to sell it to an interested buyer. The process for selling property is straightforward under the law. Nonetheless, keep in mind that buyers bear the additional burden of ensuring that the property they purchase actually belongs to person selling them the property, and that no debts are owed on the property.

The Property Dealers Law $^{23}$ regulates property transfers. The law requires that sales and purchases be made through officially registered dealers. These dealers must be Afghan citizens of good character with a high school diploma or equivalent. They must also publicize the sale to notify any party who may have a debt to collect on the property before it is sold.

Before property owners are able to sell their property, they must pay off all debts owed on the property. Once the property is free and clear, they may commence the transfer to the new owner. To complete the transfer, the buyer is required to register the property with the correct court and pay fees to the court.

\section{Civil Code of Afghanistan}

\section{Article 52}

An owner has the right to sell their property so long as they have a legal deed and have paid all outstanding debts on the land.

\section{Article 54}

Transfer of landed property takes place at the relevant court of the place where the property is situated, through the Land Management Department. The land must be registered in the principal land registration book and the book of taxes. This court will collect transferring fees.

Once the transfer process is complete, the property officially belongs to the new owner. The discussion will now turn to the rights of property owners with regard to land over which

\footnotetext{
${ }^{23}$ The Property Dealers Law was amended by Decree 76 in September, 2004.
} 
they have a valid claim of ownership. Before reading the next section, consider the discussion questions that follow.

\section{Discussion Questions}

1. Why does the government require that people go through licensed property dealers when buying and selling property?

2. Imagine that you are looking to buy a piece of property and that there are three equally good pieces of property to choose from. What aside from the land itself might influence your decision to buy a particular piece of property? Would you be hesitant to purchase a piece of property if the owner could not produce a valid ownership document? Why or why not?

\section{E. Use}

People purchase property with different intended uses. Under Article 1904, a property owner in Afghanistan may exercise possessory rights in accordance with the law. This means that a property owner may use his property in whichever way he wishes, but he may not violate the law simply because owns the property. For instance, a property owner may not rob someone because they are on his property; robbery is illegal everywhere in Afghanistan, even on private property. The following discussion will examine the limits of acceptable property use.

\section{Civil Code of Afghanistan}

\section{Article 1904}

The owner may exercise possessory rights in his property within the limits of the law.

As you read, consider the consequences of violating use laws. Under a functional property law system, if you use your property in a way that violates someone else's rights he may bring an action against you in court. What is the best way to resolve a dispute if a person lives in a remote area and reaching the nearest court requires a great deal of travel? What if there are problems with corruption in the local court? What if the judges are simply not very familiar with the law because of inadequate training? Think about alternative ways that people may use the laws to help resolve their disputes outside of the official court system. Often simply working together to reach an agreement leads to a more beneficial result than using the court system.

\section{Nuisance}

People must use their property in a way that does not harm others. When one property owner uses his property in a way that violates the rights of others without their consent, she may be subject to a nuisance action. Nuisance law typically protects people from harm that is intentional, non-physical, unreasonable, and substantially interferes with the use and enjoyment of the owner's land. 


\section{Civil Code of Afghanistan}

\section{Article 1905}

Where the right of another person is implicated, a property owner may not act in a way (with regard to their property) that would sustain loss on the right of the other property owner without their permission.

The authors of this textbook are not aware of any recent nuisance actions brought in Afghanistan. Perhaps courts are hesitant to allow recovery for nuisance actions, or perhaps people are simply hesitant to bring them. People and courts alike might not even be aware that such an action exists. Nuisance actions are likely resolved informally at the local level. One can imagine many situations when the way one person uses her property may adversely affect the rights of a neighboring property owner. Consider a situation in which a conservative family lives in Mazar-e-Sharif and does not approve of loud music. The family that lives next door to them often plays music loudly nearly every day, especially in the evenings. The conservative family members do not feel that they can fully enjoy their home when they can hear the music. Assume that there is nothing unlawful about the type of music being played. May the conservative family bring a nuisance action in court? Do they have a right to quiet property? How would your resolve a situation like this if you were a judge? How would you resolve a situation like this personally?

\section{Right to Light}

Also consider Article 1908, which states that a property owner may not fully block the light of others. Property owners, even when building within the limits of their own property, may not build a structure that blocks another property owner's view. This offense is so serious that the builder must mitigate the damage or have the structure demolished. Imagine that you are planning to build a house that will block light flowing to your neighbor's home. Would you go ahead with the project after finding out about this rule? Would you stop the project from going forward? Is there another solution? What kind of agreement might you work out with your neighbor?

\section{Civil Code of Afghanistan}

\section{Article 1908}

Full blockage of light from residence shall be considered gross damage; no one may build a construction that closes the window of the neighboring residence and causes full blockage of light to it. In case of construction of such a building the neighbor may demand, when possible, to eliminate damage, and when impossible, the demolition of the construction to eliminate damage.

\section{Contract}

A property owner may wish to enter a contract with another person relating to their land or home. 


\section{Civil Code of Afghanistan}

\section{Article 534}

Contracting is permissible except when the law provides otherwise.

There are many different reasons that a property owner might enter into a contract. A property owner might want to build on his land, have some work done on his home, or hire someone to take care of his home while he is away. While these are contracts for services, property owners may also contract around the law. In many cases the law sets a default standard to regulate the conduct between two or more parties, unless they agree to conduct themselves differently. For instance, in the prior Right to Light example, a property owner might enter into a contract with her neighbor. She may offer to pay a certain amount of money in exchange for the right to block her neighbor's view. If her neighbor ever takes her to court, she will be able to present the contract. Likewise, if she fails to pay the promised amount, her neighbor may take her to court and present the contract to the judge. Contracts may also be enforced under informal legal systems.

\section{Civil Code of Afghanistan}

\section{Article 551}

A contract must be entered into with the consent of the contractee.

Contracts must be entered into consensually. This means that the person agreeing to contract must be in total agreement without being coerced or intimidated. When someone is coerced or intimidated into entering a contract, they are not entering that contract freely by considering the potential benefits and consequences of the contract objectively. Instead, they are entering a contract solely to avoid a negative consequence that is unrelated to the terms of the contract. Consider the following examples and decide whether the contract is valid:

\section{Contract Hypotheticals}

1. Asa has a small plot of land in a large city and wants to build an addition to his home that will extend it almost one meter into his neighbor's land. He approaches his neighbor and offers to compensate her for the lost land. She is not happy about the addition, but is direly in need of extra income so she enters into a contract with Asa allowing him to extend his home. Is this a valid contract?

2. Consider the same example as above, except that now Asa does not tell his neighbor about the extension. Asa's neighbor does not know how to read and Asa is aware of this, so he tells her that a construction crew will be working near her property and he wants her to be aware that it will be noisy. He offers to compensate her for the noise so long as she signs an agreement with him. She does not know that the agreement is a contract in which she agrees to allow him to build on her land. Is this a valid contract? 
The first contract is valid, while the second contract is invalid. In the first scenario Asa fully discloses the incursions that he intends to make on his neighbor's property. Though she is unhappy about the incursions, she prefers to be compensated over denying Asa the right to build on her land. Because she consented to the agreement, it is lawful. In the second scenario Asa's neighbor is not told about the incursions that Asa plans to make on to her property. It does not matter that she is compensated for the incursions. Under a valid contract Asa's neighbor would have the opportunity to decide whether the compensation was sufficient in light of the land that she was about to lose. Because she was denied this opportunity, the contract is invalid.

\section{Water Rights}

Water rights are an important component of property ownership, especially on agricultural land where water may be used for irrigation. We will first discuss water rights in general, and then water that flows through property.

\section{Civil Code of Afghanistan}

\section{Article 1916}

(1) The water right of the land goes with the land.

(2) Sales, donation, and leasing of the water right the land when exceeds the need of the owner of the land is not permissible except for irrigation purposes. (sic)

(3) Other provisions related to water rights and irrigation of the land which are not anticipated in this [] shall be governed by special law.

.

Article 1916 states that water rights run with the land and also prohibits transferring these rights for all purposes other than irrigation. This means that a property owner may lease, give, or sell the right to use water flowing from her land to a third party, such as a neighboring property owner who needs the water for irrigation purposes. If that property owner purchases the water right, they have total control over it and are not required to give it back to the original holder of the water right at any time. Furthermore, water rights may be transferred upon the owners passing to his or her heirs.

\section{Civil Code of Afghanistan}

\section{Article 1915}

Water rights for the purpose of irrigation may be transferred through inheritance or bequeathing.

A different set of laws operates on water that flows through private land. When a property owner makes an agreement to pass water through his land to another property owner, he may no longer act to prevent the passage of water through his land. To do so would be to breach the contract he entered into with the more distant property owner. Likewise, a property owner who wants water for irrigation is not entitled to have water pass from a neighboring property on to his land. Nonetheless, a landlord receiving "just compensation" under Article 17 is obligated to allow water to pass through his land 


\section{Civil Code of Afghanistan}

\section{Article 1912}

The owner of the land that is irrigated through irrigating equipment or canal, when not having the right to pass water through other's land, may not force the owner of the said land to allow passage of water.

\section{Article 1913}

Whenever a person has the right to pass water through other's land, the owner of the land may not prevent the passage of water through his land.

\section{Article 1917}

The owner of land is obligated to allow sufficient water to flow through his land for irrigation of lands more distant from the source of water as well as allowing the flow of excess water to the nearest canal provided he receives just compensation.

The right to use water flowing from a public canal is distributed in proportion to the land requiring water for irrigation. The Civil Code does not state whether water rights emanating from common waters are transferable. What the law does tell us is under the default rule, a single property owner does not have unlimited access to public waters.

\section{Civil Code of Afghanistan}

\section{Article 1911}

With due consideration to avoiding damage to the public, the right to use the water of public canal shall be determined and distributed in proportion to the land requiring irrigation.

Property owners must be cognizant of how they use water on their own property. For instance, a property owner is permitted to irrigate his land in accordance with normal irrigation practice. Imagine a situation where the owner of a piece of agricultural land waters his crops, and as a result some water flows into his neighbors land. Imagine now that the neighbor's crops die. Should the property owner be held responsible for the death of the crops and be required to compensate his neighbor?

\section{Civil Code of Afghanistan}

\section{Article 1914}

A person who irrigates his land in normal way, to the extent that the land can take it, and as a result water flows into the land of another and destroys his crops, he shall not be required to pay recompense. In case he irrigates his land in an abnormal manner, and another person sustains damage as a result, he shall compensate.

The answer depends on how the property owner irrigated his crops. Under Article 1914, if the property owner used normal irrigation techniques and his own crops were able to survive, then he will probably not have to compensate his neighbor for the loss of his crops. If his 
irrigation techniques were abnormal, however, and his neighbor sustained damage as a result, the property owner will likely have to compensate his neighbor.

While Afghan laws regarding water rights are largely written with individual property owners in mind, people rarely access water purely individually. Communities by and large negotiate deals for water and work together to create mechanisms to distribute water. Thus tensions may be created depending on the sizes of different communities seeking access to water, and even the ethnicities of those communities if two or more communities of different ethnicities are seeking access to water from the same source. Consider these two factors-size disparity and difference in ethnicity - as you consider the following case study. Think about what role the government may play, if any, in helping communities with less power gain access to water.

\section{Case Study: Water Allocation in Parwan $^{24}$}

Three villages complained that twenty villages located upstream were limiting their access to water for irrigation and drinking. The upstream villages had built a dam in the public canal so that water no longer flowed downstream. When villagers from downstream complained, the upstream villagers demanded payment for access to water. An additional point of contention was that the three villages located downstream were composed of villagers of a different ethnicity than the villages located upstream. A jirga was convened and the upstream villages decided to allow the flow of water to the downstream villages.

The conflict continued because commanders from the upstream villages did not obey the agreement reached at the jirga and again stopped the flow of water. Village elders and other community leaders could not convince the commanders to restart the flow of water. As a result of the water shortage, several people from the downstream villages died, and several hundred more were forced to relocate, mostly to Kabul. What would you do to get water to the downstream village? Would you try to work out an agreement between the villages? Would you go to court to get a judgment against the upstream villages?

Actual Resolution: The villages worked out an informal water sharing agreement. None of the villages attempted to utilize the formal judicial system. Both sets of villages were concerned with the enforcement of the agreement. Those located downstream wanted to make sure that the upstream villages did not shut off the flow of water. Those located upstream wanted to make sure they would still have access to sufficient water.

\section{Discussion Questions}

1. Do you see any advantages to using the formal judicial system in this case? If so, what are they?

${ }^{24}$ Deschamps \& Roe, supra note 21. 
2. How do you think the villages will enforce their agreement? What are some techniques they can use?

3. Based on the laws on water rights that you read at the beginning of this section, how should this case have been resolved? Would it come out differently if the canal was private, only provided water for irrigation, and the downstream villages had an additional source of drinking water?

\section{Mineral Rights}

While a whole textbook could easily be dedicated to the Law on Minerals alone, we will touch briefly on the subject. Think about a property owner who owns a large tract of non-arable land. Non-arable land is land that cannot sustain growth, such as a rocky hillside. What is the result if the property owner discovers a mineral deposit on her land? In light of recent data showing a wealth of minerals in Afghanistan, this question does not require a large stretch of the imagination. ${ }^{25}$ Yet the answer to this question is simple: the property owner may not do anything, because all minerals located above and below ground belong to the State. The property owner will receive a reward, but will lose her property to the state.

\section{Civil Code of Afghanistan}

\section{Article 1988}

Whenever mine, treasure, or ancient relics are found in privately owned land, they shall belong to the state. The owner shall receive [a] reward in addition to expropriation of the land in accordance with the law.

According to Article 1988, an owner of property that contains minerals will receive a reward in addition to compensation for expropriation. Land is expropriated in accordance with the Law on Land Expropriation. ${ }^{26}$ The law states that only part of a person's land will be expropriated, unless this would make exploitation more challenging or exploitation activities would damage the un-expropriated land. In these cases, all of the land is expropriated.

Under the Law on Land Expropriation a five-member commission, including the property owner, determines the extent of the damages resulting from land expropriation. The property owner is compensated for the land itself, any buildings constructed upon the land, and the price of any fruit bearing trees or saplings on the land. The price of the land is determined by the Council of Ministers, though land obtained through a government distribution program from 1978 to 1992 is not compensated for. The price of the buildings is determined by the committee of Kabul Municipality in accordance with the Unified Table for Valuation. The price of trees and saplings, if the owner decides to abandon them, is decided by the municipality and the Administration for Agriculture. While the law does not explicitly state how quickly a property

\footnotetext{
${ }^{25}$ James Risen, U.S. Identifies Vast Mineral Riches in Afghanistan, New York Times, available at http://www.nytimes.com/2010/06/14/world/asia/14minerals.html.

${ }^{26}$ As amended on October 8, 2000.
} 
owner must be compensated, ownership rights terminate three months before the expropriated property is needed so long as the owner has been justly compensated.

If a person wants to mine for minerals in Afghanistan he must be the holder of a mineral right and meet several requirements. ${ }^{27}$ Such a person must be over the age of eighteen and lawfully reside within Afghanistan. Entities that are lawfully entitled to operate within Afghanistan may also hold mineral rights. There are several restrictions prohibiting those with strong ties to the government, those who are bankrupt, those with criminal backgrounds, those who are mentally incompetent, and those who previously had their mineral rights revoked.

According to the Ministry of Mines, the mining law has been amended recently to make Afghanistan more appealing to foreign investors. ${ }^{28}$ To explore for and mine minerals, miners need two separate licenses. The exploration license allows the license holder to conduct mineral exploration work. The development license, likewise, allows the license holder to conduct mineral exploitation work. Whereas both of these licenses were to be obtained separately, under the revised law, a mineral rights holder may automatically convert an exploration license into a development license, so long as he fulfills his legal obligations.

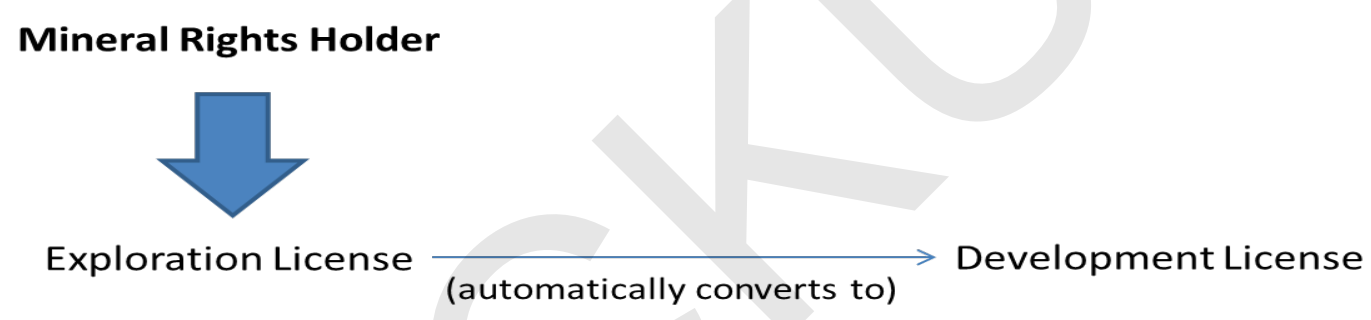

Takings

A taking is when the government prevents a piece of property from being used in a particular way. When the government takes property from a private party, it must typically compensate for that taking. There are various levels of takings ranging from condemnation to regulatory takings. We will consider condemnation first. In keeping with our discussion on minerals, when the government condemns and expropriates property from an owner for the purpose of exploitation, this is a taking. The owner may not exploit land containing minerals, nor may the owner act to prevent the exploitation of minerals, thus property containing minerals that will be exploited is taken by the state. Because this is an obvious taking, the Law on Land Management requires that the former property owner be compensated.

At the other end of the spectrum, the government may regulate the way in which a piece of property may be used; this is called a regulatory taking. In the case of a regulatory taking, the government prevents the owner from using the property in a certain way, even though it will cost the owner financially. If the government sees that the property owner is still using her property in

\footnotetext{
${ }^{27}$ Ministry of Mines Website, Frequently Asked Questions, http://mom.gov.af/?page=faq\&lang=en. ${ }^{28} I d$.
} 
a forbidden way, it may take further action against the property owner. To better understand regulatory takings, consider the following discussion on opium eradication.

\section{Opium Eradication in Afghanistan ${ }^{29}$}

In Afghanistan it is illegal to grow opium poppies for the purpose of producing heroin. Nonetheless, opium poppies have become a staple crop that is both financially lucrative and extremely common in some parts of Afghanistan. The law forbidding people to grow this crop for profit is a form of regulatory taking. The government ban on opium production might seriously reduce the value of a person's land. The policy behind the law, however, is that the public benefit from reducing opium production outweighs the benefit gained by individual property owners and opium producers. In the case of opium, the government sometimes goes a step further and enters people's land to eradicate the crop. Because this type of regulatory taking prevents property from being used unlawfully, the government does not compensate property owners for opium eradication. In turn, private property is preserved for use in lawful ways. In your opinion, is opium eradication an example of a regulatory taking, or is this more akin to condemnation? Why? What might the government do to effectively end opium production?

Takings are clearly permissible under Afghan law so long as owners are compensated. Thus condemnation is permissible so long as the government follows the Law on Land Expropriation. The legality of regulatory takings by the government is less clear, though Article 40 of the Constitution of Afghanistan makes clear that property may be used for any purpose within the bounds of the law. Thus, if a law is enacted forbidding a particular use, this would be deemed a regulatory taking. Such a regulatory taking would be completely within the bounds of the law.

\section{Adverse Possession}

Adverse possession is when a person takes control of a piece of land that she does not own and ultimately gains ownership rights. He may ultimately become the recognized property owner if he meets the requirements under the law of adverse possession. Because the law of Afghanistan does not allow private land to be adversely possessed, we will focus our discussion on adverse possession of government land.

Under Article 1991 of the Civil Code of Afghanistan, unowned arable land is the property of the state and may not be possessed without permission from the state. Arable land is land that is capable of sustaining growth-most often to grow crops or to use as grazing land. A landless person returning to Afghanistan may come across a piece of good farm land that is unowned, establish themselves there, and begin to work the land if he has government permission. Without permission, however, and lacking the requisite documentation, he will be subject to eviction at any time. Furthermore, even obtaining government permission will not enhance his prospects of eventually becoming the owner of the property.

\footnotetext{
${ }^{29}$ Jeremy Kelly, Taliban Happy as Police Smash Poppy Crop, The Australian, May 16, 2011, available at http://www.theaustralian.com.au/national-affairs/defence/taliban-happy-as-police-smash-poppy-crop/storye6frg8yo-1226056373738.
} 


\section{Civil Code of Afghanistan}

\section{Article 1991}

Unowned arable lands are the property of the state, possession thereof without the permission of the state, and in contravention of the provisions of the law, shall not be permitted.

In contrast, there is no dispute that unused government-owned non-arable land-land that cannot sustain growth-may be deemed the property of the person who takes possession of it in some circumstances, so long as she has the permission of the government and pays taxes on the land. These two laws may be distinguished on the basis that the Afghan government has a stronger interest in controlling the ownership of farmland, with its clear economic value, than non-arable land whose value may not be easily monetized. For an illustration of the adverse possession process and how the law operates in Afghanistan, see the diagram below.

\section{Civil Code of Afghanistan}

\section{Article 1992}

Uncultivated, non-usable land, when unowned, shall be deemed the property of the person who has taken possession of it with the permission of the government ...

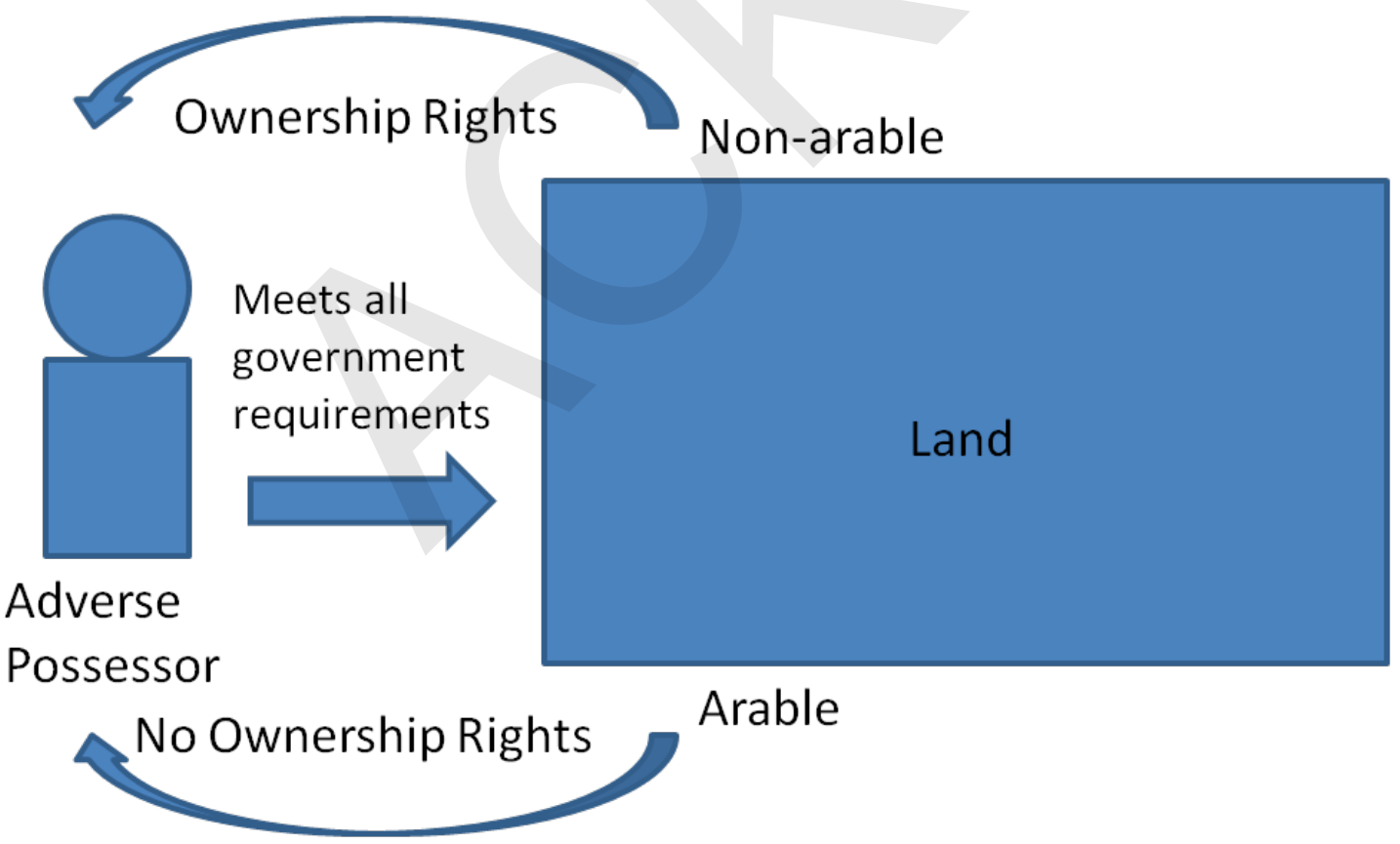

In some countries the law of adverse possession gives squatters the right to possess unused land belonging to private parties. Once the squatter has possessed the land for a sufficient period of time, he gains title to the land. This is not the case in Afghanistan, where people only have the ability to gain a valid claim of ownership from adversely possessing government owned land. Now consider a situation in which someone owns a piece of property and then leaves the country for 30 years. In the meantime a relative of the property owner sells the land using false 
documents, claiming that he is the owner. The new owner pays the full price for the land and begins to live there. Her family builds a home on the land and makes several more improvements over the years. 30 years later the property owner returns and demands that she return the land. Consider the following questions.

\section{Discussion Questions}

1. Consider the previous example. Is the new property owner an adverse possessor? Why or why not?

2. How should a dispute such as this be resolved? Who should bear the loss? If you were the judge in this case, what would influence your decision?

3. What if someone adversely possesses a piece of private land and the original owner never returns? Should the property become hers? How long should she have to wait? Why might adverse possession be beneficial in some cases? What if a distant relative of the original owner comes to claim the property? Does the relative have a valid claim?

\section{Restitution}

Many of the current property law disputes in Afghanistan stem from the large returnee population. Returnees are often in dire need of land or intent on validating their preexisting claims to land. The government of Afghanistan is aware of the obstacles faced by returnees under the law and has taken special measures to assist them. ${ }^{30}$ The Decree on Dignified Return of 2001 guaranteed a safe return and the right to establish residence and to recover property. A Special Property Disputes Court was established in 2002 for the specific purpose of assisting new returnees in resolving property disputes. Information about the effectiveness of either the decree or the special court is limited.

\section{F. Exclusion}

A property owner has the right to exclude others from her property. When a person enters private property without the permission of the owner, she unlawfully trespasses on that property. Trespass is an explicit violation of Article 40 of the Constitution of Afghanistan, which states that property must be free from invasion. This section will explain the limits of that control.

\section{$\underline{\text { Easements }}$}

People have a right to use property they do not own when they have an easement. An easement grants a person permission to use property in a particular way. The right of easement is the right to make use of the land of another, including public land, so long as it is not contrary to

\footnotetext{
${ }^{30}$ Yohannes Gebremedhin, Land Tenure and Administration in Rural Afghanistan: Legal Aspects, Afghanistan Capacity Building for Land Policy and Administration Reform Project Report 7, Sept., 2007.
} 
the use for which it was appointed. The right of easement can be acquired through a legal commitment or an inheritance.

\section{Civil Code of Afghanistan}

\section{Article 2340}

Easement is the right held by a person to make use of the land of another.

\section{Article 2341}

The right of easement can be held over the public property provided it is not contrary to the use of the said property for which it is appropriated.

\section{Article 2342}

Right of easement can be acquired by a legal commitment or by inheritance. The lapse of time does not cause the right of easement to be acquired except the right of passage.

An easement may not usually be acquired simply because a person consistently makes use of property he does not own without permission or repercussion. For instance, simply because a goat owner lets her goats graze on another property owner's land for five years in a row does not mean that the sixth year the property owner must still allow the goats to graze on his land. The property owner may tell her to graze her goats elsewhere and seek to resolve the matter through the legal system or informally if she does not comply.

The exception to this rule is that an easement may be acquired through the passage of time when the easement pertains to the right of passage. If someone has passed through property for a significant period of time, the owner of that property may not prevent his passage in the future in some cases. Consider the role of time as you read the following passage on nomadic people.

\section{Nomadic Rights ${ }^{31}$}

Over the past decade there has been some conflict in Afghanistan regarding the rights of nomadic groups, the most publicized regarding the Hezaras and the Kuchis. Rather than staying in one place all year, nomadic groups such as the Kuchis move around, often for the purpose of grazing their animals. There has been conflict between the Hezaras and Kuchis with regard to whether Kuchis should be allowed to graze their animals on Hezara land. Keep this in mind as you answer the following discussion questions. Also remember that these questions are difficult and still unresolved today. As such, it is not likely that there is only one right answer.

\footnotetext{
${ }^{31}$ For more information on one particular dispute on nomadic rights read Afghanistan: Threat of ethnic clashes over grazing land, Integrated Regional Information Networks (IRIN), April 7, 2008, available at http://www.unhcr.org/refworld/docid/47fcca351a.html.
} 


\section{Discussion Questions}

1. Imagine that you are a lawyer representing a group of nomadic Kuchis that have come in conflict with a small Hezara village. They pass through the village on a yearly basis, and always allow their animals to graze on the land. What arguments would you make to help show that the group's actions are lawful? Would it help you to know that the nomads only let their animals graze on public land? What if they have been passing through the land for more than fifty years?

2. Now imagine that you are a lawyer representing the Hezara villagers. What arguments would you make on their behalf to keep the nomadic group off of the land? What if every year the villagers have to replant their crops after the nomadic group passes through? What if the villagers were displaced from the land for thirty years and only returned a couple years ago?

3. Can you think of a solution that would satisfy the needs of both groups?

There are some cases when easements to pass through private property are mandated under Afghan law. A property owner has a civil law easement to pass through his neighbor's property to reach the nearest public thoroughfare. The diagram following the relevant Civil Code provision illustrates an easement in the form of a passageway and demonstrates why these types of easements benefit property owners.

\section{Civil Code of Afghanistan}

\section{Article 1919}

The owner of the land not linked with public way, or the path leading to it is insufficient and difficult so that building of sufficient way is not possible without huge expenses and grave difficulty, may, against just compensation ... use the neighboring land for the purpose . . . at a place where passage is rendered possible with the least damage.

\section{Article 1919 Easement}

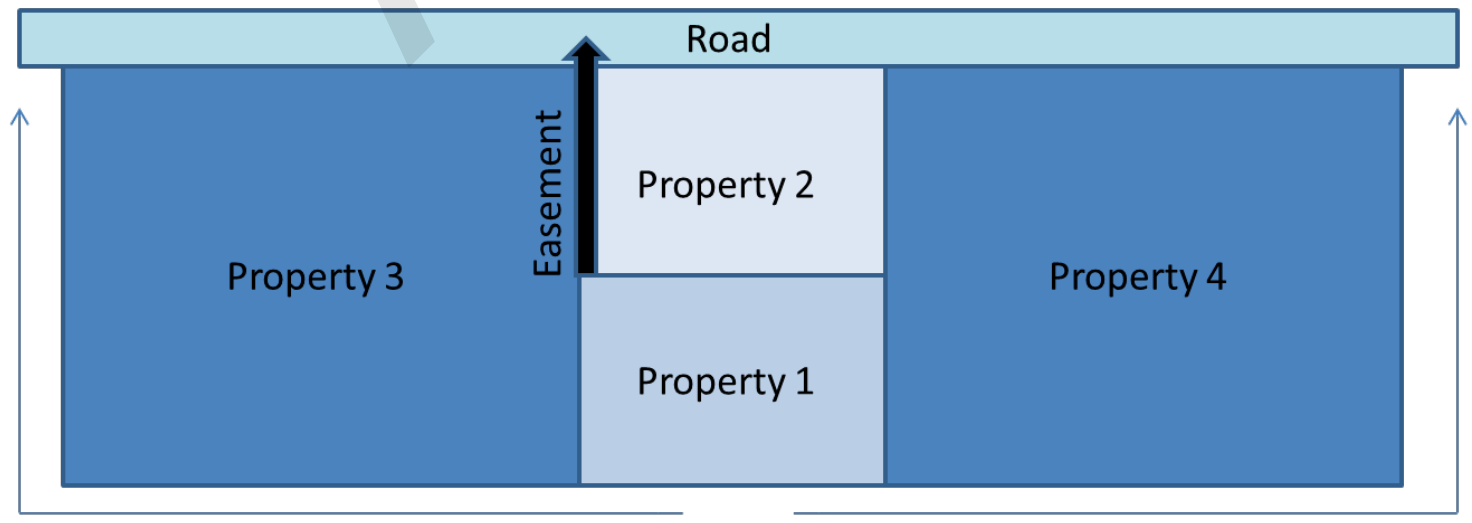

Without an easement for passage, the owner of Property 1 would have to travel a very long distance to reach the road. 
Nonetheless, simply because a person has an easement to use the land of another in some way does not mean that the owner of that land must maintain the easement. In the absence of an agreement stating otherwise, the holder of an easement bears the cost of that easement. In the case of an easement to pass through the land of another, the person passing through would be required to clear a path for themselves. It is not the property owner's responsibility to ensure that a clear passage is available.

\section{Civil Code of Afghanistan}

\section{Article 2357}

The expenses of actions considered necessary for exercising the right of easement or for protection of such right shall be borne by the holder of the right of easement unless a condition is made to the contrary. If the said actions are useful for the owner of the land of easer, the obligations for protection of the right of easement may be fulfilled proportionate to the profit which each one may get from it.

\section{CONCLUSION}

This chapter has endeavored to provide an overview of the property law of Afghanistan. We began with a discussion on why property law is important in the first place, focusing on the relationship between functional systems of property law and economic development. This chapter then discussed the mechanics of the property law of Afghanistan, focusing on property registration, property acquisition and disposition in the section on transfers of ownership, followed by sections on use and exclusion. As noted, when thinking about property disputes, consider formal routes for resolution as well as informal dispute resolution mechanisms. 


\section{GLOSSARY}

Acquisition In property law this describes purchasing, inheriting, or receiving a piece of property.

Breach When someone does not follow through with something, such as an agreement; i.e. breach of contract.

Deed A legal instrument containing a property transfer.

Disposition In property law this describes selling, gifting, or bequeathing a piece of property.

Exclusion The segment of property law regulating the extent to which a property owner may keep others off of his or her land.

Expropriate When a property owner's land is taken from them without his or her consent.

Title All of the elements constituting legal ownership.

Use The segment of property law regulating what a property owner may lawfully do with his or her property. 


\section{CHAPTER 5: COMMERCIAL LAW}

\section{INTRODUCTION}

Rajibullah has been living outside Kabul for the past four years managing a small brick factory. The bricks that the factory produces are of low quality, but he is unable to improve the quality because the owner of the factory refuses to invest in new equipment. After researching the market and noting the amount of construction taking place in and around Kabul, Rajibullah thinks that if he were to open his own factory with better equipment, he could make higher quality bricks and sell those bricks for a profit. Unfortunately, the brick business does not pay workers very well, and Rajibullah does not have the money needed to build his own factory.

How can Rajibullah put his idea into action? He could try to ask family and friends for money since those who know him consider him to be intelligent and trustworthy, but he comes from a poor family that does not have enough money to fund such an enterprise. He could ask a bank for a loan, but how would he be able to assure the bank that he could repay the money? Perhaps he could find a rich partner or an investor willing to take a chance on this business in exchange for a share of the profits.

No matter how Rajibullah seeks to raise money, there will be risks to his business that may make a lender reluctant to help Rajibullah start his business. The business might not be profitable because competitors decide to sell a similar product at a lower price, causing investors to lose their investment; Rajibullah's bricks could sell well, but he might have trouble collecting payment from his customers; or once a profit has been made Rajibullah could claim that he should receive a larger share of the profits because the business was his idea. These and any number of other reasons could make providing money for Rajibullah's business a risky venture for investors.

Commercial law can reduce many of the risks investors face when funding such a business. The law provides information about investors' legal rights. Contract law and the laws that structure business corporations govern who owns the assets and profits of a business and bankruptcy law governs how the assets will be distributed if the company becomes insolvent. Contracts with suppliers of materials and customers may provide additional assurance that Rajibullah's business is going to be able to produce and sell bricks for a profit. The combination of these types of legal structures may provide investors with enough assurances that they are willing to take a chance on Rajibullah's business.

Commercial law also must also balance the need to protect investors, lenders, and contracting parties with the need to provide incentives for entrepreneurs to go into business. Just as investors want assurances that they will receive their fair share of the profits from that business, entrepreneurs are more willing to try to build a new business if they know they are not risking everything on a single venture. If Rajibullah knows he will be personally required to pay back investors and lenders if his business fails, he is probably much less likely to try to start the business in the first place. If the market needs bricks to help fuel the growth of construction and the economy in general, then it may be desirable for the law to provide some limit to Rajibullah's 
personal exposure to the risks of his business. Tensions such as this will be evident in almost every aspect of commercial law.

As you read this chapter, there are several important questions that you should consider. What areas of law are most important to the conduct of business in Afghanistan? How do these areas of law change the way that people deal with risk and hopefully reduce the level of risk they must accept for an expected profit? Is certainty always desirable? What are the tradeoffs people must accept when setting up a system of commercial law? How is the way people and businesses rely on the legal system to protect their interests in commercial transactions changing?

The way in which legal concepts and laws are formed and implemented can affect the development of the economy and the success of the businesses and the people who own or are employed by those businesses. We will explore the reasons that laws are created and the functions that each area of business-related law serves in society. We will address contract law, agency theory, laws related to banking and finance, laws dealing with the establishment and operation of businesses, government entities that provide a means for the enforcement of commercial law, and taxation and customs. Without a doubt, creating and successfully implementing effective laws that can provide an efficient and reliable framework for the conduct of commercial enterprise in each of these areas is vital to Afghanistan's future. However, determining what laws will be most effective at achieving economic prosperity is not easy.

Afghanistan's economy is developing rapidly. Businesses transactions are becoming increasingly complex and require a wider variety of laws to regulate them. The growth of business increasingly requires people to deal with other people outside of their families, local communities, and social groups. This has created a greater need for a formal system of laws to structure these new relationships between strangers. No longer can community ties guarantee that a promise will be kept. Today, laws serve this function.

As new commercial laws are developed, however, it is important to examine the purpose of a given law and if it can be implemented effectively. In many ways, Afghanistan's commercial legal system is still in the early stages of a rebuilding process. Several new laws relevant to business have been enacted since the adoption of the 2004 Constitution and, as of 2009 , several other laws were in the process of being drafted. However, implementation of some of the new laws has been limited, and courts and government agencies frequently still rely on customary practices or laws that were drafted fifty years ago and that have not been updated. In many cases, people continue to resolve their commercial disputes through informal methods because seeking fair and reliable enforcement of commercial laws through the formal system continues to be a challenge.

Therefore, in addition to providing an overview of formal commercial law in Afghanistan as it currently exists, this chapter will identify the function that effective commercial law should serve for the economy and society. The chapter will also attempt to identify the ways in which current commercial practices diverge from the way commercial practices might be conducted if formal commercial law as it has been adopted was fully implemented. By studying the concepts of this chapter, you will gain the knowledge necessary to identify areas in which Afghanistan can 
strengthen its commercial law, thereby creating an environment where the economy of Afghanistan can grow and bring prosperity to the people of Afghanistan.

\section{The Economic Purpose of Commercial Law}

What is the goal of commercial law? Is regulation necessary to create conditions for economic growth? What is the best way to balance the interests of different actors in the market? The economy of Afghanistan has been severely affected by years of war and political instability. In order to fully recover from these challenges and reach a level of economic activity that could be expected of a country with Afghanistan's resources, Afghanistan is in the process of shifting from a low-productivity informal economy to an economy that is formalized and efficient. Currently, the economy of Afghanistan is strikingly informal in nature, meaning that most business activities are not registered with the government and no taxes are paid on most transactions. For example, up to 80 percent of transactions in the housing market in Kabul are informal.

Imagine a person who would like to invest in a business in Afghanistan, perhaps by developing a new office building. This person is much less likely to invest that money if there is a substantial risk that there will be no legal protection for that investment. Without a formal legal system that is available to all people, the investor might have no way to protect himself from a building contractor who agrees to build the office building but fails to complete the project after taking the investor's money. In an informal system, some people might be able to protect their investment, but others cannot. For instance, the investor might have connections to powerful people who could help force the contractor to fulfill his obligations, or they might control other businesses or have friends who would no longer hire the contractor in the future if he did not complete the project. On the other hand, the contractor might have more connections or friends who can intimidate the investor into paying more for the project than the agreed upon price. In situations like this, most potential investors do not have the means to protect their investments informally.

But even without corruption and other crimes, there may still be a great deal of uncertainty involved in starting and running a business. What share of the profits will an investor receive from the company that he or she helped to fund? Was a contract between a supplier and his customer for a particular quality of cement, or can the supplier provide any grade of cement the supplier chooses? Do parties to a commercial transaction have rights other than those explicitly outlined in their contract? When a business closes, who receives the remaining assets of that business? These are the types of questions that a formalized system of commercial law is intended to answer, ideally in a clear and predictable way.

By formalizing the economy, ensuring that businesses are in compliance with legal requirements, and creating methods of legal enforcement that are available to everyone, Afghanistan can reduce the risk of doing business and thereby increase the levels of private investment in the country. A formalized economy also creates conditions that "promote exports, ensure the safety of goods in the domestic market, and ensure adequate levels of competition necessary for the equitable operation of the marketplace" (Arsala 2007). Such conditions allow a country to achieve higher economic growth rates and greater prosperity. 


\section{CONTRACT LAW}

Contracts are the basis for almost all commercial transactions. When people enter into commercial transactions, contracts are used to determine exactly what each party expects to receive from the bargain. When contract law is clearly elaborated and consistently applied, all parties to the transaction know what their rights under the contract are, and the parties also know that their rights under the contract will be enforced in a relatively predictable way. Without contract law, parties to a transaction cannot be assured that they will receive the benefits of the agreement. It might be unclear if a valid agreement has even been struck, or the parties may have different interpretations of the actual terms of the agreement even if they can agree that they made an agreement.

For instance, you and I might agree that I will sell you all the wheat harvested from my farm for a fixed price. If bad weather destroys almost all the wheat before it is harvested, do we still have a contract? Must you still pay the agreed upon price even though you are now only receiving a small portion of what you expected? Such doubt tends to make parties less willing to enter into transactions, particularly long-term transactions, and tends to limit economic opportunities for all. Contract law reduces this doubt by creating rules that parties to a contract can use to answer these questions.

As of 2009, Afghanistan effectively has no formally adopted, clearly elaborated, and consistently applied contract law. However, there are several sources of contract law that have been used in the past or are currently being used even though they were not adopted under the current constitutional system. The government is in the process of drafting a law of contracts that is expected to be adopted in the coming years. The adoption of a unified formal law on contracts is an important step to creating productive and efficient social and economic conditions. Formal contract laws bring greater certainty to personal interactions and business transactions.

Although the new law of contracts is still being drafted and has not yet been adopted, this section provides an overview of some sources and historical authorities on contract law in Afghanistan. This section also provides several key contract law concepts that are found in the legal systems of other countries. Afghanistan has the potential to experience substantial economic growth from natural resources and international trade. Therefore, it is important to understand contract law in other countries as well since many cross-border transaction agreements will be drafted according to foreign contract law.

For that reason, although Afghanistan is a civil law country, many of the contract law principles covered in this chapter will have their origins in common law. The common law of contracts is a form that is used by many countries including the United Kingdom, Pakistan, India, and the United States. As discussed earlier, common law differs from civil law used in Afghanistan and many other countries. However, many of the concepts of the common law of contracts that we will deal with in this section also may be applied to contract law in the civil context. 


\section{The Definition of a Contract and the Purpose of Contract Law}

A contract is an agreement between parties that has a legal means of enforcement. Generally, contracts are formed when parties exchange promises to take (or not take) certain actions. A party who does not fulfill his or her promise is said to have breached the contract. When a party breaches a contract, he or she is required to compensate the other party or parties to the contract for the damages caused by their breach. Normally, the breaching party is required to compensate the other parties with money, but sometimes a court may require the breaching party to perform some action to alleviate the damages to the other party or parties, which is commonly referred to as an equitable remedy.

The ultimate goal of contract law is to provide the damaged party with the benefits they should have received had the promises been fulfilled. Therefore, when a court or other authority assesses damages, the damages are assessed with the intent of compensating the damaged party for the losses he or she has sustained as a result of the breach and are not intended to penalize the breaching party for wrongdoing. Compared to criminal law, there is less focus on wrongdoing and more focus on fulfilling whatever promises were agreed to by the parties. Frequently the parties will agree to an alternative arrangement when one party breaches a contract since actual enforcement of the contract could take time and might be expensive.

\section{Discussion Questions}

1. How does a contract differ from other promises?

2. Why is it important to create an established and consistently applied contract law in Afghanistan?

\section{A. Central Concepts of Contract Law}

Contract law in Afghanistan provides a variety of contracting principles and rules, including many that are common in contract law around the world. We will now explore some of the most common and central concepts of contract law in greater depth.

When contract law creates rules for the formation of a contract, a consistent interpretation of the terms of the contract, and a framework for how contract rights and obligations can be transferred between parties, business transactions can be completed with greater certainty. This also makes it easier for lawyers to use the rules to create an agreement that more closely mirrors the intentions of the contracting parties. 


\section{B. Contract Formation}

\section{Requirements for a Valid Contract}

In order for a promise to constitute a binding contract between parties, four elements are generally required:

1. mutual consent of the parties,

2. consideration,

3. responsible parties, and

4. an enforceable subject of the contract.

Mutual consent of the parties means that one party offers to enter into an agreement, and the other party accepts the terms of the agreement that the offering party has proposed. Often the accepting party will do so formally, either in writing or by saying, "I accept." However, sometimes consent may be inferred through the actions of the parties.

For instance, if I offer to sell you my car for 2000 Afghanis and you give me 2000 Afghanis, take the keys from me, get in the car, and drive away, it would seem that you accepted my offer even if you did not explicitly say so or do so in writing. But perhaps you meant you were just going to take the car for a drive to determine if you wanted to buy it and you were letting me hold the money to guarantee that you would not steal the car. In some cases, contract law may require that the parties make their agreement in writing when the value of the transaction is high or the contract is for certain purposes. This decreases the likelihood that there will be a misunderstanding about the intent of each party.

Contracts also require consideration. Consideration means no party should enter into a binding agreement from which they will receive nothing. When one party gives something to another party without the expectation of receiving anything in return, he or she is giving a gift, not entering into a contract. Under most circumstances, one person's promise to give a gift to another person is not enforceable as a contract.

Parties to a contract must have capacity to understand the implications of their actions. Generally, children are not deemed to have the capacity to enter into enforceable contracts because they do not have the maturity to understand all the implications of their actions. People who are insane or temporarily incapacitated due to injury or medication may not be capable of understanding their actions. Often, contracts made with a party who lacks capacity are enforceable but may be cancelled at the option of the party who lacks capacity or by his or her representative. Therefore, it may be a very bad idea for a person with capacity to enter into a contract with someone who does not have capacity. If the contract proves to be to the advantage of the capable person, the person without capacity can cancel it; if the contract is to the advantage of the person without capacity, they can choose to enforce the contract. Likewise, a valid contract is not formed when one of the parties is under duress. If someone enters into a contract due to threats made by the other party, then the contract is not enforceable. 
Finally, a contract with an illegal purpose is unenforceable. I cannot make an enforceable contract with a thief to have him steal a car for me. No court would enforce such a contract, and I would be committing a crime by attempting to negotiate such an agreement. Therefore, a contract is only valid if its purpose is lawful.

\section{Exceptions to the Requirements of Contract Formation}

Under some circumstances, courts may determine that a contract exists even if not all the requirements listed above have been satisfied. One of these circumstances is called detrimental reliance. Detrimental reliance occurs when a person makes a promise that would not usually meet the requirements of a contract and takes sufficient actions to fulfill the promise such that the other party should have been able to justifiably rely on that promise.

An example of this might be if a rich relative promised to give a couple enough money to buy a house for their wedding and gave them a portion of the money at the wedding with the promise that he would give them the rest of the money shortly. In reliance on that promise and with the relative's knowledge, the couple enters into a contract to buy the home. A few days later, the relative informs the couple that he no longer wishes to give them the full amount. In this case, a court might find that the couple justifiably relied on the relative's promise and that the relative, therefore, should be required to fulfill that promise.

Another circumstance in which a court may imply the existence of a contract is the event of a mistake where a person who was not originally a party to the contract benefits from the mistake. A contract might be implied by a court if a fertilizer salesman accidentally delivered fertilizer to the neighbor of the farmer who contracted for the fertilizer if when he received the fertilizer, the neighbor used it on his own farm or simply refused to return the fertilizer after the mistake was discovered.

\section{Incomplete Contracts and Default Rules}

It would be nearly impossible for a contract, other than those for a single immediatelycompleted transaction, to incorporate provisions for all possible scenarios that could arise in the future. Parties cannot anticipate all the events that could occur that might influence the parties' obligations under the contract. Therefore, their contract is likely to be silent about these uncertainties. Similarly, some contingencies may purposely be left out of a contract because the parties view the potential for that outcome as unlikely and discussion of such a contingency might seem like a waste of time or might pollute the negotiating atmosphere. For example, it would probably be very bad for the negotiating atmosphere for you to insist upon a clause in a contract we are negotiating that specifies what happens in the event I am convicted of a crime and executed. This might cause me to become offended and to refuse to enter into any contract with you.

What should be done in these cases? Should a court create new terms that the court deems fair given the circumstances that have occurred? Would such "gap filling" by the court 
undermine the voluntary consent of the parties that takes place during the formation of a contract?

Although courts do sometimes use their equitable powers to "fill in the gaps" of an incomplete contract after the fact, frequently these incomplete contracts are dealt with using default rules. Default rules are terms that are implied to be part of every contract unless a provision of the contract explicitly specifies a different term will be used. Default rules may vary depending upon the legal tradition of any given country. For instance, if the default rule in Afghanistan is that a contract remains in effect forever, the court will assume that the contract is perpetual unless a provision of the contract specifies a time when the contract will terminate.

The law may also establish mandatory rules that create implied terms that cannot be negated by the parties because the rule is seen to serve a positive social objective. For instance, many jurisdictions in the United States include an implied covenant of good faith and fair dealing in all contracts. Parties may not opt out of the requirement that they deal with their counterparty fairly.

\section{Assignment and Delegation}

Sometimes a party to a contract may wish to transfer the benefits of the contract to another party. For example, a merchant may be obligated to deliver one ton of flour to me every month. I may decide to transfer my right to receive that flour to another person. Such a transfer is called an assignment. Generally, assignments are allowed as long as the contract does not explicitly forbid them.

A party to a contract may also wish to transfer her obligations under a contract. For instance, the merchant who is required to deliver one ton of flour to me may wish to transfer that obligation to another merchant. This transfer of obligations is called a delegation of contract duties. Generally, delegation is not allowed if the contract obligates a party to perform personal services that are unique. A famous musician could not delegate his obligation to perform a concert to another musician. Additionally, even though a person delegates her obligation to another party, she remains liable in the event the obligation is not performed, unless the nondelegating party explicitly releases her from her obligation.

\section{E. Remedies for Breach of Contract}

What should be done when a contract is breached? This is one of the most important aspects of contract law, since without an effective means of enforcing the contract (or remedying the damage caused by the breach of that contract), there is really no point in entering the contract in the first place. When a party to an enforceable contract fails to perform his obligations, a court must determine what remedy the other parties should receive to compensate them for the damages caused by the breach of the contract. Money is most commonly the compensation awarded to the non-breaching party. Courts attempt to award a non-breaching party with an amount of money equal to what she would have expected to receive had the contract been fulfilled. 
However in some cases, a breach and its resulting loss to the non-breaching party may be difficult to quantify in monetary terms. In those situations, a court might order the breaching party to take a specific action to compensate for the breach. This is called specific performance. A court is most likely to order specific performance when the damage caused cannot be accurately or adequately compensated with money. For instance, if I contract to sell you an exceptional racehorse and then change my mind, the court is likely to order me to sell you the horse because it is difficult to determine an amount of money that would accurately compensate you for the loss of the horse.

The parties may specify in the contract the amount of damages if there is a breach. These specified damages are called liquidated damages. Liquidated damages allow the parties to know with greater certainty what the damages will be if there is a breach. This is particularly useful when the damages are uncertain and difficult to calculate. Courts will sometimes invalidate liquidated damages provisions in a contract if the court determines the liquidated damages are being used as a means to penalize a breach rather than to accurately compensate the nonbreaching party.

Liquidated damage provisions are often prohibited because they prevent efficient breaches of contract, where it is cheaper for one party to breach and compensate the nonbreaching party than it is for the breaching party to fulfill the contract. Some courts believe such breaches should be allowed as long as the damages awarded to the non-breaching party are sufficient to compensate her for the losses she has incurred.

How courts deal with breach of contract depends largely on how contract law deals with the policy tension inherent in many areas of commercial law that we introduced at the beginning of this chapter. The way that a court decides to award damages in a contract dispute must balance the need to protect a contracting party who is damaged with the need to provide incentives for all parties to enter into a contract in the first place. Parties may want strong enforcement and large damages to create greater certainty that the contract will be fulfilled, but at the same time parties may be discouraged from entering into contracts if it is likely they will face excessively high damages in the event of a breach.

\section{F. Realities of Contract Law in Afghanistan Today}

Much of the new legal framework necessary to govern agreements between private parties and to encourage and protect private investment in Afghanistan is still being designed. Additionally, there are overlapping systems that govern disputes between parties (customary law as implemented by shuras and the formal legal system instituted under the 2004 Constitution), and these different systems have yet to be fully harmonized. A commercial court system is in the process of being established, but few commercial courts outside of major cities are functional today. International businesses do not use the commercial courts that are functioning because outcomes from the court are likely to be uncertain since there is still no official contract law and court decisions tend to be unpredictable. The commercial court still has relatively limited ability to deal with complex commercial disputes. 
However, many aspects of commercial law are improving, and drafts of a contract law and an updated commercial code are under consideration. A new Contracts Law (including an Agency Law, discussed later in this chapter) is being drafted. The Ministry of Commerce and Ministry of Justice set the goal that the Contracts Law would be adopted in 2008, but this goal was not been met. Once this law has been officially adopted and implemented, the outcomes of commercial disputes are likely to become more predictable, and the legal system is more likely to be used to resolve those disputes.

Given the transitional state of contract law in Afghanistan, the legal system has not played a significant role to date in adjudicating commercial disputes. Most businesses tend to use informal mechanisms to resolve disputes and enforce property rights. For example, the Afghan Investment Support Agency "AISA" (discussed in more detail later in the chapter) sometimes assists investors in mediating disputes. It is common for investment disputes to arise out of contracts, and the absence of a clear contract law has resulted in the near unenforceability of commercial agreements through formal means. The Private Investment Law provides some mechanisms for dispute resolution, under United Nations Commission on International Trade Law (UNCITRAL) rules or under any mechanism an investor has specified in a contract. However, these provisions are untested, and disputes continue to be solved through customary means such as shuras.

Some mechanisms at the international level can be used to settle disputes between Afghan and international parties. Afghanistan is a party to the Convention on the Settlement of Investment Disputes between States and Nationals of Other States as well as the New York Convention of 1958 on the Recognition and Enforcement of Foreign Arbitral Awards. These international agreements provide a forum and framework for the settlement of disputes with international parties. Generally, if a contract is entered into with international actors (whether a business, a nonprofit, or the UN), then the parties typically choose to include an arbitration clause in their contract that stipulates resolution under another country's contract law.

Recently, two new laws have been enacted to provide a means for commercial dispute resolution on a national level. The first law, the Commercial Mediation Law, provides a framework for parties to informally settle disputes in a more formalized way. Informal mediation has been a common means of commercial dispute resolution in Afghanistan, but this law seeks to make such informal mechanisms more effective. The law specifies how parties to the dispute will appoint a mediator and how the mediation will be conducted. It also provides guidance to courts about how a settlement through mediation should be viewed and enforced.

The second law, the Commercial Arbitration Law, allows parties to specify arbitration as the means to settle a commercial dispute. Arbitration can be specified to take place either domestically or internationally. In either case, courts in Afghanistan will not rule on the dispute and instead will refer it to the specified arbitration authority. Perhaps most significantly, arbitration agreements may specify that the law of any jurisdiction be applied to the agreement. Therefore, although a Contracts Law has not been approved, parties can choose to apply the contract law of another country to their agreement. The adoption of these new laws is an 
important step in creating a system that will make contracts in Afghanistan more easily enforceable.

\section{G. Sources of Contract Law in Afghanistan}

Historically, Afghanistan has derived its contract law from multiple sources. Local, tribal, and national customs speak to the formation and fulfillment of agreements between people; Islamic legal texts also provide guidance on a variety of interactions between people that have often been applied to contracts; and statutes put in place under previous governments in Afghanistan provide contracting rules that continue to influence the interpretation of current contract law. The variety of sources from which Afghanistan derives its contract law demonstrates that contract law tends to evolve over time to meet the needs of the current circumstances.

\section{Custom}

In many cases, local leaders or village councils (shuras) settle disputes related to agreements between parties. When this is the case, it is up to those leaders or shuras to decide whether a contract had been formed, whether someone failed to fulfill their obligations under the contract, and what the solution should be in the case that a party is found to have failed his obligations.

Many areas of Afghanistan have their own customary law that binds people in a certain location or of a certain tribe or other group. Customary law uses community norms to govern interactions between community members. This has proven to be an effective means of settling disputes in many cases, but it can also be problematic since the decisions tend to be unpredictable: decisions vary from place to place and from group to group, making it difficult for people to do business in different areas of the country or with different groups. Local customs are rarely recorded, and the specific interpretation or implementation of many customs can vary widely in different parts of the country.

Additionally, local leaders or members of shuras are frequently parties to the agreements that are in dispute, or they have individual interests that could be influenced by the decision made in the case. This creates the potential problem that decisions will be made to benefit the members of the shura rather than to enforce the actual meaning of the agreement. For example, in a dispute between a businessman from Herat and a businessman from Khost, the businessman from Herat is unlikely to feel confident that a shura in Khost will make an fair decision. The same is probably true for a businessman from Khost doing business in Herat and subject to a decision by a Herati shura. The businessman from the other region may think that the shura will protect the interests of the local, even if the facts or custom favor the outsider. Due to his lack of confidence in local customs to protect his interest, the Herati businessman may choose not to do business in Khost. Although greater business connections between Herat and Khost would benefit both communities, those connections will not be built because the people lack confidence in the ability of local customs to protect the interests of outsiders. 


\section{Islamic Law}

Islamic law is an important source of contract law in Afghanistan. In keeping with Article Three of the Constitution, prior to the adoption of commercial laws in Afghanistan, all laws are vetted for compliance with the principles of Islam. Generally, Islamic law asks that valid contracts between parties be enforced and as a result, gives great deference to the right to contract freely, unless Islam specifically prohibits a contract (such as gambling-related contracts).

Islamic law is a source of jurisprudence related to the interpretation of contract law in Afghanistan. Article 130 of the 2004 Constitution states that when the Constitution or other laws do not provide guidance on a legal issue, then Hanafi jurisprudence may be applied so long as it is within the bounds of the Constitution. Article 131 also allows for the use of a Shia version of Islamic jurisprudence (generally implying the Ja'fari school of jurisprudence) when the legal issue deals with "personal matters of followers of the Shia sect."

Statutes enacted before the 2004 Constitution also provide similar guidance for the application of Islamic law. The Civil Code of 1977 states that "where the law has a provision, the practice of religious jurisprudence is not permitted..." When there is no such provision in law, "Hanafi jurisprudence, public conventions, and precedent" are to be followed, so long as laws are only repealed or amended through express legislative action. The 2004 Constitution and the Civil Code of 1977 both place limitations on the issues that should be addressed directly under Islamic jurisprudence. Since law in Afghanistan has been drafted in compliance with Islamic law, the legal code is the primary source that courts consult for resolving contract issues. But when the code is silent, Islamic jurisprudence is applied to the facts of the case.

The approach of the Hanafi and Ja'fari schools to the application of Islamic law governing contract disputes is outside the scope of this text. Even if we were to attempt to present the rules of contract law under Hanafi and Ja'fari jurisprudence, it is difficult to summarize how Afghan judges apply those schools of jurisprudence. As the sources used to make legal interpretations of Hanafi and Ja'fari jurisprudence are diverse, it is difficult to determine how an individual judge might apply a given form of jurisprudence.

The difficulty of summarizing the Islamic jurisprudence is magnified by the fact that Islamic courts do not have a tradition of adherence to precedent and the holdings of courts are not publicly reported due to the fact that decisions are generally handwritten. Therefore, it is difficult to determine if similar decisions are made in cases with similar facts. As a result, contracting parties must still deal with a great deal of uncertainty when they try to determine how an Islamic court will look at their agreement.

\section{The Commercial Code of 1955}

A statutory commercial code (referred to as the "Commercial Code of 1955" or simply the "Commercial Code") that addresses several aspects of contracts law was adopted in 1955 and designed to apply to all commercial transactions as specifically determined by the provisions of the Commercial Code. The Commercial Code has served as the primary source of commercial 
law since 1955, and the 2004 Constitution provides that laws enacted before 2004 remain in force unless explicitly repealed or superseded by a new law. It is not completely clear which parts of the Code have been superseded by new laws. However, the new Corporations and Limited Liability Companies Law and the new Partnership Law both explicitly render void those provisions of the Commercial Code that deal with corporations, limited liability companies, and partnerships.

One of the key provisions of the Commercial Code specifies that disputes are to be resolved through reference to "the meaning and implication of existing commercial laws." In other words, commercial law should be the first source that is used to determine the proper outcome of a dispute. "In the absence of a law, local and special customs" are used, with preference given to local custom over general custom.

Although the Commercial Code is the primary source for resolving disputes related to commercial transactions, application of the Commercial Code is specifically limited to commercial transactions. Articles 18 and 19 of the Commercial Code provide lists of transactions that qualify as commercial transactions. They include: agreements to provide movable property; establishment of several types of businesses; transportation services; and distribution services.

Chapters III and IV of the Commercial Code deal directly with the use of contracts in commercial transactions. Chapter III outlines specific formalistic requirements for commercial contracts, documents, instruments, and agreements. Chapter III covers bills of exchange (contracts for the exchange of goods or services), transfer endorsements for negotiable notes (transfer endorsements are contracts that transfer the rights to a negotiable note from one person to another, and a negotiable note is a written or printed paper that acknowledges a debt and promises payment that is transferable between parties), documentation and processes needed to accept and guarantee negotiable notes, and documentation required in conjunction with the payment of such obligations. It also specifies the requirements of negotiable instruments such as promissory notes and checks. These formalistic requirements, dealing with things such as how a specific instrument must be titled on the document and what provisions must be contained within the document, create certainty as to the type of contract into which the parties are entering. Such requirements force the parties to be clear about the rights and obligations they are subjecting themselves to.

Chapter IV of the Commercial Code addresses the formulation of commercial contracts more generally. It specifies the means by which parties may create a valid and enforceable contract through mutual consent as determined by offer and acceptance of the agreement. Additionally, Chapter IV covers many of the rights and responsibilities created by a contract, such as the means for revoking a contract and other issues related to performance and breach of the contract. Some of the provisions related to methods of offer and acceptance that form a valid contract are provided below: 


\section{Commercial Code of Afghanistan}

\section{Article 608}

In order for a commercial contract to take place, the consent of both parties is sufficient. Preparation of a contract or other ceremonies is not necessary.

\section{Article 609}

If it is required by the law that the contract be written on a special form, or if both parties delay the contract for certain ceremonies, the contract cannot take place without that form or before those ceremonies. . .

\section{Article 610}

If it has been necessary to specify a period for acceptance, acceptance cannot take place before the end of that period, even if both parties agree. If an agreement should be necessary without specifying a period of acceptance, the validity of acceptance is conditional to the immediate acceptance and presence of the parties concerned. A contract made by communication means, such as telephone, is as if it had taken place in the presence of the parties concerned.

\section{Article 611}

When the act of acceptance takes place in writing, if the period is not determined, the contract initiator cannot disregard the act of acceptance before the termination of the time necessary for thinking and positively answering by the acceptor.

\section{Article 612}

The acceptance answer should be sent during a specified period that should reach the contract initiator. If the answer comes after this period, the contract does not take place unless it is found that the acceptance answer has been given during the specified required period. The contract initiator must at once inform the other party about the delay in receiving the answer being responsible for the contract not taking place. Otherwise, the contract is valid.

\section{Article 613}

Lack of response by the other party does not imply acceptance. In case two members have permanent commercial relations, or if one of them requests the other to execute certain transactions in his name, the decision made by the person referred to should at once be made known to the opposite party, or else the lack of response is considered as acceptance. They party rejecting the initiated proposition has to take special steps about the goods sent to him when the proposition was made, as mentioned in Articles 762 and 763.

\section{Article 614}

If the acceptance's answer is not in agreement with the proposition, the contract does not take place. In such case, the acceptance necessitates another proposition.

\section{Article 615}

In order for a telegram concerning the proposition or the acceptance to be acceptable, it is necessary that it be proved that it contains the signature of the sender or has been sent with his consent. 


\section{Article 616}

In case the proposition is made in writing, the contract takes place from the date of arrival of the acceptant's answer to the proposal; but if the proposer should be informed before the arrival of the answer or during this time of the rejection by the acceptant, the proposition is without effect.

\section{Article 617}

A contract taking place by communication is valid from the date the acceptance answer has been sent. Just as mentioned in Article 613, in case it is not necessary that acceptance be explicit, the contract is in effect from the date the proposition has reached the addressee.

\section{Article 618}

The death or disqualification of a merchant does not necessitate the invalidity of his proposition in acceptance concerning his commercial transactions unless otherwise explicitly mentioned or understood from the nature of that transaction.

The above provisions make it clear to the parties when a valid contract has been formed.

Chapter IV of the Commercial Code also provides the rules for interpreting the provisions of a commercial contract:

\section{Commercial Code of Afghanistan}

\section{Article 619}

If the meaning of the statement of a commercial contract should be explicit and logical, the apparent meaning is assumed. Otherwise the real purpose is honored. If the content of the statement is inconsistent with that of the contract, the interpretation of purpose is held applicable.

\section{Article 620}

In case a statement has [multiple] interpretation[s], the common purpose is determined from the contents of other contracts, [from] custom, or [from] the transactions and circumstances prevailing at the time of the preparation of the contract, or according to previous applications.

\section{Article 621}

In case the statement should have unusual and common meanings, it is interpreted as according to which meaning it is closer to.

\section{Article 622}

In case the statement of the contract should be interpreted with many meanings, and according to Article 620 the real purpose of both parties should not be determined, the contract is interprete[d] against the person promising and for the person to whom the promise has been made. 


\section{Article 623}

Recognition is given to commercial custom as well as to legal orders in commercial transaction unless otherwise explicitly agreed to by both parties.

These rules of interpretation allow contracting parties to know in advance how a court will evaluate the terms of their contract in the event of a dispute and bring greater consistency to judicial rulings. Do you think these rules provide any way to imply terms that are not explicitly present in the document? Analyze these rules of interpretation while referencing our discussion of incomplete contracts and default rules. Would you characterize these rules of interpretation as default rules?

\section{The Civil Code of 1977}

A statutory civil code (referred to as the "Civil Code of 1977" or simply the "Civil Code") that addresses other issues of contract law was adopted in 1977. This code suffers from some problems that make it an imperfect source of contract law today. The first issue with the Civil Code is its questionable validity due to the recent adoption of several new laws. As with the Commercial Code, the Constitution provides that laws enacted before 2004 remain in force unless explicitly repealed or superseded by a new law. It is not completely clear which parts of the Civil Code have been superseded by new laws. The Civil Code also uses many Arabic legal terms that are not common in the Dari or Pashto languages and are not defined in the text of the code. Therefore, the interpretation of the code can be uncertain. Nonetheless, the Civil Code is one important source of contract law concepts that influence current court decisions.

The Civil Code addresses many legal rules related to key aspects of a contract including determining the applicable law for a given situation; determining legal personality (who or what can be deemed a legal person); property rights; and rules of contract formation, interpretation, and termination. Many of these concepts will be examined in greater detail later in the chapter. Under the Civil Code, several key legal connections are outlined that allow for a variety of business interactions between parties.

First, the law that is applied to a contract can be determined by the jurisdiction of the place of residence of the parties, by agreement of the parties, or by the location where the contract was formed, depending on the specific circumstances. Second, the Civil Code recognizes entities such as companies and other organizations as legal persons who are able to enter into a contract or bring a claim under contract law in court against another person just as a real (or natural) person may. It also recognizes the ability of one person to serve as the representative (also called an agent, discussed further below) of another person when creating a contract. Third, the code provides that property rights such as easements, security for credit (an Islamic mortgage, for instance), and liens may be created through contract.

The Civil Code also addresses the methods that may be used for formation, interpretation, and termination of a contract. When a contract is formed, there must be a "meeting of minds of the parties under which one party is obligated by consent. The contract is formed through offer and acceptance, freely communicated in a way that clearly shows intention to contract, and may be implied or made by bid, delivery, silence, or mistake unless the other party is aware of the 
mistake." It further specifies that an offer remains open until it is "withdrawn, superseded by another offer, expires, is rejected or counter-offered, or the offeror loses capacity" (Country Handbook on Afghanistan).

Interpretation of a contract's meaning is achieved through the application of standard rules of construction contained in Articles 705 to 729 of the Civil Code, but the code stresses that there should also be some deference to custom when interpreting the meaning of a contract.

A contract may be terminated when its purpose is completed, by agreement of the parties, or by the judgment of a court. The Civil Code additionally provides that a court may hold a contract invalid for a variety of reasons, such as exceptional and unforeseeable circumstances that would cause one party extreme loss.

A court also could refuse to hear a complaint based on a contract that was entered into more than fifteen years before the complaint was made. A court could refuse to hear a complaint more than five years after the contract was made if the contract dealt with salaries, rents or taxes. And a court could refuse to hear a case after one year if the contract dealt with workers' wages, professional fees, or hospitality charges.

These rules of interpretation and limitations on the term of a contract combine to provide greater certainty that the outcome of a contract dispute will be as close as possible to what the parties intended when they entered into the contract.

The Civil Code also creates special provisions for contracts that are for special types of transactions. For instance, contracts dealing with the transfer of ownership of property and certain construction contracts include implied warranties against defects in the transferred goods to create incentives for sellers to sell quality goods and to discourage fraud. Contracts for partnerships are required to be in writing and to specify the ways in which the partnership will be administered. This helps ensure that in the event of a dispute, a court will be less likely to have to reconstruct what the parties intended when they entered their partnership.

Contracts for loans of money or goods are allowed under the Civil Code, but certain provisions are required to ensure that the loans are in compliance with interpretations of Islamic law that forbid profit on those loans (faida). The code similarly specifies that leases (ijara) be in compliance with certain requirements, such as a specified rent amount and a predetermined length of the lease.

Some of the other areas of contract law addressed by the Civil Code include: provisions for settlement of disputes prior to a court's judgment; contacts with public utilities where the government is a party; labor contracts for skilled labor; and insurance contracts such as life or fire insurance. In each case, it is likely that these particular contracts contain common issues that could most easily be addressed by a rule that could be universally applied.

The Civil Code provides a useful source of contract law theory and demonstrates that Afghanistan has a history of implementing the use of contract law and of tailoring contract law to a wide range of transactions. Although the 2004 Constitution was adopted after the Civil Code 
and many new laws supersede some sections of the code, the Civil Code can provide a useful means of exploring the ways that Afghanistan has dealt with contract law in the past and what issues should be addressed by contract law in the present and future.

\section{Discussion Questions}

1. By what means are contracts enforced in Afghanistan today?

2. What steps is the government taking to deal with the lack of a coherent and established contract law and reliable enforcement mechanism?

3. How have you seen business disputes resolved in your daily life? Was this an effective way to resolve the dispute? Was the result fair? Was the outcome predictable before the dispute occurred?

4. What sources have historically served as the basis of contract law in Afghanistan?

5. What are the benefits and drawbacks of various sources of contract law that have been used in Afghanistan?

\section{BUSINESS ORGANIZATION}

When people decide to start a new business, they must decide how the business will be owned. Many businesses are owned by one person. In such cases, that person receives all of the profits and is responsible for all the debts of the business. This type of business is sometimes referred to as a sole proprietorship.

When the business is owned by multiple people who share the profits and liability for the debts of the business, the business is called a partnership and the owners are called partners. In some cases, partners could form a partnership that is legally separate from the individual partners. This means that individual partners are only responsible for the debts of the partnership up to the amount that they have invested in the partnership. Such a partnership is called a limited partnership because the liability of each partner is limited. Generally, however, under the Partnership Law of Afghanistan, at least one partner in a partnership is fully liable for the debts of the partnership.

A corporation is a third type of business organization. Corporations are legally separate from their owners. Multiple people may own portions of the corporation. These portions of ownership in the corporation are usually called shares or stock. A corporation may sell its stock, possibly to the public at large, which allows the corporation to raise money to start the business or to invest in its operation or expansion. Individual owners of stock may also sell their stock if they choose, again possibly to the public at large. The investors are not responsible for the corporation's debts. As with a limited partnership, owners of corporations have limited liability. In the event the business fails, investors will only lose the value of the stock that they purchased. 
The Corporations and Limited Liability Companies Law of Afghanistan defines a corporation as a "business company whose capital is definite and divided into shares, with the share and responsibility of each shareholder limited to the proportion of his share."

For the most part, corporations around the world share several distinct features: (1) they are considered legal persons with an indefinite life; (2) investors enjoy limited liability; (3) shares or stock in the company are freely transferable between parties in most circumstances; (4) the company is centrally managed (usually by a board of directors); and (5) management is appointed by the company's owners (shareholders). These features create advantages that might make it preferable to other forms of business organizations. For instance, there is no personal liability for investors; it is easier for individual investors to withdraw their investment while the business continues to operate; the structure allows for easy transfer of ownership without modification or dissolution of the company; and management is more centralized than with most partnerships.

One disadvantage of operating a business as a corporation is that it is often more expensive to set up and requires that the business comply with more government regulations. Still, in developed countries, corporations account for a majority of the total sales made in those countries' economies.

A limited liability company (LLC) is similar to a corporation, but it has some traits similar to a limited partnership. The Corporations and Limited Liability Companies Law of Afghanistan defines a LLC as "a business company whose capital is not divided into shares with the responsibility of each shareholder limited to the amount of capital agreed to [by such shareholder] in the company." Furthermore, an LLC cannot have less than two or more than 50 owners, its shares cannot be traded on a public exchange, and shareholders are not authorized to sell, transfer, or exchange the shares of the company.

Previously, the Commercial Code of 1955 and the Civil Code of 1977 governed the formation of business organizations in Afghanistan. However, the new Corporations and Limited Liability Companies Law and the Partnership Law superseded the sections of the Commercial Code and Civil Code dealing with partnerships and companies.

\section{A. The Corporate Person}

Corporations are separate persons under the law. This is a critical distinction that supports all the characteristics of a corporation we have discussed above.

Consider, for example, the simple act of acquiring a plot of ground. As a buyer, the corporation, acting through its authorized agents, may sign binding contracts, close sales, and so take title in its own name. Thereafter, it may deal with the acquired property as its board of directors deems expedient. Because its principal investors need not execute the transaction or even agree to it, the information and coordination costs of closing the transaction are minimal. Consider, too, the way 
in which a corporation's ability to own assets as a legal entity enables it to enter into contracts, such as bank loans. Creditors need to know what stands behind a company's promise to pay interest and principal. Enabling corporations to own assets-including businesses-delimits the pool of assets upon which corporate creditors can rely for repayment. If there were no separate corporate entity, a large creditor would be forced to investigate the asset holdings and creditworthiness of all the joint venturers-i.e., the company's shareholders-on the loan. Thus, the doctrinal fiction of an artificial entity vastly reduces the costs of contracting for credit.

In addition to economizing on the monitoring costs of creditors, the status of the corporation as a fictive legal entity allows it to have an indefinite "life." This enhances the stability of the corporate form. Even without complex drafting, the death or departure of a "principal need not disturb the operation of a corporation, as it would a partnership" (Allen and Kraakman 2003:83).

\section{Discussion Questions}

1. Why is efficient business regulation important to economic development?

2. What are the key benefits of creating a corporation compared to other business forms?

From a different perspective, it is also possible to view a corporation as merely a combination of many contracts. In other words, the corporation serves as "a single contracting party that coordinates the activities of suppliers of inputs and of consumers of products and services" (Kraakman 2004). This "legal fiction" that the corporation is a legal person facilitates and centralizes many complex contracts between investors, lenders, suppliers, customers, the government, and the public in general.

\section{B. Limited Liability}

Limited liability is granted to owners of some companies and partners in some limited partnerships. When an owner of a company has limited liability, his financial liability for the debts of the company is limited to a fixed amount, usually the value that the owner has invested in the company. Sole proprietors and members of partnerships without limited liability are liable for any and all debts of their businesses.

For instance, imagine that you are the sole proprietor of a computer shop. You have taken out a loan to buy inventory (computers you intend to resell). Before you are able to sell the computers, someone breaks into your shop and steals the computers. The police attempt to find your computers but are unsuccessful, and you have no insurance to replace the computers. With no inventory to sell, your business has no way to repay the loan. As you are a sole proprietor, the person who made the loan to you could ask a court to seize your personal assets (perhaps your car or your home if the debt is large enough) as repayment of the loan. Had your business been a 
partnership or company with limited liability, you would not have risked losing your personal assets.

Limited liability has certain general economic benefits. It encourages people to take risks and start businesses that might be very successful but that also might fail (as in the case of your computer shop). Since the person starting the business knows they will not be personally liable for the debts of the company if it fails, they may still be more willing to take the risk to start the business. Society wants people to take the risks of starting businesses since businesses drive economic growth.

However, there is also an argument that limited liability creates too much incentive for entrepreneurs to carelessly take on risk that in turn imposes costs on the rest of society. For example, when a business whose owners have limited liability fails to pay its debts, the people who made loans to the business lose money since they cannot go after the assets of the owners of the business. To make up for that loss, they pass on the cost by charging more for loans to businesses that actually repay their debts. Therefore, successful businesses indirectly end up paying for the bad debts of failed businesses.

\section{The Law on Private Investment in Afghanistan}

The Law on Private Investment in Afghanistan (referred to as the "Investment Law") was enacted based on Article 10 of the 2004 Constitution. Article 10 states that the legal system of Afghanistan should allow a free market economy to develop and should encourage and protect investments and private businesses. As stated in its text, the purpose of the Investment Law is to:

maximize the role of private investment, both domestic and foreign, in the economy, to create a legal regime and administrative structure that will encourage and protect foreign and domestic private Investment in the economy of Afghanistan in order to promote economic development, expand the labor market, increase production and export earnings, promote technology transfer, improve national prosperity and advance the people's standard of living.

Thus, the central goal of the law is economic growth through private investment. To achieve this goal, the law establishes a system that will create favorable conditions for both foreign and domestic investment.

To do this, the Investment Law specifies the means by which investment may be regulated. It outlines areas where investment may be prohibited or restricted and sets out the way in which investment will be administered and monitored. The Investment Law provides that the High Commission on Investment (the "Commission") is the government authority with responsibility for implementation of the Investment Law.

One of the key requirements of the law is that investors must register their businesses to operate in Afghanistan. This requirement is critical to the goals of the Investment Law since overly onerous or complicated registration requirements could deter the investment that the law 
seeks to attract.

To register, an enterprise must be recognized by the Government of Afghanistan according to the Investment Law's provisions. Registered enterprises may be organized under the laws of Afghanistan or under the laws of another country, but the business must still be registered with the Government of Afghanistan. This is beneficial to foreign businesses since they are not required to reorganize to do business in Afghanistan. They are only required to register. Registered enterprises in Afghanistan are also allowed to be completely owned by investors or may be joint ventures between investors and the Government of Afghanistan. Therefore, the law allows investors to choose to operate independently or as partners with the government depending on what is most advantageous to their business interests.

Another key aspect of the Investment Law is that it provides that registered businesses and foreign investors have important rights and responsibilities when they make investments in Afghanistan. The responsibilities of investors include paying income tax and customs duties on any capital or profits associated with their investments. The rights of an investor include compensation for any government expropriation of the investment and the ability to make a contract that provides for arbitration or alternative dispute resolution in or outside of Afghanistan. As noted above in the contract law section, the contract may also specify that the laws of a jurisdiction other than Afghanistan may apply to the contract and the resolution of the dispute. These rights are particularly important to encouraging investment since an investor, particularly a foreign investor, can choose to use a means of dispute resolution that is most likely to protect his or her interests, and there is less danger that he or she will be forced to use a forum in Afghanistan that may be biased against his or her interests. With such protections, investors are likely to find Afghanistan to be a more attractive investment opportunity.

\section{Issues Related to the Operation of Business Entities in Afghanistan}

Afghanistan has been relatively proactive in its attempt to establish a streamlined system for registering a business. It was ranked 16th out of 155 countries for ease of registering a business in the World Bank's 2005 “Doing Business Report." However, this ranking is deceptive due to the many lengthy processes that businesses must complete following registration.

In addition, just because a process is easy does not mean it is effective at achieving its purpose. In a survey of businesses in 2005, regulatory issues such as business registration, tax administration, and labor law were not cited as significant obstacles. This is because they are poorly enforced and hence do not impact most businesses.

The current process for starting a business in Afghanistan can be relatively costly, and although registration can be accomplished quickly, the rest of the process can take a great deal of time. There are many steps in the process, and it can be difficult for an entrepreneur get the information he or she needs to determine what steps must be completed in order to comply with the law. This can be a problem because it can negatively affect the ability and willingness of entrepreneurs to invest. It also creates opportunities for corruption because entrepreneurs cannot challenge government officials who are misusing the registration and licensing process for their 
own benefits. The entrepreneurs do not know what the correct procedure is, so they are unable to determine if government officials are acting properly.

Lack of information is another key obstacle for investors. A few government agencies provide information about their respective licensing processes, but this needs to be done more widely. The lack of information makes it more difficult for investors to comply with regulations and thereby increases the power of government officials who then have the power to determine what penalty should be imposed for noncompliance. A nontransparent process also creates greater opportunities for corruption.

The inefficiency of registration and licensing procedures is another area of concern. Entrepreneurs are often required to take their own paperwork through the entire process. Due to the fact they are outsiders who may have never undertaken the process before, they have little power to speed the process. Many government organizations begin their approval process with high-level officials instead of low-level functionaries. This slows the process and gives highlevel officials a great deal of power to influence individual companies instead of managing their organizations and allowing low-level officials to deal with individual businesses. In addition, approval of one license may require the approval or license of another government organization. This means that a delay in the approval of one government organization can put the entire process on hold.

Another problem that complicates entrepreneurial efforts is the number of licenses currently required to operate a business. In twenty-two economic sectors, a business must register with the Commercial Court (see below), obtain an Afghan Investment Support Agency license (see below), and obtain a license for the sector in which it operates. It is unclear why the sector license is required. Again, the additional requirements increase the complexity of starting a business, thereby deterring economic activity, and they also encourage corruption by officials who have the power to prevent a business from operating.

Simplifying the process of starting a business and streamlining business licensing and start-up processes encourages new entrants to the economy. This facilitates job creation and drives income growth. It also reduces the temptation for government officials to take part in corruption.

\section{E. Role of the Afghan Investment Support Agency}

Foreign and domestic investment are both critical to Afghanistan's economic growth, and the Afghan Investment Support Agency (AISA) is tasked with promoting and licensing these investments in the most efficient means possible. "In short, AISA has been created in order to attract, facilitate and promote domestic and foreign investment in Afghanistan."

As part of its mandate to create a single point of interaction between investors and the government, AISA's responsibilities include providing businesses with permits, licenses and clearances; providing information on investment opportunities; providing information to investors on investment, tax, labor, insurance and environmental laws and regulations; providing 
information on Afghanistan's unique social structure; providing information on banking, labor costs, and the availability of investment incentives; assisting businesses with real estate acquisitions and leases; facilitating customs clearance for investment related imports; and promulgating news related to investment opportunities in Afghanistan through conferences, symposiums, foreign embassies in Afghanistan and embassies of Afghanistan abroad.

\section{AGENCY THEORY}

The Commercial Code of 1955 includes a section on agency, and the proposed Contracts Law is also expected to include a new Agency Law. Agency is an important concept for social and business organizations. The concept of agency can be applied to government organizations, corporations, partnerships, and other forms of hierarchical or representative organizations.

The Third Restatement of Agency Law defines agency as "the fiduciary relationship that arises when one person (a "principal") manifests assent to another person (an "agent") that the agent shall act on the principal's behalf and subject to the principal's control, and the agent manifests assent or otherwise consents so to act" (Restatement of Contracts 2006: §1.01). In other words, a principal and an agent both voluntarily agree that an agent will act on behalf of the principal, and the actions of an agent can create a binding obligation on the principal, if the agent has authority to make the obligation.

A fiduciary relationship is created when two people enter into an agency relationship. The agent is a fiduciary of the principal. A fiduciary is someone who "must act loyally in the principal's interest as well as on the principal's behalf." As an example, take the case of an agent who is tasked with obtaining cement for his or her principal. It happens that the agent's brother sells cement, but the price the brother charges is twice the price charged by other suppliers for similar quality cement. Although the agent might be fulfilling the principal's need for cement by buying the cement from his own brother for twice the cost, the agent would not be acting in the best interest of the principal since he could have obtained the cement for a much lower price from another supplier. By putting his loyalty to his brother above his duty to act in the interest and on behalf of his principal, the agent in this example is violating his fiduciary duty to his principal.

In addition to the fiduciary relationship, the agent owes the principal whatever other duties are specified when the agent agrees to enter into the agency relationship on the basis of that agreement.

There are two types of authority to act on behalf of the principal that an agent may exert: (1) actual authority; and (2) apparent authority. Actual authority exists when the principal has granted the agent the power to create the particular obligation in question. The principal is liable for the obligations created by the agent because he has explicitly given the agent the power to act on his behalf.

Apparent authority is created when the agent does not have the explicit authority to create the obligation in question, but the actions of the principal leads the counterpart to a contract or other interaction to reasonably believe that the agent acted with the principal's authority. 
For instance, imagine you are a business owner. You provide your employee (your agent) with a uniform, business cards, and a vehicle and frequently allow him to enter into contracts with your customers on your behalf. One day, you tell your employee that he is not to make any more contracts with a particular customer, but the employee disobeys your orders and makes a contract with that customer anyway (perhaps because he forgot your order or because he is friends with that customer). Since it would probably appear to anyone who did not hear you tell your employee not to enter into this particular contract that your employee had authority to do so (he was wearing your uniform, driving your truck, and had entered into such contracts on your behalf in the past), the employee would probably be found to have apparent authority, and you would be liable for the obligations in the contract.

However, just as you would be liable for the obligations of the contract, your employee would be liable to you for breach of his fiduciary duty as your agent. If you lost money due to your employee's unauthorized contract, you might have a claim against the employee for those losses. The concept of apparent authority makes it easier for third parties to rely on other people's agents and creates incentives for principals to give clear guidance to their agents and to monitor their actions closely.

All relationships where one person provides services to another do not necessarily satisfy the definition of agency. In order to qualify as an agency relationship, three parties are actually involved: "The principal, the agent, and the third party with whom the agent is to deal" (Mechem $1914: \S 27)$. Therefore, it is the agent's authority to act on behalf of the principal in dealing with other people or organizations.

Application of agency theory to organizations is an important concept for the creation of effective incentives for the organization's principals and its other affiliates such as members and employees. Agency creates a framework for an organization to function as a united entity and also requires principals to take responsibility for the actions of their agents. Since the principals will be held accountable for the actions of their agents, the principals have an incentive to monitor their agents and hold them responsible for misuse of their authority. This results in greater certainty for outside parties who interact with agents.

\section{Agency under the Commercial Code of 1955}

The Commercial Code of 1955 is the legal basis for applying agency theory in Afghanistan until the new Agency Law is approved. Agency law under the Commercial Code varies slightly in several ways from the agency theory that has been described above. Generally, the Commercial Code requires that more formal steps be taken to establish agency relationships. For instance, to be considered an "explicit agent" under Article 88 of the Commercial Code (similar to the concept of actual authority described above), the agent relationship must be registered. Unregistered agent relationships give rise to what the code refers to as "undisclosed agent relationships." In such situations, the rights of the agent with respect to his representation of the principal are unlimited and "include[] all transactions that can be made during that specific business." However, an agent that executes a transaction for his principal without making written note of the agency relationship when signing the transaction documents becomes personally 
liable for the transaction (Article 89). Refer to Articles 85 to 97 and Articles 760 to 820 of the Commercial Code for further rules regarding agency in Afghanistan.

\section{Discussion Questions}

1. What purpose does the concept of agency serve in business relationships and transactions?

2. How does fiduciary duty change an agent's choices when acting on behalf of their principal?

3. How is an agency relationship established generally?

\section{BANKING AND CREDIT}

An advanced industrial economy cannot function efficiently without money. Barteringwhen people exchange goods or services for other goods or services-can still be an effective way for people to exchange products. For instance, in rural areas where many people own goods such as livestock, those goods can easily be exchanged for other goods or services. However, as economies develop and people move into cities, these trades become more difficult. People do not have the ability to keep goods such as livestock that can be easily traded. Money then becomes a much more effective medium of exchange.

Money can also serve as a more effective standard of value. As economies grow and more products become available, it becomes more difficult to compare the relative value of different products in a barter system. I may know that a merchant recently exchanged two water buffalo to another person for eight sheep, but that might not tell me how many kilograms of rice I should expect to pay for two water buffalo. When transactions are done in currency, two different sales are more easily compared. If I know that another person paid 1500 Afghani for a computer recently, I can probably expect to pay a similar amount for a similar computer.

When money becomes the primary means of exchange and store of value, banking begins to play an important role in an economy. People use banks to store the money for which they do not have an immediate need. In return, the bank pays interest on the money a person deposits with the bank. The bank in turn loans that money to people or businesses that want to expand their business or make a major purchase. Banks make a profit by charging a higher interest rate on their loans than they pay on their customers deposits. By making loans, banks allow people and businesses to purchase and use productive resources that they would otherwise not have the ability to purchase. This allows an economy to grow and allows businesses to create jobs. One growing business often generates increased sales for other businesses because it purchases more goods and services to produce its own goods and services. 


\section{A. Banking Laws of Afghanistan}

Two banking laws were adopted in 2004 to create a financial system that could support greater economic development.

\section{Da Afghanistan Bank Law}

Da Afghanistan Bank Law (the "Central Bank Law") created a central bank to regulate the monetary system of Afghanistan and to regulate commercial banks. As stated in the law itself, the purpose of the Da Afghanistan Bank is "to achieve and to maintain domestic price stability." In other words, the job of Da Afghanistan Bank is to prevent price inflation in Afghanistan's market. Other official objectives of Da Afghanistan Bank include "fostering liquidity, solvency and proper functioning of a stable market based financial system, and to promote a safe, sound and efficient national payment system." This means that Da Afghanistan Bank is also responsible for ensuring that it puts enough money into the financial system that the market is able to operate.

The Central Bank Law clearly states that all other purposes of Da Afghanistan Bank will be subordinate to its primary goal of maintaining price stability by preventing inflation. Similarly, Da Afghanistan Bank is tasked with supporting the economic policies of the government of Afghanistan and to create conditions for sustainable economic growth without undermining its primary mission of domestic anti-inflationary price stabilization. Therefore, $\mathrm{Da}$ Afghanistan Bank must balance conflicting objectives. If the bank provides more money to the system, then credit becomes relatively cheap to borrowers. This creates more liquidity and spurs economic growth, but it can also lead to high inflation. If the bank provides less money to the system, credit becomes relatively expensive to borrowers; economic growth is slowed, but inflationary pressure is reduced. Da Afghanistan Bank must attempt to keep the money supply at a level that allows for reasonable growth without encouraging excessive inflation.

\section{Afghanistan Banking Law}

The Afghanistan Banking Law (the "Banking Law") was adopted at the same time as Da Afghanistan Bank Law to create a framework under which to regulate the commercial banking system. The Banking Law addresses several issues related to the operation of commercial banks. It determines the activities that are prohibited for banks and non-banks as well as the sanctions that can result from violations. It also establishes a procedure for public consultation in conjunction with the adoption of banking regulations. This procedure helps to ensure that the public has a voice in determining how banks will be run. The Banking Law also sets out the conditions under which foreign entities may invest in banks in Afghanistan and establishes how banks operating in Afghanistan must cooperate with foreign regulators.

\section{Key Provisions of the Banking Law}

The Banking Law places Da Afghanistan Bank in charge of enforcement of the law's provisions, and it vests Da Afghanistan Bank with the power to promulgate regulations related to banks and the commercial banking industry. There are a broad range of enforcement measures 
that Da Afghanistan Bank can take against banks that fail to meet their legal requirements.

The Banking Law provides detailed requirements that must be met by all banks operating in Afghanistan. It establishes the specific registration, licensing, and permit procedures that all banks must meet. It also creates procedures for newly established and existing companies to follow in order to receive the necessary authorization to operate in the banking industry and delineates the standards that those companies must meet in order to operate legally. In the event that a bank does not comply with the law, procedures are established for the revocation of banking licenses and permits, including a requirement that the decision leading to such revocation be published. This provides banks with greater assurance that a banking license will only be revoked because of a violation of the law.

Organization, ownership, and administration of banks are important areas that the Banking Law covers. The law specifies how the bank entity must be structured, including what organizational documents, such as charters and bylaws, are required. These documents determine the internal rules under which the bank will operate. Banks are also required to maintain a certain capital structure to limit the likelihood of insolvency. This means that every bank must at any time be able to show that its assets exceed its liabilities by at least the amount of capital that was invested in the bank by its owners.

The Banking Law also requires that no bank decrease its capital and reserves through a share repurchase or distribution of capital to its owners without the authorization of the central bank. Management of the bank is required to have a certain structure, and a variety of boards and committees are mandated to ensure proper monitoring of bank functions by its management and owners. The ownership and control of a bank is governed by other additional principles, such as the requirement that managers disclose any conflicting commercial interests and that all employees refrain from using any confidential knowledge gained through their work at the bank for personal benefit.

The operation of a bank requires the application of several common banking principles, and the activities a bank is allowed to undertake are limited to protect the interests of the public. Key banking principles include the requirement that banks meet all conditions required by law or by the central bank as a condition of their licensing. Banks also must maintain sufficient capital and liquid assets, keep proper records, and monitor the risk of their business and investments.

Activities that banks are generally allowed to undertake include receiving money deposits; extending credits; buying and selling a variety of financial instruments and commodities; entering into guarantees and letters of credit; providing services related to money, securities, and other financial instruments; money brokering; safekeeping of valuables; and providing financial information. The methods by which banks are allowed to undertake these activities are further regulated by the law and a variety of activities are specifically prohibited to ensure that banks do not undertake activities that will conflict with their activities as banks.

A final key component of the Banking Law establishes a special procedure for bankruptcy that applies exclusively to banks. Essentially, Da Afghanistan Bank has the power under certain conditions to appoint its own manager for a bank that is not fulfilling its legal 
obligations. Since failure of a bank can have severe consequences for the bank's customers. This procedure is designed to allow Da Afghanistan Bank to protect those customers and the economy in Afghanistan in general from the failure of a large or important bank (Banking Law of Afghanistan). Banks are seen as particularly important to the proper functioning of the economy because many businesses rely on banks to finance their operations. If a bank fails and those businesses are unable to obtain credit, then the failure of the bank could cause many of the businesses that the bank serves to go out of business. This principle is illustrated by the recent global financial crisis. The potential for this contagion effect is one of the reasons that special bankruptcy procedures apply to banks.

\section{Discussion Questions}

1. Is there any value in creating a body of commercial laws that is not effectively enforced? Why is it important to have reliable ways to enforce commercial laws?

2. What effect do unclear and inefficient administrative procedures have on the ability of entrepreneurs to establish and run businesses?

3. Are the current informal and customary methods superior to the current formal court system for resolving disputes? Why?

\section{B. Other Laws Governing Loans, Interest, and Bankruptcy}

Although the system used to register land is currently being reformed, it can still be difficult for people and businesses to use land as collateral to guarantee repayment of a loan. A secured transaction law is currently planned and would enable businesses to use a wider range of assets to secure loans. In transition countries such as Albania and Romania, secured transaction laws were introduced along with other reforms and have substantially increased the ability of firms to raise credit to fund their businesses. In addition to the secured transactions law, the Government of Afghanistan is also in the process of drafting a mortgage law. This law has the potential to allow entrepreneurs and companies to more easily obtain funding for the growth of their businesses.

Afghanistan has not yet adopted a bankruptcy law, and the country ranks extremely poorly when compared to other countries with regard to the ability of a business to cease operation. One study ranks it 142nd in the world (World Bank 2005). The Government of Afghanistan is in the process of drafting a bankruptcy law that will create a coherent means of distributing assets when a company becomes insolvent. Adoption of such a law will allow entrepreneurs who are starting businesses to more accurately assess the costs of closing those businesses. The absence of a bankruptcy law (except as applied to banks, as discussed above) currently may serve as a deterrent to entrepreneurs since they cannot be certain how expensive it will be if they are forced to close their businesses. While the Partnership Law and Corporations and Limited Liability Companies Law contain some liquidation provisions that provide a clear procedure for closing a 
business, a bankruptcy law will be of increasing importance as the banking industry becomes more advanced and requires that bank loans receive priority over other creditors when a business is closed.

\section{Discussion Questions}

1. What is the primary purpose of Da Afghanistan Bank? What are its other functions?

2. What are some potential conflicts between Da Afghanistan Bank's mission of controlling inflation and supporting government policy?

3. How do the activities of banks drive economic growth in other industries?

4. Why do you think banks are regulated differently from other industries? Why might bank failure be particularly dangerous to the broader economy?

5. How can the ability to guarantee a loan using the assets of the borrower create economic growth?

\section{COMMERCIAL LAW ENFORCEMENT AND THE COMMERCIAL COURTS OF AFGHANISTAN}

The Commercial Court is the primary formal venue for contract and commercial disputes. Theoretically, a Commercial Court should exist in each province of Afghanistan so that cases related to contract and commercial disputes can be heard in that province. Article 45 of the Law of the Organization and Authority of the Courts provides that a Commercial Court be created in every province. Administratively, the Supreme Court of Afghanistan has divided the provincial Commercial Courts into eight zones. However, only two of the eight zones have functioning Commercial Courts. The Commercial Court in Kabul and those in a few other large cities actively hear cases, but the Commercial Courts in the other provinces are not yet active.

The Commercial Court is also likely to hear cases that deal with commercial property leases. However, courts of general jurisdiction handle cases dealing with other property issues or transactions, such as title transfers and mortgages. It is also possible that commercial disputes might be referred to other courts as criminal cases.

The Commercial Court was part of an executive agency until the 1964 Constitution established the court as part of the judiciary. The Commercial Court is not specifically mentioned in the 2004 Constitution. However, no other special courts are mentioned either, and Articles 116, 122, and 123, when read in conjunction, seem to permit the existence of a Commercial Court as a subordinate court to the Supreme Court of Afghanistan.

Under the 1964 Constitution, the Commercial Court had a great deal of authority and autonomy. The Commercial Court Procedure Law passed under the 1964 Constitution granted 
the Commercial Court the power to oversee settlement upon agreement of the parties; to make preliminary rulings; to initiate suits, motions, and pleadings; and to conduct trials, hear evidence, make decisions, and hear appeals. The Commercial Court was also authorized to make arbitration award rulings. The law limited the role of the Supreme Court to making rulings related to court fees and a few other issues in cases under the jurisdiction of the Commercial Court.

The fact that the Commercial Court lacks constitutional authority under the 2004 Constitution limits the court's ability to serve as an independent forum for business disputes, although this is not uncommon in other legal systems. Article 95 of the 2004 Constitution gives the Supreme Court of Afghanistan control over all regulation of the judiciary. Therefore, the Supreme Court now retains ultimate jurisdiction over the Commercial Court, so it is up to the Supreme Court to set priorities for the establishment of effective Commercial Courts in all provinces of Afghanistan.

\section{A. Issues Related to Transformation of the Commercial Courts}

The Commercial Courts of Afghanistan have several problems that must be addressed if they are to play an important and effective role in the Afghan legal system. Judicial decisions need to be made public and readily accessible so that they are subject to public scrutiny and so that legal outcomes become more predictable.

Additionally, the facilities and staffs of the existing Commercial Courts need to be improved, and new Commercial Courts need to be established. Courts lack bailiffs and recorders, and many judges have not received training in the complex commercial transactions and disputes on which they must make rulings. Some steps have been taken toward the creation of a judicial training program that will prepare Commercial Court judges for their duties, and six additional Commercial Courts are being planned for the six administrative zones that currently lack operational courts. Once these courts are functional and begin making rulings that are predictable and transparent, investment in these regions is likely to become much more appealing.

However, funding these courts remains a problem. Creation of the Commercial Court system requires a large investment by the government or foreign donors. Even under the present structure, fees for use of the court's services may pose a substantial deterrent to businesses or individuals who might otherwise utilize the Commercial Court. Currently, the losing party must pay a total of 46 percent of the judgment as a fee for the three stages of Commercial Court litigation, including two appellate stages. A losing plaintiff must pay one percent of the amount of his or her failed claim.

It seems that there would be a greater incentive to use the court if the government were able to make available the necessary funding for the Commercial Court from taxes on commercial activity, particularly since such commercial activity would benefit from the establishment of a reliable and efficient means of commercial dispute resolution. It is unclear whether enough trained judges and funding will be available to fully implement a countrywide 
Commercial Court system. Therefore, in provinces lacking Commercial Courts, cases may continue to be resolved by the Primary Courts or by informal means such as local shuras.

Even in regions where Commercial Courts are established, it is not clear that businesses have come to view them as an efficient forum for resolving disputes. In a 2005 survey, the World Bank found that out of 335 firms surveyed, only three reported that they had used the Commercial Courts to resolve a payment dispute during the past two years. Although the situation seems to have improved in some respects since 2005, it is unclear how much faith businesses have in the Commercial Courts at this time.

Efficiency is also an enduring challenge. Of the three firms that reported using the Commercial Courts, it took an average of 34 weeks for the cases to be decided, and only one of the firms was satisfied that the decision in the case was properly enforced.

Given the problems of the Commercial Courts, it is unsurprising that some studies indicate that as much as 80 percent of disputes are settled by means of the shura or other informal systems. Although informal settlements are common in many countries due to the cost of court proceedings, the problem with informal mechanisms in Afghanistan is that shura rulings often contradict the 2004 Constitution and other Afghan laws-and they may not even follow the principles of Islamic law-because the elders who compose shuras are sometimes unfamiliar with codified Afghanistan law or Islamic jurisprudence. Another problem with shura decisions is that powerful local leaders often have great influence on shuras. Therefore a decision may not be entirely based on the law or even notions of fairness and justice. This makes it impossible for businesses to anticipate how a shura will rule on a dispute, thus they are much less likely to make business investments.

\section{Discussion Questions}

1. What is the purpose of taxation? What characteristics should a good tax exhibit? Why do you think each of these characteristics is important?

2. Should tax rates be the same in all regions of the country? Do you think a farmer in Ghor province should pay the same percentage of his income in taxes as a person in Kabul? Why or why not?

\section{TAXATION AND CUSTOMS REGULATION}

\section{A. The Goals of Taxation}

Governments are responsible for providing goods and services to their citizens. Governments that have the ability to raise funds provide police, healthcare, sanitation, and a variety of other services. Taxes are generally the method governments use to collect the funds necessary to provide citizens with goods and services. Until a government can effectively collect 
taxes, it is unlikely it will be able to provide for its citizens. Many people do not want to pay taxes, but those people also generally desire the government to provide them with a variety of benefits.

There are several characteristics that a tax should exhibit to work in the interest of citizens, but evaluating these characteristics can be quite difficult. First, taxes should be efficiently collected. If the amount the government spends to collect the tax is the same or greater than the amount that it succeeds in collecting, then the taxation mechanism is inefficient. Similarly, there is the question of substantive efficiency: How should we determine what should be taxed? Should income be taxed, or should consumption be taxed through sales or excise taxes? Should cars be taxed because they pollute the environment, or should food be taxed because such taxes are easier to collect and will raise more revenue for the government? These can be difficult political questions since each type of tax has the potential to affect the work and spending habits of different economic classes in different ways.

Second, taxpayers must know that their taxes are going to serve a legitimate purpose; even if they do not agree with the exact way in which the taxes will be spent, they must at least know their taxes are not being taken by corrupt officials. But more importantly, they expect to receive services from their government in exchange for the taxes that they pay.

Finally, there should be clear and accessible rules that inform citizens when they must pay taxes and how much they must pay. Uncertainty about the potential tax burdens can have a deterrent effect on investment since investors will be less willing to provide capital to a new business if they think their profits will be reduced by high taxes. Another controversial issue is how much tax individuals should pay relative to one another. Should all individuals pay the same amount in tax, or should wealthier individuals pay more?

\section{B. Individual and Corporate Taxation}

The Tax Law of 2005 was approved by the Council of Ministers and subsequently endorsed by the President of Afghanistan on 14 November, 2005. The law also became effective from that date. The Tax Law of 2005 was adopted in accordance with the 2004 Constitution.

Article 42 of the 2004 Constitution of Afghanistan provides:

- Every Afghan is obligated to pay taxes and duties to the government in accordance with the provisions of law.

- No taxes or duties are enforced without the provisions of law.

- The rate of taxes and duties and the method of payment are determined by law on the basis of observing social justice.

- This provision is also applied to foreign individuals and agencies.

- Every kind of tax, duties, and income collected shall be delivered to the State account. 
An Income Tax Manual has been issued under the authority granted to the Ministry of Finance by Article 113(2) of the Income Tax Law of 2005. The Income Tax Manual is an official source of guidance to the Afghanistan Revenue Department and others regarding the interpretation and application of the Income Tax Law of 2005.

\section{Domestic Tax Administration and Collection}

Domestic taxation for the central government is collected in provincial Mustofiats and district offices. The General Presidency of Revenue in Kabul is the national headquarters and coordinates provincial operations.

Currently, the flow of domestic taxation to the central government is subject to uncertain provincial influences that affect the amount received by the central government and the timing of receipts. The provincial Mustofiats and district offices have very low levels of physical infrastructure, with little office equipment and damaged buildings. Some even lack electricity. As these administrative conditions improve, government revenue from taxation is expected to improve.

\section{Customs Laws and Regulations}

Pursuant to Article 42 of the 2004 Constitution, a Customs Code was enacted to allow for the collection of state revenues by the national customs authorities. It also provides for the organization of a customs service, defines the scope of authority of customs officials, provides for the supervision and the control of the movement of goods in and out of Afghanistan, and makes provisions for the enforcement of customs laws.

\section{Customs Administration}

Under Article Two of the Customs Code, the Ministry of Finance is responsible for the collection of customs revenues of the state and for enforcing the provisions of this law and any other relevant customs legislation. The Department of Customs sits within the Ministry of Finance and is comprised of the General Directorate, the Regional Directorates, and the branches of each Regional Directorate. All customs officials are subordinate to and under the supervision of the General Directorate. The General Director of Customs is appointed by the President upon the recommendation of the Minister of Finance.

\section{Current Challenges to Effective Customs Regulation}

The uniformity of customs regulations and procedures continues to suffer from regional variation. Coordination between customs and other government authorities is still being improved, customs officials are being trained, and customs infrastructure is being upgraded. Progress in national standardization and professionalization is critical to national economic development. Currently, traders face unclear procedures at the borders, as well as extra-legal duties and unauthorized bureaucratic obstructions. 
The Government, with the help of foreign assistance providers, has made customs reform a priority. Key reform efforts are underway to establish standardized fees and procedures for incoming goods and a trained corps of professional customs officials. Several steps have been taken to standardize customs practices. In December 2003, the Customs Department introduced a Single Administrative Document system program, based on the European Union customs regime, for five key provinces. The adoption of the Customs Code in 2005 was another important step in the formalization and standardization of the customs regime of Afghanistan. In March 2005, the Automated System for Customs Data (ASYCUDA) was also implemented. Finally, a system of Licensed Customs Brokers is also being designed.

\section{Discussion Questions}

1. What is the purpose of taxation? What characteristics should a good tax exhibit? Why do you think each of these characteristics is important?

2. Should tax rates be the same in all regions of the country? Do you think a farmer in Ghor province should pay the same percentage of his income in taxes as a person in Kabul? Why or why not?

\section{CONCLUSION}

In this chapter we have examined a wide variety of legal concepts and laws that govern the interaction of people in commercial transactions and the commercial market in general. By examining the purposes and functions of each of the areas of law, you have hopefully gained an understanding of some the components necessary to achieve a formal legal system that can promote economic growth and lead to further economic, social, and political development.

Although the Government of Afghanistan has made it a priority to improve the state of commercial law in the country, the substance of the law and its interpretation still pose significant challenges. We encourage you to continue to explore these and other areas of commercial law in greater depth. 


\section{Glossary}

Assets

Assignment

Consideration

Default Rules

Detrimental Reliance

Equitable Remedy

Fiduciary Relationship

Insolvent the entire property of a person, association, corporation, or estate applicable or subject to the payment of debts

when a party to a contract transfers the benefits of the contract to another party

an essential element of a contract meaning that no party should enter into a binding agreement from which they will receive nothing

terms that are implied to be part of every contract unless a provision of the contract explicitly specifies a different term will be used

when a person relies on another individual's promise to do something; detrimental reliance can sometimes mean that the individual will be forced to carry out his promise, even if it does not meet the requirements of a contract

a type of award, usually something other than money, that is intended to satisfy an injured party when other remedies proscribed by law prove inadequate.

when two people enter into an agency relationship where an agent will act on behalf of the principal, and the actions of an agent can create a binding obligation on the principal

(1) unable to pay debts as they fall due in the usual course of business; (2) having liabilities in excess of a reasonable market value of assets held 


\section{Sources Consulted}

Afghan Law Handbook on Contract Law.

http://www.aisa.org.af/laws/Foreword/Editor'spercent20Publicationspercent20onpercent 20Afghanpercent20Law/Handbookpercent20onpercent20Contractpercent20Lawpercent2 0(2006)/Afghanistanpercent20Countrypercent20Handbook,percent20Contracts.doc.

Allen, William and Reinier Kraakman. 2003. Commentaries and Cases on the Law of Business Organization.

American Law Institute. 2006. Restatement of the Law, Third, Agency (2006).

Arsala, Hedayat Amin. 2007. Afghanistan's Economy - The Government's Plan: Building a New Afghanistan.

Asian Development Bank. Asian Development Outlook 2006: Afghanistan. http://www.adb.org/documents/books/ADO/2006/afg.asp.

Barnett, Randy. 1992. "The Sound of Silence: Default Rules and Contractual Consent." Va.L.Rev. 821 (78).

Carper, Donald, John A. McKinsey, and Bill W. West. 2007. Understanding the Law.

Chirelstein, Marvin. 2001. Concepts and Case Analysis in the Law of Contracts Fourth Edition.

Commercial Arbitration Law of Afghanistan. http://www.commerce.gov.af/fourpercent20laws/ARBITRATIONpercent20LAW.pdf.

Commercial Mediation Law of Afghanistan. http://www.commerce.gov.af/fourpercent20laws/MEDIATIONpercent20LAW.pdf.

Customs Code of Afghanistan. http://www.customs.gov.af/Custom-Codes/code.asp.

Da Afghanistan Bank Law. Available at http://www.centralbank.gov.af/pdf/7Latestpercent20approvedpercent20DABpercent20la wpercent20Englishpercent20verpercent20percent20Dec.pdf

Davis, James E. and Phyllis Maxey Fernlund. 2002. Civics: Participating in Government.

Development Gateway interview with Suliman Fatimie, General Manager for Investment AISA. http://topics.developmentgateway.org/afghanistan/rc/filedownload.do?itemId=1006960.

Easterbrook, Frank and Daniel Fischel. 1985. "Limited Liability and the Corporation." University of Chicago Law Review 52.

Hames, Joanne Banker and Yvonne Ekern. 2005. Introduction to Law Third Edition.

Income Tax Law of Afghanistan. http://www.mof.gov.af/english/tax-information.htm.

Kraakman, Reinier et al. 2004. The Anatomy of Corporate Law.

Law of Banking in Afghanistan. Available at: http://www.centralbank.gov.af/pdf/6Bankingpercent20Lawpercent20_englishpercent20V ersion_percent20Final_Dec_.pdf.

McKechnie, Alastair. 2007. Rebuilding a Robust Afghan Economy: Building a New Afghanistan. Mechem, Floyd R. 1914. A Treatise on the Law of Agency.

Private Investment Law of Afghanistan. http://www.commerce.gov.af/pdf/Privatepercent20Investmentpercent20Law.pdf

Restatement of the Law (Second) Contracts §1, American Law Institute (1981).

Supreme Court of Afghanistan. 2006. Strategy of the Judiciary of the Islamic Republic of Afghanistan. http://iojt3conference.net/docs/ponencia29.pdf.

World Bank. 2005. The Investment Climate in Afghanistan. http://www.aisa.org.af/Downloads/reports/Afghanistanpercent20ICA-Officialpercent20 Draft.pdf. 


\section{CHAPTER 6: CRIMINAL LAW}

\section{INTRODUCTION}

Criminal law is not only one of the most important areas of law, it is also one of the most interesting to study. People-even those with very little interest in legal matters-are naturally drawn to criminal law. It examines some of life's most basic questions-questions of right and wrong, guilt and innocence, crime and punishment, and above all, justice.

Criminal law is also complex. For example, imagine that two farmers conspire to steal livestock from a neighbor. They make a plan for one farmer to distract the neighbor, while the other takes the animals. The men carry out their plan, and are later caught. Should the two men receive the same punishment? If the men decide at the last second not to take the animals, should they be punished? What if the men mistakenly believe the animals actually belong to them? In this chapter you will learn how criminal law attempts to answer these and other difficult questions.

The chapter will begin with a discussion of customary law and codified law, and a brief history of criminal law in Afghanistan. This history will be followed by a description of the criminal justice system in Afghanistan today, with specific focus on the roles of important institutional actors, including the police, prosecutors, defense attorneys, the judiciary, and the Ministry of Justice.

After establishing this framework, we will investigate the basics of criminal law. What is a crime? When is someone guilty of committing a crime? How can different crimes be classified? This section will introduce core concepts such as mental state, causation and attempt, group criminality, and justification and excuse.

Following this, we will examine the treatment of the criminal. Should criminals be punished? Why? How much punishment is too little? Too much? When can we truly say justice has been served? This section will consider these and other questions concerning the theories of punishment, forms of punishment, and the importance of reparation and social harmony.

The next two sections will then examine the nuts and bolts of the criminal law of Afghanistan: criminal procedure and criminal statutes. The section on Afghanistan's criminal procedure will include a look at arrest, detention, and the adjudication process, while the section on statutes will briefly describe a few of the most important substantive criminal laws.

Finally, this chapter will conclude with a look at some of the challenges facing the criminal justice system of Afghanistan. The criminal justice system, like other areas of law, is in a state of transformation. To successfully navigate this changing system, lawyers must understand what the system is doing well, what it can do better, and where future problems are likely to arise. 
While this chapter attempts to be as immediately useful as possible, some sections will adopt more of a forward-looking approach. That is, because different sectors of Afghanistan's criminal justice system are in different stages of development, sometimes this chapter will anticipate transitions that may be months-or years-from taking place. These sections will be clearly noted, however, and will reflect likely reforms based on the law of Afghanistan as currently written, rather than mere suggestions of the authors.

\section{HISTORY OF CRIMINAL LAW IN AFGHANISTAN}

To study criminal law today, it is important to understand the historical roots of crime and punishment in Afghanistan. To that end, this section will begin by briefly examining the history of codified criminal law in Afghanistan.

While certain statutes relating to criminal justice were enacted as early as the 1930 s, it was not until the 1960s that the government made a serious move toward codifying criminal law as part of the general program of codification described in Chapter I.

In 1965, a comprehensive criminal procedure code was adopted-a major step towards the standardization of the criminal justice system. The 1965 code covered all aspects of criminal investigation and adjudication: investigation, detention, interrogation, search and seizure, evidence gathering and prosecution, the treatment of witnesses and the use of experts, and the right to appeal. Other significant developments in the late 1960s included further substantive criminal law statutes (e.g., the 1967 Law on the Prevention of Hoarding) and institutional reforms (e.g., the 1967 Law of Saranwali).

The next major development in the codification of criminal law in Afghanistan came in 1976, when the country's first penal code was approved. The Penal Code-published in Official Gazette No. 347-is an extensive document containing eight sections and 523 articles. For the first time, one unified document defined offenses and regularized punishments in all categories of crime except military law and crimes for which Islamic law provided specific punishment (i.e., hudud, qisas, and diat crimes). From a codification perspective, the adoption of the Penal Code was perhaps the most important development in criminal law in Afghanistan, and much of the Penal Code is still in use today.

Finally, following the 2001 removal of the Taliban, Afghanistan began a new era of codification. Recent reforms in both criminal procedure and substantive criminal law have been codified through such documents as the 2004 Interim Criminal Procedure Code, the 2004 Law on the Campaign against Financing Terrorism, and the 2006 Counter-Narcotics Law. These recent developments form the foundation of codified criminal law in Afghanistan today, and will be examined in later sections of this chapter. 


\section{Discussion Questions}

1. What are some advantages and disadvantages of customary law? Of codified law?

2. Over the last hundred years, Afghanistan has officially moved towards codification, but customary law still governs the daily lives of most people in Afghanistan. Why? Will this ever change? What are the dangers of the laws in practice being different from those on the books?

\section{CRIMINAL LAW BASICS}

You are familiar with the institutions that run Afghanistan's criminal justice system from earlier chapters. Now it is time to begin our study of the criminal justice system itself. To that end, this section will introduce the basic principles of criminal law in Afghanistan. These principles are the foundation upon which the criminal justice system is built.

The first part of this section examines two basic assumptions of the criminal justice system: 1) the presumption of innocence; and 2) the principle of legality. The next section will introduce a set of ideas and rules that determine when an individual is criminally liable for his offensive conduct. These rules are often called the principles of liability. Finally, the third part of this section will explore the classification of crimes.

\section{A. Foundational Principles}

\section{The Presumption of Innocence}

First, let us consider the following scenario. Suppose you have just finished your last exam of the semester when the president of your university calls you into his office. He tells you that another student-who he cannot name-has accused you of cheating on your exam. The president admits that other than the tip of the anonymous student, he has no other proof you cheated. He tells you that unless you can prove you did not cheat, you will fail the exam and be expelled from the university immediately. Is the president's reaction fair?

Now imagine another scenario. You are driving near campus when a police officer stops you and begins to question you. The officer explains that a house in the neighborhood was burglarized, and you match the description of the suspect. After spending a few nights in the local jail, you are taken before a judge. The judge tells you that because you match an eyewitness description of the burglar, you will be found guilty of the crime unless you can prove you did not burglarize the house in question. Is the judge's decision fair?

For those who believe the president and the judge are acting unfairly, you already have a sense of one of the most important assumptions of criminal law in Afghanistan: the presumption of innocence. Article 25 of the Constitution states: "Innocence is the original state. The accused shall be innocent until proven guilty by the order of an authoritative court." 
What does it mean to say innocence is the original state? Essentially, this indicates that under the law, we are all presumed to be innocent. Further, unless someone proves our guilt in a court of law, we will remain innocent and unpunished. If a prosecutor accuses someone of a crime but is unable to prove to a judge that she committed the crime, she must be set free, even if she is unable to prove she is innocent. Consequently, we say that the burden of proof rests with the prosecutor.

\section{Discussion Questions}

1. Why does criminal law in Afghanistan contain a presumption of innocence? What are the moral reasons? The practical reasons?

2. It is often said that it is better for ten guilty persons to escape than for one innocent person to suffer. Do you agree? Why or why not? What about one hundred guilty persons? One thousand?

3. Under the law of Afghanistan, the police can detain and interrogate those suspected of certain crimes before they ever see a judge. Does this power contradict the presumption of innocence? Why or why not?

\section{The Principle of Legality}

The principle of legality requires all laws to be clear, publicly accessible, and prohibits retroactive increases in punishment. Said another way, the principle requires police, prosecutors, and judges to resolve disputes by applying legal rules declared beforehand. In the context of criminal law, the principle of legality asserts that no defendant should be punished for conduct not proscribed by law at the time the defendant engaged in that conduct. More simply put, no one should be punished for doing something that was not illegal at the time she did it.

Further, the principle of legality's ban on retroactivity applies in cases where the state attempts to increase the punishment for a certain crime after the fact. While the government is fully within its right to increase the sentence for a crime (assuming the punishment is not excessive), any new sentence cannot apply to those who committed a crime before the punishment was increased by law. The principle of legality's general ban on retroactivity does not, however, forbid the government from retroactively decreasing punishment.

The principle of legality is specifically embodied in Article 27 of the Constitution. Article 27 states: "No deed shall be considered a crime unless ruled by a law promulgated prior to commitment of the offense." It goes on to state, "No one shall be punished without the decision of an authoritative court taken in accordance with provisions of the law, promulgated prior to commitment of the offense." 


\section{Discussion Questions}

1. Imagine that Faisal commits a theft on Monday. On Tuesday, a new law is passed raising the punishment for theft from one year in prison to two years in prison. Faisal is caught and convicted on Wednesday. What should his punishment be? What if the new law lowered the punishment for theft from one year to six months?

2. The principle of legality requires that the law be "clear and ascertainable." How specific should criminal statutes be?

\section{B. Principles of Liability}

What is a crime? While it is easy to list examples of crimes-theft, burglary, murder, bribery, etc.- -it is more difficult to generalize the conditions that must be met before a defendant can be convicted of a crime (i.e., held criminally liable for a crime). For example, if a speeding taxi driver kills a pedestrian, is the driver criminally liable? Does it matter whether the driver meant to strike the pedestrian? Does your answer change if the driver was speeding to get an injured police officer to a hospital for a lifesaving operation? Or if a bandit was holding a gun to the driver's head and ordering him to drive as fast as possible? What if the impact only broke the pedestrian's leg, but she died eighteen months later from an infection because the leg never healed properly? In these circumstances, is the driver blameworthy?

Criminal law in Afghanistan attempts to answer these questions by applying certain principles of liability. This section will briefly explore five such principles: 1) the concept of material elements of a crime; 2) the concept of mental elements of a crime; 3) the principle of concurrence; 4) the principles of causation; and 5) and the principles of group criminality.

The goal of this section is not to make students experts in criminal liability, but rather to introduce certain fundamental theories. Remember, while the basic ideas are simple, each of these principles is astoundingly intricate.

\section{Discussion Questions}

1. How is criminal liability related to culpability, responsibility, and blameworthiness? How does criminal liability reflect—or influence_the morals of a society?

2. Is there a distinction between "not guilty" (i.e., not criminally liable) and "innocent"? If so, should the criminal justice system be concerned with the difference?

\section{Introduction to Elements of Crimes}

Generally, crimes consist of a number of parts, called elements, all of which must be proven for a defendant to be convicted of that crime. For example, Article 401 of the Penal Code states: "A person who conceals or buries the body of a murdered person, cognizant of the case of 
murder and without informing concerned authorities... shall be sentenced to short imprisonment ...." Thus, for someone to be convicted of the crime of concealment of the body of the murdered, the following four elements must be proven by the prosecutor: 1) the defendant concealed or buried a body; 2) the body was that of a murdered person; 3) the defendant was cognizant of the murder; and 4) the defendant did not inform the authorities. If the prosecutor fails to prove any one of these elements - even if he proves the other three - the defendant must be acquitted (i.e., found innocent and set free).

Under Chapter Two of the Penal Code, the elements of an offense are classified as the material element, the mental, and the legal element. The material element concerns the defendant's acts or omissions, the mental element concerns the defendant's knowledge or intent, and the legal element concerns the codified description of a criminal act and its punishment under the law.

The next sections explore the material and mental elements of crimes. The legal elements - the substantive descriptions of particular offenses - are too numerous to be listed in this chapter. A later section on criminal law statutes, however, will introduce many of the statutes where these descriptions can be found.

\section{Material Offense Elements}

The material elements of a crime are those acts or omissions, taken together, that result in illegal behavior. In other words, they describe things that individuals are not supposed to do. This conduct can be either affirmative actions (acts) or failure to take action when the law imposes a duty to act (omissions). "Acts" are rather straightforward, but the concept of "omissions" may seem somewhat counterintuitive at first. How can someone be convicted of a crime for not doing something? Let's look at an example.

Asad is awoken in the middle of the night by screams from his neighbor's house. He runs outside, and finds that his neighbor's house is on fire. Rather than helping his neighbor contain the fire, however, Asad merely watches. Soon, a police officer arrives and begins fighting the fire. He shouts to Asad for help, but Asad continues to stand and watch. Under Article 354 of the Penal Code, Asad may be charged with the crime of failure to render assistance. Article 354 states: "A person who, at the time of fire or some other big incident, refuses to assist without proper excuse and in-spite of the request of an official of public services, shall be sentenced to short imprisonment ...."

The material elements of a crime- the elements that collectively form the act or omission in question-are sometimes referred to as the objective offense elements because they refer to a state of affairs, or facts, that exist independently of how they might be perceived by someone. That is, whether Asad did assist or did not assist is a fact. It does not depend on the police officer's perception, Asad's perception, the neighbor's perception, or anyone else's perception of the situation. 


\section{The Mental Element}

While material offense elements concern what a defendant did or did not do, the mental element concerns the defendant's knowledge and intent. Why is intent important? Why is it unacceptable to punish someone for their behavior regardless of their intentions? One simple explanation is that society may not want to punish an individual for the unintended consequences of his actions (or may not want to punish him as harshly as someone who achieved the same ends on purpose). This rationale is evident in the Penal Code. Articles 34, 35, and 36, for example, distinguish intentional crime (in which the defendant's criminal intention is realized), from unintentional crime (which is brought about by a mistake). Further, in many cases the Code prescribes different punishments for intentional offenses and unintentional offenses, even though the results may be the same. Article 367, for example, states: "a person who deliberately creates a flood ... shall be sentenced ... to long imprisonment, while Article 368 states: "a person who creates a flood by mistake ... shall be sentenced to medium imprisonment ...."

When a crime contains a mental element-such as the words "intentionally," "knowingly," "deliberately," "cognizant of," etc.- the prosecutor must prove that element in order for a court to find the defendant guilty. Different crimes may have different mental elements, so it is important to consult the specific statute to determine what, exactly, the prosecutor must prove.

Because the Penal Code is not instructive on how to interpret different levels of intent, it may be useful to engage in a comparative analysis of another legal system. For example, the American Model Penal Code identifies four levels of culpability, based on the mental state of the defendant. The levels of culpability are, in order from most culpable to least culpable: 1) purpose; 2) knowledge; 3) recklessness; and 4) negligence. The following table takes a closer look at what each level of culpability means in plain language:

\section{Levels of Intent}

- A person acted purposely when he hurt someone intentionally.

- A person acted knowingly when he didn't want to hurt someone, but he knew (or was reasonably certain) that he would hurt someone.

- A person acted recklessly when he didn't want to hurt someone, but he knew the odds of hurting someone were very high, and someone got hurt.

- A person acted negligently when he didn't mean to hurt anyone, and he didn't even know the odds of hurting someone were high, but he should have known the odds of hurting someone were high, and someone got hurt (Samaha 2004: 89).

In the United States, for example, prosecutors are typically required to prove one of these four mental states for each material element of a crime.

The approach taken by the Model Penal Code is not the only way to classify mental elements, but it is a system that may help you think about the range of culpability and how the criminal justice system should attempt to match punishment to intent. 
Finally, a certain class of crimes called strict liability offenses do not require the prosecutor to prove the defendant's mental state. To convict a defendant of a strict liability crime, it is enough for the prosecutor to show that the defendant is responsible for the proscribed act or omission (i.e., prove the material offense elements). In other words, for this set of crimes it does not matter if the offender acted intentionally or made a mistake, he will be held criminally liable either way.

Generally, due process requires that strict liability only apply to the least serious crimes. In the United States, for example, many minor traffic violations are considered strict liability offenses.

\section{Discussion Questions}

1. If someone breaks a law by mistake, and she was not acting recklessly or negligently in any way, should she be punished? Why?

2. What is the rationale behind strict liability? What type of crimes do you think should be classified as strict liability crimes?

\section{Concurrence}

Now that you are familiar with objective and subjective offense elements, consider the following scenario. Jamaal and his brother own a shop. The shop is having problems with rodent infestations, so Jamaal places poisoned food in the storeroom, hoping to kill the rodents. He immediately tells his brother what he has done, and warns his brother to stay away from the poisoned food. The next day Jamaal and his brother get into an argument. Jamaal becomes extremely angry, and tells his brother "I wish you would die!" as he storms out of the shop. That evening, forgetting Jamaal's warning, the brother eats the poisoned food and dies. Is Jamaal guilty of murder?

If we think about material and mental offense elements, it seems that Jamaal should be held criminally liable. He poisoned the food that killed his brother (material element) and he clearly stated that he wanted his brother to die (mental element). A simple case of murder, right? Wrong.

According to the principle of concurrence, Jamaal is not criminally liable for his brother's death. The principle of concurrence states that in order for a person to be held criminally liable, the mental element must trigger the material element, or the elements must occur at the same time. Thus, because it was not Jamaal's intent to kill his brother when he placed the poisoned food, it is irrelevant that he later said he wanted his brother to die. He did not desire to kill his brother when he poisoned the food, nor did his desire to kill his brother lead to his poisoning of the food. The mental element did not trigger the material element, nor did the elements happen at the same time. As a result, Jamaal should not be held criminally liable for his brother's death.

\section{Causation}


Imagine a scenario in which Rajibullah is upset with his brother and stabs him in the hand with a kitchen knife. The wound is not critical, but serious enough to require treatment. An ambulance is called and picks up the brother to take him to the hospital. On the way to the hospital, however, the ambulance is involved in a car accident, killing everyone on board. Is Rajibullah liable for his brother's death?

The principle of causation deals with the connection between conduct and harm. Under the principle of causation, in order for Rajibullah to be criminally liable for his brother's death, a prosecutor must show that Rajibullah stabbing the brother in the hand (conduct) caused the brother's death (harm).

To comply with the principle of causation, the prosecutor must satisfy two inquiries: 1) whether Rajibullah's actions were the actual cause of his brother's death; and 2) whether Rajibullah's actions were the legal cause of his brother's death?

Actual cause is more easily determined than legal cause because it is a factual inquiry rather than an interpretive standard. That is, to show actual cause, the prosecutor must simply show that if Rajibullah had not stabbed his brother, the brother would not be dead. For this reason, actual cause is sometimes called "but for" cause. In other words, the question being asked is: but for Rajibullah's actions, would his brother be dead?

Legal cause, on the other hand, is a more difficult concept. Called proximate cause in some jurisdictions, legal cause asks whether it is legally fair to hold Rajibullah responsible for his brother's death. In most cases the legal cause inquiry is rather straightforward. Sometimes, however, it can get complicated. Complex cases usually arise due to the existence of an intervening cause - any event that happens between the conduct and the harm that contributed to the harm. For example, in the case of Rajibullah and his brother, the ambulance getting into an accident on the way to the hospital is an intervening cause. It is something that happened between Rajibullah stabbing his brother and his brother's death, and it contributed to the death.

The mere existence of an intervening cause, however, is not enough to determine legal cause. Rather, it is necessary to consider the nature of the intervening cause.

For example, imagine that when Rajibullah stabs his brother, his brother runs away, falls down a staircase, and dies as a result of the fall. The brother's fall is called a responsive intervening act because it was a response to Rajibullah's triggering act. In other words, the brother fell down the stairs because he was trying to escape from Rajibullah. Compare this to a scenario in which Rajibullah stabs his brother in the hand, and then the brother runs outside where he is struck by lightning and killed. This type of intervening act is known as a coincidental intervening act because there is no causal connection between Rajibullah's conduct and the intervening act. Rajibullah stabbing his brother did not cause his brother to be struck by lightning. His brother was simply in the wrong place at the wrong time.

While there is no hard rule for determining legal cause, courts will generally be more likely to find legal cause where there is no intervening cause, or where the intervening cause is a responsive act. In the event of a coincidental intervening act, the court will often find that the 
coincidence interrupted legal causation and therefore the accused is not criminally liable. In other words, it is just too difficult for the court to determine the real cause of the brother's death: the stab wound or the accident. Therefore, the court would not hold Rajibullah liable for his brother's death, only for stabbing him in the hand.

\section{A. Responsive Intervening Act

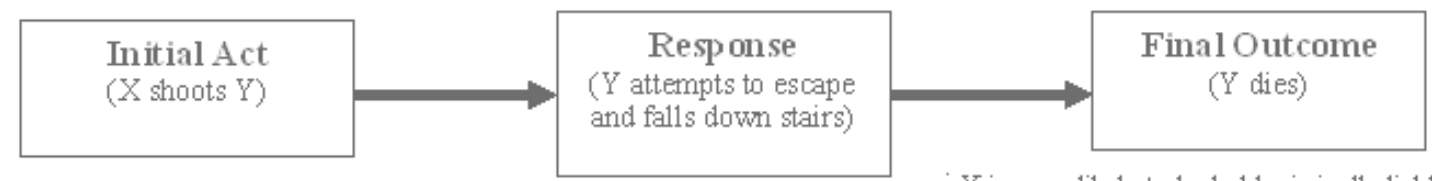 \\ $\mathrm{X}$ is more likely to be held criminally liable for final outcome}

\section{B. Coincidental Intervening Act}

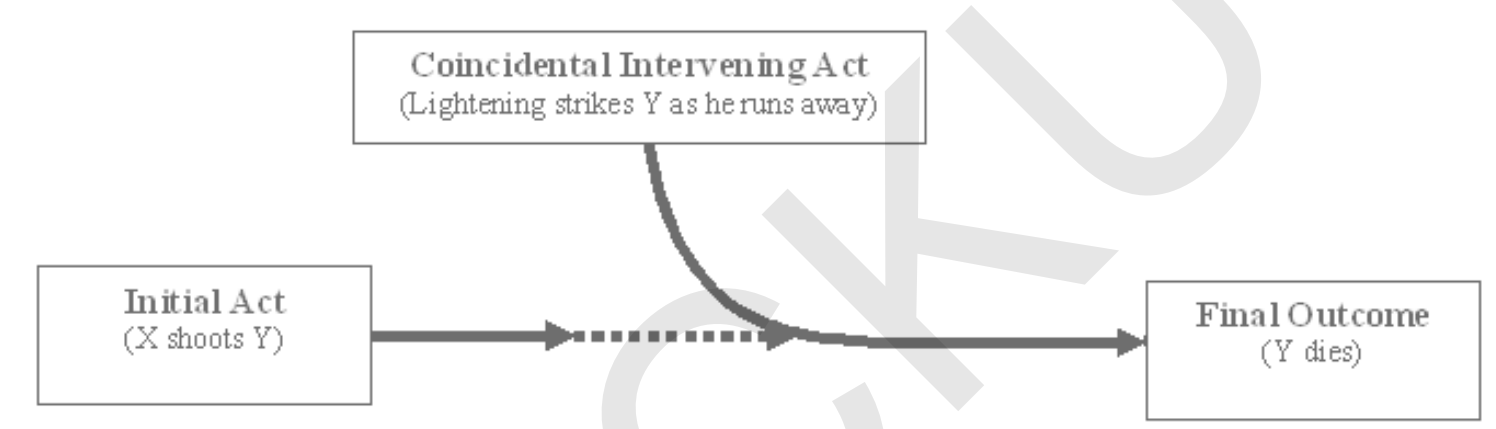

$\mathrm{X}$ is less likely to be held criminally liable for final outcome

\section{Discussion Questions}

1. What is the rationale for having two causation inquiries? Why would it be insufficient to only have an inquiry for legal cause?

2. What is the relationship between causation and concurrence?

\section{$\underline{\text { Attempt }}$}

Imagine a man decides to kill his neighbor to take the neighbor's land. The man buys a gun and bullets, and goes out looking for his neighbor. When he finds the neighbor, he says, "I am going to kill you so that I may take your land," points the gun at the neighbor, and pulls the trigger. But the gun misfires and the neighbor escapes. Should the man be punished for murder?

The law of attempt deals with crimes absent a harm. That is, the law of attempt becomes relevant when the defendant has not managed to satisfy the material element of an offense. For example, in the hypothetical above the man has not killed anyone, and therefore has not satisfied 
the material element for homicide. The question is whether he should be punished for trying, and whether he should be punished as harshly as he would have been if he had succeeded.

Articles 29-33 of the Penal Code answer these questions. According to Article 29, "initiation of a crime is the starting of an act with the intention of committing a felony or misdemeanor, but whose effects have been stopped or offset by reasons beyond the will of the doer." Articles 30, 31, and 32 set out the punishment for attempts at felonies, misdemeanors, and obscenities, respectively. In general, the punishment for attempt is half the maximum punishment of the crime itself. Thus, if the maximum punishment for an offense is ten years in prison, someone who attempts that offense but fails to cause the requisite harm will be punished by five years in prison.

One of the most difficult situations in criminal law is determining exactly when a person's actions become an attempt. For example, in the hypothetical above, if the man had told his wife he planned to kill the neighbor, and the police found out about the plan, is the existence of the plan enough to convict the man of attempted murder? What if he had already purchased a gun and bullets? What if he had already purchased a gun and bullets and is apprehended on the way to his neighbor's house?

Article 29(2) of the Code declares, ". . . the decision to commit a crime or performance of preliminary works is not considered the initiation of a crime." The key question, then, is what separates "performance of preliminary works" from an attempt? Legal scholars in many jurisdictions have addressed similar issues, and there no consensus on the matter. Generally, it is safe to say that the closer a person is to completing a crime, the closer that person is to an attempt. In the end, however, the question becomes one of common sense for the court to decide.

\section{Introduction to Alliance and Association}

Until this point, we have been considering the question of when an individual should be held criminally liable for his own conduct. This section will shift gears and consider the question of when several persons should be held criminally liable for conduct they commit or plan together. To address these situations, we must explore the concepts of association and alliance.

Why are association and alliance important? At the beginning of this chapter we considered a hypothetical concerning two farmers who made a plan to steal livestock from a neighbor. The first man distracted the neighbor while the other took the animals. Are they both criminally liable? Should they receive the same punishment? The answers depend on the law of alliance.

Now consider a slightly different hypothetical involving the same two farmers. This time, rather than forming a criminal plan, the men are simply talking about their neighbor. The first farmer mentions that the neighbor's livestock is the best in the province, and he knows the neighbor does not lock his gate or employ any guards. He further mentions he will be taking the neighbor to dinner next Thursday, so the house will be empty. Next Thursday, while the neighbor is away at dinner, the second farmer steals the livestock. Should both farmers be 
punished? Should they be punished as harshly as if they had both planned and taken part in the theft? This time, the answers depend on the law of association.

\section{Alliance}

Article 49 of the Penal Code defines alliance as "the joining together of two or more persons. . ." in committing a crime, or "joining in equipment, facilities, or supplementary works of the said crimes, provided that the alliance is regular and continual, even if it has taken place at the formation stage of a crime or for a short time." Simply stated, a criminal alliance is an agreement between two or more persons to break the law at some point in the future. As the code says, it does not matter if an agreement only involves the planning of a crime that was never carried out. The members of the alliance-often called conspirators or coconspirators-will be punished nonetheless.

Articles 50 and 51 describe the punishment for an alliance. In the case of an alliance to commit a felony, every conspirator "shall be sentenced to a long imprisonment not exceeding seven years. . .." In the case of an alliance to commit a misdemeanor, every conspirator "shall be sentenced to a prison term of not more than two years, or to a cash fine of not more than 24,000 Afghanis." However, if the purpose of the alliance is to commit a crime whose punishment according to the law is less than the punishment for criminal alliance, the guilty parties "shall be sentenced to one quarter of the maximum punishment fixed for the crime for which the alliance is made."

Finally, Article 52 addresses the dissolution of an alliance. According to Article 52, a conspirator can reduce liability for his role in a criminal alliance by informing the authorities of the alliance before the crime is committed and before the authorities have begun any investigation of their own. The conspirator can fully escape liability if the information he provided leads to the arrest of the other conspirators.

\section{Association}

It can be difficult for beginning criminal law students to distinguish between alliance and association. We have just seen that an alliance is two or more persons planning together to commit a crime, whether or not the crime is committed. On the other hand, according to the Penal Code, association is when an individual assists another in the commission of a crime (i.e., the crime actually occurs). The person who actually commits the crime is called the principal offender, while the person who assists the principal offender is called the accomplice.

According to Article 39, the assistance given by an accomplice can be "knowingly assisting the principal offender in any way with respect to the equipment, facilities, or supplementary works for committing the crime ...." It can also be "entering into an agreement with another person to commit a crime. . " or "instigating a person to commit one of the acts comprising a crime ...." In all cases, however, the crime must take place as a result of the assistance given. 
Article 40 through 48 present the punishment scheme for association. While we will not examine each article individually, the default rule is that an accomplice shall be treated as a principal offender (i.e., given the punishment prescribed by law for the offense he helped commit), unless the law stipulates otherwise.

\section{Discussion Questions}

1. Explain the difference between alliance and association. What is the legal rationale for punishing association more heavily than alliance?

2. Explain the difference between principal offender and accomplice. When does an accomplice become a principal offender? Can there be more than one principal offender?

3. Is it possible for an individual to be both an accomplice to a crime and part of a criminal alliance related to that same crime? If so, what punishment would the individual receive?

\section{Defenses: Justification and Excuse}

Is it ever lawful to engage in conduct generally proscribed by the law? Imagine a forest fire is burning towards a village of 10,000 people. To save the town, Hamid burns a field of crops between the fire and the town to set up a firebreak. In doing so, Hamid has intentionally set fire to someone else's property with the goal of destroying it, thereby satisfying all the elements of the crime of arson. Should Hamid be held criminally liable for his conduct?

Criminal law recognizes that sometimes individuals should not be held criminally liable for their conduct even though the conduct satisfies all the requisite principles of liability. In these circumstances, we say the individual has a valid defense.

For the purposes of this section, we will break the world of defenses into two theoretical categories: justification and excuse. Justification is the idea that the conduct in question is not unlawful, whereas excuse is the idea that the defendant is not criminally liable for his unlawful conduct. Examples of justification and excuse defenses will be explored below.

It is important to note, however, that justification and excuse defenses are not the only defenses available to the accused. The other main category of defense-known as elementnegating defenses-involves some variation of the argument that the prosecutor has not proven all the elements necessary to convict. These defenses can attack either one element of the charged crime, or many elements of the charged crime. Element-negating defenses tend to be more fact-specific than doctrinal, and therefore will not be discussed here in detail.

\section{Justification Defenses: Necessity}

In the earlier hypothetical regarding Hamid burning a field to save a village, your intuition may have been that Hamid should not be held criminally liable because his conduct was necessary to save life and property. If so, you are right— the law recognizes a defense called 
necessity. When an individual successfully presents a necessity defense, there is no criminal liability because the law recognizes, under the circumstances, that the conduct of the accused was not unlawful. Thus, necessity is an example of a justification excuse.

Article 95 of the Penal Code states: "a person who for the sake of saving his own soul or good or the soul or good of someone else comes to face great and immediate danger, such as not to be able to ward it off without committing an act of crime, shall not be considered responsible provided that the person has not deliberately caused the said danger and that the damage to be avoided should be greater than the damage from the act of crime." From this definition, we may conclude that there are four elements to a necessity defense:

First, the defendant must show the harm he sought to avoid outweighed the danger of the prohibited conduct in which he engaged. In our hypothetical, this means Hamid must prove the potential danger of the forest fire reaching the village was greater than the danger of burning the field.

Second, the defendant must show he had no reasonable alternative. If Hamid could have easily extinguished the forest fire by himself, burning the crop would not be justified.

Third, the defendant must show he ceased the prohibited conduct when the danger passed. Thus, if Hamid had continued burning crops long after the forest fire was subdued, his conduct would not be deemed necessary.

Finally, the defendant must show he did not create the danger he sought to avoid. In other words, Hamid would not escape criminal liability for burning the crop to stop the forest fire if he was responsible for starting the forest fire in the first place.

\section{Justification Defenses: Self-Defense}

Self-defense is closely related to necessity, and it may help to think about self-defense as a type of necessity defense. Like necessity, self-defense is a justification, meaning that when conduct is proven to be undertaken in self-defense, the law considers that conduct lawful.

Articles 57 through 64 of the Penal Code discuss self-defense. Article 57 states the proposition: "commitment of a criminal act for the purpose of exercising the legitimate right of defense shall not be considered a crime." Article 59 states: the "legitimate right of defense comes into presence when the defender is assured by rational instruments and logical reasons that a danger of transgression is directed to good, life, or honor of the defender or someone else." It is important to note that the defender may defend both himself and others.

Article 60 sets out the elements of basic self-defense:

1. Defense should be against aggression and assaults;

2. Defense should be proportionate to the danger of the threat;

3. Defense should be the only way of removing the danger;

4. Defense should be concurrent with the attack of the opposite side; 
5. Defense should be against an illegal and unjust act;

6. The defender should not have deliberately caused the criminal action of the opposite side.

Under Article 64, a court has the power to reduce the punishment of someone who, in good faith, used excessive force in defense of himself or another.

\section{Excuse Defenses}

This section will consider four distinct excuse defenses: 1) insanity and mental disease; 2) intoxication; 3) immaturity; and 4) coercion. Unlike justification defenses, recall that in the case of excuse defenses the conduct in question is still considered unlawful. The defendant is excused from criminal liability, however, because of the defendant's status or mental state. Thus, we may say justification is generally concerned with the circumstances of an offense, while excuse is generally concerned with the defendant's ability to form the requisite intent.

\section{Insanity and Mental Disease}

According to Article 67 of the Penal Code, "a person who, while committing a crime, lacks his senses and intelligence due to insanity or other mental diseases has no penal responsibility and shall not be punished."

The rationale behind this rule seems rather straightforward: society does not want to punish a person who has no idea of what he did or why he is being punished. To do so would offend the notion of blameworthiness (i.e., is the person really to blame, or is the illness to blame? Should we punish someone for being ill?). On the other hand, the medical community recognizes different types of mental illness. While two individuals may be diagnosed with mental health disorders, the first may be high-functioning while the second is severely disabled. Is it right, then, to hold them to the same legal standard?

In many jurisdictions, courts rely on the assessments of mental health professionals to determine whether a defendant should be held criminally liable for his unlawful conduct. Often, this assessment will focus on the defendant's cognitive capacity to understand the difference between right and wrong, and his volitional capacity to act according to his understanding of that difference. If either capacity is lacking, the defendant will be found criminally insane and will not be culpable for his unlawful conduct.

It is also worth noting that under Article 44 of the 2004 Interim Rules of Criminal Procedure, if during a criminal trial it appears the accused suffers from a mental illness that prevents him from the possibility of a defense, the court will stay the proceeding (i.e. pause it) and submit the accused to a mental examination. If the examination finds the accused is indeed suffering from a mental illness that prevents him from the possibility of a defense, the court will rule the defendant incompetent to stand trial and the trial will be postponed.

Remember, however, that competency to stand trial is an inquiry into the defendant's mental state at the time of trial. It is a separate inquiry from that which seeks to determine the defendant's mental state at the time he allegedly committed the crime. Thus, while a defendant 
once judged incompetent may recover from his illness and eventually stand trial, a defendant found to be criminally insane when he committed a crime will never be held culpable for that crime.

\section{$\underline{\text { Intoxication }}$}

Intoxication is generally defined as a state in which a person's normal capacity to act or reason is inhibited by alcohol or drugs. Should an individual be held criminally liable for unlawful conduct committed while intoxicated? For many reasons, this strikes us as a more difficult question than the earlier question regarding the insane, even though an intoxicated person may be equally unable to form the intent necessary to be held criminally liable. Perhaps our hesitance stems from the fact that intoxication-whether by alcohol, narcotic substances, prescribed medication, or other means - can be voluntary or involuntary.

Afghan criminal law acknowledges this very distinction. Article 68(1) states: "a person who while committing a crime loses his senses and intelligence due to use of intoxicating or narcotic substances, and if this use is made by force or lack of knowledge, shall not be punished." Article 69(1) adds: "if a person uses intoxicating or narcotic substances at his own will and commits a crime, he shall be considered responsible and it will be assumed that he has committed the crime in a state of full sense and intelligence."

It also bears noting that voluntary intoxication is itself a punishable offense in Afghanistan. Article 349 states: "A person who uses alcoholic or narcotic substances shall be sentenced to imprisonment of three to six months or cash fine of three to six thousand Afghanis, or both punishments, unless otherwise stipulated in the law."

\section{Immaturity}

Remember from the earlier discussion of insanity and mental disease that one of the questions in determining whether an individual should be held criminally liable for his unlawful conduct is whether he knows the difference between right and wrong. Anyone who has spent time with children can attest, it is often unclear whether they appreciate this very difference. Therefore, the Penal Code has included a number of provisions dealing with children, adolescents, and teenagers in the criminal justice system. These provisions were superseded, however, by the enactment of the Juvenile Code in 2005 (published in Official Gazette No. 846).

According to the Juvenile Code, any person who has not reached the age of eighteen is a child, and is to be treated in accordance with the Juvenile Code, rather than the Penal Code. The Juvenile Code recognizes three classes of children: 1) non-discerning children (children under age seven); 2) discerning children (children between ages seven and twelve); and 3) juveniles (children between ages twelve and eighteen).

Under Article 5 of the Juvenile Code, a child who has not reached age twelve cannot be held liable for his criminal conduct. If that child's conduct was the result of negligent parents, however, the parents may be obligated to compensate the victim or victims for any material loss 
caused by the child. Juveniles can be held criminally liable for their actions, but are afforded legal protections above and beyond those offered to adults.

For example, under Article 8 of the Juvenile Code, imprisonment is considered only as a last resort when dealing with a juvenile offender. The law sets a clear preference for rehabilitation and re-education through social services and juvenile rehabilitation centers.

Whenever a juvenile is given a prison sentence, the sentence is considerably less than what would be given to an adult convicted of the same crime. For example, under Article 39 of the Juvenile Code, prison sentences given to juveniles between the ages of twelve and sixteen may not exceed one-third of the maximum punishment prescribed in the Penal Code. Sentences given to those between the ages of sixteen and eighteen may not exceed one half of the Penal Code maximum.

Further, Chapters Two and Three of the Juvenile Code establish separate rules of criminal procedure for cases involving children. These rules are designed to protect children during investigation, arrest, and trial. While we will not examine these rules in detail, remember that if a case involves a child, the relevant procedural rules will be found in the Juvenile Code, rather than the Interim Criminal Procedure Code, which is discussed later in this chapter.

Finally, it is worth noting that under Article 39 of the Juvenile Code, no child can be sentenced to continued (life) imprisonment or death.

\section{Coercion}

Coercion is, in theory, the simplest of the excuse defenses. For example, should an individual be held criminally liable for arson when a terrorist is holding a gun to his head and ordering him to start a fire? It is hard to argue that he should, and the Penal Code recognizes this. Article 94 provides that "a person who commits a crime under the influence of a moral or material force, repulsion of which is not possible otherwise, shall not be considered responsible."

Generally, for a coercion defense to be successful, an individual must prove elements similar to those discussed in the section on necessity. In fact, some legal scholars maintain that the two defenses are essentially equivalent, the only difference being that coercion covers situations where the source of the outside force is the action of another human being (or the result of that action), while necessity covers situations where the outside force is a physical force beyond the actor's control.

Students should be wary of this formulation because it blurs the important theoretical differences between justification and excuse defenses-necessity is usually defined as a justification defense while coercion is defined as an excuse defense-but thinking about it this way may be helpful if you have trouble distinguishing between necessity and coercion. 


\section{Discussion Questions}

1. What is the difference between a justification defense and an excuse defense? Why is the distinction important?

2. Why is coercion classified as an excuse defense rather than a justification defense?

\section{Classifying Crimes}

Legal systems distinguish between serious crimes and lesser crimes for many reasons. Codifying this distinction can help standardize treatment of the guilty, thereby avoiding arbitrary or inconsistent punishment. Formal classification of crimes according to severity can also be helpful in other ways.

For example, when an individual is aware that certain conduct is classified as a serious crime and punished harshly, he knows that society has made a certain moral judgment about that conduct. That is, it is very important to society that individuals be deterred from engaging in that conduct. On the other hand, when conduct is classified as a less serious crime and only punished lightly, he knows that society is not as concerned about the ill effects of that conduct. Thus, by classifying crimes the law can broadcast societal mores and influence the way individuals conduct themselves.

The Penal Code classifies criminal conduct in two ways. First, it clearly establishes the crimes to which it applies. Second, it classifies those crimes by severity.

\section{Islamic Law and the Penal Code}

A detailed analysis of the penal law of Islam is well beyond the scope of this chapter, however it is important to understand the relationship between the criminal law of Afghanistan and Islamic law. Thus, this section will briefly discuss certain Islamic law concepts necessary to understand this relationship. The treatment of these Islamic law topics is meant to be introductory rather than comprehensive.

Offenses in Islamic penal law are divided into three categories: 1) hudud crimes; 2) qisas crimes; and 3) ta'zir crimes. The criteria for classifying these offenses are complex, and include the gravity of the penalty as prescribed by Islamic law, the nature of the interest effected by the prohibited act, and the manner and method used in incriminating and punishing. Article 1 of the Code states: "This law regulates the 'ta'zir' crime and penalties. Those committing the crimes of 'hudud,' 'qisas,' and 'diat' shall be punished in accordance with the provisions of Islamic religious law (the Hanafi religious jurisprudence)."

Hudud crimes are the most serious crimes in Islamic penal law, as they are crimes committed against the public interest (i.e., against the state). Hudud crimes and their penalties are defined and prescribed by the Qur'an and to some extent through the Sunnah of the Prophet Muhammad (PBUH). Consequently, prosecution of hudud crimes is mandatory, and punishment 
must be imposed exactly as prescribed. Muslim scholars differ regarding the crimes that fall into the category of hudud. Generally, scholars agree on five hudud crimes (adultery, theft, banditry/highway robbery, apostasy, and defamation), but disagree on two others (rebellion and drinking alcohol). The majority of Muslim scholars, however, maintain that the latter crimes are correctly defined as hudud.

Qisas crimes are less severe than hudud crimes. They are, for the most part, crimes against the bodily integrity of a person. Homicide, intentional physical injury or maiming, and unintentional physical injury or maiming comprise this category.

Finally, ta'zir crimes are the least serious according to Islamic penal law, though they still encompass very serious crimes. There is consensus among Muslim scholars that the Muslim state has the right to criminalize and punish all inappropriate behaviors that cause damage to an individual or community as a whole. Thus, the definition of ta'zir crimes and the prescription of punishment for these crimes are left to the State. This authority must, however, be practiced within the spirit of the general rules of Islamic law (specifically the Hanafi jurisprudence in Afghanistan) and the public interest of Muslim society (maslaha). Because ta'zir crimes typically involve less serious claims - often claims of non-physical injury or claims for monetary damages - citizens often take on a more important role in bringing these crimes to the attention of the authorities.

\section{Classification of Ta'zir Crimes}

Under the Penal Code, ta'zir offenses are placed in one of three categories according to seriousness and the corresponding penalty. The most serious crimes are classified as felonies, mid-level crimes as misdemeanors, and the least serious crimes as obscenities. Felonies are crimes punishable by death, continued imprisonment (sixteen to twenty years), or long imprisonment (five to fifteen years). Misdemeanors are crimes punishable by imprisonment ranging from three months to five years, or a cash fine of more than 3,000 Afghanis. Obscenities are crimes punishable by imprisonment ranging from twenty-four hours to three months, or a cash fine of up to 3,000 Afghanis.

\section{Discussion Questions}

1. Currently, Islamic law governs the punishment of some crimes, while the Penal Code governs the punishment of others. What are the advantages of this model? What are the disadvantages?

2. Why does it make sense to classify ta'zir crimes as felonies, misdemeanors, or obscenities? How does the classification system help during investigation of a crime? How does it help at the trial? At sentencing? After an offender has completed his sentence? 


\section{PUNISHMENT AND RESTORATIVE JUSTICE}

This section turns not to the specifics of the Penal Code, but rather to a more broad discussion about why criminal law is even necessary. Why punish individuals who commit crimes? The question may seem simple at first, but answering it is not easy. Are we trying to deter the defendant in a particular case from committing future crimes? Or are we trying to deter others in the community from committing crimes? Is it because we are trying to reform or rehabilitate the defendant? Do we want to incapacitate dangerous people? Or do criminals just deserve to be punished?

You may have answered yes to all of these questions, yes to some, or yes to none. Whatever your thoughts on the issue, there is likely a legal scholar somewhere who agrees with you. There is no right answer when it comes to thinking about rationales for punishment, merely different schools of thought. This section will begin by exploring various forms of punishment, next examine the objectives and severity of punishment, and conclude by discussing the important concept of restorative justice.

\section{A. Forms of Punishment}

In the section on classification of crimes we looked briefly at how the Penal Code punishes offenders. Remember that punishments included monetary fines, imprisonment, and death.

Articles 97 through 120 of the Penal Code describe these punishments in great detail. While it is unnecessary to cover each article here, there are some points worth noting.

First, notice that under Articles 100, 101, and 102, a person sentenced to long or medium imprisonment must perform reformatory works while incarcerated, while those sentenced to short imprisonment do not. Prisoners above sixty years of age are also exempt from working.

Second, when it comes to punishment, courts generally have some discretion to tailor the punishment to the offense. That is, while the Code may prescribe medium punishment, this merely tells the court the individual must be incarcerated between one year and five years. Similarly, the Code typically gives either a minimum or maximum for the amount of a cash fine, leaving the exact amount up to the court's discretion.

Finally, notice that Articles 112 through 120 deal with consequential punishments, or other rights and privileges that may be taken away from or denied a defendant because of his conviction. These rights and privileges include, among other things, the right to State employment, the right to serve in the armed forces, the right to hold public office, the right to participate in elections, the ability to act as a witness or conclude contracts, and the ability to serve on boards of companies and banks. 


\section{B. Theories of Punishment}

The next sections will briefly examine four of the most frequently mentioned theories of punishment: 1) incapacitation; 2) rehabilitation; 3) deterrence; and 4) retribution. In considering each, we will explore the theory, major criticisms of that theory, and possible responses to those criticisms. Finally, a fifth section will be devoted to a discussion regarding the severity of punishment, and the theory that the punishment should fit the crime.

In exploring this section you may notice that punishments prescribed by one theory of punishment seem to also fit under a second or third theory of punishment. For example, the punishment of amputating a limb can be labeled incapacitation, but it seems to involve elements of deterrence and retribution as well. This is because labeling punishments is an inexact science at best, as each punishment naturally can fall into more than one theory of punishment. Keep this in mind as you read, and consider how the theories overlap in practice.

\section{Incapacitation}

Incapacitation seeks to ensure that offenders are unable to commit additional crimes. Incarceration is the most common form of incapacitation, and rests on the idea that an offender who is physically separated from society cannot harm society. That is, criminals in prison will not have access to anyone but other criminals, and therefore will have fewer potential victims.

Harsher forms of incapacitation include punishments that invade an offender's bodily integrity, such as amputation of a limb or loss of an eye. The most drastic form of incapacitation, of course, is death. Any punishment involving invasion of an offender's bodily integrity implicates international human rights law, and many have argued against such punishments as immoral.

One of the major criticisms of letting incapacitation drive punishment is that the theory could be used to prevent imprisonment. That is, according to some opponents of incapacitation, if the primary goal of punishment is to prevent future offenses by incapacitating those we think likely to commit future offenses-what stops the system from locking up those it thinks are dangerous, but have not yet committed any crime? This reasoning can be countered by pointing to the presumption of innocence as a check on preventive detention, and highlighting that we typically only punish those who have been found guilty by a competent court of law. Nevertheless, incapacitation rests on the assumption that future behavior is best predicted by past behavior - a supposition that some legal scholars find troubling.

\section{$\underline{\text { Rehabilitation }}$}

According to the rehabilitation rationale of punishment, the primary goal of punishment should be to re-socialize offenders. Typically, this view holds that correctional facilities should be used to help offenders who have displayed curable antisocial tendencies, and incapacitate those who cannot be rehabilitated. In practice, the rehabilitation model often involves establishing re-socialization programs in prisons. These programs-such as vocational training 
programs, basic education programs, and counseling programs-are designed to help offenders become productive members of society.

One of the major criticisms of the rehabilitation model is that it is overly optimistic. That is, to base a penal system on rehabilitation means believing that short-term re-socialization programs can effectively change an offender's behavior. Opponents of rehabilitation argue that rehabilitation programs in prisons are ineffective because prisons are often also places of negative re-socialization where inmates are exposed to harsh treatment and antisocial behavior. Proponents often counter that there are certain offenses-drug-related offenses, for examplethat are particularly responsive to treatment. Nonetheless, rehabilitation-like all the theories described here-remains a controversial model.

\section{Deterrence}

The deterrence theory holds the purpose of punishment is to reduce the number of offenses by raising the costs of committing an offense. For example, while an individual might vandalize public property if it costs him nothing to do so, he might not engage in vandalism if he knows he will spend two years in prison if caught. Thus, the deterrence theory essentially applies an economic cost-benefit analysis to punishment. That is, the deterrence theory asserts that if all individuals act rationally, they will not engage in criminal activity as long as the cost of committing the crime (the punishment) outweighs the benefit (the reward of the criminal activity).

Deterrence is often said to contain two separate but related ideas: general deterrence and specific deterrence. General deterrence focuses on the general prevention of crime by making an example of specific offenders. That is, the State makes the public aware of the punishment received by an individual offender to deter other individuals from committing the same crime in the future. Specific deterrence, on the other hand, focuses on deterring a specific offender. The aim of specific deterrence is to discourage an offender from future violations by making him aware of the consequences of his actions.

There are a number of standard criticisms of the deterrence model. First, some scholars take issue with the idea that all human beings act rationally (i.e., according to the cost-benefit analysis described above). These scholars argue that there are some people who will always commit crime, no matter what the punishment. A second major criticism is that basing punishment solely on its deterrent effect may lead to excessive penalties. For example, if the State truly wanted to eliminate all crime, why not prescribe the death penalty for any criminal conviction, no matter how slight? While such a question may seem absurd when taken to such an extreme, if deterrence is the only goal, what is the State's incentive to keep punishment proportionate to the offense?

\section{Retribution}

The retribution theory of punishment is perhaps the hardest to define. It is based on the idea that society is morally bound to punish people who engage in criminal activity. The idea of retribution - at least for many of its proponents - is not, however, based on vengeance. In other 
words, the retribution theory does not hold that "criminal law exists to displace, or provide an outlet for, emotions that might otherwise give rise to private vengeance." Rather, it is based on the idea that people engaged in criminal activity deserve to be punished, and it is the mandate of society to bring about that punishment.

One major criticism of the retribution theory of punishment is that it stresses the inherent flaws of those who commit crimes, and places less emphasis on the situation in which the crime was committed. Opponents of retribution often point to environmental factors outside the control of the offender-poverty, childhood abuse, and exposure to violence, for example-as being partly responsible for the offender's behavior. An individual does not deserve to be punished, the opponents would argue, for things beyond his control.

\section{Mixed (or Multiple) Theories}

It should be clear at this point that no theory of punishment is flawless. Each has its advantages and disadvantages, its costs and benefits. Consequently, few people today hold any single one of these views in its pure form. Rather, there is a tendency both on the part of legal systems and human intuition to mix and match theories. That is, many of us may believe that it makes sense to be deterrence-oriented when thinking about corporate fraud or other white collar crime, retribution-oriented as to murder, incapacitation-oriented as to vandalism, and rehabilitation-oriented as to narcotics offenses, or any other combination of theories.

\section{Severity of Punishment}

Whatever theory of punishment, when presented with a guilty party a court must decide the punishment and sentence the offender. As you'll recall, in most cases the law prescribes a punishment range, and leaves the exact punishment to the court's discretion. How does a court make this difficult decision? There are two criminal law theories that inform the sentencing decision: 1) the theory of aggravating and mitigating factors; and 2) the legal maxim that the punishment should fit the crime.

\section{Aggravating and Mitigating Factors}

The theory of aggravating and mitigating factors relies on the proposition that specific facts surrounding an offense should influence the punishment of the offender. In other words, society recognizes that all crimes of a certain type do not merit equal punishment. Amir's assault case may be very different from Rahim's assault case, and it would be unfair to punish them equally. Instead, punishment should consider the manner in which the crimes were committed and the history and background of the persons involved. Facts that increase the severity of punishment are called aggravating factors, while factors that decrease the severity of punishment are called mitigating (or extenuating) factors.

For example, Article 148 of the Penal Code provides the following general aggravating conditions:

1. When the motive of the crime is low and corrupt 
2. When the crime takes place in realization of weakness of the senses of the person against whom a felony is committed or his inability to defend himself.

3. When the crime is committed in a savage manner or the person against whom a felony is committed has been disfigured.

4. When an official of public services, making use of his official prestige and influence, commits a crime.

5. When, making use of the state of economic crisis, crime is committed.

If any of these factors are present, the court has the option of increasing the punishment described by statute.

In other articles, the Penal Code mentions other aggravating factors, such as using a weapon during a crime, committing a crime between the hours of dusk and dawn, and committing a crime in conjunction with other individuals.

Articles 141 through 147 concern the judicial treatment of mitigating factors. While the Code does not list specific mitigating factors as it does aggravating factors, it states that "judicially extenuating conditions are those instances where the crime is committed on the basis of honorable motives or where the criminal has acted because of unlawful incitement of the person against whom the crime has been committed ...."

For example, if a court finds that an employee assaulted his employer after years of being beaten, belittled, and otherwise mistreated, the court may find the existence of mitigating factors. In other words, the assault was not justified or excused, but for reasons of mercy and fairness it does not deserve to be punished as harshly as the typical assault case. Other mitigating factors might include the offender's lack of criminal history, his honorable service in the armed forces, or his dedication to public service and his community.

\section{Punishment Fitting the Crime}

There is a longstanding legal maxim that the punishment should fit the crime. For example, an offender should not be sentenced to death for simple vandalism, nor should an offender be made to pay a small cash fine when convicted of murder. The sentence should be sufficient to achieve the goal of punishment, but should not be excessive.

By prescribing appropriate sentencing ranges for specific offenses, and allowing deviation only in the presence of aggravating or mitigating factors, the Penal Code attempts to ensure that the punishment always fits the crime. Statutory sentencing ranges have the advantage of standardizing of punishment. For example, if courts follow the Penal Code as required, an offender sentenced for arson in Herat will receive a punishment similar-if not equal — to an offender sentenced for arson in Kabul. 


\section{Discussion Questions}

1. Is it important for the state to clearly identify a theory of punishment, or is it enough to simply incarcerate the guilty? In other words, do theories of punishment matter, or are they just an academic exercise?

2. What would be the advantages and disadvantages of a clearly-identified, legislativelymandated theory of punishment?

3. As discussed in this section, one of the products of mandatory sentencing ranges is the standardization of punishment. Is this fair to defendants? In other words, should judges be allowed to institute punishments more or less severe than the sentence range if they believe it is necessary? Does the aggravating factor/mitigating factor system give judges the flexibility they need?

\section{Restorative Justice}

Any treatment of crime and punishment in Afghanistan would be incomplete without a serious discussion of restorative justice. Restorative justice focuses on crime as an act against a specific individual or community, rather than against the state or society as a whole. This is fundamentally distinct from the theories of punishment described above, which all start with the assumption that a crime is an act that offends the State.

Consequently, restorative justice places a much greater influence on the victim than other criminal law theories. That is, because crime is seen as an act against an individual or a community, the objective of punishment is to restore the victim to the position he was in before the criminal act, and repair relations between the offender and the victim. In this way, restorative justice is closely tied to the ideas of reparation, forgiveness, and social harmony.

Examples of restorative justice can be found throughout Afghanistan. In fact, the local adjudicative systems that practice customary law are almost entirely based on a restorative justice model. These systems-primarily jirgas and shuras - generally punish offenders through forced reparation payments to victims and formal requests for forgiveness.

There are both advantages and disadvantages to these restorative justice systems. One of the greatest advantages is that restorative justice may create greater social harmony than retributive justice systems because both victims and offenders are included in the punishment process. In Afghanistan, this may mean ending cycles of violence commonly referred to as blood feuds. Further, because incarceration is rare, families are not separated and offenders can remain productive members of their communities.

Restorative justice systems, however, tend to rely on certain assumptions. First, there is an assumption that the victim, or some representative of the victim, is available and willing to participate in the process. Imagine, for example, a murder in which the victim was a traveling merchant with no family and no permanent home. To whom does the murderer pay reparation? 
From whom does the murderer ask forgiveness? If there is no victim, does the offender go unpunished?

Second, there is an assumption in a restorative justice system that offenders will take responsibility for their actions and show remorse for the harm caused. But what happens when an offender is convicted of a crime but maintains his innocence and refuses to ask forgiveness or pay reparation? How should that offender be punished? Should his house be burned and his family ostracized from his village? What if he is a powerful person? What if he lives in an apartment building in a city? Should his property be seized? All of his property, or just enough to compensate the victim? The answer may be to incarcerate the offender, but that raises questions regarding the theories of punishment we explored earlier. What is the objective of imprisoning the offender, and how severe should the punishment be?

Finally, one major criticism of some restorative justice practices is that these models perpetuate human rights violations or other unacceptable discriminatory practices. In Afghanistan, the foremost concern is the treatment of women and children by non-formal judicial processes. Read the following case study with a critical eye. From the perspective of dispute resolution, what advantages and disadvantages do you see in the case of Haji Sardar and Shah Tofan? From the perspective of individual rights? If you decided the case, how would your ruling have been different? Why?

\section{The Case of Haji Sardar and Shah Tofan}

At one time, a dispute arose over water allocation between two members of the Wazir tribe, Haji Sardar and Shah Tofan. The altercation escalated to the point where Haji Sardar's son shot and killed Shah Tofan's son. Haji Sardar's family was then forced to flee from the village to Pakistan.

In their absence, the village elders decided to mediate the dispute between the two families and determined that the dispute and murder could be resolved by having Haji Sardar's family give two girls and pay a fine to the family of Shah Tofan. In addition, the jirga ordered Shah Tofan to have a girl of his family marry a member of Haji Sardar's family. Shah Tofan accepted this resolution, but rejected the payment of a fine. After this compromise was reached through the jirga, there was no further incident or dispute between the families (International Legal Foundation: 12).

Interestingly, many legal systems around the world have found that criminal justice does not have to be based solely on retributive justice or restorative justice, but can use theories from both. That is, just as we discussed mixing theories of punishment earlier, restorative justice can become another tool for the criminal justice system to use when appropriate. For example, cases in which the victim and the offender both express interest in taking part in the restorative justice process might be forwarded to the appropriate dispute resolution mechanism, whether tribal elders, trained mediators, or volunteer counselors. Cases not appropriate for the restorative justice process would proceed to the formal court system. 


\section{Case Study: Sentencing Circles in Saskatchewan, Canada}

In 1992, the Canadian Province of Saskatchewan implemented a restorative justice alternative to formal court sentencing known as a sentencing circle (SC). The SC process is a response to crime that aims to address victim, offender, and community needs more fully than the formal court process. In Saskatchewan, once an offender has pleaded guilty or been convicted, the offender can choose to be sentenced by a sentencing circle rather than a court. Participation in the SC is completely voluntary, and no offenders are forced into the process.

If an offender chooses to take part in a SC, interested stakeholders come together to form a miniature community. The make-up of each SC is unique, but usually the group includes the offender, the victim, their families and friends, the judge, a prosecutor, and a defense attorney. Other members of the community — such as tribal elders or mental health/substance abuse professionals-will often take part.

The assembled community sits in a circle, and the prosecution reads the facts of the offense. The offender publicly acknowledges guilt, and takes direct responsibility for his actions. The SC then discusses the criminal conduct of the offender, and how the offender can make amends with the victim, rehabilitate, and rejoin the community. No one is forced to speak, but each participant is given many opportunities to talk. There are few formal rules, and those exist only for reasons of empathy and respect. For example, interrupting another speaker is not tolerated.

At the end of a successful SC, the group has developed a sentencing plan that is satisfactory to all stakeholders, and recommendations are made to the judge. Judges rarely refuse to follow the recommendations, which can include elements of reparation and restitution to the victim, along with a plan for the rehabilitation and societal integration of the offender (Wilson 2002: 363-80).

\section{Discussion Questions}

1. This section briefly described some advantages and disadvantages of restorative justice systems. Can you think of any others? Is it possible for a system to capture the advantages of restorative justice without experiencing the disadvantages?

2. Afghanistan has a long history of restorative justice, and many restorative justice systems are functioning effectively throughout the country. What types of cases do these systems handle well? Why? What types of cases do they not handle well? Why?

3. Criminal justice systems in other countries have successfully borrowed from both restorative justice and other theories of punishment. These systems rely on mutual recognition of legitimacy and cooperation between state and non-state justice systems. Would such a setup work in Afghanistan? Why or why not? How would you formally institute this system? How would you describe the system to someone skeptical of any centralized judicial system? 


\section{CRIMINAL PROCEDURE}

Until this point, the bulk of this chapter has been devoted to substantive criminal law. Substantive criminal law, however, is only one half of the picture. The other half is criminal procedure - the theories and rules that govern the process of deciding a case. If the difference between substance and process seems a bit confusing at this point, it may be helpful to think about it in terms of "what" versus "how."

Substantive criminal law is generally concerned with questions of "what." What did the defendant do? What was his intent? What offense did he allegedly commit? What law proscribes that crime? What are the elements of the offense?

Criminal procedure, on the other hand, is concerned with questions of "how." How do the police discover a crime? How should they treat the defendant upon arrest, interrogation, indictment? How does a prosecutor gather evidence? How is the defendant represented at trial? How are witnesses examined?

In short, the goal of criminal procedure is to ensure that the accused is treated fairly and that the criminal justice system is impartial, effective, and efficient. To meet these goals, the rules of criminal procedure must apply equally to the police, prosecutors, defense attorneys, and judges, and must be standardized throughout the justice system.

The following sections will discuss criminal procedure in Afghanistan. First, we will look at the state of criminal procedure law today, including an introduction to the 2004 Interim Criminal Procedure Code for Courts (ICPC). Next, we will briefly examine the more important aspects of criminal procedure by following a hypothetical case from investigation to appeal.

\section{A. The State of Criminal Procedure Law}

Criminal procedure varies widely between adjacent provinces, cities, and even neighborhoods. This variation is likely a product of two factors.

First, because each ethnic group, clan, and village in Afghanistan has evolved its own system of adjudication, it has been unnecessary to turn to a centralized system that cannot be adapted to the local norms. Second, even if the local authorities wanted to use the procedural rules established by the central government, it would be difficult for them to decipher which rules to apply. In the last forty years, there have been at least eight pieces of legislation containing rules of criminal procedure. The laws are sometimes contradictory, and it is unclear which should take precedent.

Progress is being made, however, to improve the situation. The adoption of the ICPC in 2004, addressed the question of which criminal procedure law applies. The ICPC is an interim criminal procedure code that trumps contrary pre-existing law. This means that on most procedural questions, the ICPC is the governing law. There are, however, a number of procedural issues not addressed by the ICPC, and for instruction on these issues it is necessary to turn to 
earlier codes. Further, as of the printing of this text, the ICPC has only been partially implemented, and efforts to fully implement a comprehensive criminal procedure code are ongoing.

The ICPC contains fifteen chapters and ninety-eight articles. These articles cover everything from the provisional arrest of suspects to Supreme Court appeals. Rather than consider each article in isolation, the next sections will follow a hypothetical criminal case from the commission of the offense to the final appeal. This is not meant to be a complete treatment of the ICPC - there are many important rules that will not be discussed here-but rather an introduction to the most important procedural concepts. Also, it should be noted that this is the ideal treatment of a case based on the ICPC rules. While efforts have been made toward the implementation of these rules, the following story may still be more of an aspiration than reality in many parts of Afghanistan.

\section{Arrest and Detention}

It is a Monday evening in late spring, and two policemen are patrolling in Kabul. As they pass a shop, they hear a series of loud noises coming from inside. They inspect the front of the store and notice that the windows have been broken and the door is ajar. Entering through the open door, they find a young man breaking shelves, scattering merchandise, and generally vandalizing the store. Under Article 13 of the ICPC, the police have caught the young man "in flagrante delicto," or "in the moment the crime is being committed."

Using the power given them under ICPC Articles 30 and 32, the police arrest the vandal and search him. They also search the immediate area around the young man, collecting any evidence they think may be useful in the prosecution of the crime. The police then take the suspect to the local police station. At the police station, the police clearly inform the young man of the reasons for his arrest (Article 31) and explain to him his right to remain silent (Article 5); his right to be present during searches, line-ups, expert examination, and trial (Article 5); and his right to be represented by counsel at all times (Article 18), including the right to have a lawyer appointed by the government if he cannot afford one (Article 19). The police then interrogate the young man about the circumstances of the vandalism (Article 31).

By Tuesday afternoon (i.e., within twenty-four hours of arrest), the police have sent a report of the crime and the interrogation to the prosecutor, called the Primary Saranwal (Article 31) and put the suspect at his disposal. Upon receiving the file, the Primary Saranwal looks over the record and approves of the actions taken by the police (Article 33), deciding to hold the suspect for further interrogation.

On Wednesday morning, the Primary Saranwal visits the suspect for the first time to interrogate him. At the beginning of the meeting, the suspect tells the Primary Saranwal that he will not answer any more questions until he has spoken to an attorney, and that he is financially unable to hire one. The Primary Saranwal tells the suspect he will have defense counsel appointed, and does not interrogate him. 
The Primary Saranwal then consults the official register of lawyers permitted to work as defense attorneys - kept by the Ministry of Justice - and appoints an attorney for the suspect (Articles 18, 19). The Primary Saranwal contacts the attorney, who meets with the suspect in the police station, and is present when the Primary Saranwal carries out the interrogation (Article 38). If there are no qualified defense lawyers available, the suspect may have the assistance of an educated person having some knowledge of legal issues (Article 96).

By Thursday afternoon (i.e., within forty-eight hours of receiving the suspect), the Primary Saranwal has interrogated the suspect and found there is enough evidence to continue the detention (Article 34). At no time has the suspect been intimidated by the police or Primary Saranwal, or undergone any form of physical or psychological pressure (Article 5).

\section{Investigation}

Over the next two weeks, the Primary Saranwal investigates the crime and collects evidence (Articles 36 and 37). He conducts the investigation both on his own and in conjunction with the police, who he instructs (Article 23). The Primary Saranwal and the police notify the suspect and his attorney prior to any search, confrontation, line-up, or expert examination, so that they can be present (Article 38).

Within fifteen days of the original arrest, the Primary Saranwal must decide to indict the suspect, release him, or request an extension from the Court (Article 36). The Court may authorize one extension of not more than fifteen additional days (Article 36). If, at the conclusion of the investigation, the Primary Saranwal decides there is not enough evidence to proceed, he must dismiss the case and release the defendant (Article 39).

In this case, the Primary Saranwal decides there is enough evidence to proceed, and submits to the Court the act of indictment, requesting a trial to assess the suspect's criminal liability (Article 39). The indictment contains a complete identification of the suspect, and a complete description of the crime (Article 39). At this point, the suspect officially becomes the accused (Article 5), and the Court can hold a hearing to set bail (see footnote 60 above). The Court sets bail, but neither the accused nor his family is able to post bail, so he remains in custody.

Along with the indictment, the Primary Saranwal sends the complete file containing all information relating to the accused to the Court (Article 39). The accused and his defense counsel are entitled to examine the documents in this file along with all items the Primary Saranwal is holding as evidence (Article 43). The Court has the power to dispose of these items as it deems necessary (Article 39).

Immediately after receiving the indictment, the Court orders notification of the deed indicating the date and time set for the trial (Article 42). This deed contains the name of the accused and the indication of the alleged crime with its factual circumstances and references to the related law provisions (Article 42). It is served on the accused and his defense counsel, the victim shopkeeper, and the Primary Saranwal, at least five days before the trial is set to begin (Article 42). 
Because the accused in this case is not released on bail, the Court has two months from the day the indictment is filed to hear the case and announce a decision (Article 6). During this time, the accused is held at a detention center generally maintained by the Ministry of Justice. If the accused had been released on bail, the delay between indictment and judgment may have been longer than two months.

\section{$\underline{\text { Trial }}$}

Before the trial, the Primary Saranwal submits to the Court a list of witnesses and experts he wants to be heard, and indicates the relevance of the testimony they will give (Article 51). The accused will submit a similar list if he wishes to call any additional witnesses or experts (Article 51). After examining these lists, the Court can exclude witnesses or experts it deems irrelevant, and may add witnesses or experts not included on the original lists (Article 51). Witnesses and experts will be notified that their presence is required, and will be duty-bound to attend the hearings indicated in the notice (Article 49).

On the day of the trial, all interested parties will gather at the courthouse. At the very least, the trial will be attended by the Primary Saranwal, the accused and his counsel, the victim, witnesses and experts, and the Judge. In addition, all hearings are open to the public unless closed for reasons of morality, family confidentiality, or public order (Article 52).

The hearing begins with the Head of the Court explaining the order of the trial to everyone present (Article 52). Next, the following proceedings occur in order (Article 53):

- The Court reads out the act of indictment;

- Because the accused is under detention, the Court immediately assesses the legality of the arrest;

- The Primary Saranwal presents the case and the findings of the investigations;

- The police officers who conducted the investigations present a report of their activities;

- The first witness heard is the victim shopkeeper;

- All other witnesses and experts are heard;

- The accused questions the witnesses and experts;

- The accused testifies if he wishes;

- The Primary Saranwal questions the accused.

In addition, the Court can question the accused and witnesses and experts at any time (Article 53). The accused can refuse to testify and refuse to answer the Court's questions consistent with his right to remain silent (Article 53).

At the conclusion of these proceedings, the Primary Saranwal indicates the type and level of punishment he thinks adequate (Article 58). The accused or his counsel presents arguments to rebut the accusations made by the Primary Saranwal (Article 58). The Court then declares the hearing "closed," and retires to chambers to write down the decision of the case (Article 59). In reaching this decision, the Court may not rely on any testimony in the file unless that testimony 
was repeated during trial, or the accused or his counsel was present when the testimony was made (Article 55).

After reaching a decision, the Court enters the courtroom and reads the decision (Article 59). The decision contains: 1) the identification of the accused; 2) the description of the facts and circumstances contained in the indictment; 3) the verdict; and 4) a short description of the reasons for the verdict, including references to facts and law (Article 61). In this case, imagine the accused was found guilty.

\section{Appeal}

After the decision has been announced, the accused has twenty days to file an appeal (if the defendant had been found not guilty, the Primary Saranwal would likewise have twenty days to appeal) (Article 63). The appeal is filed with the secretary of the Primary Court in which the decision was made, or with the secretary of the Provincial Court that has jurisdiction (Article 63). The appeal indicates the contested decision and states the reasons the decision is wrong (Article 66).

When a decision is appealed, all files are transferred from the Primary Court to the President of the Provincial Court, who sets a date and time for hearing (Article 67). The Provincial Court then notifies the Provincial Saranwal, the accused, and defense counsel of the scheduled hearing (Article 67). This notification must be served at least five days before the hearing (Article 67).

At the appellate hearing, the Court only reviews the parts of the decision that the accused thinks are incorrect (Article 68). After both sides present arguments, the Court decides either to make a decision on the evidence in the file, or to hear from witnesses and collect new evidence (Article 69). If the Court decides it needs more information, it may consider evidence not offered by the Saranwal or the accused. After the Court is satisfied that it has enough evidence to decide the case, it confirms or modifies the previous decision, in whole or in part (Article 70). The Court may not, however, increase the punishment on the accused (Article 68).

After the Court of Appeal has ruled, the accused, the victim, or the Saranwal can file an appeal with the Supreme Court within thirty days of the appellate decision (Article 71). The Supreme Court only reviews decisions of the appellate court for mistakes in application or interpretation of law, or if the lower courts improperly admitted evidence (Article 71). After holding a hearing, the Supreme Court can amend the earlier decision, quash the decision in full and dismiss the case, or quash the decision in full or in part and refer the case to a Provincial Court for reconsideration (Articles 78, 79, and 80). There is no appeal from the decision of the Supreme Court.

After a final decision has been rendered, the Saranwal is responsible for executing the final decision (Article 84). This means informing the local police commander of the sentence (if the accused is free) or informing the Ministry of Justice of the sentence (if the accused is detained) (Article 85). In cases where the sentence includes incarceration, any time served by the accused before the final decision is deducted from the sentence (Article 89). In cases where the 
sentence includes fines, the Saranwal informs the Ministry of Justice of the order, which collects the fines for the Ministry of Finance (Article 87).

\section{Discussion Questions}

1. The Constitution and the ICPC guarantee the accused the right to have the assistance of counsel during criminal proceedings. Why? What is the advantage of being represented by counsel? Why should the government have to pay for counsel for indigent defendants?

2. The ICPC also guarantees the accused the right to proceed without defense counsel. If a representation is so important, why let untrained defendant's represent themselves?

3. The ICPC gives the victim of a crime the right to appeal a ruling of the appellate court, but not a ruling of the Primary Court. Why? Is the power of appeal too much power for a victim? Not enough power? What are the advantages and disadvantages of including the victim in the formal criminal justice system?

\section{CRIMINAL LAW STATUTES}

Earlier, when we considered the basics of criminal law, you learned about the principle of legality. Recall that the principle of legality requires that offenses be clearly expressed and easily ascertainable. In Afghanistan, this requirement is satisfied through the enactment and publication of criminal laws. This section will briefly consider five of the most important statutes relating to substantive criminal law (i.e., statutes that define offenses and prescribe punishments for those offenses). The purpose of this section is not to teach specific offenses, but rather to give students an understanding of the sources of criminal law in Afghanistan and introduce statutes that will assist interested students in further study.

\section{Penal Code (1976)}

You are already familiar with parts of the Penal Code from earlier sections. Recall that the Penal Code, enacted in 1976, was the first comprehensive codification of criminal offenses in Afghanistan and covers all ta'zir crimes.

The Code was published in Official Gazette No. 347. It contains 522 articles and is broken up into two books. The first book-Articles 1 through 172-covers general provisions and definitions, including explanations of the elements of a crime, the principles of liability, punishments, justification and excuse, aggravating and mitigating factors, and dismissal of crimes and punishments. The second book-Articles 173 through 522-lists specific offenses and punishments for those offenses. These offenses range from embezzlement to destruction of public buildings to defamation and everything in between.

The Penal Code is still in effect, and remains the most comprehensive criminal law in Afghanistan. Many offenses are still regulated according to the Penal Code, and the Code should be the primary resource for practicing criminal lawyers. It is important to note, however, that 
subsequent laws have superseded some provisions of the Penal Code. Thus, while the Penal Code should be a primary resource, it should never be the only resource.

\section{Law on the Campaign against Bribery and Administrative Corruption (2004)}

The Law on the Campaign against Bribery and Administrative Corruption (Anti-Bribery Law) was adopted in 2004 and published in Official Gazette No. 838. It was passed in accordance with Article 50 ("The state shall adopt necessary measures to create a healthy administration ....") and Article 75(3) ("The government shall have the following duties:. . . to maintain public law and order and eliminate every kind of administrative corruption ....") of the Constitution. It contains fifteen articles broken into three chapters: 1) General Provisions; 2) Duties and Powers [of the Office for the Campaign against Bribery and Administrative Corruption, which it created]; and 3) Organization [of the Office].

The main penal provision of the Anti-Bribery Law criminalizes official corruption, which it defines as "an. . . act committed by government employees and other public servants to attain personal or group aims ...." (Article 3).

It is important to note that the Anti-Bribery law was passed as an addition to-not a replacement of - the bribery provisions of the Penal Code.

\section{Law on the Campaign against Financing Terrorism (2004)}

The Law on the Campaign against Financing Terrorism (Terrorism Finance Law) was adopted in 2004, pursuant to Article 7 of the Constitution, which asserts that "The state shall prevent all kinds of terrorist activities ...." The Terrorism Finance Law consists of six chapters containing thirty-four articles, and was published in Official Gazette No. 839.

The purpose of the Terrorism Finance Law is to combat terrorism by cutting off terrorists from their financial supporters. By criminalizing the financing of terrorism, the government can prosecute not only those directly involved in terrorism, but those who facilitate terrorism. The crux of the Terrorism Finance Law is Article 3.

\section{Terrorism Finance Law}

\section{Article 3}

Any person commits the offense of the financing of terrorism who by any means, directly or indirectly, unlawfully and willfully, provides or collects funds and property, or tries to provide or collect funds and property, or provides or tries to provide financial or other services with the intention that they should be used or in the knowledge that they are to be used, in full or in part, in order to carry out. . . any act intended to cause death or serious bodily injury to a civilian, or to any other person not taking an active part in the hostilities in a situation of armed conflict, when the purpose of such act, by its nature or context, is to intimidate a population, or to compel a government or an international organization to do or abstain from doing any act. 
Article 3 also criminalizes participating in any of the above activities as an accomplice, or organizing, directing, or motivating others to commit such activities. The penalties for individuals financing terrorism include a prison sentence between five and fifteen years, and a fine between 250,000 and 1.5 million Afghanis (Article 4). The penalties for corporate entities financing terrorism include significantly higher fines (Article 4).

\section{Law on the Campaign against Money Laundering and Its Proceeds (2004)}

Like the Bribery Law and the Terrorism Finance Law, the Law on the Campaign against Money Laundering and Its Proceeds (Money Laundering Law) was adopted in late 2004. It was published in Official Gazette No. 840. The purpose of the Money Laundering Law is "to prevent and prohibit the use of financial institutions or any economic activities for money laundering and for the financing of terrorism." (Article 1)

Money laundering is defined in Article 3 of the Money Laundering Law. While the actual offense is too lengthy to reproduce here, generally an individual is guilty of money laundering if he conceals, disguises, converts, transfers, removes from or brings into Afghanistan any funds or property derived from illegal acts or omissions.

The Money Laundering Law also contains provisions concerning transparency in financial transactions, the detection of money laundering, and the freezing of financial transactions.

The penalty for money laundering is imprisonment for between two and five years, and/or a fine of between 50,000 and 250,000 Afghanis.

\section{Counter-Narcotics Law (2006)}

The Counter-Narcotics Law was enacted in 2006 and published in Official Gazette No. 875, replacing an earlier Counter-Narcotics law from 2003. Like the Terrorism Finance Law, it derives its legitimacy from Article 7 of the Constitution ("the state shall prevent. . cultivation and smuggling of narcotics, and production and use of intoxicants").

The purpose of the Counter-Narcotics law is "to prevent the cultivation of opium poppy, cannabis plants, and coca bush and the trafficking of narcotic drugs, and to control psychotropic substances, chemical precursors, and equipment used in manufacturing, producing, or processing of narcotic drugs and psychotropic substances" (Article 1).

The Counter-Narcotics Law contains fifty-eight articles broken into eight chapters. Chapter 1 is devoted to general provisions, and contains an exhaustive list of definitions relating to the production, transportation, and use of narcotics. Chapter 2 establishes a classification system for narcotics, in which plants and substances are placed into one of four categories: 1) prohibited plants and substances with no medical use; 2) strictly controlled plants and substances with a medical use; 3) controlled plants and substances with a medical use; and 4) chemical precursors. 
Chapter 3 regulates the licensing, cultivation, production, manufacture, trading, distribution, and use of the plants and substances described in chapter 2. Chapter 4 contains the relevant penal sections, including descriptions of offenses and penalties relating to association with narcotics. Chapter 5 deals with adjudication of narcotics offenses, and creates special narcotics tribunals to try the most serious narcotics cases. Chapter 6 contains provisions on the search, seizure, and investigation techniques used in dealing with narcotics-related offenses. Note that these provisions supersede the ICPC rules in narcotics cases, and are excellent reading for students interested in further criminal procedure reading.

Finally, Chapters 7 and 8 regulate the Ministry of Narcotics and other security authorities responsible for enforcing narcotics laws.

\section{Discussion Questions}

1. Do you see a pattern in the types of offenses addressed by post-Taliban criminal statutes? Why were these laws enacted? Why wasn't the Penal Code sufficient in addressing these types of crimes?

2. Do the post-Taliban criminal laws tell us anything about the elasticity of Afghan criminal law? In other words, do you think criminal law in Afghanistan is successful in meeting new challenges?

3. What new offenses will the criminal justice have to face in the next year? Five years? Twenty years?

\section{CHALLENGES FACING THE CRIMINAL JUSTICE SYSTEM}

The next sections will consider the future of criminal law in Afghanistan. Specifically, what are the greatest challenges facing the criminal justice system and how can it address those challenges? While there are many answers to this question, we will only explore two major challenges here: 1) integration of state and local systems; and 2) resource constraints.

\section{A. Integration of State and Local Judicial Systems}

Early in the chapter we considered the difference between the state-sponsored "formal" legal system and "informal" local adjudicatory systems, and reviewed some advantages and disadvantages of each. Later, the sections on punishment and restorative justice explained the different ways the two systems deal with criminals, and examined whether theories from each could be combined to create a hybrid system such as the one used in Saskatchewan, Canada.

You may have considered these questions simple thought exercises, but the underlying issues are very real. Many people in Afghanistan prefer the local systems to the state-sponsored systems for a variety of reasons. Some consider the state-sponsored criminal justice system slow, bureaucratic, and corrupt, and some see it as an intrusion by a far-away government on their 
culture and way of life. Others note the local systems' focus on social harmony and reparation, and argue that these systems affect greater societal good than the prison-focused state system. In the eyes of many of these people, the local systems are working well.

For others, however, the local systems are not working. Despite protections offered by international law, the 2004 Constitution, Islamic law, and various provisions of Afghan criminal statutes, many local systems still deprive women of equal protection under the law. For example, recall the case of Haji Sardar and Shah Tofan from Section 5. The case was resolved when one family was compelled to give two girls to another family. Such systematic abuse of women is perhaps the strongest reason to favor the court system envisioned by the 2004 Constitution.

Another argument in favor of the state system is that as Afghanistan continues to develop, travel will become easier and people will become more mobile. This will inevitably lead to differences between local systems becoming more apparent as the population shifts. In this scenario, regional and/or national standardization of crime and punishment will be increasingly important as the lines between local systems become blurred.

In short, the criminal justice system faces a dilemma. The state must continue to prosecute crimes and enforce the law throughout the country (including gender equality laws that may offend local jirgas and shuras), but local mechanisms must play a critical role in reconciling victims and perpetrators, and their families or tribes.

Perhaps the greatest challenge for the criminal justice system of Afghanistan will be addressing this dilemma in a way that satisfies the concerns of both the state and local systems. One possible solution would be to adopt restorative justice principles into the state system. Another possible solution is to "formalize" the local systems by explicitly recognizing them through statute, reforming their treatment of women, and giving them competency to deal with certain minor crimes.

Many other methods of integrating the two systems have been proposed, but for all the proposals, little progress has been made towards integration. The continuing existence of two separate criminal justice systems is an ongoing challenge, and one that is unlikely to be resolved without a serious commitment from all stakeholders.

\section{B. Resource Constraints}

A second major issue facing the criminal justice system in the immediate future is the lack of adequate resources. While many parts of the government are operating under similar resource constraints, the problem is particularly notable when it directly affects issues of liberty and justice. For example, as mentioned earlier in this chapter, only a small fraction of the estimated 8,000 to 10,000 suspects arrested every year receive the assistance of counsel guaranteed them by the Constitution. The lack of qualified criminal defense attorneys is part of a general shortage of lawyers, but evidence suggests that the problem is even greater in criminal defense than elsewhere. For example, while there are over 2,000 prosecutors in Afghanistan, as 
of March 2008 there were under 400 lawyers licensed to practice in court registered with the Attorney Registrar's Office.

The lack of resources extends beyond the shortage of attorneys. The judiciary is in dire need of access to legal research materials, updated laws, and important judicial opinions. Without access to up-to-date written materials, judges are forced to rely on old laws (if available) or simply on their own good judgment. Needless to say, it will be nearly impossible to affect legal reform if those entrusted with implementing the new system are not aware of the laws.

Currently, international aid organizations play a major role in judicial reform. Many judges have received training from international agencies, and other donors have helped build courthouses throughout the country. And while the continued support of the international community is essential, the legal and academic communities in Afghanistan must play a role in reform. Raising public awareness and understanding of the Constitution and laws may help reforms take hold.

\section{Discussion Questions}

1. Can you think of specific examples of local and state-sponsored justice systems working together? What was the result? Do you think cooperation is possible in other areas? If you were in charge of integrating the systems, how would you get local leaders to "buy-in" to a hybrid system?

2. What can you do to raise awareness of what you have learned in this chapter? How can raising awareness of the laws help the criminal justice system?

\section{CONCLUSION}

In this chapter you have learned about criminal law and the criminal justice system. You have learned the about the history of criminal law in Afghanistan and the continuing importance of local adjudicatory systems. You have examined the institutions that make up the criminal justice system and the ways those institutions interact. You have studied the basics of criminal law, including the presumption of innocence, the principle of legality, the principles of criminal liability, and defenses. You have investigated the relationship between Islamic law and the Penal Code, and considered various theories of punishment, including restorative justice. You have been introduced to the basics of criminal procedure, and followed a case from the commission of an offense to the ruling of the Supreme Court. You have investigated some of Afghanistan's more important criminal law statutes, and seen how criminal law changes over time and adapts to new threats. Finally, you have thought about the obstacles the justice system will confront as it continues to rebuild, and considered how to address those issues. In short, you have become familiar with the past, present, and future of criminal law in Afghanistan.

For some, this may be the beginning of criminal law studies; for others, it may be the end. For all, however, it is an invitation to participate. Whether you participate as a judge, a prosecutor, a defense attorney, a police officer, or a concerned citizen, there is a role for you. The 
criminal justice system of Afghanistan faces serious challenges in the coming years, and it will need the help of all people in Afghanistan to succeed. 


\section{Sources Consulted}

Afghanistan Justice Sector Support Program. 2007. Briefing Report.

Afghanistan Legal Documents Exchange Center. http://www.afghanistantranslation.com/.

Afghanistan Ministry of Justice Official Website. http://www.moj.gov.af/.

Ahmed, Faiz. 2005. "Judicial Reform in Afghanistan." Hastings International \& Comparative Law Review 29 (93).

Barfield, Thomas, Neamat Nojumi, and J. Alexander Thier. 2006. The Clash of Two Goods:

State and Non-State Dispute Resolution in Afghanistan. United States Institute of Peace. http://www.usip.org/files/file/clash_two_goods.pdf. In Dari at http://www.usip.org/files/file/clash_two_goods_dari.pdf.

Dubber, Marcus and Mark Kelman. 2005. American Criminal Law. Foundation Press.

International Legal Foundation. The Customary Laws of Afghanistan. http://www.theilf.org/Customarypercent20Laws.pdf.

Sanad, Nagaty. 1991. The Theory of Crime and Criminal Responsibility in Islamic Law: Shari'a. University of Illinois-Chicago Press.

United States Agency for International Development - Afghanistan Rule of Law Project. 2005. Field Study of Informal and Customary Justice in Afghanistan.

Wilson, Robin, et al. 2002. "Restorative Justice Innovations in Canada." Behavioral Sciences and the Law 20: 363-380.

Zimring, Franklin E. and Gordon J. Hawkins. 1995. Incapacitation: Penal Confinement and the Restraint of Crime. 


\title{
CHAPTER 7: LEGAL RIGHTS IN AFGHANISTAN
}

\author{
A river is made drop by drop \\ - Afghan Proverb \\ شود نمى آر ام دنىا گَفتن باصلح \\ The world will not find rest by just saying "Peace." \\ - Afghan Proverb
}

\section{INTRODUCTION}

What are "rights" and why do they matter in Afghanistan? The answers to these questions are much more complex than they appear. Rights shape our views of the most basic and fundamental aspects of society. What actions should be allowed? What actions should be forbidden? What institutions are just and legitimate? Rights help us answer these questions. Rights confer freedom to individuals and authority to institutions. A deeper understanding of rights is fundamental to understanding society, culture and government in Afghanistan.

This chapter will explore legal rights in Afghanistan. It will begin by briefly defining rights and then describe the long tradition of individual rights in Afghanistan. Past constitutions embrace fundamental rights and demonstrate Afghanistan's history of recognizing the importance of rights.

Next, the chapter will develop a framework to help you dissect and analyze "rights." This section will discuss individual duties (the opposite of rights), remedies for rights violations, limitations on rights, and different categories of legal rights.

The chapter will then apply this analytical framework to the 2004 Constitution and current laws and will explore the wide array of rights guaranteed by the 2004 Constitution. It will describe the duties of citizens of Afghanistan and discuss international human rights standards. The chapter will conclude by focusing on the enforcement of rights and remedies in Afghanistan.

It would be naïve not to acknowledge that many rights are not adequately enforced or protected in Afghanistan. A handful of individual rights guaranteed by the Constitution are enforced in Kabul, but in few other places throughout the country. Considering this reality, we will focus our discussion on those rights that matter most in Afghanistan and that are realistically attainable in the near future, such as bodily integrity, nondiscrimination, and a right to an education.

Rights play a central role in promoting economic development, the rule of law, and democratic governance. It is a mistake to discount the importance of legal rights for Afghanistan's future even though many rights exist on paper only at present. 
After reading this chapter, you should have a better understanding of rights, in general, and your rights as a citizen of Afghanistan. You should also be aware of the classic rightsresponsibilities nexus, especially the duties of citizens of Afghanistan.

This chapter should also give you the tools to form your own opinions about why rights matter. There are two key questions to keep mind when reading this chapter: what rights should exist in Afghanistan and how should they be secured? These questions are deceptively complex and important. Answering them will force you to think like a lawyer to evaluate two of most fundamental issues facing Afghanistan today.

\section{THE TRADITION OF RIGHTS IN AFGHANISTAN}

\section{A. A Definition of Rights}

A right is an entitlement held by an individual (or institution) that either permits it to act in a certain way or prevents it from doing so. Rights include both acts you yourself may undertake and the actions of others that may affect you. Rights may also be described as legitimate expectations that arise from the adoption of authoritative rules. In this sense, rights identify an interest to be protected and supported by the acts or inaction of others.

Rights emanate from many sources, such as universal concepts, religion, morality, or the law. These different theories of rights are all important, but this chapter will focus on those most directly linked to legal rights in Afghanistan. One of the most widely discussed subset of rights is human rights - rights that are said to belong to every human being in every society everywhere in the world. Human rights are predicated upon the belief that all human beings innately possess the most basic and fundamental rights, which may not be curtailed by any government. Legal rights (the focus of this chapter) are rights that exist under the rules of a legal system. The Constitution of 2004, laws, treaty obligations, and court decisions are sources of legal rights in Afghanistan.

Historical tradition, local custom and Islam have also shaped rights in Afghanistan. Islamic teachings have long embraced the concept of fundamental rights. Islam may be considered one of the earliest sources of human rights. Rights are also infused throughout Afghanistan's long and distinguished philosophical and poetic traditions.

Many rights that this chapter examines are individual rights that represent justified claims upon society for different types of goods or benefits that are essential for individual liberty, dignity, and wellbeing; they also reflect common beliefs about justice and fairness. The existence of rights also implies the obligation of society to satisfy them. Every country, including Afghanistan, must develop the institutions and provide the resources to meet these claims. This is usually easier said than done.

Consider, for example, how crucial a secure environment is for your daily life. Physical security permits you to walk down the street to go to school, the market, or mosque. Without such security, you are unable to move freely and enjoy your liberty as a citizen of Afghanistan. 
The provision of this very basic need remains a challenge in many parts of Afghanistan. In other words, your right to life is directly linked to the ability to enjoy a secure environment.

\section{Case Study 1: Freedom of Expression}

On April 15, 2008 the Ministry of Culture and Youth Affairs ordered all private television stations in Afghanistan to stop broadcasting five Indian soap operas, including Kumkum and Life's Test. The Minister of Culture made his decree after meeting with the Council of Clerics, which expressed concern that the programs conflicted with Islam and Afghanistan's culture. Many members of the National Assembly expressed similar views and urged the Minister ban "offensive" programming. Private television stations, including Ariana and Tolo, complained that the decree was an illegal limitation of their freedom of expression guaranteed under the 2004 Constitution and Media Law. They emphasized the importance of the freedom of speech and argued that the Minister of Culture does not have the power to ban television programs. The soap operas were so popular that they generated enough revenue to fund news broadcasts and public service announcements.

This episode highlights the importance of fundamental rights, such as the freedom of expression, in Afghanistan. It raises important questions about legal rights: This is but one example of how your individual rights are impacted by the government and actions of others. This chapter will give you the tools needed to analyze this and other rights issues from a legal perspective. In section III, we will analyze the freedom of expression under Article 34 of the Constitution as well as the Media Law. After reading the chapter, your opinion of the abovedescribed events may change.

\section{Discussion Questions}

1. Is the freedom of expression important for a stable, secure society? Is it important to you and your friends and family? Why or why not?

2. Should freedom of speech be limited? If so, under what circumstances? How and by whom should it be limited?

\section{B. Fundamental Rights under Islam}

Any discussion of legal rights in Afghanistan must begin by examining rights within the framework of Afghanistan's rich religious and cultural heritage. Islam is a defining feature of Afghanistan, and, as such, its view of rights is directly linked to legal rights in present-day Afghanistan. Islam has established universal fundamental rights for humanity that must be observed and respected. Islam recognizes that every person is entitled to certain basic rights by virtue of his status as a human being. Even non-Muslims are guaranteed certain fundamental rights in an Islamic state. Such rights can be described as human rights within Islam because God grants them to all persons. No individual or institution has the authority to violate or withdraw 
rights conferred to human beings by God. Fundamental rights are a central part of the Islamic faith and, as such, it is the duty of all Muslims (and the state) to recognize and respect the rights of others. Nonetheless, there is ongoing debate within certain circles about the precise bounds of Islamic law. Such discussions are important, but beyond the scope of this chapter.

Islam protects many basic human rights. The Qur' an enumerates the first and most basic human right, the right to life. It links the life of each individual to that of the entire community. Each life, therefore, must be treated with utmost respect and care. Islam's protection of the right to life highlights the intersection between human rights and the law.

Islam also protects the right to liberty or individual freedom. The Qur'an's strong condemnation of slavery and those who deprive free men of their liberty indicates strong support for a right to freedom. Islam further protects basic due process rights, such as the right to be considered innocent until proven guilty in open court. For example, the Prophet Muhammad once delivered a lecture in a mosque when a man rose and asked the Prophet for what crime had the man's neighbors been arrested. The Prophet appeared not to hear the question and continued his lecture. The man rose again and repeated the question. The Prophet again appeared not to hear it and continued to speak. The man rose for a third time and asked again, at which point the Prophet ordered the man's neighbors to be released. The Prophet did not initially answer the question because the police officer that had arrested the man's neighbors was present at the mosque. If there had been a valid reason for the arrest, the officer would have given it. The Prophet ordered their release because the lack of justification for the neighbors' arrest violated their rights under Islam.

Islam further recognizes the absolute equality of all persons regardless of race, color, nationality, or tribe. All human beings are granted the right to equality as their birthright because all are brothers and sisters who are descendants of the same mother and father. No nation, race, or tribe is superior to another. In the words of the Prophet Muhammad, "No Arab has any superiority over a non-Arab, nor does a non-Arab have any superiority over a black man, or the black man any superiority over the white man. You are all the children of Adam, and Adam was created from Clay" (Bayhaqi and Bazzaz). Likewise, Islam protects every person's the right to equality under the law. Senior government officials and common citizens are all equal in the eyes of the law.

Men and women are also equal in Islam. First and foremost, through the Qur'an, women and men were created from one soul and equally important, both have equal rights to salvation by God. In other words, and in contrast to the past, the Qur'an affirmed that women were souls entitled to the same Paradise that men were allowed. No woman could be denied her right to faith and to live properly alongside men in society. In fact, at the time, Islam was the most progressive religion in the Near East. The Qur'an specifically banned the killing of baby girls, granted women the right to inherit land and property, to divorce their husbands and to maintain their dowries; and dramatically slowed polygamy in the Arabian Peninsula. In Islam, women and men are subject to the same religious obligations such as prayer, fasting, and a pilgrimage to Mecca. In addition, under Islamic law, a woman's right to own property is just as absolute as a man's. Male kin cannot handle a woman's financial interests without her permission. Moreover, under Islamic law, woman must specifically consent to marriage and cannot be forced to accept a 
husband she does not want. Under Islamic law, marriage was no longer viewed as a "status" but rather as a "contract," in which the woman's consent was imperative. In cases of divorce, women have exclusive guardianship rights over children until their children reach puberty, an important departure from past practice.

Islam also embraces freedom of religion and worship. The Qur' an prohibits coercion in matters of faith. Religion is not to be compelled upon anyone. A traditional Afghan proverb, "Let Christians practice their own religion, and Jews practice theirs," reflects Islam's guarantee of an individual right to freedom of religion. Islam thus protects the rights of non-Muslims living in Muslim countries to follow their own faiths.

On August 5, 1990, Afghanistan and the fifty-six other member states of the Organization of the Islamic Conference (OIC) adopted the Cairo Declaration on Human Rights in Islam. It summarizes Afghanistan and other Muslim countries' views on human rights under Islam. The twenty-five articles of the Cairo Declaration reflect Islam's guarantee of many fundamental rights, as discussed above. The introduction of the Declaration affirms that "fundamental rights and universal freedoms in Islam are an integral part of the Islamic religion and that no one as a matter of principle has the right to suspend them in whole or in part or violate or ignore them in as much as they are binding divine commandments."

Article 1 of the Cairo Declaration reaffirms the equality of all persons "without any discrimination on the grounds of race, colour, language, sex, religious belief, political affiliation, social status, or other considerations." This powerful statement reflects Islam's commitment to equality of all persons, including equality between followers of different religions, members of different tribes, and between men and women. Article 6 further clarifies that "[w]oman is equal is to man in human dignity, and has rights to enjoy as well as duties to perform; she has her own civil entity and financial independence, and the right to retain her name and lineage." Article 19 affirms "all individuals are equal before the law, without distinction between the ruler and the ruled."

Article 2 of the Declaration reiterates that "[1]ife is a God-given gift and the right to life guaranteed to every human being. It is also "the duty of individuals, societies, and the state to protect this right from any violation..." Article 2 further states "safety from bodily harm is a guaranteed right" that the state must safeguard. Articles 19 and 20 reaffirm related rights, such as the rights to liberty and freedom. Article 19 affirms that a "defendant is innocent until his guilt is proven in a fair trial in which he shall be given all the guarantees of defence." Moreover, Article 20 recognizes every person's right not to be tortured or treated cruelly. The Cairo Declaration also reflects Islam's protection of the right to an education (Article 9), right to work (Article 13), right to own property (Article 15), right to privacy (Article 18), and right to freedom of expression (Article 22).

\section{History of Constitutional Rights in Afghanistan}

Individual rights have also been part of Afghanistan's more recent political and legal discourse. Afghanistan's first Constitution guaranteed basic rights to all inhabitants. That Constitution contained a chapter on "General Rights of the Subjects of Afghanistan," 
enumerating more than fifteen specific fundamental rights. It guaranteed, among others, the right to personal liberty (Art. 9) and the equality of all Afghan citizens (Art. 16). It also protected the right to education (Art. 14), right to own property (Art. 19), and right to privacy in one's home (Art. 20), among others. The 1923 Constitution also prohibits torture (Art. 24).

The 1931 Constitution, passed during the reign of Nadir Shah, likewise guarantees a sizeable number of the "Basic Rights of the People of Afghanistan." It mirrors many of individual rights protected under the 1923 Constitution. It includes a new provision, Article 23, on limited freedom of the press.

Individual rights occupied an even more prominent position in the 1964 Constitution, which was the first Constitution drafted with public participation, including that of women. Title Three of the 1964 Constitution covers the "Basic Rights and Duties of the People" and includes sixteen articles detailing specific individual rights. Article 25 prohibits discrimination and ensures equal treatment under the law; Article 28 protects the privacy of the home and requires search warrants; Article 29 protects the right to private property and prohibits government seizure of private property without equitable compensation; Article 30 protects privacy of communications while Article 31 protects the freedom of thought and expression; Article 32 assures the right of free assembly; Article 34 confers the right to a free education; and Article 37 promises the right to work and prohibits forced labor. The 1964 Constitution also imposes duties on citizens of Afghanistan. Article 40 requires all citizens to follow the Constitution and laws of Afghanistan; Article 38 requires all citizens of Afghanistan to pay their taxes; and Article 39 requires compulsory military service.

Two rights guaranteed under the 1964 Constitution - the right to form political parties (Article 32) and the unqualified freedom of the press (Article 31)-altered Afghanistan's political landscape. These two rights enabled different groups within Afghanistan to advocate competing political ideologies. Islamic parties, Marxist parties, and Monarchist parties, used their rights under the Constitution to engage in robust political debate during the Constitutional period (1964-1973).

The 1977 Constitution, like its predecessors, contained a chapter on "Rights and Obligations of the People." It enumerated over twenty individual rights and specifically referred to the equality of men and women (Article 27). It also guaranteed the right to vote of all Afghans (Article 29).

\section{ANALYZING LEGAL RIGHTS IN AFGHANISTAN}

Now that we have completed a brief review of Afghanistan's long history of individual rights, it is important discuss concepts related to legal rights as they exist in the present day. This section will explore legal duties, legal remedies, limitations on rights, categories of rights, and how to analyze rights. It will give you the tools necessary to dissect the legal rights enshrined in the 2004 Constitution, to be discussed in Section IV. 


\section{A. Why Legal Rights Matter}

Laws enshrine and protect individual rights. Laws also constrain those wielding public power (e.g., the government) so individuals can enforce their rights against the government as a whole.

Rights must be defensible through various types of remedies. This requires strong and functioning institutions, such as a justice system (including lawyers, courts, police, and police) that is reasonably competent and effective.

Impartiality and fairness of the justice system, especially amongst judges, contributes to the protection of individual rights by insulating them against the corrosive effects of political manipulation or corruption. A system that protects the civil and political rights of the entire population from encroachment by the state apparatus is one defined by the rule of law. The rule of law thus makes possible individual rights, and the benefits they bring.

\section{B. Responsibilities \& Duties}

Legal rights do not exist in a vacuum where individuals benefit from the action or inaction of others without having to undertake certain responsibilities themselves. All rights impose a duty or obligation on someone else. Many duties and obligations belong to the government because it must act or refrain from acting in order to protect a certain right. Individuals themselves also have important duties and obligations in any rights system. Perhaps the most important duty is to respect the rights of others. This duty applies to both government and individuals because, without it, any rights-based system would be impossible.

Chapter Two of the Constitution of Afghanistan, entitled "Fundamental Rights and Duties of Citizens," makes very explicit the linkage between rights and duties. The most basic duty of all citizens of Afghanistan is to obey the Constitution and laws of Afghanistan and the public order. Legal rights would be meaningless without this duty because rights are based on laws that would be ignored instead of obeyed.

Another duty of citizens of Afghanistan is to pay taxes (Article 42). This is very a basic but important duty because the government cannot function without tax revenue. The government will lack the necessary funds to ensure the right of all citizens to an education (Article 43), the right of the indigent defendant to a defense attorney (Article 31), or the right to just compensation for any property seized by the government (Article 40) if individuals do not pay their taxes.

\section{Discussion Questions}

1. Were you aware that the Constitution imposes duties upon you as a citizen of Afghanistan before reading this passage? 
2. Do you think it is fair for the Constitution to impose such obligations on you?

3. Should citizens have more or less duties? Why? What additional duties should they have? Or which duties are unnecessary?

\section{Legal Rights and Remedies}

The vast majority of rights that you will encounter are legal rights. Legal rights are rules established by law about what must or may be done or not done. Legal rights belong to both individuals and institutions. This chapter will focus primarily on individual rights. It is important to remember that the National Assembly's power to legislate, the President's power to enforce the laws, and the Courts' power to adjudicate disputes are legal rights that belong to government institutions and that are protected by the 2004 Constitution.

The legal rights of individuals both protect and limit the liberty and freedom of citizens. For example, the right to life guaranteed under Article 23 of the Constitution limits the freedom of others because they are not allowed to take your life. To do so would violate your rights, and hence, the law. At the same time, institutional rights empower the government to take certain actions and prevent it from taking others. For example, Article 29's prohibition on torture and cruelty limits the methods that the government may employ when interrogating a suspected criminal. Such a prohibition reinforces the individual rights to liberty and human dignity enshrined in Article 24 of the Constitution. Individual and institutional rights structure and justify the legal system of Afghanistan and government as a whole.

Legal rights play a crucial role in society by providing a framework for everyday life and a reference point to determine permissible or impermissible conduct. They are only effective, however, if enforced and protected. A legal right that is routinely violated or ignored may become an aspiration that exists only on paper. Even if rights are routinely enforced, a process is needed to respond to violations of rights.

\section{Remedies for Violations of Legal Rights}

A remedy refers to the process of enforcing a right or preventing or redressing a violation of that right.

Remedies have three basic functions. First, a remedy can either compensate the rightsholder for suffering a violation of her rights or attempt to restore the rights-holder to the position that she was in prior to suffering the rights violation. Second, remedies seek to punish or hold liable those responsible for the rights violation. Finally, remedies function to reaffirm the importance of the right that has been violated by providing incentives for individuals not to violate the right again in the future. 
Legal remedies can be either civil or criminal, depending on the right that has been violated and the nature of the violation. Civil remedies usually respond to less serious behavior or violations of rights. Civil remedies provide monetary or in-kind compensation or restitution. Criminal remedies are tougher and are reserved for more serious rights violations. Criminal remedies can include jail sentences or other forms of severe punishment.

There are three main categories of remedies for rights violations: 1) private remedies under domestic law; 2) public remedies under domestic law; and 3) remedies under international law in domestic courts.

Private remedies under domestic law include private enforcement, judicial review of legislative and executive acts, access to courts, access to information, and administrative justice. This important category of remedies enables individuals to seek redress for a violation of their rights within the domestic legal system. For example, an individual whose rights have been violated by the government could ask a court to review the constitutionality of the government act in question. Or an individual could go to court to bring a suit for damages for the violation she has suffered. These are both examples of private remedies under domestic law.

Public remedies under domestic law include general enforcement by the state or enforcement through a special body. The Afghanistan Independent Human Rights Commission (AIHRC) is a special body that plays an important role in the administrative enforcement of rights in Afghanistan (discussed in greater depth in Section III of this chapter).

There are also remedies under international law in domestic courts. The incorporation of a treaty or customary international law into domestic law also provides individuals additional remedies if their rights have been violated. Afghanistan also has a long history of providing remedies through informal institutions based on local custom, such as shuras or jirgas.

Imagine, for example, that you are a resident of Musa Qala detained by the police during a large-scale sweep for Taliban fighters. When questioned, you deny that you are a member of Taliban or know anything about the location of Taliban fighters in the area. The police do not believe you and repeatedly beat you in violation of Article 29 of the Constitution before releasing you three days later. Your rights have been violated, but what recourse do you have? What remedy should you seek, civil, criminal, or both? From whom should you seek it? Should you complain to the police, the Ministry of Justice, the AIHRC, or all the above? Or would your local shura better remedy your abuse at the hands of the police? These are complex questions that you will be better able to answer after reading Section III on the enforcement of rights in Afghanistan.

\section{Discussion Questions}

1. Why are remedies important? Would legal rights be meaningful without remedies?

2. In your view, which of the three functions of remedies is the most important? 
3. What types of remedies are most common in your province, town, or village? Do you believe these remedies are just?

\section{E. Limitations on Legal Rights}

Limitations commonly exist on legal rights. Many legal rights only exist as long as they do not infringe upon another individual's rights. For example, the right to liberty is not absolute; it is curtailed once it affects the liberty of others (Art. 24). Many rights are expressed in general terms in a Constitution and then developed through more detailed laws. Afghanistan is no exception. Many articles of the Constitutional describe broad rights that are then applied according to relevant "provisions of the law."

Additional limitations may be placed on certain rights under extreme circumstances. In many countries, including Afghanistan, the government may limit certain individual rights during public emergencies or national security situations. The President of Afghanistan may declare a state of emergency for up to two months with the endorsement of the National Assembly (Art. 143). He may suspend certain due process rights (Art. 27), the right to gather and demonstrate (Art. 36), and privacy rights (Art. 37, 38) during a state of emergency with the prior approval of the presidents of the National Assembly and Chief Justice of the Supreme Court (Art. 145). Limitations like these are generally frowned upon given the importance of individuals' rights and the ease with which limitations on rights may be abused by the government.

Some rights are so important and fundamental, such as equality before the law, bodily integrity, and the right to life, that they may not be suspended by the government or waived by individuals who possess them. They may not be waived or suspended under any circumstances because the risk posed by such waiver or limitation is so profound. The motivation for governmental attempts to limit these rights (e.g. during wartime when the nation's very existence is challenged) or an individual's reason for voluntarily waiving them (e.g. to save a family member from punishment) do not outweigh the potential danger posed by restricting the right. Just as the principle of Islamic Republicanism is so central to Afghanistan's system of government that it may not be altered (Art. 147), so too are a handful of the most fundamental individual rights.

\section{F. Categories of Legal Rights: A Hierarchy of Rights?}

There are many different types of legal rights. Two broad categories have already been mentioned above, individual and institutional rights. Individual legal rights include several subcategories, human rights, civil and political rights, and economic and social rights. Section II of this chapter will explore the different sub-categories of individual legal rights by examining specific examples of them protected in the Constitution of Afghanistan. Keep in mind that the categories of rights discussed below are very general and somewhat vague. The categories serve 
no purpose beyond grouping rights based on their similarities. Overlap between categories should be expected.

Many of the most important legal rights, such as the right to life, the right to liberty, and the right to freedom of expression are considered universal human rights. These basic rights belong to every human being in every society everywhere in the world. They belong to every person regardless of sex, age, ethnic origin, birthplace, or wealth. Given their fundamental importance, they are inalienable and inviolable. The Universal Declaration of Human Rights, the International Covenant on Civil and Political Rights (ICCPR), the Constitution of Afghanistan, and other legal instruments protect international human rights. Human rights will be discussed in more depth later in this chapter, when we review the different international human rights treaties to which Afghanistan is party. Many of the most important civil, political, economic, and social rights can also be considered human rights.

The concept of a hierarchy of rights suggests that certain rights are more important than others for Afghanistan's immediate development. In light of Afghanistan's limited resources and fledgling institutions, it is especially important to focus on a subset of the most crucial rights attainable in the short term. Bodily integrity (freedom from physical harm, such as torture), nondiscrimination, and education are three rights that are especially vital for Afghanistan's development and whose enforcement is possible in the coming years.

\section{Discussion Questions}

1. In your view, which rights are most important in Afghanistan? Why?

2. How would your friends or parents answer this question? Would they agree that the rights you have identified are the most important? Why or why not?

3. What factors affect a person's perceptions of which rights matter most?

\section{G. Group-Oriented Rights}

Certain legal rights seek to protect the rights of groups of individuals that share common characteristics. Group-oriented rights usually seek to protect a group from discrimination or mistreatment by a more populous group that may have more political power in a country. Article 53 of the Constitution is an example of group-oriented rights because it provides additional protections for the rights of the elderly and those with disabilities, two distinct and discernible groups that are commonly mistreated.

The protection of minorities is a central feature of human rights. Minority groups are particularly vulnerable to abuse and discrimination by majority groups. Ethnic minority groups are commonly subjected to discrimination and mistreatment. Article 22 of the Constitution prohibits discrimination and ensures that the government treats members of all ethnic groups 
equally. Although women are not always a "minority" in the strictest sense of the term, they are another group that is commonly oppressed. Mistreatment of women is a particular problem in Afghanistan despite the Constitution's prohibition against gender-based discrimination. The protection of minority and gender rights are so important that there are numerous international human rights treaties (many of which Afghanistan has ratified) that specifically protect them. The first case study and scenario in Section II will explore these ideas in more depth.

Group-oriented rights are those rights shared by the largest group in a country --all of its citizens. Some countries guarantee a right to a certain commodity to all of its citizens, something that affects everyone and cannot be subdivided. For example, some countries promise their citizens a healthy environment, free health care, or a right to peace.

\section{H. Dissecting Rights}

It is helpful to think about rights by breaking them down into their component parts. Answering four basic questions (who, what, why, how) is a good way to begin analyzing any right.

First, who possesses the right in question? Rights can apply to many different groups, including children, adults, workers, animals, or even the government.

Second, what action, state of being, or object does the right deal with? Rights can pertain to property, access to a lawyer, freedom of expression, or the exercise of religion, among others. A right can be the entitlement to do something, a positive right, or a prohibition against something being done to you, a negative right. For example, does the right empower you to freely express your opinions (positive right) or prohibit someone else from criticizing you (negative right)?

Third, why does the right holder (the "who" identified in question 1) possess the right? Certain rights derive from moral beliefs, local customs, or the laws of society. For example, the right to life protected by law originated in moral beliefs that every person is entitled not to have his or her life taken by another individual.

Fourth, how is the right affected by the actions of the individual possessing the right? Rights can be inalienable, forfeitable, waivable, or temporary. Answering these four questions every time that you deal with an alleged "right" will help you better understand it and assess its strengths and/or weaknesses.

\section{Discussion Questions}

Article 24 of the 2004 Constitution states, "Liberty is the Natural right of human beings. This right has no limits unless affecting others' freedoms as well as the public interest, which shall be regulated by law. Liberty and human dignity are inviolable. The state shall respect and protect liberty as well as human dignity." With this as background, answer the following questions: 
1. Who possesses the right to liberty? Who must respect it?

2. What does the right entail? Is it a positive or negative right or both?

3. Why do people in Afghanistan possess this right? Why is it a Natural right?

4. How is the right affected by individual behavior? Is it inalienable or regulated by law? How do you reconcile these two concepts?

\section{RIGHTS UNDER THE 2004 CONSTITUTION}

While the protection of individual rights in Afghanistan has improved significantly since the fall of the Taliban, much work remains to be done. Many fundamental rights are guaranteed under the 2004 Constitution, but are not enforced in most provinces. It is important to respect the influence of religion and culture on the protection of individual rights. Both tribal customs and Islam affect public perception of rights and their enforcement. This is most evident from the many informal institutions that commonly resolve disputes (including those involving individual rights) throughout Afghanistan. Acknowledging these realities, however, only highlights the importance of increased enforcement of rights for Afghanistan's future development.

This section will take the basic analytical tools covered in Section I and apply them to modern day Afghanistan. We will focus most heavily on the 2004 Constitution and the rights that it enshrines. This discussion will touch upon all of the rights mentioned in the Constitution, but focus on those that are most salient and attainable in the near term. Our attention will then turn to relevant international norms that are embodied in the various human rights treaties that Afghanistan has ratified. We will then explore the enforcement of rights in Afghanistan and the roles of the different branches of government in this key task.

\section{A. Basic Provisions}

Individual rights are guaranteed throughout the Constitution of Afghanistan. Laws or actions in violation of these rights are invalid because the Constitution is the supreme law of the land. Many rights guaranteed under the Constitution are subject to further clarification by law. A small handful of rights may also be suspended during an official state of emergency.

The Constitution mentions the importance of individual rights on its very first page. Its Preamble emphasizes the importance the rights in Afghanistan. It notes Afghanistan's respect for the Universal Declaration of Human Rights and stresses the importance of "protecting ... human rights, and attaining peoples' freedoms and fundamental rights." The preamble clarifies that rights are critical to Afghanistan's goal of forging a civil society "void of oppression, atrocity, discrimination, as well as violence" and based on the "rule of law, [and] social justice." 
Although the focus of Chapter One of the Constitution is the State, it contains a handful of key articles relating to individual rights. Article 2 declares Islam to be the nation's official religion, but also protects the individual freedom to practice other faiths as long as they do not contravene Islam. Article 3 states, "No law shall contravene the beliefs and provisions of the holy religion of Islam in Afghanistan." The lack of specificity of this Article has caused concern in some circles over its potential reach. Could Article 3 be used to limit the numerous individual rights enumerated elsewhere in the Constitution? It is important to recognize the potential tension between certain individual rights enshrined in Chapter 2 of the Constitution, such as the freedom of expression, and Islam. Yet, Islam has a long tradition of protecting fundamental rights, as discussed above. The absolute and universal nature of Islam's protections of the right to life and right to equality before the law, among others, suggests that Article 3 of the Constitution may be perfectly compatible with other provisions of the Constitution.

Previous constitutions likewise incorporated elements of Islam into their texts by stating that "there shall be no law repugnant to the basic principles of . . . Islam and the other values embodied in this Constitution." Other Muslim majority countries have favored this model since the mid-1970s.

Chapter 2 of the Constitution of Afghanistan of 2004 is appropriately titled, "Fundamental Right and Duties of Citizens." It consists of thirty-eight articles that list many individual rights, many of which will be only briefly touched upon. We will discuss in greater length those rights most attainable in the short term and arguably central to Afghanistan's continued reconstruction.

\section{B. Civil and Political Rights}

Civil rights are legal rights that restrict government action that may affect a protected interest, such as an individual's freedom. Civil rights are often negative rights that prevent invasions of an individual's liberty. Political rights provide an individual with the positive ability to participate in the political process and affect the making of laws. Civil and political rights involve the structure of the government and the distribution of political power. In a democracy, civil and political rights are so closely related that distinctions between them may seem artificial.

For example, freedom of expression and assembly (Articles 34 and 35 of the Constitution) are civil rights that protect an individual's right to gather with like-minded individuals and speak one's mind. These two rights are commonly exercised during election campaigns and to influence the government. They are not only civil rights, but also political rights. Most civil and political rights were enshrined in the International Covenant on Civil and Political Rights (ICCPR), which Afghanistan ratified in 1983.

The many political and civil rights guaranteed by the 2004 Constitution are summarized below in Chart 1 . We will begin with rights relating to dignity, equality, and non-discrimination. Next we will discuss rights involving bodily integrity and security followed by fundamental freedoms. Attention will then turn to rights enabling political participation and then to those connected to residence, citizenship, and nationality. We will then briefly review individual rights 
relating to detention and criminal trial (discussed in length in chapter 4) and wrap up with other miscellaneous civil and political rights.

Please keep in mind that these different categories are used simply for organizational purposes. Many of the rights discussed below are connected to one another and serve many overlapping purposes. 


\section{Chart 1: Civil and Political Rights in Afghanistan}

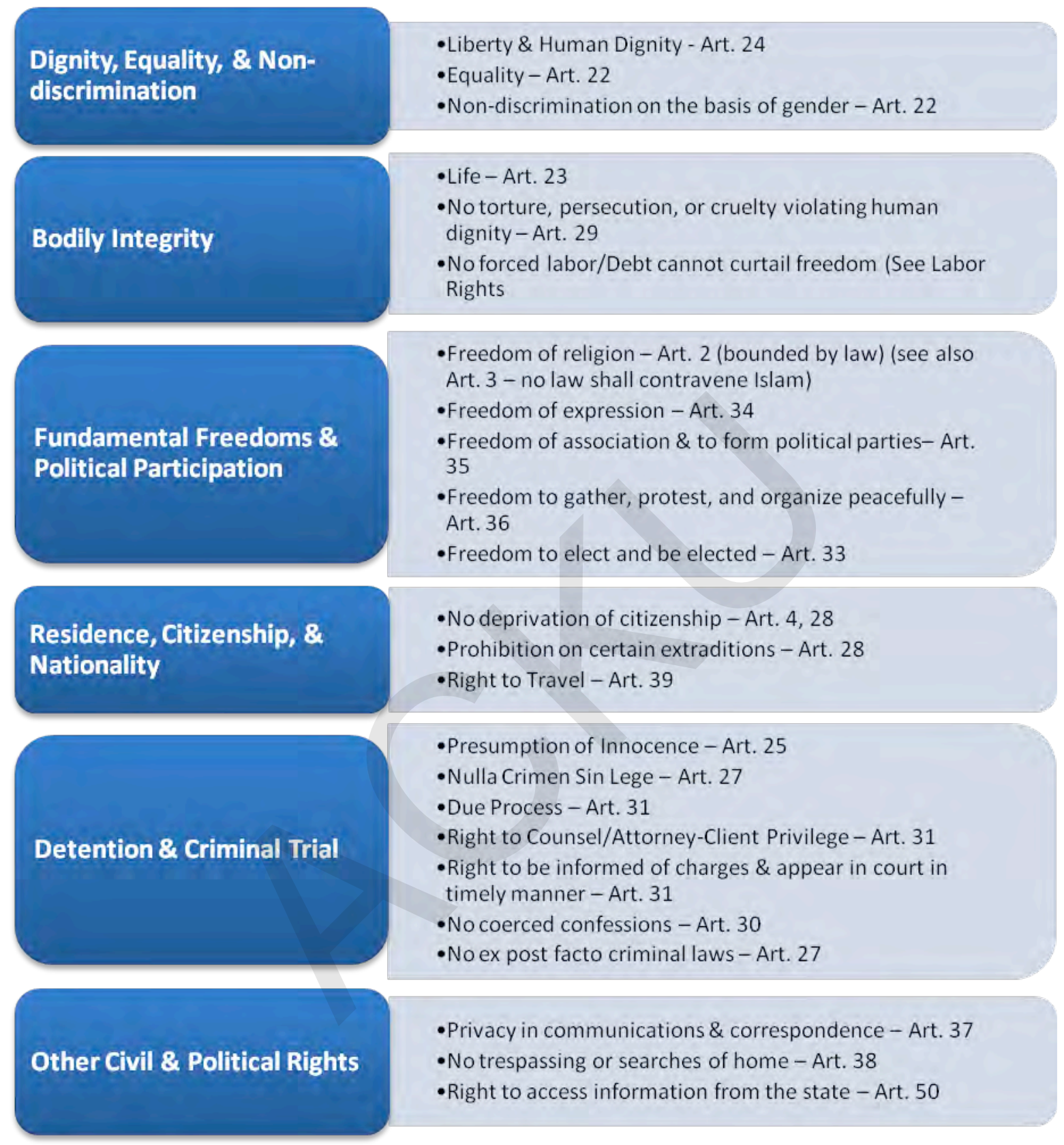

\section{Dignity, Equality, and Non-Discrimination}

Liberty, the right to be free, is one of the most basic of all individual rights and is codified in Article 24 on the Constitution. Article 24 states:

Liberty is the natural right of human beings. The right has no limits unless affecting others['] freedoms as well as the public interest, which shall be 
regulated by law. Liberty and human dignity are inviolable. The state shall respect and protect liberty as well as human dignity.

The strong language reinforces the broad nature of this right, which cannot be limited unless one individual's liberty infringes upon another individual's freedoms. This Article commands the state to protect individual liberty and human dignity. The state may only limit individual liberty if the public interest (as defined by law) so permits. This last phrase seeks to prevent arbitrary government abuse by requiring specific legal criteria to limit individual liberty. Article 24 creates a very strong presumption in favor of individual liberty.

Article 22 embodies two rights of particular relevance to society in Afghanistan, nondiscrimination and equality. It forbids any "discrimination and distinction between citizens of Afghanistan" and affirms that the "citizens of Afghanistan, man and woman, have equal rights and duties before the law." The government must treat all citizens of Afghanistan equally, regardless of religion, tribal affiliation, gender, or age. Pashtuns cannot be treated better than Uzbeks or Turkmen because of ethnic/tribal affiliation; they must all be treated equally. For example, individuals of Hazara descent cannot be arrested by the local police in Mazar-i-Sharif simply because they are not Tajik. These two rights were previously codified in the Constitution of 1964.

The specific mention of "man and woman" in Article 22 draws attention to gender discrimination, especially in rural areas. Denying women equal political and civil rights not only violates the law, but also prevents half of the country's work force and citizenry from contributing to Afghanistan's future. The Constitution makes clear that women cannot be denied an education, healthcare, or due process of law simply because they are women. The trading of women to settle disputes is one vivid example of ongoing gender discrimination in Afghanistan.

The full development of society in Afghanistan is impossible when half of the productive population is denied many of its rights, including the right to judicial recourse. Enforcing Constitutional provisions and laws that guarantee equal rights for women provide double dividends; they directly benefit women and the children they raise, who together make-up a majority of citizens in Afghanistan. Enrollment rates for women at the primary, secondary and tertiary levels are almost half that of men-41.8 percent for females and 73.7 percent for males. Only an estimated 12.6 percent of women are literate, compared to 32.4 percent of men. There is also a large discrepancy in the estimated earned income between females (\$478) and males (\$1428). The following case study, scenario, and questions highlight the seriousness of gender and ethnic discrimination in Afghanistan.

In early 2009, President Karzai signed a draft law regulating the personal affairs of Afghanistan's Shi'ite minority, which constitutes approximately 15 to 20 percent of its population. The international community and Afghan women's groups heavily criticized the law because, in their opinion, it greatly limited women's rights. In response to such criticism, President Karzai promised to review the law and to ensure its compliance with the Constitution. The intensity of the public debate surrounding the law suggests that women's rights will continue to be a delicate, but extremely important issue in Afghanistan's rights discourse. 


\section{Case Study 2: Women \& Politics in Afghanistan}

After thirty years of war and conflict, Afghanistan is slowly moving towards peace and development. This is a very challenging task that requires the help of every citizen of Afghanistan. No country can successfully rebuild and grow without the participation of women. Some individuals believe that politics is the exclusive domain of men and that women have no role. This belief is dangerous because if women do not participate in Afghan politics, the needs of many ordinary citizens, children, and families will not be represented. World Bank studies show that government and businesses run more efficiently and honestly with high rates of female participation.

Women are important to the political life of Afghanistan for many reasons. First, women constitute half of Afghanistan's population. Modern government, especially a democracy, cannot function when a near majority of population does not take part. Women also shape the future of Afghanistan by caring for children, the next generation of citizens of Afghanistan. Mothers who are intelligent, well educated, happy, and healthy are more likely to have children who are intelligent, educated, happy and healthy. Women are often more in tune with daily life and society in Afghanistan. They can make sure that the government understands the problems facing families and children and work to resolve them.

It is not surprising then that over 20 countries currently have women presidents or prime ministers. Women have commonly served as Minister of Foreign Affairs, Minister of Defense, Minister of Education, and Minister of Health throughout the world, including in Muslim countries. Women, such as Shirin Ebadi, have also won the Nobel Peace Prize. A female president, Megawati Sukarnoputri, led Indonesia from 2001 to 2004, while Afghanistan's neighbor Pakistan was led by Prime Minister Benazir Bhutto from 1988-1990 and 1993-1996. Bangladesh was led for almost fifteen years (1991-2006) by two women Prime Ministers, Hasina Wazed and Khaleda Zia.

Women have also played an important role in the formation of Afghanistan's new government. By allocating women a minimum 25 percent of the seats in the Wolesi Jirga of the National Assembly, Afghanistan has taken steps to bring about gender parity in the formal representation of women in decision-making. In August 2011, 69 women serve in the Wolesi Jirga and 28 in the Mesharano Jirga. Women also play a prominent role in regional and local government. For example, the governor of Bamiyan Province, Habiba Surabi, is a woman (Our Country-My Role 2004).

\section{Scenario 1: Ethnic/Gender Discrimination}

Mahbooba and Humaira are close friends whose families live in a small village outside of Jalalabad. They walk to school together every day because their school is 5 kilometers away. They are both excellent students and Humaira is the top student in her class.

One morning during their walk to school, they are approached and threatened by armed men loyal to the local militia commander. The armed men threaten the girls' safety because they believe that girls should not go to school. 
The next day, Mahbooba's older brother, Mohammad Kazim, accompanies the girls to make sure that they safely reach school. When they arrive, the schoolmaster tells them to go home and not to come back. When Mahbooba asks why she and Humaira cannot go to class, she is told that the local militia commander has banned girls at the school.

After returning home in tears, the girls convince their parents to travel to Jalalabad the next day to complain to the government. The mayor expresses his apologies to Mahbooba and Humaira's parents and explains that the real reason their daughters were not allowed to attend school is because they are members of the minority Tajik community not because they are girls. He explains that educational resources are so limited that they will only be spent on Pashtuns.

They leave the mayor's office disgusted and decide to go to Kabul to press their claims. Humaira's parents are particularly eager to resolve this situation because she is eligible for a prestigious government scholarship given to the top student in each class.

\section{Discussion Questions}

1. How would you feel if you were Mahbooba or Humaira? Would you feel differently if you were one of their parents?

2. Is what happened to Mahbooba or Humaira fair?

3. Have you ever been treated differently because of your gender or ethnicity?

4. Have Mahbooba and Humaira's rights been violated? If so, which rights have been violated? By whom?

5. Is the mayor's explanation satisfactory? Does it change anything? Why or why not?

6. How do you think the authorities in Kabul should respond? How do you think that they would respond?

7. Assume that the girls are permitted back to school the next week and that Humaira remains at the top of her class, but is denied the scholarship. It is given to a Pashto boy with lower grades. Is this fair? Have Humaira's rights been violated?

8. What would you have done as the girls' parents?

9. Which type of discrimination do you think is a bigger problem in Afghanistan, gender or ethnic-based discrimination?

\section{Bodily Integrity and Security}

The right to life is guaranteed under Article 23 of the Constitution, which states that life "is the gift of God as well as the natural right of human beings." It goes on to state that no one 
"shall be deprived of [life] except by legal provisions." This basic right provides the basis for criminalizing murder and similar crimes. At the same time, its wording allows the government to pass laws that permit the deprivation of this individual right or legalizes their death. It is likely that the last four words of this provision were included to permit capital punishment (e.g., the death penalty) for serious criminal offenses.

Article 29 is a wide-ranging prohibition against "persecution," "torture," or "punishment" contrary to human dignity. These prohibitions apply even if the motivation for using such measures is to discover the truth "from another individual who is under investigation, arrest, detention, or has been convicted to be punished."

This categorical prohibition also prevents individuals from ordering another person to commit torture or cruel punishment. Torture and abuse by police and other government actors is common in Afghanistan despite this clearly worded protection of individual rights. In fact, the Afghan Independent Human Rights Commission (AIHRC) has documented numerous recent cases of torture. This is troubling given that the 1964 Constitution contained a similar and even more precise prohibition:

No one can torture or issue orders to torture a person even for the sake of discovering facts, even if the person involved is under pursuit, arrest, or detention or is condemned to a sentence. Imposing punishment incompatible with human dignity is not permissible. A statement obtained from an accused or any other person by compulsion is not valid.

\section{Scenario 2: Bodily Integrity \& Security}

The day after he escorts Mahbooba and Humaira to school, Mohammad Kazim is seized by the same armed gunmen that he met the day before. The gunmen take Mohammad Kazim to their base, where their militia commander beats him until he is unconscious. He is tortured for two days before being released.

His family rushes him to the local medical clinic and then reports what happened to the police in Jalalabad. By this time, the AIHRC has opened an investigation into Tajik girls being preventing from attending school. The Commissioner leading the investigation believes (correctly) that Mohammad Kazim's case is related to his investigation. He asks the local police commander to speak to Mohammad Kazim to gather information relevant to his investigation.

The local police commander sends his brother, Inspector Abdul Aziz, to speak to Mohammad Kazim at his home while he is recuperating. Mohammad Kazim refuses to answer the Inspector's questions because he is angry over the local police's inability to protect him or his sister. He is so furious that he spits in the Inspector's face. Abdul Aziz responds by yanking Mohammad Kazim out of bed and dragging him to the police station. He proceeds to hit Mohammad Kazim with a wooden club for the next eight hours until the AIHRC Commissioner becomes aware of the situation and intercedes. 


\section{Discussion Questions}

1. How would you feel as Mohammad Kazim? Is what happened to him fair?

2. Were his rights violated? If so, by whom?

3. Whose conduct is worse, that of the police or local militia commander?

4. Should the AIHRC open a new investigation into police abuse? If you were the AIHRC Commissioner, what would you do?

5. What would you do if you were Mohammad Kazim? The local police commander?

6. What remedies exist to respond to the rights violations described?

\section{Fundamental Freedoms and Political Participation}

Freedom of religion is the first of the fundamental freedoms guaranteed in the Constitution. Article 2 declares "the sacred religion of Islam" the official religion of "the Islamic Republic of Afghanistan." Yet, followers "of other faiths shall be free within the bounds of law in the exercise and performance of their religious rituals." This provision ensures that Christians, Jews, and members of other religions are free to practice their religion in Afghanistan so long as they do not antagonize Islam. The government may regulate the practice of other religions by law, but has not yet done so. Afghanistan's population is 99 percent Muslim, of which approximately 80 percent is Sunni and 19 percent Shi' $a$. Hindus and Sikhs are believed to be the largest religious minorities in Afghanistan, likely outnumbering both Buddhists and Christians.

Freedom of expression, the right to express one's thoughts and ideas, is one of the most basic and fundamental of all rights, and is "inviolable" under Article 34 of the Constitution. All Afghan citizens "have the right to express thoughts through speech, writing, illustrations as well as other means." It is illegal to punish someone for what they say, write, or think. Government censorship is generally prohibited because people in Afghanistan have the right "to print and publish . . . without prior submission to state authorities." These rights seek to jointly promote a free marketplace of ideas where even unpopular views or views that criticize the government are allowed. Conflicts involving freedom of expression are among the most difficult for courts to resolve because they involve a clash of basic values. Scenario 3 below will help you think about these issues.

There are limits on these rights, however. First, the freedom of expression must be "in accordance with provisions of this constitution." This means that freedom of expression cannot violate another provision of the Constitution, such as Article 59's prohibition against undermining the territorial integrity or sovereignty of Afghanistan.

Article 34 also distinguishes between the general rights of the citizenry and those of "press, radio ... television ... publications and other mass media." The government may 
regulate the press and media by establishing standards or issuing permits for them to broadcast within Afghanistan. Similar regulations exist in many countries and normally pertain to the use of certain signal wavelengths and channels to broadcast, as opposed to control over the content of their reporting. The press is regulated by the Press Law, published in March 2002 in Official Gazette No. 800, and the Mass Media law, published in January 2006 in Official Gazette 871. The media law is currently being revised. The new law will likely include a provision very similar to Article 3 of the Constitution.

As highlighted in the introduction to this chapter, the intersection of religion and freedom of expression is very sensitive in Afghanistan. This was very evident in a high profile blasphemy case against a 23-year-old student and journalist in 2007. He was convicted of distributing an article critical of Islam that he had downloaded from the Internet. A court in Mazar-i-Sharif convicted him and imposed a death sentence, which the Meshano Jirga endorsed. Many criticized the legality of the trial because defendant was denied due process and convicted in less than an hour. An Appeals Court in Kabul subsequently commuted the death sentence to 20 years in prison. The student appealed to the Supreme Court, which upheld the sentence. The Supreme Court was criticized, however, for making its ruling in secret. Neither the defendant nor his attorney was permitted to present any argument before the Supreme Court. In fact, they only learned of the ruling (a month after it was made) when they contacted the Supreme Court to submit a brief on behalf of their appeal.

\section{Scenario 3: Freedom of Expression}

Mohammad Kazim's mother, Parisa, is angry about her son's situation and decides to write a letter criticizing the actions of the police, and Inspector Abdul Aziz, in particular. She sends the letter to police commander and to local politicians. After waiting two weeks for a response, she decides to publish the letter as an editorial in the local newspaper. The day after the editorial is published, the police arrive at her house with a summons to appear in court. The police explain that she may go to jail for not submitting the letter for review prior to publication and for criticizing the government. Parisa is also informed that Inspector Abdul Aziz has received numerous death threats since the publication of the editorial.

\section{Discussion Questions}

1. Do you think that Parisa did the right thing? Why or why not?

2. How would you have reacted in her situation?

3. Were her rights violated? If so, how and by whom?

4. Were Inspector Aziz's rights violated? If so, how and by whom?

5. What do you believe should be the limits to freedom of expression? Should they be more strict or lax that those embodied in the Constitution?

6. What are the benefits or dangers of freedom of expression? 
7. What are the benefits or dangers of government censorship?

\section{Case Study 3: Prisoner of Conscience in Eritrea}

Fessahaye Yohannes believes in freedom of expression. In the East African nation of Eritrea, his newspaper and other independent press outlets championed the right to freedom of thought and opinion and provided a forum for critics of the country's increasingly repressive government. The government responded by detaining Fessahaye Yohannes and other leading independent journalists and banning all non-state print media outlets.

Fessahaye Yohannes (pronounced "fess-uh-HIGH yo-HAN-ness"), also known as Joshua, was editor and co-founder of the weekly newspaper Setit, which had at one time the largest circulation of any newspaper in Eritrea. Through its exploration of social issues confronting the country - such as poverty, land and housing concerns, the lack of democracy and justice, and the plight of handicapped war veterans-Setit probed the boundaries of the government's tolerance for alternative viewpoints.

On September 18, 2001, with the world's attention focused on the violent attacks one week earlier in New York and Washington, Eritrean authorities moved swiftly to silence their critics. Police arrested a group of senior officials of the ruling party, whose calls for peaceful political reform had been widely covered by the independent newspapers. The government then shut down all of Eritrea's independent and privately owned newspapers for allegedly "jeopardizing national unity." In the days following, police detained many of the leaders of the independent media.

None of those detained have been taken before a judge, provided legal counsel, or officially charged with an offense. The detained journalists staged a hunger strike in March 2002 to protest their detention. In response, officials transferred the detainees to secret locations. As of 2007, none had been heard from since.

Civil society is severely constrained in Eritrea. The formation of independent nongovernmental organizations (NGOs) is generally not permitted. While the Eritrean Constitution allows for multiple political parties, the democratization process ceased with the onset of Eritrea's 1998-2000 war with Ethiopia.

The only political party currently permitted is the ruling People's Front for Democracy and Justice, and no date has been set for the formation of other parties. Even before banning the independent print media in 2001, the government had refused to allow any independent control of radio or television broadcast media.

Source: Human Rights \& Service Learning: 2007. 
Article 35 of the Constitution guarantees two rights that are fundamental to Afghanistan's democratic system of government: the freedom of association and freedom to form political parties.

Political parties are legal unless: 1) they are based on tenets that contravene Islam or other provisions of the Constitution; 2) are military or quasi-military in nature; 3) are affiliated with foreign political parties; or 4) based on tribal, ethnic, or sectarian affiliation (Art. 35). These limitations seek to ensure Afghanistan's political unity and an inclusive political process where Afghan citizenship is the common political bond.

All political parties must also have transparent organizational structures and finances. No lawfully established political party may be dissolved without the "order of an authoritative court."

All people in Afghanistan also have the right under Article 36 of the Constitution to "gather and hold unarmed demonstrations ...for attaining legitimate or peaceful purposes." This right empowers individuals to communicate their political views and attempt to influence the Government via organized protests. This right is an extension of the freedom of association because it directly protects one of the most basic activities of political parties.

The Political Parties Law, published in Official Gazette No. 812 in October 2003, empowers the Ministry of Justice to register political parties (only those with greater than 700 members). It also details the rights of political parties, such as how they may be funded.

Article 33 is closely related because it guarantees all Afghan citizens the right to vote and be elected. This right empowers people in Afghanistan to shape their government by supporting or opposing specific political parties or politicians. It is a fundamental characteristic of a democratic government because it ensures that the government responds to the will of its constituents, who collectively constitute the source of its power and legitimacy. The AIHRC monitors all Afghan elections to prevent attempts to unfairly influence votes via intimidation or other means or to illegally manipulate election results. Elections are organized in accordance with the Elections Law (2005), Municipal Elections Law (2003), and Provincial Councils Law (2005).

\section{Scenario 4: Political Parties and Voting Rights}

Mohammad Kazim's father, Faraz, is so upset over his son's mistreatment by the local militia commander and police harassment of his wife that he decides to form a new political party to protect minority rights in his province.

He organizes a series of peaceful demonstrations over the next three months to encourage the local government to protect individual rights under the Constitution. His party becomes very popular and soon has over 800 members. His party is so popular that one member creates a website that contains information about the party and describes how it is organized and financed. 
Two weeks before the elections for governor, Inspector Abdul Aziz appears at Faraz's house and informs him that his political party is illegal and has been banned. He shows Faraz an order from the local militia commander authorizing this decision. He further informs Faraz his name will be removed from all ballots and replaced with the name of the local militia commander.

Faraz protests this decision because he feels his rights have been violated. He argues the militia commander's political party is illegal. The election is held as scheduled and the militia commander wins. To make things worse, Faraz is prevented from voting by the police.

\section{Discussion Questions}

1. Is this election fair? Why or why not?

2. Have Faraz's rights been violated? If so, which rights were violated? How were they violated? Who violated them?

3. Is Faraz's party legal? Does this matter? What additional steps could he have taken?

4. Is the militia commander's party legal? Why or why not?

5. If you were Faraz, what would you do?

6. What arguments would you make in court to challenge the election results?

\section{Residence, Citizenship, and Nationality}

Article 4 confers citizenship to all Afghans. Citizenship identifies who is a full-fledged member of a certain country and owes an allegiance to that country, and, in return, is legally entitled to certain rights and privileges provided by the government of that country. Citizenship can be based on residence, heritage, or other requirements, as established by law. It is the basic prerequisite to claiming all of the rights detailed in this chapter. Articles 4 and 28 ensure that no Afghan shall be deprived of her citizenship except as "regulated by law." The Constitution also guarantees the right to "travel and settle in any part of the country" (Art. 39). It also ensures the right of Afghan citizens to travel outside of the country. This right implicates the need for a passport, the issuance of which is governed by the 1939 Law on Passports.

Article 28 also limits the extradition of Afghan citizens to other countries. Extradition is the process whereby a person is forcibly transferred by their own government to a foreign jurisdiction to face prosecution for an alleged violation of that jurisdiction's laws. The government of Afghanistan may only extradite its citizens to countries with which it has signed reciprocity agreements (e.g., they have agreed to extradite their citizens to Afghanistan to stand trial for alleged offenses) and that are party to the same international extradition regimes as it is (Art. 28). 


\section{Detention and Criminal Trial}

The Constitution also codifies numerous individual rights related to detention and criminal trial. These rights are extremely important because they directly control the government's power to punish and deprive an Afghan citizen of her liberty. They will only be very briefly reviewed here because they were examined in much greater depth in chapter 4.

Article 25 establishes the presumption of innocence for all criminal defendants. A person accused of a criminal offense is not guilty until proven so by "order of an authoritative court" (Art. 25). Article 27 embodies the concept of nulla crimen sin lege, that no one may be punished for behavior unless it has been established as a crime under the law, also known as the legal element of a crime under the law of Afghanistan. Ex post facto laws are also prohibited; no one may be punished for an act unless it has been lawfully established as a crime before its commission (Art. 27).

No statement, confession, or testimony may be obtained from the accused or a third party via coercion of any kind (Art. 30). This extends Art. 29's prohibition on torture and violations of human dignity to other, less-severe forms of police or governmental compulsion. Article 30 requires that all confessions must be voluntary and made in front of an authorized court by an accused in a sound state of mind.

Article 31 reinforces Article 27's promise of due process in all stages of the criminal justice process. Due process means that legal proceedings guarantee a basic level of fairness and justice. Due process also stands for the belief that the government must respect all of an individual's legal rights before depriving him of life, liberty, or property.

Article 31 ensures upon arrest, the accused shall "be informed of the nature of the accusation," or receive notice of the charge against him. He also has a right to appear in court in a timely manner.

Article 31 further guarantees everyone the right to counsel either upon arrest or to "prove truth." The state shall appoint defense attorneys for indigent criminal defendants. The attorneyclient privilege protects the "confidentiality of conversations, correspondence, and communications" between the accused and his attorney (Art. 31).

\section{Other Civil and Political Rights}

The 2004 Constitution also enshrines a right to privacy by protecting "freedom and confidentiality of correspondence, as well as communications of individuals" (Art. 37) in addition to stipulating that "personal residences [are] immune from trespassing" (Art. 38). The state may not inspect personal correspondence or communications except as "authorized by law" (Art. 37). It may not search a personal residence without the owner's permission or by a prior order of an authoritative court (e.g., a search warrant) (Art. 38).

In the case of the commission of "an evident crime," however, government officials may search a private residence without a prior court order as long as they promptly obtain such an 
order following the completion of the search. (Art. 38). Both of these rights may be suspended during an official state of emergency. Lastly, Article 50 ensures the right to access government information. This right encourages transparency of government and "has not limit except when harming the rights of others ...[or] public security."

\section{Economic, Social, and Cultural Rights}

Economic, cultural, and social rights ensure general wellbeing by ensuring the provision of basic goods and services to all individuals. These rights differ from civil and political rights because they envision a more active government that provides for basic necessities that sustain individual welfare.

Economic, cultural, and social rights are also different from civil and political rights because they are more aspirational in nature. Even some of the most affluent and stable democracies in the world struggle to provide their citizens with economic and social rights. For example, the United States has been unable to overcome widespread poverty in urban centers and provide adequate healthcare to such communities (see Case Study 4). There are also differences between the institutions required to enforce economic, cultural, and social rights those needed to protect civil and political rights. European practice differs from American practice. The extent to which economic, cultural, and social rights are protected is commonly related to a country's level of development.

For example, the right to healthcare guaranteed under Article 52 of the Constitution is a positive economic right that is fundamentally different from the right against violations of human dignity protected under Article 29. Providing healthcare to all Afghan citizens is a massive government undertaking that requires significant monetary resources. It also requires an efficient Ministry of Health and hospital system to provide health services.

Prohibiting violations of human dignity by the government, on the other hand, requires the government ensure that its agents do not act in a certain manner. Enforcing that negative right requires monitoring compliance with Article 29 as opposed to providing a service to individuals. Instead of providing for negative safeguards against specific government action, economic, cultural, and social rights impose upon the government the obligation to provide desirable goods and services to its citizens.

The economic and social rights enshrined in the 2004 Constitution are summarized below in Chart 2. We will begin with economic rights that focus on property and healthcare. Next, we

will discuss social rights, particularly the right to education as well as rights of children, the elderly, and the handicapped. A discussion of labor rights and cultural rights will follow. 
Chart 2: Economic, Social, and Cultural Rights in Afghanistan
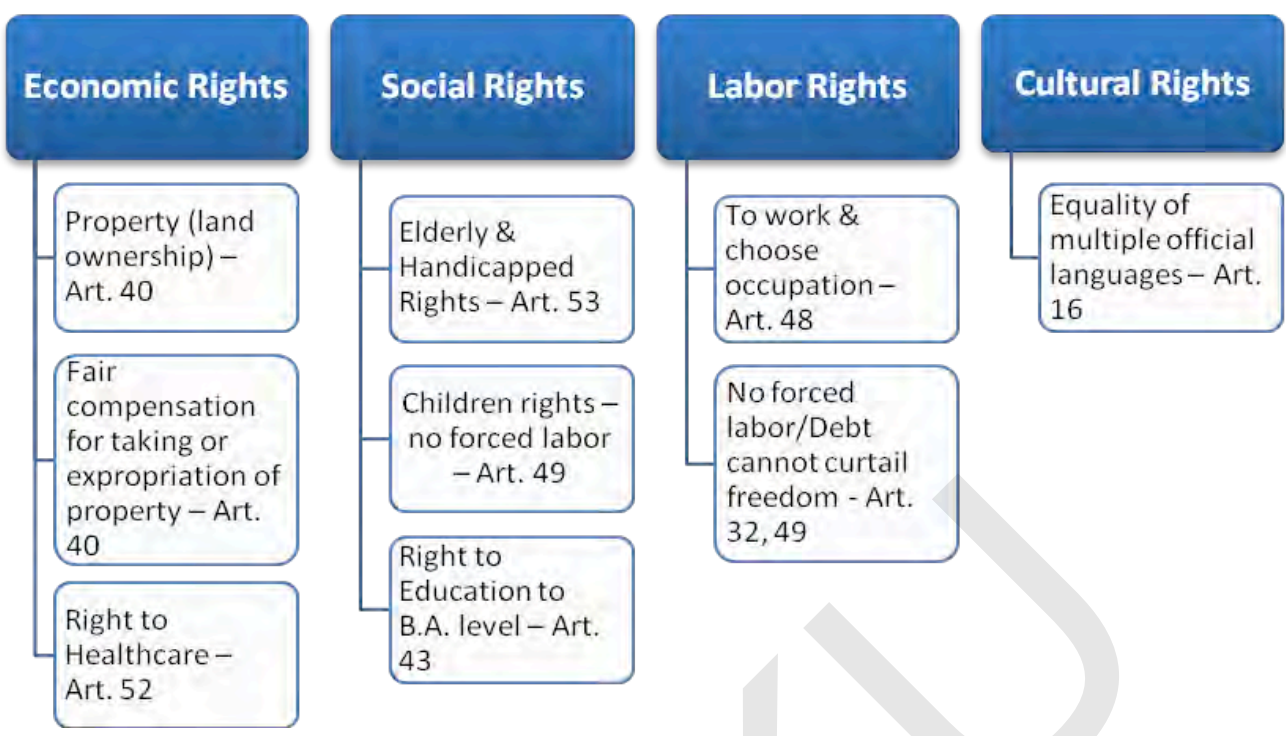

\section{Case Study 4: Poverty in the United States}

Over 3 million men, women and children in the United States are homeless and even more are at risk of becoming homeless. In January 2001, a report by the U.S. Department of Housing and Urban Development (HUD) found that 4.9 million low-income American households had worst case housing needs, spending more than 50 percent of their income on rent, while HUD estimates that families should pay no more than 30 percent. Structural factors exist in society that push people into poverty and homelessness. They include a lack of affordable housing, a lack of employment opportunities, low wages, and cuts in public services and income assistance. Given these conditions, a missed paycheck, a health crisis, or an unpaid bill pushes families in poverty over the edge into homelessness.

Today, fewer than 30 percent of those eligible for low-income housing receive it. According to HUD's January 2001 report, the number of units affordable to low-income households dropped by 1.14 million between 1997 and 1999. Incomes for the poorest Americans have not kept pace with rising housing costs. Millions of workers are shut out of the private housing market. The report by the U.S. Conference of Mayors found that in every state in the US, the minimum wage was not enough for families to afford a one-or two-bedroom apartment using 30 percent of their income, which is the federal definition of affordable housing (Human Rights \& Service Learning 2007). 


\section{Discussion Questions}

1. Were you surprised to learn about the difficulty that the United States has experienced in addressing persistent poverty? Why or why not?

2. Is this case study relevant for Afghanistan's future development? Why or why not?

3. Does this case study provide any insight into the concept of a hierarchy of rights?

4. How does poverty, lack of housing, and lack of healthcare relate to individual rights?

5. Does enforcement of certain rights depend on levels of development? Or are all rights attainable regardless of a country's level of economic development?

\section{Economic Rights}

As highlighted in Chapter 2, the right to own property is central to Afghanistan's development. Article 40 guarantees the right of every Afghan citizen to acquire, own, and sell property. The Government may not confiscate your property except by judicial order according to the law (Art. 40). It may only seize private property in pursuance of the "public interest" and must provide "prior and just compensation" to the owner of any property seized (Art. 40).

Foreigners are prohibited from acquiring "immovable" property and do not share these property rights; they may, however, lease such property for "capital investment" purposes (Art. 41). The Law on Appropriation of Property for the Public Welfare provides greater detail on this legal right.

Article 52 guarantees another crucial economic right to Afghan citizens, access to free healthcare. This right is a clear indication of the belief that the Government is responsible for ensuring the wellbeing of its citizens. The provision of free healthcare imposes upon the Government a massive, resource-intensive obligation predicated upon an efficient Ministry of Health and hospital/clinic system.

This right is aspirational in nature because many people in Afghanistan, especially those living in rural areas, do not yet benefit from free healthcare. In certain areas, the government does not provide health services at all; in others, such services are physically inaccessible due to their distance or remote location; while in others, the quality of healthcare services provided is so low that is not desired.

\section{Discussion Questions}

1. Which economic right is the most important? Why?

2. Which of these rights is the most challenging to guarantee? Why? 
3. If you could create a new economic right, what would it be? Why?

\section{$\underline{\text { Social Rights }}$}

The most basic social right guaranteed by the Constitution is the right to free education. Article 43 states that all Afghan citizens have the right to education up to the undergraduate level provided free of charge by the State. Yet many Afghan children, especially girls, do not regularly attend primary school and end their schooling by the sixth grade.

The primary obstacles to enjoyment of free education are the lack of physical accessibility of schools (e.g., distance too far, lack of security, etc.), the need for children to work instead of go to school (e.g., child labor, economic accessibility, etc.), and child marriage. Articles 43-45 seek to overcome lower rates of school attendance among girls, certain ethnic groups, and nomads by tailoring education based upon language needs, gender, and other cultural traits.

The Constitution also protects the rights of traditionally marginalized social (as opposed to ethnic) groups, such as retirees, the elderly, disabled, handicapped, as well as orphans (Art. 53). Article 53 stresses the importance of the state providing financial assistance to these groups to aid in their "reintegration [into] . . . and active participation in society."

\section{Discussion Questions}

1. Why is the right to education important for Afghanistan's future?

2. Why is it difficult to guarantee?

3. Is you were the Minister of Education what would you do?

4. Now that you know about social rights, would your responses to the questions following Scenario 1 be any different?

\section{Labor Rights}

Article 48 establishes that "[w]ork is the right of every Afghan." This right includes the "choice of occupation and craft" (Art. 48). The Labor Law of 1999, published in Official Gazette No. 790, contains provisions on the rights of workers, requirements for labor contracts, working hours, wages, health and safety standards, work discipline, social security, retirement, and resolution of work-related disputes. Afghan workers have six rights under the law: the right to rest and leave; the right to health and safety; the right to free vocational training; the right to skill-based promotion; the right to participate in the leadership, supervision and production affairs; and, the right to social security. 
The 2004 Constitution also prohibits forced labor (Art. 49). Article 49 states that "forced labor shall be forbidden" and "forced labor on children shall not be allowed." This prohibition is grounded in the belief that every individual is free to control his or her body (e.g. bodily integrity) against undesired outside influences. Forcing another person to work against his will is a violation of individual liberty. Article 32 builds upon this concept and states that "debt shall not curtail or deprive the freedom of the individual." Owing another individual money is not a justification for denying him or her their freedom by, for example, forcing them to labor until their debt has been repaid. Debts can only be recouped as "regulated by law."

\section{Discussion Questions}

1. Which of six rights listed in the Labor Law of 1999 is most important? Why?

2. Which one do you think is most routinely violated? Why?

3. If you could amend the Labor Law to add additional rights, what would those rights be?

\section{Case Study 5: Child Labor in Afghanistan}

Child labor remains a serious problem in Afghanistan. Children under the age of 18 commonly work on farms, as street vendors, carpet weavers, in car repair shops, with blacksmiths and metal workers, and as beggars. Some of these jobs are physically dangerous, while others will result in severe psychological injuries. Children who work are unable to attend school and receive an education. Child labors are also more likely to break the law, become addicted to narcotics, or be physically or sexually abused. Consider the following testimonials about the hardships caused by child labor:

"I am a 13-year-old boy and I have been working cross borders carrying passengers' luggage across Turkham border and being beaten by border guards ever since I was 5 years old. But because I have no father I have to work and I sleep in restaurants at nights and I need to pay in order to sleep there and also work part-time for them and that has been turned into a widespread practice."

"I am a 14-year-boy and working in a home-based soap making industry since I was 9 years old. I am the oldest child in our family and bear all responsibilities at home. I have no complaints about my personal life, but I am sad that I cannot attend school and I am deprived of education."

"I am a 6-year-old boy and together with my 8-year-old brother; work in a fuel retail shop at Qala-e-Zaman Khan. My mother has no plan to send us to school, because since the death of our father we have all the responsibilities at home. We work from 6 am to $8 \mathrm{pm}$ in the shop and suffer from harsh smell of petroleum. When we get home at night we still feel the same smell. During our sleep we suffer from nightmares of beating, insults and ill- treatments." 
"I am a 17-year-old girl and I was forced to carpet weaving at the age of 6 . After my father died, I was the only bread earner of the family. Since the money I earned was not sufficient for the family, my mother had to wash clothes for other families to gain some more money, though she had a small baby at home. At the workplace, I was raped many times by the master and I was transported to Pakistan without knowing and there, I was raped by different persons. After one year of hardships I was transferred back to Afghanistan, but on the way I was arrested and they sent me to Kabul Female Prison. Now I don't know about my destiny and my future is very dark."

"I am a girl who has been working at carpet-weaving industry since the age of 7 and now I am 17 years old. Since that time I used to work from dawn to dusk in order to support my family. I was working very hard to gain more money. During the nights I used to weave carpet at home. At the age of 16 I was totally exhausted. Now I am very nervous, when somebody speaks to me I unwillingly fall into tears. Recently I have been accused of child kidnapping and now I am staying at the correction centre" (Afghanistan Independent Human Rights Commission).

\section{Discussion Questions}

1. Does child labor affect all socio-economic groups in Afghanistan equally?

2. Why is the right against child labor violated?

3. Should the right ever be violated? Under what circumstances? What are the difficulties in enforcing the prohibition on child labor?

4. What would you do if forced to work from a young age in order to provide food or other basic necessities for your family?

5. What are the dangers of child labor?

\section{Scenario 5: Labor Rights}

The day after the election, Inspector Abdul Aziz appears at Faraz's home while he is away. The inspector takes Mahbooba out of the house over Parisa and Mohammed Kazim's strong objections. The inspector explains that he is taking Mahbooba to his sister's house to work as a carpet weaver until she has made enough carpets to pay for the "debt" Parisa owes him. Parisa denies that she owes the Inspector a debt and says that even if she did, the Inspector cannot "kidnap" Mahbooba and force her to work against her will.

Abdul Aziz explains that Parisa's editorial hurt his reputation and caused him emotional distress due to the death threats he received. He also argues that if Mahbooba is old enough to go to school, she is old enough to work.

The next day, Mahbooba arrives at the house of the Inspector's sister where she is immediately put to work weaving carpets. She is forced to work all day long without a single 
break. Two days later, Faraz and Parisa arrive with the local police commander who secures Mahbooba's release.

\section{Discussion Questions}

1. Have Mahbooba's rights been violated? If so, how?

2. Has anyone besides Inspector Abdul Aziz violated her right? Why or why not?

3. Did Parisa owe the Inspector a debt? Why or why not?

4. Are you convinced by Abdul Aziz's arguments about Mahbooba's fitness to work? Why or why not? Does it make a difference if she is only 8 years old? How about 12 or 17 years old?

5. In your opinion, what is the biggest danger posed by child labor? Are there any benefits to this practice?

6. Assuming now that Mahbooba has voluntarily agreed to work for Abdul Aziz's sister, were any of her labor rights violated? If so, how?

\section{Cultural Rights}

Article 4 of the Constitution highlights the many tribes, ethnicities, and cultures that comprise modern-day Afghanistan. The Constitution recognizes cultural rights by guaranteeing the equality of all Afghans under the law (Art. 22) and freedom to practice the faith of one's choice (Art. 2). Article 6 creates an obligation for the government to promote equality "among all peoples and tribes" of Afghanistan, thereby ensuring development in all "areas of the country." Article 16 establishes Pashto and Dari as the two official languages of Afghanistan. In areas of the country where a majority of the population speaks "Uzbeki, Turkmani, Pachaie, Nuristani, Baluchi, or Pamiri," that language will become the third official language of the state (Art. 16). The government must "foster and develop" all of languages spoken in Afghanistan (Art. 16).

\section{Discussion Questions}

1. What is a culture? What is a cultural right?

2. For whom do cultural rights matter most?

3. Why are cultural rights a politically sensitive issue in Afghanistan?

4. Do you think that Afghanistan has more or less cultural diversity than other countries?

5. What are the implications of Article 16 for education in Afghanistan? How does Article 16 affect the functioning of the government bureaucracy? 
6. What are the benefits of the vague language utilized in Article 16 ?

\section{International Human Rights}

Afghan citizens are guaranteed a wide array of human rights by international human agreements. Many of the most basic legal rights, such as the right to life, right to liberty, and freedom of expression, are considered universal human rights that belong to every person in every society in the world. Afghanistan is party to many of the most important international human rights treaties. These instruments comprise a set of standards that form the basis of the United Nations human rights system and are part of international law. Some treaties express more concrete rights (ICCPR) while others express aspirational rights (ICESCR). Many create reporting mechanisms to monitor state compliance.

Article 7 of the Constitution requires the government to "observe the United Nations Charter, inter-state agreements, as well as international treaties that Afghanistan has joined, and the Universal Declaration on Human Rights." The Constitution incorporates international human rights standards into Afghanistan's legal system. Not only must the government protect the rights enshrined in such treaties, but it must also review its laws, policies and practices, to ensure that they, too, are in compliance. The Afghan Independent Human Rights Commissions (AIHRC) (discussed below) is responsible for monitoring compliance with human rights treaties in Afghanistan. The Supreme Court is responsible for reviewing international treaties for "their compliance with the Constitution and ...interpretation according to the law" (Art. 121).

The Universal Declaration of Human Rights, mentioned by name in Article 7 of the Constitution, is not a treaty but a resolution adopted by the United Nations General Assembly in 1948. It lacks the inherent, binding legal force of a treaty, but has over time achieved the status of customary international law. It serves as the foundation of the ICCPR, ICESCR, and all subsequent human rights treaties. Chart 3 summarizes the international human rights treaties that Afghanistan has ratified. It also lists some of the most important provisions of each treaty.

\section{A Brief History of Human Rights}

While human rights have existed for as long as human beings have existed, they have not always been recognized in formal law. Following the death and destruction of World War II, governments recognized the need for an independent institution, which would work to prevent conflicts in the future. They established the United Nations (U.N.).

The primary objective of the U.N. was to promote international peace. The founders of the U.N. recognized that protecting individual rights to life, freedom, basic necessities, and nationality would be critical to fulfilling the organization's mission to maintain peace. A special committee was created and given the responsibility of creating a document that would define these rights. The U.N. Commission on Human Rights subsequently issued the Universal 
Declaration of Human Rights (UDHR). The UDHR provides a comprehensive framework and vision for how human dignity and freedom should be protected. The U.N. Commission on Human Rights produced two additional treaties intended to act as legally binding documents to enforce the UDHR: the International Covenant on Civil and Political Rights (ICCPR) and the International Covenant on Economic, Social and Cultural Rights (ICESCR). Together, these three documents are referred to as the International Bill of Human Rights.

Multiple other human rights declarations and conventions (or treaties) have been created to protect human rights. Topical conventions deal with specific categories of abuses, such as the Convention on the Prevention and Punishment of the Crime of Genocide. Additional conventions have been created to protect disenfranchised groups, including the Convention on the Rights of Migrant Workers and the Members of their Families, and the Convention on the Rights of the Child. Conventions also exist that prohibit general discrimination based on race, occupation, and gender, such as the Convention on the Elimination of all Forms of Discrimination Against Women, and the Convention on the Elimination of all Forms of Racial Discrimination. The 1990 Cairo Declaration was discussed at length in Section II(B).

Once a government ratifies a human rights treaty or convention, it becomes law and needs to be upheld and protected. Unfortunately, when a county, population or person commits a human rights violation it is difficult to punish the violator under the human rights system. In International cases, while international courts exist as an arbitrator and can take action, they are not always effective (Human Rights \& Service Learning 2007). 


\section{Chart 3: International Human Rights Agreements Ratified by Afghanistan}

\section{Universal Declaration of Human Rights- 1948}

- Right to life, liberty and security of person (Art. 3)

- Prohibition on torture or cruel, inhuman or degrading treatment or punishment

(Art. 5)

- Equal protection of the law; no discrimination under the law (Art. 7)

- No one shall be subjected to arbitrary arrest, detention or exile (Art. 9)

- Everyone has the right to freedom of thought, conscience and religion (Art. 18)

\section{International Covenant on Economic, Socíal,} and Cultural Rights (ICESCR) - 1983

- Right of self-determination (Art. 1)

- Equality of men and women to the enjoyment of all rights (Art. 3)

- Right to work; fair wage; safe work conditions (Art. 7)

- Right to adequate standard of living (food, clothing, \& housing) (Art. 11)

- Right to education (Art. 13)

\section{International Covenant on Civil and Political Rights (ICCPR) - 1983}

- No legal distinctions of any kind based on race, colour, sex, language, religion, political or other opinion, national or social origin, property, birth or other status (Art. 2)

- Slavery and the slave-trade in all their forms shall be prohibited (Art. 8)

- No one shall be subjected to arbitrary arrest or detention (Art. 9)

- Right to freedom of expression (art. 19)

- Minorities shall not be denied the right to enjoy their own culture, religion, or language (Art. 27)

\section{Convention Against Torture and Other Cruel or} Degrading Treatment (CAT) - 1987

- Must take effective legislative, administrative, and judicial measures to prevent acts of torture (Art. 2)

- Ensure that all acts of torture are offences under criminal law (Art. 4)

- Systematic review interrogation rules, instructions, methods and practices as well as arrangements for the custody and treatment of persons to prevent torture (Art. 11)

- Ensure prompt and impartial investigation wherever there is reasonable ground to believe that an act of torture was committed (Art. 12)

-All complaints of torture must be promptly and impartially examined (Art. 13) 
International convention on Elimination of all

Forms of Racial Discrimination (CERD) -

1987

- Commitment to eliminate racial discrimination in all its forms (Art. 2)

- Condemn racial segregation and apartheid; prevent, prohibit and eradicate all practices of this nature (Art. 3)

-Assure to everyone effective protection and remedies (Art. 6)

\section{Convention on the Rights of the Child (CRC)}

$-1994$

-All actions concerning the child shall take full account of his or her best interests (Art. 3)

- Respect the rights and responsibilities of parents and the extended family (Art. 5

- Prevent and remedy the kidnapping or retention of children abroad (Art. 11

- Protect the child from all forms of maltreatment (Art. 19)

Optional Protocol on the Sale of Children,

Child Prostitution and Child Pornography -

2002

- Prohibit the sale of children, child prostitution and child pornography (Art. 1

- Criminalize sexual exploitation or forced labor for profit (Art. 3)

\section{Optional Protocol on the Involvement of}

Children in Armed Conflict $=2003$

- Ensure children under the age of 18 years are not compulsorily recruited into the military (Art. 2)

-Armed groups other than the armed forces are prohibited from recruiting or using children during hostilities; the government must take all reasonable measures to enforce this prohibition (Art. 4)

Convention on the Elimination of All Forms of Discrimination Against Women (CEDAW) 2003

- Eliminate discrimination against women in all its forms and ensure equality with mean in all aspects of society (Art. 2)

-Adopt special measures (including legal ones) to accelerate attainment of this goal (Art. 4)

- Suppress all forms of traffic in women and exploitation of prostitution of women (Art. 6)

A treaty is a binding agreement under international law entered into by states or international organizations. A treaty can be between two countries (a bilateral treaty) or between many parties (a multilateral party). Both types of treaties create obligations between the parties to it. Treaties can be thought of as contracts between different states with slightly different remedies for breach. 
Treaties enter into force when countries sign and then ratify them. Signing a treaty does not create a legal obligation to comply with its provisions. It creates an obligation not to act in a manner inconsistent with the treaty's "object and purpose." A state may decide, as a matter of policy, to abide by a treaty it has signed, but is not required to do so. Ratifying a treaty, on the other hand, creates immediate legal obligations to abide by its provisions. The wording of Article 5 of the Constitution appears to create a legal obligation for the government of Afghanistan where none would normally exist because Afghanistan would not normally be required to "abide" by treaties it only has "signed."

Previous Afghan governments ratified many of the human rights treaties we have mentioned. Afghanistan remains bound by such treaties because, under international law, legal obligations generally do not change with a change in government. Afghanistan may, theoretically be able to avoid responsibility for honoring treaties ratified between 1979 and 1989 because of the illegality of the Soviet occupation. This is a moot point, however, because the current Afghan government strongly supports the ICCPR, ICESCR, CAT, and CERD.

\section{Discussion Questions}

1. Why do you believe that International Human Rights standards are part of Afghanistan's legal system?

2. Does this strengthen or weaken Afghanistan's domestic laws?

3. Which of the treaties listed of Chart 5 interests you most? Why?

4. Which do you think is the most important? Why?

\section{E. Duties of Afghan Citizens}

As mentioned previously, chapter 2 of the 2004 Constitution is entitled "Fundamental Rights and Responsibilities." The title highlights that individuals themselves also have important duties and obligations in any rights-based system. Article 56 establishes the most basic duty of all citizens: to obey the Constitution and laws of Afghanistan and the public order. Legal rights would be meaningless without such a duty because they are based on laws that would be ignored instead of obeyed. The duty to obey the law suggests a more basic duty, to know what the law is. This duty is implicit from Article 56's prohibition on recognizing "ignorance of the laws" as a defense at trial. Permitting such a defense would undermine the duty of all people in Afghanistan and would create a perverse incentive for citizens to remain willfully ignorant of Afghan laws.

Another basic duty of citizens is to pay taxes (Article 42). See chapter 3 for a more detailed discussion of taxation within Afghanistan. People in Afghanistan also have a duty to participate "in times of war, disaster, and other situations that threaten public life" (Art. 49). This duty encompasses an obligation to support government efforts via volunteering or other means 
during national crises. This obligation is very similar to the duty of all citizens to "defend the country" (Art. 55).

Further, individuals are prohibited from undermining Afghanistan's territorial integrity, sovereignty, independence, or national unity (Art. 59). This obligation includes not manipulating the rights and liberties protected by the Constitution to act in this manner (Art. 59).

\section{Scenario 6: Duties of Afghan Citizens}

Faraz grows impatient as his court challenge to the election results remains unresolved. He decides to stop paying taxes to protest the government's slow response to his complaints. Three weeks later, torrential rain showers flood a neighboring village. The former militia commander and now governor asks everyone in Faraz's village to help rescue the survivors. Faraz refuses to help because he distrusts the militia commander who he believes stole the governorship from him. After being threatened by the militia commander, Faraz publicly encourages his whole village to follow his example and refuse to help respond to the disaster in the neighboring town. He says that the militia commander (who is now governor) cannot legally do anything. Moreover, he tells everyone to stop paying taxes or follow the laws because the governor is a crook who does not deserve this respect. Faraz is arrested for his actions. He claims that he should be released because he did not know that any of his actions were illegal.

\section{Discussion Questions}

1. Has Faraz violated any of his duties? If so, which ones?

2. Has Faraz violated Article 59 of the Constitution? Which articles would Faraz rely upon to argue that his actions were legal?

3. Should Faraz be forgiven because he was ignorant of the law? Why or why not?

4. Was the militia commander justified in his actions? Why or why not?

\section{RIGHTS ENFORCEMENT IN AFGHANISTAN}

Describing the rights of people in Afghanistan is important, but it is also crucial to discuss the enforcement of rights within Afghanistan to fully appreciate the status of individual rights within the country. Rights matter, but are aspirational unless protected by the power of the state. The enforcement of rights includes remedies for rights violations.

To review, remedies serve three primary functions: 1) to punish or hold liable those responsible for the rights violation; 2) to compensate the right-holder for suffering a violation of her rights or restore her to the position that she was in prior to suffering the rights violation; and, 3) to reaffirm the significance of the right that has been violated by providing incentives for people not to violate the right again in the future. 
In Afghanistan, the Executive branch of government (Ministry of Justice and National Police) and the Judiciary (the Courts) are primarily responsible for the enforcement of individual rights. The Afghan Independent Human Rights Commission (AIHRC) plays an important role, as well. Informal institutions, such as shuras and jirgas, should not be overlooked because they resolve many local disputes that involve violations of individual rights. Lastly, NGOs, International Organizations, and the media provide additional outlets for those seeking remedies to violations of their rights.

\section{Executive and Judicial Branches}

As described in Chapter 1, the executive branch of government is responsible for implementation of Afghanistan's laws, including the Constitution. The Ministry of Justice is in charge of a wide range of the country's legal affairs to ensure that the rule of law is upheld in Afghanistan. Protecting individual rights is among the Ministry's most important duties.

In fact, the Ministry has an entire Department (one of ten) dedicated to the enforcement of rights (Huqooq) and resolution of civil disputes. It focuses on "protecting property rights, labor rights, family rights and other civil rights of the country's citizens." It responds to official complaints made by citizens of Afghanistan, facilitates the adjudication of disputes, and takes measures to implement court decisions involving these rights. It is headquartered in Kabul, but has local offices throughout the country. Its provincial officials serve as gatekeepers in the majority of civil disputes implicating individual rights. This Department, thus, serves an important role in alternate dispute resolution (ADR) involving citizens and government officials. The Huqooq Department and its offices are governed by the Law on Procedure of Obtaining Rights published in Official Gazette No. 786 on August 5, 1999.

The National Police also play an active role in the protection of certain individual rights. As mentioned in Chapter 1, the Ministry of Justice and the President have tasked the National Police with enforcing Afghanistan's criminal laws. Because the police are responsible for investigating criminal offenses, detaining the accused, and ensuring public security, they are most responsible for enforcing rights whose violation constitute criminal (as opposed to civil) offenses. For example, the police are responsible for enforcing the right to life (Art. 23) by preventing murder and protecting individual liberty (Art. 24) by preventing slavery. The police must also respect the limitations placed on government conduct by the Constitution, such as the prohibition against torture (Art. 29), prohibition against coerced confessions (Art. 30), or respect for privacy in personal communications (Art. 37).

The Judiciary decides legal disputes of all types arising under the Constitution and laws of Afghanistan, including those pertaining to individual rights. Primary Courts regularly adjudicate cases where one party is accused of violating the rights of the other. After reviewing the facts of a particular case and the relevant laws, the court issues a binding decision. Depending on the type of right in dispute, this ruling may attempt to remedy the alleged violation. Court decisions can be ultimately appealed to the Supreme Court, as described in Chapter 1. The Government must enforce to the Court's decision through the appropriate government ministry or the National Police. 


\section{Discussion Questions}

1. Why is enforcement of rights important? Why is it so difficult?

2. Why do you think that responsibility for the enforcement of rights is split between two different branches of government?

3. If your rights were violated, who would you approach first, the national police or ministry of justice? Why?

\section{The Afghanistan Independent Human Rights Commission (AIHRC)}

The Constitution of Afghanistan establishes an independent body to monitor and protect human rights, the Afghanistan Independent Human Rights Commission (AIHRC) (Art. 58). The AIHRC consists of nine Commissioners appointed by the President for five-year terms. The Commission has five objectives: 1) monitoring human rights in the country; 2) promoting and protecting human rights; 3) monitoring access to fundamental rights and freedoms; 4) investigating and verifying human rights violations; and 5) taking measures to improve and promote human rights in Afghanistan.

The Commission receives and investigates complaints by citizens of Afghanistan about violations of their human rights. After collecting evidence and analyzing a complaint, the Commission may refer it to judicial authorities or work with other government authorities to address the violation. All judicial organs, ministries, governmental bodies, civil society groups, NGOs, and citizens are legally "obliged" to cooperate with the Commission in achieving its objectives.

Since its creation in 2003, the Commission's Monitoring and Investigation Unit has made numerous visits to prisons and detention facilities throughout the country, monitored human rights during elections, produced and disseminated educational materials on the importance of women's rights, and attempted to investigate abuses by coalition forces.

In 2006, the Commission received 1,645 complaints of which 1,296 were investigated and 192 resolved via referral to government authorities. AIHRC investigations led to the release of nearly one thousand illegally detained and imprisoned men and children. It is limited in its ability to respond to the numerous complaints it receives because it is short-staffed and underresourced. In 2006, the AIHRC investigated three prison wardens in Kabul over an alleged case of a prisoner torturing another prisoner that is still under investigation. As a result of these monitoring efforts, all three prison wardens were dismissed from their duties. In Ghazni province, the AIHRC Monitoring and Investigation Unit looked into a case of torture perpetrated by the police and shared its findings with the Attorney General. The Commission's intervention led to the arrest of several police officers responsible for this act of torture. 


\section{Scenario 7: The AIHRC}

Faraz's wife, Parisa, grows concerned about her husband's behavior and the response of local authorities. She files a complaint with the Afghanistan Independent Human Rights Commission (AIHRC) describing the abuses that her family suffered at the hands of the local militia and police.

A Commissioner dispatched from Kabul investigates the complaint. The Commissioner conducts interviews with Parisa, Faraz, and Mohammad Kazim. Inspector Abdul Aziz refuses to answer her questions. The local militia commander likewise refuses to cooperate because he is angry that he was recently stripped of his governorship after the election results were annulled. She prepares a final report describing the possible violations of rights that have transpired.

\section{Discussion Questions}

1. What should the AIHRC Commissioner's report say? Should it recommend legal action? Which rights violations should it focus on?

2. To which government or judicial authorities should the AIHRC refer its recommendations?

3. Must the Ministry of Justice pursue legal action based on the AIHRC recommendations? If not, should it do so?

4. What other actions should the AIHRC Commission take? How should it respond to Inspector Abdul Aziz's refusal to cooperate?

5. Do you believe that the AIHRC should be independent or report to other government authorities?

6. Should it have fewer or greater powers? If so, which powers should it gain or lose? Why?

\section{Activities of the Afghanistan Independent Human Rights Commission (AIHRC)}

In Herat province, the Human Rights Unit of the AIHRC conducted a workshop on human rights for law enforcement officials. On the second day of the workshop, some participants were absent. They attended the third day of the workshop and justified their absence the previous day by a last-minute raid on thieves that had been located in the province. During the third day of the workshop, the police officers narrated that the day before, they had been told by their superior to beat the arrested thieves. The police officers openly refused and stood to their superior justifying themselves with the human rights principles they had learnt during the first day of the workshop.

During a meeting with the Meshrano Jirga, the Child Rights Unit was informed about the case of a 16-year old girl, who had been trafficked to Pakistan with her disabled husband. The Child Rights unit, with the assistance of a Member of The National Assembly and the IOM office\| 
based in Kabul, was able to track down the location of the young girl in Pakistan. With the help of the IOM office based in Islamabad and the Ministry of Foreign Affairs, the girl was rescued and safely returned to Afghanistan, where she was reunified with her family.

On 13 December 2006, the AIHRC Mazar-i-Sharif regional office contacted the AIHRC Headquarters in Kabul by e-mail and explained its powerlessness in a case involving a person illegally detained in Balkh prison on the order of the Balkh Governor, although the convict was supposed to be released fourteen days before. The efforts of the AIHRC Mazar-i-Sharif in having the detainee released were not effective. The National Human Rights Violations Focal Point discussed this case with the Attorney General in Kabul, who contacted the local attorney in Mazar-i-Sharif, and ordered him to have the illegally detained man released. Within an hour, the Mazar-i-Sharif Regional Office confirmed the successful release of the illegally detained man.

Traditions and customs in Afghanistan can be the cause of violence perpetrated against Afghan women. An example: In July 2006, a woman living in Kabul contacted AIHRC, and showed bruises and marks of beating caused by her husband and in-laws. The Women's Rights Unit initiated a series of mediation meetings with her husband, and discovered that the beating was a way for the husband and the family in law to express their frustration in relation to the common practice of paying a certain sum of money to the bride's family before marriage. Most families get indebted for several years to fulfill the financial requirements implied by a wedding and mostly claimed by the bride's family. The mediation efforts and awareness-raising on women's rights by the WRU resulted in a positive outcome, as eventually violence on the complainant ceased (Annual Report of the Afghanistan Independent Human Rights Commission 2006).

\section{Other Outlets}

Independent accountability mechanisms, such as civil society, human rights groups, and the media, play an important role in monitoring and investigating rights violations in Afghanistan given the limited resources and capacities of the justice system. These outlets are not part of the formal judicial system, but are important vehicles through which to ensure accountability for protecting individual rights in Afghanistan.

Citizens of Afghanistan may turn to domestic or international NGO and civil society groups, such as Amnesty International, International Legal Foundation, the Legal Aid Organization of Afghanistan, or the Afghan Human Rights Organization for legal assistance to seek redress for a violation of their rights. Such groups may be able to provide information and expertise on navigating Afghanistan's legal system to reach the appropriate executive or judicial authorities to address their complaint.

International organizations, such as the monitoring bodies established by international human rights treaties, may accept and/or investigate complaints by individual citizens of Afghanistan of human rights violations. These organizations may be effective despite having no legal power beyond issuing a report or publicly shaming the government.

The media within Afghanistan serves as a powerful tool for preventing individuals and institutions from standing above the law. The media monitor Government activities, and 
therefore, may be an effective vehicle for publicizing a violation of one's rights, or expressing concern over the impact of government policy on one's rights. Given Afghanistan's 85 percent illiteracy rate, the media_primarily radio programming - is an extremely effective means of educating and informing citizens about human rights issues and problems. A recent study indicated that 64 percent of respondents identified media as their most credible source of information about human rights.

Together, the domestic and international media have influenced key policy decision in Afghanistan related to individual rights. For example, in mid-2006, President Karzai's cabinet approved a proposal to reestablish the Department for the Promotion of Virtue and Prevention of Vice. The Department's responsibilities were vague, and the proposal raised concerns that it would reinstate the kinds of extra-judicial punishment the Department had been known for under the Taliban regime. Media outlets reflected the concerns of political leaders, citizens, along with civil society groups who feared the potential abuse of individual rights by the proposed Department. Women, in particular, feared that the Department would slowly limit their access to education and participation in the workforce. One female member of the National Assembly explained, "[t]he Government presents it as a symbolic force today, but there is no guarantee that tomorrow this force does not change to a brutal and religious extremist force, the same as the past." Following publication of hundreds of news articles, radio programs, and television debates, the bill was stopped before making its way to the National Assembly.

\section{CONCLUSION}

This chapter has exposed you to the concept of legal rights. You should now have a better understanding of rights, in general, and how to go about analyzing them. You should also have a better idea of your rights as citizen of Afghanistan, which derive from Afghanistan's cultural traditions, especially Islam.

The Constitution of 2004 enshrines an impressive array of individual rights; it also highlights the nexus between individual rights and duties. Unfortunately, many of these rights are not effectively enforced throughout the country. A central theme of this chapter has been that some rights are more important than others. It is vital to keep this in mind because many of the enforcement challenges facing Afghanistan will likely remain in the short term. Focusing resources and attention on a subset of critical rights that are achievable in the near future is crucial. Bodily integrity (freedom from physical harm, such as torture), non-discrimination, and education are three rights that are especially vital for Afghanistan's development and whose enforcement is possible in the coming years

There were two key questions that you were asked to keep mind when reading this chapter: what rights should exist in Afghanistan and how should they be secured? You are now ready to answer them and think like a lawyer to evaluate two of most fundamental issues facing Afghanistan today. Whether you one day become a judge, a prosecutor, a defense attorney, a police officer, or remain a concerned citizen, there is a role for you in Afghanistan's future. The rights system of Afghanistan faces serious challenges in the coming years, and it will need the voices of active, involved citizens like you to triumph. 


\section{CHAPTER ANNEX: GROUPS EXERCISES \& HOMEWORK ASSIGNMENTS}

\section{ISSUES IN THE NEWS}

The class will be divided into groups of five students. Each group must locate two articles that discuss legal rights. One article must focus on legal rights in a foreign country and the other must focus on legal rights in Afghanistan. Students may use the Internet, print media, or other library resources to locate their articles. An example of the type of article envisioned is included below.

Each group will prepare a summary of their two articles and give a brief, five-minute class presentation. The presentation should discuss why the legal right is in news and what this suggests about the importance of the right in question. Students should also attempt to connect the article about a foreign rights situation to domestic developments in Afghanistan. How is the experience of the foreign country relevant for Afghanistan? Also, each group should discuss what the article on legal rights in Afghanistan says about rights protections in Afghanistan. Are rights adequately protected or is there room for improvement?

Taliban ban TV in Afghan province

13. May 2008, 03:12

By Sayed Salahuddin

KABUL (Reuters) - Taliban insurgents have ordered residents of a province near the capital Kabul to stop watching television, saying the networks were showing un-Islamic programmes, officials and local media said on Tuesday.

The order is the last in a wave of curbs that the resurgent militants have announced in areas they are active. A senior Afghan information ministry official, Najib Manelai, said that dozens of masked men with weapons entered mosques in Logar province at the weekend and threatened residents against watching television "They threatened the people that 'if you do not give up watching televisions, you will face violence," Manelai told Reuters. Media reports quoted residents as saying that the Taliban imposed the ban because TV networks were showing programmes that were "un-Islamic and anti-Afghan culture". Removed from power in 2001, the al Qaeda-backed Taliban who lead a insurgency against the government and foreign forces, could not be reached for comment. But while in power from 1996 until their ouster, the Taliban Islamists had banned television, music and cinema. More than a dozen private TV networks and scores of radio stations have been launched in Afghanistan since their fall.

The information ministry along with security forces was taking action against the Taliban move, minister Manelai said, without giving details. The ban on television programmes in Logar follows demands in recent weeks by a group of religious scholars and the information minister that some private television stations must stop broadcasting several Indian soap operas on religious grounds. But the demand has been largely ignored. The Taliban have in recent months also ordered mobile phones operators to shut down the networks, saying foreign troops were using the phones to track them down. They have also warned girls in several parts of the south and east not to attend schools. 


\section{STATUTORY INTERPRETATION}

Students are to be given the following provision of the Constitution, excerpt of the 2003 Political Parties Law and background document on political party laws. They will be asked to write a two-page interpretation of the statute utilizing legal, logical, normative, moral, and parochial arguments. This interpretation will not be linked to any specific hypothetical situation, but rather is designed to elicit a creative interpretation of the scope of the statute, as it exists on paper. Specific questions may be asked of the students to help guide their interpretive writings.

\section{Article 35}

To attain moral and material goals, the citizens of Afghanistan shall have the right to form associations in accordance with provisions of the law. The people of Afghanistan shall have the right, in accordance with provisions of the law, to form political parties, provided that:

(1) Their manifesto and charter shall not contravene the Holy religion of Islam and principles and values enshrined in this constitution;

(2) Their organizations and financial resources shall be transparent;

(3) They shall not have military or quasi-military aims and organizations; and

(4) They shall not be affiliated with foreign political parties or other sources.

Formation and operation of a party on the basis of tribalism, parochialism, language, as well as religious sectarianism shall not be permitted. A party or association formed according to provisions of the law shall not be dissolved without legal causes and the order of an authoritative court.

\section{Political Parties Law}

\section{Article 2}

In this law, "political party" means an organized society consisting of individuals which undertakes activities for attaining its political objectives, locally and /or nationwide, based on the provisions of this law and its own constitution;

\section{Article 3}

The political system of the State of Afghanistan is based on the principles of democracy and pluralism of political parties.

Article 4

Citizens of Afghanistan of voting age can freely establish a political, irrespective of their ethnicity, race, language, tribe, sex, religion, education, occupation, lineage, assets and palace of residence.

\section{Article 5}

Political parties can function freely on the basis of the provisions of this law and have equal rights and obligations before the law.

\section{Article 6}

Political parties shall not:

pursue objectives that are opposed to the principles of the holy religion Islam; or 
(1) use force, or threaten with, or propagate, the use or force;

(2) incite to ethnic racial, religious or sectarian violence;

(3) create a real danger to the rights and freedom of individuals or intentionally disrupt public order and security;

(4) have military organizations or affiliations with armed forces; or

(5) Receive funds from foreign source.

Article 7

The headquarters and any regional offices of a political party shall be located in Afghanistan. The government shall ensure the security and safety of the political party's offices.

\section{Article 8}

(1) All political parties shall be registered with the Ministry of Justice.

(2) The procedure for registering shall be regulated by separate regulation.

Article 9

The Ministry of Justice shall refuse the registration of political parties which:

(a) Do not fulfill the requirement of Article 6;

(b) Have fewer than 700 members at the time of registration; or

(c) Wish to register under the name of a political party that has already been registered.

Article 12

A registered political party shall enjoy the following rights:

(a) Independent activity;

(b) Permanent or temporary political alliance or coalition with other political parties;

(c) Open and free expression of opinions, both in writing and peaceful assembly;

(d) Establishing an independent publication organ;

(e) Access to the media at the expense of the political party;

(f) Introducing candidates at all elections; and

(g) Other rights in accordance with the aims and duties of a political party as indicated in its constitution.

Article 15

(1) Political parties may receive income from the following sources:

(a) Membership contributions;

(b) Donations by legal persons up to two million Afghani per year;

(c) Income from a party's moveable and immovable property;

(d) Subsidies by the government in connection with elections;

(e) Other contributions by members.

(2) Political parties shall register all its income and deposit it in a bank account.

Article 17

The dissolution of a political party shall not be ordered unless:

(1) The party uses force, or threatens with the use of force or uses force to overthrow the legal order of the country, or the party has a military organization or affiliations with armed forces;

(2) The measures taken under sub-item 1 of this Article are not effective; or 
(3) The party acts against the articles of the constitution or this law.

Article 18

The Supreme Court shall, upon the request of the Ministry of Justice, dissolve a political priority according to the articles of this law.

Article 19

The Supreme Court shall consider a request for dissolution of the political party as a priority matter and in the shortest possible time. The hearings of the Supreme Court shall be open to the public.

Article 20

The leader or the authorized representative of the political party shall have the right to request the council of the Supreme Court to replace the presiding officer or one or more of the judges. If the Council of the Supreme Court considers the request justified, it shall appoint another presiding officer or judge from the member of the Supreme Court.

Article 21

The leader or authorized representative of the political party shall have the right to be heard and to participate in the hearings or the Supreme Court.

Article 22

The Supreme Court shall fully state its reasons when ordering the dissolution of a political party. The order by the court for the dissolution of the political party shall be definite and final, and shall be published by mass media.

\section{Background on Political Parties Laws}

Emerging democracies face a quandary in devising party law: deciding how much governmental authority should be used in regulating parties while parties themselves are meanwhile expected to provide the agendas for citizens to choose among in determining their government. If governments have no laws stating what parties can and cannot do, nations risk ruthless politics with little or no public accountability. Yet if governments enact strict laws specifying how parties should organize, campaign, and operate, nations can discourage or prevent political parties from participating in public affairs. That quandary recalls a familiar question: How much regulation of political parties is "just right" for a society? While practitioners may wish to create opportunities for "just the right kind of party," the moral may be that democracy is not always served when nations enact party law.

There are five main models that reflect different ways in which states have regulated parties: policies that either proscribe, permit, promote, protect, or prescribe parties and party activities. Emerging democracies might wish to consider how older democracies have followed different trajectories in adopting party law, and consider to what extent local factors might condition which model of party regulation best fits their needs. For example, "too much" party law may have a chilling effect on the formation and development of political parties, as well as deterring the creation of political parties. On the other hand, when enacting "too little" party law, governments may result in an excess of minor parties producing chaotic government. These 
points are illustrated through a systematic review of party laws covering 169 polities as well as an analysis of experiences in established democracies.

A political party law concerns political parties and normally seeks: 1) To determine what constitutes a political party. This determination often spawns additional party laws: who qualifies for ballot access, who benefits from public resources (such as subsidies or broadcast media), who participates in the government and how, and so on; 2) To regulate the form of activity in which parties may engage. This umbrella heading covers the raising and spending of funds, campaign activities, issue stands in party platforms or manifestos, and more; 3) To ensure appropriate forms of party organization and behavior. Laws could require parties to elect officers by party members, but a party might prefer to choose them through a party congress. Laws might also demand gender or ethnic equality, or laws might require maintaining party organizations in various national regions. One can imagine other policy goals that nations seek to implement through party law.

Creating a political party is a risky business, and the business analogy is instructive. Political entrepreneurs incur both financial and political costs when starting parties. Beyond risking money, party founders risk the loss of their reputations and even political retaliation. There are other parallels between starting a business and founding a party: Just as comprehensive and detailed government regulations can prevent economic entrepreneurs from starting, building, and growing their businesses, comprehensive and detailed party law can prevent political entrepreneurs from starting, building, and growing parties. Therefore, before drafting party law for a nation in transition to democracy, one should ask: "Are the nation, and its parties, ready for party law?" Elections held in developing nations soon after the end of armed conflict can spawn political parties that are primarily_and sometimes solely_vehicles to provide local elites with access to governing power. Such parties may be little more than a repackaging of the armed groups that fought the original conflict. Governing without parties, however, is not the answer. In that case, political life is dominated exclusively by the elite personalities involved: this is the danger of a 'no-party democracy' such as that embraced in dictatorships.

The experiences of other countries has led some scholars to the conclusions summarized on the next page. 
1. In most advanced democracies, political parties were created and grew strong without being mentioned in national constitutions.

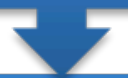

2. Even today, many advanced democracies lack any overarching legislative statute regulating parties in the form of a Party Law.

3. Most advanced democracies that do have a Party Law enacted it after their parties had matured and with the parties' participation.

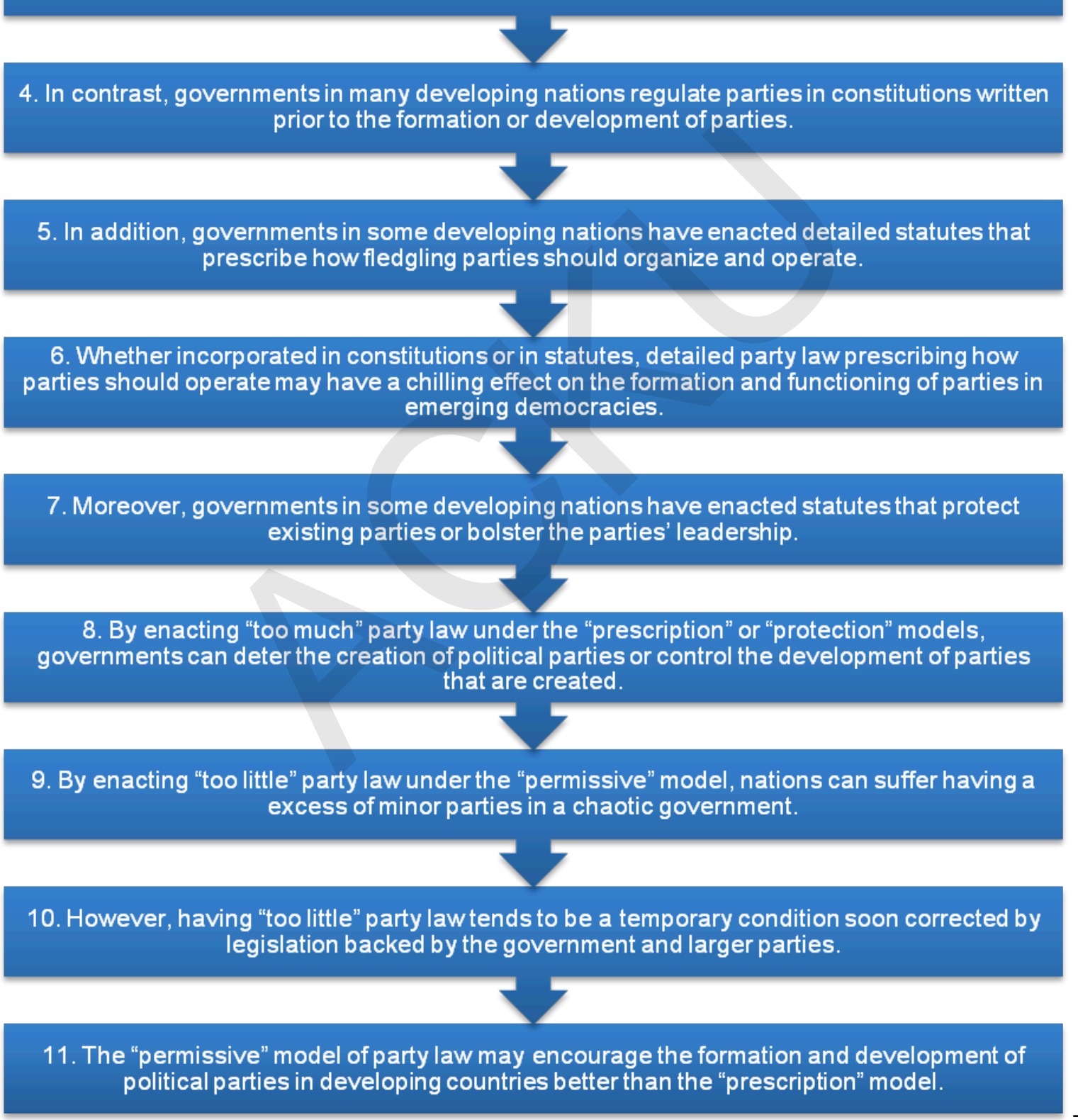

Source: Janda: 2005. 


\section{ADVOCACY EXERCISE}

Recall the facts of the situation described in Scenario 4 on Political Parties and Voting Rights on page 23:

Mohammad Kazim's father, Faraz, is so upset over his son's mistreatment by the local militia commander and police harassment of his wife that he decides to form a new political party to protect minority rights in his province.

He organizes a series of peaceful demonstrations over the next three months to encourage the local government to protect individual rights under the Constitution. His party becomes very popular and soon has over 800 members. His party is so popular that one member creates a website that contains information about the party and describes how it is organized and financed.

Two weeks before the elections for governor, Inspector Abdul Aziz appears at Faraz's house and informs him that his political party is illegal and has been banned. He shows Faraz an order from the local militia commander authorizing this decision. He further informs Faraz that his name will removed from all ballots and replaced with the name of the local militia commander.

Faraz protests this decision because he feels that his rights have been violated. He argues that the militia commander's political party is illegal. The election is held as scheduled and the militia commander wins. To add insult to injury, Faraz is prevented from voting by the police.

Students will be divided in groups of six for an advocacy exercise where each student plays one of the following roles: Mohammad Kazim, his attorney, Ministry of Justice attorney, Chief Justice of the Supreme Court, Supreme Court Justice \#2, and Supreme Court Justice \#3. Assume for the sake of this role-play that the militia commander and Inspector Abdul Aziz have convinced the Ministry of Justice to seek the dissolution of Mr. Kazim's party.

The Chief justice will begin the role-play by briefly summarizing the dispute and highlighting all relevant legal issues. Mohammad Kazim and his attorney will then speak, followed by the Ministry of Justice. After each speaker completes her comments, the Court may ask questions. After everyone has spoken, the three Justices will confer briefly before explaining their decision. Each role's responsibilities are described below in greater detail.

1) Mohammad Kazim- Develop a one-page description of your political party (including its name) that explains its platform, views, and goals. Relay this description orally to the Supreme Court. Make an impassioned plea how your rights have been violated. Consult with your legal counsel to identify the best legal arguments to present. Try to convince the court why the militia commander's party and not yours should be banned.

2) Attorney for Mr. Kazim - Identify the best legal arguments to present to explain how your client's rights have been violated. Attempt to predict the argument of the Ministry of Justice and identify possible flaws or counter arguments. Prepare a five-minute statement to convince the Justices of the merits of your case, including why the election results should be overturned, your client's party legally recognized, and the militia commander's party banned. Pay close attention to the legal requirements of the Political Parties Law and Article 35 of the Constitution.

3) Ministry of Justice Attorney - Review Article 35 of the Constitution and the Political Parties Law and craft a convincing argument why Mr. Kazim's party should be dissolved. Present a five-minute statement to the Court. Take advantage of your speaking order and respond to the arguments made by Mr. Kazim and his attorney. 
4) Chief Justice - Open the hearing by describing the case and relevant legal issues. Ask both parties at least three questions once they have each made their remarks. Guide the deliberations of the Court and strive to reach consensus. Announce the Court's decision.

5) Justices \#2 \& \#3 - Review all of the legal issues in the case and ask each party at least five questions once each has made his or her remarks. Participate in the Court's deliberations.

This exercise may be repeated and students assigned different roles. It is beneficial to play opposing roles and make arguments on both sides of the dispute. 


\section{DRAFTING EXERCISES}

A. Constitution \& Law Re-Drafting - Following the advocacy exercise, each student will re-draft Article 35 of the Constitution as well as the six articles of the Political Parties Law that he or she believes are most problematic. Students are free to choose among any of the provisions listed in Statutory Interpretation Exercise above. The new draft of Article 35 and the six provisions of the Political Parties Law should contain brief explanations of how the new language is an improvement over the old text. Is the new wording more effective, clearer, and/or more concise?

B. AIHRC Complaint- Students must draft a two-page letter to the AIHRC. The letter should describe a rights violation and the proper remedy for the violation. Students should begin browsing one of the recent AIHRC reports by the available at: http://www.aihrc.org.af/reports_eng.htm. The reports contain numerous examples of the types of violations commonly reported in Afghanistan and the typical AIHRC response. Each student's letter should being by describing the hypothetical situation that led to the violation. Next, the student should explain the legal basis for their complaint by identifying the Constitutional or legal provision that has been violated. Lastly, students should identify the type of assistance or remedy they seek from the AIHRC. 


\section{RESEARCH ASSIGNMENTS}

A. The beginning of this chapter asks two key questions: what rights should exist and how should they be protected? Each student should consider both questions and write a five-page essay describing how he or she would revise chapter 2 of the Constitution if given the opportunity. At a minimum, each student should identify those rights and responsibilities that he or she would strengthen, weaken, add or remove. This is not a drafting exercise per se, but rather a deeper exercise requiring broader analysis of the rights and responsibilities of the citizens of Afghanistan.

B. Each student must conduct basic research about legal rights guaranteed to citizens of two foreign countries. The student must then compare the legal rights protected in Afghanistan to the legal rights protected in the other countries. What can Afghanistan learn from these other countries? What can they learn from Afghanistan? This comparative exercise should take the form of an essay that does not exceed six pages in length. One useful resource for this assignment is: http://www.hrcr.org/chart/categories.html. 


\section{RIGHTS CAMPAIGN EXERCISE}

Review Chapter 2 of the Constitution and choose a right that you believe is important for Afghanistan's future and that is not currently protected in the country. Your assignment is to develop an advocacy strategy to promote the protection of this right in Afghanistan. Your advocacy strategy should include legal, political, and public affairs components. That is, you should have a specific strategy to use the legal system, the media, and political process to succeed in your goal. Please conduct the research needed to prepare your advocacy strategy and draft all documents needed to implement it. 


\section{GLOSSARY OF SELECTED TERMS}

Acquitted: The person in whose favor a judgment has been issued.

Appeal: Process for requesting formal review of an official decision.

Attorney General: Head of the saranwal division and representative of the government in criminal cases

Civil procedure: The body of law that sets out the rules and standards that courts follow when adjudicating civil lawsuits.

Constitution: A system of government, which is often codified in a written document that establishes the rules of a political entity

Convicted: The person(s) against whom a judgment has been issued.

Democracy: A system of government based on elections of leaders whereby the people in a state may express their governing preferences

Defendant: The party against whom the claim is filed.

Dewan: The subject specific divisions of the district or appeals court system

Dismissal (judgment of): Decision issued in the absence of proof (of the claim).

Ethics: The legal and moral obligations that guide a lawyer in the exercise of his or her profession.

Experts: Professional persons who have sufficient expertise and experience in specific fields and who testify as witnesses.

Final Appeal: After receiving a judgment from the court of appeals, the parties may present their complaint or objection to the Supreme Court.

Formal legal system: The system of courts, laws, and legal adjudication sponsored by the state and conducted under its supervision.

Judge: A person who issues a judgment.

Judgment (also called "Decision"): Decision issued by the judge through special words, in absolute and definite matter.

Jurisdiction: The power, right, or authority to interpret and apply the law.

Litigation: A controversy before a court, also known as a "lawsuit." 
Plaintiff: The party who is asking the court for relief.

Standard of Review: The amount of deference given by one court (or some other appellate tribunal) in reviewing a decision of a lower court or tribunal. 


\section{Sources Consulted}

1964 Constitution of Afghanistan.

1999 Labor Law of Afghanistan.

2004Constitution of Afghanistan.

2005 Law on the Structure, Duties, and Authorities of the Afghanistan Independent Human

Rights Commission, Article 5, (Official Gazette, Issue No. 855, June 21, 2005).

Afghanistan Independent Human Rights Commission. 2006. "Annual Report."

Afghanistan Independent Human Rights Commission. 2005. "Report on Economic and Social Rights."

Al-Minawi, Kawther M. 2005. Women's Rights in Islam. Riyadh: Ammar Press.

Arthur W. Diamond Law Library at Columbia Law School. "Human \& Constitutional Rights." http://www.hrcr.org.

Cairo Declaration on Human Rights in Islam. 1990. Organization of the Islamic Conference.

Campbell, Tom. 2006. Rights: A Critical Introduction Routledge: 204.

Hassan, Riffat. "Are Human Rights Compatible with Islam: The Issue of the Rights of Women in Muslim Communities." http://www.religiousconsultation.org/hassan2.htm

Henken, Louis et. al. 1999. Human Rights. Foundation.

Janda, Kenneth. 2005. Political Parties and Democracy in Theoretical and Practical Perspectives: Adopting Party Law. National Democratic Institute for International Affairs (NDI).

Jensen, Erik. 2003. The Rule of Law and Judicial Reform: The Political Economy of Diverse Institutional Patterns and Reformers' Responses, in BEYOND COMMON KNOWLEDGE: EMPIRICAL APPROACHES TO THE RULE OF LAW, 336 (Erik Jensen and Thomas Heller eds. 2003).

Mawdudi, Abul A'la. 1980. Human Rights in Islam. The Islamic Foundation.

Ministry of Justice of the Islamic Republic of Afghanistan, http://www.moj.gov.af/

Stanford Encyclopedia of Philosophy. "Rights." http://plato.stanford.edu/entries/rights.

United Nations Development Program (UNDP) and the Government of Afghanistan. 2007.

"Afghanistan Human Development Report 2007: Bridging Modernity and Tradition:

Rule of Law and the Search for Justice.” Kabul University. 